\title{
Geochemistry of deep-sea hydrothermal vent fluids from the Mid-Cayman Rise, Caribbean Sea
}

\author{
by \\ Jill Marie McDermott \\ B.A., Dartmouth College, 2006 \\ M.S., University of New Hampshire, 2009 \\ Submitted in partial fulfillment of the requirements for the degree of \\ Doctor of Philosophy \\ at the \\ MASSACHUSETTS INSTITUTE OF TECHNOLOGY \\ and the \\ WOODS HOLE OCEANOGRAPHIC INSTITUTION
}

February 2015

(C) 2015 Jill Marie McDermott. All rights reserved.

The author hereby grants to MIT and WHOI permission to reproduce and to distribute publicly paper and electronic copies of this thesis document in whole or in part in any medium now known or hereafter created.

Author

Department of Earth, Atmospheric, and Planetary Sciences, MIT \&

Department of Marine Chemistry and Geochemistry, WHOI

September 17, 2014

Certified by

Jeffrey S. Seewald

Thesis Co-Supervisor

Certified by

Christopher R. German

Thesis Co-Supervisor

Accepted by

Elizabeth B. Kujawinski

Chair, Joint Committee for Chemical Oceanography 


\section{GEOCHEMISTRY OF DEEP-SEA HYDROTHERMAL VENT FLUIDS FROM The Mid-Cayman Rise, Caribbean SEa}

by

Jill M. McDermott

\section{THeSIS ABSTRACT}

This thesis examines the controls on organic, inorganic, and volatile species distributions in hydrothermal fluids venting at Von Damm and Piccard, two recently discovered vent fields at the ultraslow spreading Mid-Cayman Rise, Earth's deepest mid-ocean ridge. A wide variety of possible temperatures and substrates for fluid/rock reaction exist at ultraslow spreading ridges. The flux of chemicals delivered to the ocean by circulating vent fluids exerts a major control on mass transfer into and out of the oceanic crust and supports chemosynthetic ecosystems. In Chapter 2, abiotic organic synthesis is shown to occur via two distinct mechanisms in the serpentinizing Von Damm system. Longstanding questions concerning the spatial, temporal, and mechanistic nature of carbon transformations in deep-sea hot springs are addressed. In contrast with the current paradigm, $\mathrm{CH}_{4}$ is not actively forming during circulation of $\mathrm{H}_{2}$-rich vent fluids, but instead is derived from fluid inclusions in the host rocks. Chapters 3 and 4 present in-depth studies of the chemical and isotopic compositions of aqueous species in vent fluids at Von Damm and Piccard to elucidate the role of reaction temperature, pressure, substrate composition, and water/rock mass ratios during the chemical evolution of hydrothermal fluids at oceanic spreading centers. At Von Damm, sequential reaction of gabbroic and peridotite substrates at intermediate temperatures can explain generation of the observed fluids. Geochemical modeling shows that talc-quartz assemblage is expected to precipitate during fluid mixing with seawater at the seafloor. At Piccard, extremely high temperature subsurface water/rock reaction results in high temperature fluids that are richer in dissolved $\mathrm{H}_{2}$ than any previously observed fluids worldwide. At both locations, high- $\mathrm{H}_{2}$ conditions promote the abiotic reduction of $\Sigma \mathrm{CO}_{2}$ to formate species, which may fuel a subsurface biosphere. In Chapter 5, multiple sulfur isotopes were measured on metal sulfide deposits, $\mathrm{S}^{0}$, and fluid $\mathrm{H}_{2} \mathrm{~S}$ to constrain sulfur sources and the isotopic systematics of precipitation in a wide variety of seafloor hydrothermal vents. Areas studied include the eastern Manus Basin and Lau Basin back-arc spreading centers, the unsedimented basalt-hosted Southern East Pacific Rise, and the sediment-hosted Guaymas Basin mid-ocean ridge spreading centers. Limited isotope fractionation between fluid $\mathrm{H}_{2} \mathrm{~S}$ and precipitating chalcopyrite implies that sulfur isotopes in a chimney lining may record past hydrothermal activity.

Thesis Co-supervisor: Dr. Jeffrey S. Seewald Title: Senior Scientist, Woods Hole Oceanographic Institution Thesis Co-supervisor: Dr. Christopher R. German Title: Senior Scientist, Woods Hole Oceanographic Institution 


\section{ACKNOWLEDGEMENTS}

First, I would like to thank my co-advisor, Jeff Seewald, whose limitless scientific creavitity and sunny outlook have been a continual source of encouragement throughout the 5 years of my doctoral education and research. Jeff's gift for simultaneously challenging and motivating me has taught me many lasting lessons. His limitless optimism and imagination have left permanent impressions on my approach to scientific research, and will not be far from mind when I mentor others. I have thoroughly enjoyed being a part of his lab group, where every day is intellectually stimulating and a lot of fun. I would also like to thank my co-advisor, Chris German, whose support has improved my thesis research immensely. Chris introduced me to an excellent team, and together we discovered two new deep-sea hydrothermal systems where I had cautiously hoped to find just one. Chris brims with insight into the broader significance of ocean exploration, and his ability to draw connections between people and idea to plan interdisciplinary projects with new sea-going technology continually surprises and inspires me.

I am grateful to Meg Tivey for her valuable contributions as a committee member, as well as for her support and guidance in all aspects of my life in the Joint Program, both joyful and challenging. My committee member Shuhei Ono has been an integral part of this thesis, and I deeply appreciate Shuhei's efforts to make me feel welcome in his lab group, where I often worked during the first 2 years of my doctoral education. I would also like to thank Frieder Klein, who enthusiastically directed me to find answers to my questions at all hours, and who joined my closed defense in offering questions, suggestions, and dedicated interest that greatly improved this thesis. I also thank Scott Wankel for chairing my thesis defense, and for his help in recording feedback during that critical time.

There are countless persons at WHOI and MIT who facilitated the success of this thesis on a daily basis. I sincerely thank Sean Sylva for his technical expertise, dedication to teaching, and attention to analysis quality. Sean would not simply teach me how to run an instrument, but also made sure I understood exactly how a method works, how to customize it, and how to recreate it again on my own. These skills have proven invaluable during the course of my thesis, and will be even more useful moving forward. In addition, Sean carpools with Sebastion, who is the best dog ever. Numerous collaborators were of assistance on various cruises, and for advice and ideas: Eoghan Reeves, Julie Huber, Julie Reveillaud, Emily Reddington, Andy Solow, Pat Shanks. I thank the captain and crew of the $R / V$ Cape Hatteras, $R / V$ Atlantis, $R / V$ Falkor, and the $H R O V$ Nereus and $R O V$ Jason II teams. James Kinsey kindly provided the maps of Von Damm and Piccard. Mark Kurz assisted with helium isotope analysis, Jurek Blusztajn collected strontium isotope data, and Scot Birdwhistell provided techincal support in the ICP-MS facility. Several Joint Program students have been constant sources of scientific advice, including Arthur Olive, Jesse McNichol, Britta Voss, Carly Buchwald, and Meagan Gonneea. Many thanks are due to the Academic Programs Office staff members who keep the Joint Program running smoothly: Julia Westwater, Lea Fraser, Christine Charette, Meg Tivey, and Jim Yoder. Thanks also to Ronni Schwartz, Mary Elliff, and Ed Boyle at MIT. Sheila Clifford, Donna Mortimer, Mary Murphy, Linda Cannata, and the entire MC\&G administrative staff provides help instantly with a smile, whenever it is needed. The administrative staff at WHOI are fantastic, and make every aspect of the Joint Program more successful and enjoyable. 
My life in the Joint Program has been enriched by many great friends, for whom I am deeply grateful. I am so lucky to have gone through the program with such great people. Thanks to all of you for keping me sane and smiling: Taylor Crockford, Britta Voss, Eoghan Reeves, Ben Linhoff, Arthur Olive, Kalina Gospodinova, Jason Kapit, Amalia Aruda, Albert Almada, Kristin Hunter-Cevera, Carly Buchwald, Liz Drenkard, Ellie Bors, Kathleen Munson, Whitney Bernstein, Cat Monroe, Larry George, Kate Furby, Maria Pascual, Sean Sylva. I am also grateful to my earlier mentors, who inspired me to keep learning, pursue my goal to really understand deep sea vents, and work hard: Karen Von Damm, Marv Lilley, and Dan Fornari.

To my family - my mom Linda, dad Mark, brothers Tom and Tim - my deepest thanks for so many years of love and support. You have been there to listen every time things get hard, and to cheer at my victories, sometimes via live video feed from the ship, while I was trying to sleep. Jeff and Chris are not kidding when they say my mom spent more time on watch than I did! This thesis is your success as much as it is mine. None of this would exist without your love and dedication to me, and I thank you for this. Finally, I cannot possibly express enough thanks to my fiancé Santiago. I am very fortunate to have you there at every step of this degree, and I can't wait to see what we discover next together. You're a true partner in every sense, and we could not have met in a better place.

This thesis research was funded by the National Aeronautics and Space Administration through grant NNX09AB75G and by the National Science Foundation grant OCE-1061863. 


\section{TABLE OF CONTENTS}

$\begin{array}{ll}\text { ABSTRACT } & 3\end{array}$

ACKNOWLEDGEMENTS $\quad 5$

TABLE OF CONTENTS $\quad 7$

LIST OF TABLES 10

LIST OF FIGURES 11

CHAPTER 1. INTROUDUCTION

CHAPTER 2. DisTinCT ABIOTIC SOURCES OF AQUEOUS ORGANIC SPECIES AT THE VON DAMM HYDROTHERMAL FIELD

1. Main Text 30

2. Appendix 46

2.1 Hydrothermal vent fluid sampling and methods 46

2.2 Calculation of endmember compositions 49

2.3 Assessment of $\mathrm{HCOOH}$ metastable equilibrium using chemical affinity

CHAPTER 3. GEOCHEMISTRY OF DEEP-SEA HYDROTHERMAL FLUIDS FROM THE VON DAMM VENT FIELD, Mid-CAYMan Rise, CARIBBEAN SEA 57

1. Introduction 58

2. Geologic setting and description of sampling sites 61

3. Methods 62

3.1 Sample collection $\quad 62$

3.2 Analytical methods $\quad 64$

3.2.1 $\mathrm{pH}$ and volatiles 64

3.2.2 Major and minor elements and metals $\quad 65$

3.2.3 Isotopes 65

3.3 Calculation of endmember fluid compositions 67

4. Results 68

4.1 Non-volatile aqueous species and $\mathrm{pH} \quad 68$

$\begin{array}{ll}4.2 \text { Volatile aqueous species } & 70\end{array}$

4.3 Carbon, sulfur, and strontium stable isotopes 72

5. Discussion 73

$\begin{array}{lll}5.1 & \text { Water-rock reaction } & 74\end{array}$

5.2 Sources of hydrocarbons to Von Damm fluids $\quad 80$

5.2.1 Water-rock ratio estimates 81

5.2.2 Hydrocarbon chemical equilibrium model 84

5.3 Origin of the Von Damm hydrothermal mound 87

6. Summary 90

$\begin{array}{ll}\text { 7. Appendix } & 111\end{array}$

CHAPTER 4. GEOCHEMISTRY OF DEEP-SEA HYDROTHERMAL FLUIDS FROM THE PICCARD VENT FIELD, MID-CAYMAN RISE, CARIBBEAN SEA 129

$\begin{array}{ll}\text { 1. Introduction } & 130\end{array}$ 
2. Geologic setting and description of sampling sites 132

3. Methods 134

3.1 Sample collection 134

3.2 Analytical methods 136

3.2.1 $\mathrm{pH}$ and volatiles 136

3.2.2 Major, minor, and trace element abundances $\quad 137$

3.2.3 Isotopes 137

3.3 Calculation of endmember fluid compositions 140

4. Results 141

4.1 Temperature and $\mathrm{Mg} \quad 141$

$4.2 \mathrm{pH} \quad 142$

4.3 Major and minor dissolved species 143

4.4 Volatile aqueous species 144

4.4.1 Volatiles and carbon species in high-temperature fluids 144

4.4.2 Volatiles and carbon species in mixed, low-temperature fluids 145

4.5 Transition metals 146

4.5.1 Transition metals in high-temperature fluids $\quad 146$

4.5.2 Transition metals in mixed, low-temperature fluids $\quad 147$

5. Discussion 148

5.1 Processes controlling the formation of endmember 'black smoker' fluids 149

5.1.1 Phase separation 149

5.1.2 Quartz equilibrium and fluid $\mathrm{SiO}_{2}$ abundance 150

5.1.3 Effects of fluid/rock reaction on major ion and alkali abundances 151

5.1.4 The effect of high temperature fluid/rock reaction on fluid $\mathrm{H}_{2}$ abundance 154

5.1.5 Effects of fluid/rock reaction on high-temperature fluid $\Sigma \mathrm{H}_{2} \mathrm{~S}$ and metal contents 157

5.2 Processes controlling the formation of mixed, low-temperature fluids 159

5.2.1 The fate of the missing $\mathrm{H}_{2}$ in mixed fluids $\quad 160$

5.3 The origin of hydrocarbons and helium in high-temperature and mixed $\begin{array}{ll}\text { fluids } & 162\end{array}$

5.3.1 Pyrolysis as a source for hydrocarbons in mixed fluids 164

6. Summary

164
165

7. Appendix

183

CHAPTER 5. IDENTIFICATION OF SULFUR SOURCES AND ISOTOPIC EQUILIBRIA IN SUBMARINE HOTSPRINGS USING MULTIPLE SULFUR ISOTOPES 197

1. Introduction 199

2. Sample description 201

3. Analytical methods 202

3.1 Sulfide minerals 202

3.2 Hydrothermal fluids 203

3.3 Isotopic measurements 204 
4. Results 205

5. Discussion 207

$\begin{array}{ll}\text { 5.1 Fractionation during sulfide precipitation } & 207\end{array}$

$\begin{array}{ll}\text { 5.2 Multiple sulfur isotopes applied to natural systems } & 210\end{array}$

$\begin{array}{ll}\text { 5.2.1 Unsedimented mid-ocean ridge } & 211\end{array}$

5.2.2 Back-arc mid ocean ridges 213

$\begin{array}{lll}5.2 .3 & \text { Sedimented mid-ocean ridge } & 217\end{array}$

$\begin{array}{lr}\text { 6. Summary } & 219\end{array}$

$\begin{array}{ll}\text { 7. Appendix } & 237\end{array}$

$\begin{array}{ll}7.1 \text { Basic statistical model } & 237\end{array}$

$\begin{array}{ll}7.2 \text { Error model } & 237\end{array}$

$\begin{array}{ll}7.3 \text { Inference about } \beta & 238\end{array}$

$\begin{array}{ll}7.4 \text { Model sensitivity } & 239\end{array}$

CHAPTER 6. CONCLUDING REMARKS AND FUTURE RESEARCH DIRECTIONS 241 


\section{LIST OF TABLES}

\section{CHAPTER 2}

1. Measured and calculated abundance and stable isotope data for Von

Damm vent fluids 38

A1. Radiocarbon data from Von Damm vent fluids 51

A2. He data from Von Damm vent fluids 52

\section{CHAPTER 3}

1. Measured and calculated endmember inorganic vent fluid compositions at the Von Damm vent field 92

2. Elemental ratios calculated from endmember fluid compositions at the Von Damm vent field 93

3. Measured and calculated carbon species abundances in vent fluids at the Von Damm vent field

4. Measured carbon species $\delta^{13} \mathrm{C}$ values in vent fluids at the Von Damm vent field 95

A1. Measured metal concentrations in the 'dissolved' fraction of Von Damm fluids

A2. Measured metal concentrations in the 'filter' fraction of Von Damm fluids 113

A3. Measured metal concentrations in the 'dregs' fraction of Von Damm fluids 114

\section{CHAPTER 4}

1. Measured and calculated endmember inorganic vent fluid compositions at the $\begin{array}{ll}\text { Piccard vent field } & 166\end{array}$

2. Elemental ratios calculated from endmember fluid compositions at the Piccard $\begin{array}{ll}\text { vent field } & 167\end{array}$

3. Measured and calculated carbon species abundances in vent fluids at the Piccard vent field

4. Measured carbon species $\delta^{13} \mathrm{C}$ and $\Delta^{14} \mathrm{C}$ values in vent fluids at the Piccard vent $\begin{array}{ll}\text { field } & 169\end{array}$

5. He isotope abundance in vent fluids at the Piccard vent field 170

6. Measured and calculated endmember dissolved metal vent fluid compositions at the Piccard vent field

A1. Measured metal concentrations in the 'dissolved' fraction of Piccard fluids 184

A2. Measured metal concentrations in the 'filter' fraction of Piccard fluids 185

A3. Measured metal concentrations in the 'dregs' fraction of Piccard fluids 186

\section{ChAPTER 5}

1. Vent fluids and mineral deposit sample information and chemical compositions

2. Multiple sulfur isotope compositions of modern hydrothermal vent fluid $\mathrm{H}_{2} \mathrm{~S}$, coexisting chalcopyrite and cubic cubanite linings, and acid spring $\mathrm{S}^{0}$ particles and deposits, normalized to VCDT

3. Endmember hydrocarbon abundances and carbon isotopic composition at the Guaymas Basin hydrothermal system in 2003 


\section{LIST OF FIGURES}

\section{ChaPTER 1}

1. Schematic illustration of deep sea hydrothermal vent fluid formation 20

2. Map showing the major sections of the global ridge crest and known locations of active hydrothermal venting

\section{ChaPTER 2}

1. Bathymetry of the Von Damm hydrothermal field and fluid sampling locations

2. Measured $\mathrm{Mg}$ plotted versus $\mathrm{CH}_{4}, \Sigma \mathrm{CO}_{2}, \Sigma \mathrm{HCOOH}$, and $\Sigma \mathrm{CO}_{2}+\Sigma \mathrm{HCOOH}$ for Von Damm fluids

3. Chemical affinity for the production of $\mathrm{HCOO}^{-}$from reduction of $\Sigma \mathrm{CO}_{2}$ by $\mathrm{H}_{2}$ in Von Damm mixed fluids

A1. Measured $\mathrm{Mg}$ plotted versus $\mathrm{H}_{2}, \mathrm{C}_{2} \mathrm{H}_{6}, \mathrm{C}_{3} \mathrm{H}_{8}$, and $\mathrm{Cl}$ for Von Damm fluids 53

A2. Plot of maximum sampled temperature and seafloor pressure conditions at the

Von Damm vent field, and the 2-phase boundary of seawater

\section{CHAPTER 3}

1. Regional map of the Mid-Cayman Rise and map of the Von Damm vent field with fluid sampling locations

2. Measured $\mathrm{Mg}$ plotted versus $\mathrm{SO}_{4}$ and $\mathrm{Cl}$ for Von Damm fluids

3. Measured $\mathrm{Mg}$ plotted versus $\mathrm{Na}, \mathrm{Ca}, \mathrm{K}, \mathrm{SiO}_{2}, \mathrm{Li}$ and $\mathrm{Rb}$ for Von Damm fluids

4. $\quad$ Measured $\mathrm{Mg}$ plotted versus $\mathrm{Fe}, \mathrm{Mn}, \mathrm{Zn}$ and $\mathrm{Cu}$ for Von Damm fluids 99

5. Measured $\mathrm{Mg}$ plotted versus $\mathrm{H}_{2}$ and $\mathrm{H}_{2} \mathrm{~S}$ for Von Damm fluids 100

6. Measured $\mathrm{Mg}$ plotted versus $\Sigma \mathrm{CO}_{2}, \mathrm{CH}_{4}, \mathrm{C}_{2} \mathrm{H}_{6}, \mathrm{C}_{3} \mathrm{H}_{8}, \Sigma \mathrm{C}_{4} \mathrm{H}_{10}$ and $\mathrm{C}_{6} \mathrm{H}_{6}$ for Von Damm fluids

8. Maximum sampled temperature and pressure conditions at Von Damm vent field, plotted relative to the 2-phase boundary. Endmember Von Damm $\mathrm{SiO}_{2}$ contents plotted relative to saturation of quartz in seawater.

9. Plot of estimated $\mathrm{w} / \mathrm{r}$ mass ratios as a function of fluid and rock Sr contents at Von Damm

10. Plot of $f \mathrm{H}_{2}$ variability of a function of temperature for the FMQ and PPM buffers at 500 bar 105

11. Modeled $\mathrm{CH}_{4} / \mathrm{CO}_{2}$ ratios plotted as a function of temperature and redox state

12. Modeled $\mathrm{CH}_{4} / \mathrm{C}_{2} \mathrm{H}_{6}, \mathrm{CH}_{4} / \mathrm{C}_{3} \mathrm{H}_{8}, \mathrm{CH}_{4} / \mathrm{n}-\mathrm{C}_{4} \mathrm{H}_{10}$, and $\mathrm{CH}_{4} / \mathrm{C}_{6} \mathrm{H}_{6}$ ratios plotted as a function of temperature and compared with observed ratios

13. Photomicrographs of Von Damm deposit thin sections 108

14. Results of reaction path modeling for Von Damm fluid-seawater mixing that does not allow mineral preciptation

15. Results of reaction path modeling for Von Damm fluid-seawater mixing that does allow mineral preciptation 


\section{CHAPTER 4}

1. Regional map of the Mid-Cayman Rise and map of the Piccard vent field with $\begin{array}{ll}\text { fluid sampling locations } & 172 \\ & 173\end{array}$

2. Measured $\mathrm{Mg}$ plotted versus $\mathrm{Cl}, \mathrm{SiO}_{2}$, and $\mathrm{SO}_{4}$ for Piccard fluids 173

3. Measured Mg plotted versus $\mathrm{Na}, \mathrm{Ca}, \mathrm{Sr}, \mathrm{K}, \mathrm{Li}$ and $\mathrm{Rb}$ for Piccard fluids 174

4. Measured $\mathrm{Sr} / \mathrm{Mg}$ plotted versus ${ }^{87} \mathrm{Sr} /{ }^{86} \mathrm{Sr}$ for Piccard fluids 175

5. Measured $\mathrm{Mg}$ plotted versus $\mathrm{H}_{2}$ and $\mathrm{H}_{2} \mathrm{~S}$ for Piccard fluids 176

6. Measured $\mathrm{Mg}$ plotted versus $\Sigma \mathrm{CO}_{2}, \mathrm{CH}_{4}, \mathrm{C}_{2} \mathrm{H}_{6}, \mathrm{C}_{3} \mathrm{H}_{8}, \Sigma \mathrm{C}_{4} \mathrm{H}_{10}$ and $\Sigma \mathrm{HCOOH}$ for $\begin{array}{ll}\text { Piccard fluids } & 177\end{array}$

7. Measured $\mathrm{Mg}$ plotted versus $\mathrm{Fe}, \mathrm{Mn}, \mathrm{Zn}$ and $\mathrm{Cu}$ for Piccard fluids 178

8. Measured $\mathrm{Mg}$ plotted versus $\mathrm{Al}, \mathrm{Pb}, \mathrm{Co}$ and $\mathrm{Cd}$ for Piccard fluids 179

9. Maximum sampled temperature and pressure conditions at Piccard vent field, plotted relative to the 2-phase boundary. Endmember Piccard $\mathrm{SiO}_{2}$ contents plotted relative to saturation of quartz in seawater.

10. Plot of estimated $\mathrm{w} / \mathrm{r}$ mass ratios as a function of fluid and rock Sr contents at Piccard

11. Modeled equilibrium fluid $\mathrm{H}_{2}$ contents as a function of temperature and $\mathrm{w} / \mathrm{r}$ ratio at 1000 bar

\section{ChAPTER 5}

1. Plot of $\delta^{34} \mathrm{~S}$ ratios versus $\Delta^{33} \mathrm{~S}$ for $\mathrm{H}_{2} \mathrm{~S}, \mathrm{~S}^{0}$, and corresponding mineral linings from PACMANUS, SuSu Knolls, Lau Basin, SEPR and Guaymas Basin 224

2. Plot of $\delta^{34} \mathrm{~S}_{\mathrm{H} 2 \mathrm{~S}}$ versus $\delta^{34} \mathrm{~S}_{\text {chalcopyrite }}$ for black smoker mineral-solid pairs 225

3. Summary of processes affecting sulfur isotope ratios in black smoker and acidsulfate fluids

4. Plot of $\delta^{34} \mathrm{~S}$ ratios versus $\Delta^{33} \mathrm{~S}$ for $\mathrm{H}_{2} \mathrm{~S}, \mathrm{~S}^{0}$ and chalcopyrite for $\mathrm{SuSu}$ Knolls and DESMOS Caldera, relative to equilibrium sulfur isotope compositions for $\mathrm{H}_{2} \mathrm{~S}$ $\mathrm{SO}_{4}$ and $\mathrm{S}^{0}-\mathrm{SO}_{4}$ expected from magmatic $\mathrm{SO}_{2}$ disproportionation

5. Guaymas Basin fluid $\delta^{34} \mathrm{~S}_{\mathrm{H} 2 \mathrm{~S}}$ plotted versus $\delta 13 \mathrm{C}_{\text {ethane }}$ and versus $\mathrm{CH}_{4} / \mathrm{C}_{2+}$ ratio 


\section{Chapter 1}

\section{Introduction}

Deep-sea hot springs form when circulating seawater extracts heat and chemicals from fractured rock overlying a heat source. The buoyant fluids rise through permeable igneous crust until their expression at the seafloor as a hot, chemically altered vent fluid (Fig. 1). This fluid is replaced by more downwelling seawater, forming a convective circulation cell. Hydrothermal fluid circulation imparts a major control on heat and mass transfer into and out of the oceanic crust. During convection, oxic seawater undergoes high pressure, high temperature water/rock reaction and is transformed into a reducing, $\mathrm{Mg}$ - and $\mathrm{SO}_{4}$-poor fluid that is rich in reduced carbon and sulfur species (e.g., see review by German and SeYfried, 2014). Chemical disequilibria that arise from mixing between reduced species in hydrothermal fluids and oxidized species in seawater support microbial ecosystems in the subseafloor, in the immediate vicinity of the vent field, and in the dispersing hydrothermal plumes (JANNASCH and MotTL, 1985; SHOCK et al., 1995; KARL, 1995). Hydrothermal fluids can be acidic or alkaline, depending on the temperature and pressure conditions of water-rock reaction, relative water/rock mass ratio, and substrate type (MotTl and Holland, 1978; SeYFried and BisCHOFF, 1981; KLeIN et al., 2009; MCCOLLOM and BACH, 2009). Mineral deposits containing metal sulfides may precipitate upon fluid cooling and mixing with seawater. As a consequence of their strong redox and temperature 
contrasts with cold ambient seawater, deep-sea hot springs are energy-rich, protected environments that have been invoked as a possible setting for the emergence of life on Earth (e.g., BAross, J.A. and HoffmAn, S.E., 1985; MARTin et al., 2008; Russell et al., 2010).

Hydrothermal vents are found in every ocean basin along the $\sim 55,000 \mathrm{~km}$ global midocean ridge (MOR) system, the largest continuous geologic feature on Earth (Fig. 2). Ultraslow MORs ( $<20 \mathrm{~mm} \mathrm{yr}^{-1}$ full spreading rate) constitute approximately one quarter of the total ridge length (Dick et al., 2003; SinHA and Evans, 2004). Once considered an unlikely setting for hydrothermal circulation due to low crustal production rates and presumed low magmatic heat availability relative to fast spreading ridges, it is now recognized that the spatial frequency of vents at ultraslow spreading ridges is higher than predictions based on the availability of magmatic heat (BAKER et al., 1996; BAKER and GERMAN, 2004). Ultraslow spreading ridges are now thought to be more efficient at supporting hydrothermal venting than fast spreading ridges (BAKER et al., 2004). BAKER et al. (2004) propose that this higher efficiency may be attributed to mining of heat derived from hot rock, focusing of magma at volcanic centers, and/or exothermic serpentinization reactions that are independent of a magmatic heat source. The specific nature of the heat sources driving fluid circulation in slow and ultraslow systems remains of intense interest (GERMAN and LIN, 2013; LOWELL, 2013).

Ultraslow spreading systems are characterized by deep rift valleys and exposure of mantle-derived materials (DICK et al., 2003). It is thought that their variable depths and hostrock lithologies produce a rich diversity of vent types, comparable to the variety hosted by slowspreading ridges. Towed sensor surveys throughout the 1980s and 1990s have identified pervasive high $\mathrm{CH}_{4} / \mathrm{Mn}$ ratios in advecting hydrothermal plumes along the Mid-Atlantic Ridge (MAR, Bougault et Al., 1998; Charlou et Al., 1988; Charlou et Al., 1998). These high 
$\mathrm{CH}_{4} / \mathrm{Mn}$ ratios are thought to result from hydrothermal fluid-driven serpentinization of ultramafic rocks (peridotite) occurring at lower temperatures beneath the seafloor. Although these high $\mathrm{CH}_{4}$ vent systems are likely to impart important effects on ocean chemistry, such vents have proved challenging to locate using traditional in situ sensing techniques due to the low particulate content of their plumes. Few vents at ultraslow spreading mid-ocean ridges have been sampled and chemically characterized, but they likely play an important, little-understood role in chemical cycling throughout the ocean.

Since the discovery of deep sea hot springs in the Galapagos Spreading Center in 1977 (CoRLISS et al., 1979), our understanding of the chemical controls on key characteristics of hydrothermal fluids such as redox, $\mathrm{pH}$, and the mobility of inorganic species such as dissolved metals, has progressed greatly (e.g., ALLEN and SeYfRIED, 2003; KLEIN et al., 2013; MCCollom and Bach, 2009; Seewald and Seyfried, 1990; Seyfried, 1987; Seyfried and Ding, 1995; VON DAMM, 1995). Pressure and temperature conditions exert an important control on the nature of hydrothermal water/rock reactions. The maximum temperature attainable by a hydrothermal fluid may be limited by the two-phase boundary of seawater. Due to the pressure and temperature dependence of the two-phase boundary (BISCHOFF and ROSENBAUER, 1985), it is thought that pressure exerts on important control on the maximum temperature of circulating fluids. Many hydrothermal systems in the Pacific and Atlantic Oceans vent at seafloor depths shallower than $3000 \mathrm{~m}$ (corresponding to 300 bar), and percolate to depths of $\sim 1000$ to $3000 \mathrm{~m}$ within the crust, thereby constraining the upper limit on fluid temperatures to $\sim 400^{\circ} \mathrm{C}$, assuming hydrostatic pressure in subseafloor environments. The temperature of the two-phase boundary increases with increasing pressure. Thus, exploration of hydrothermal activity in deeper systems is of relevance due to the possibility for higher temperatures of fluid/rock reaction, and the novel 
fluid chemistry that may result.

This thesis examines the processes controlling organic, inorganic, and dissolved volatile distributions in hydrothermal fluids at ultraslow spreading systems, and the effect of high temperatures on fluid chemistry and the transport of metals, organic compounds, gases, and other species in submarine hot springs. The origin of $\mathrm{CH}_{4}$ and other reduced carbon compounds in hydrothermal systems is a topic of great interest to marine chemists, microbiologists, and origin of life researchers. These areas of inquiry are investigated through an in-depth study of the inorganic, organic, and volatile geochemistry of two recently discovered vent systems located on the Mid-Cayman Rise (MCR) (CONNELly et al., 2012; GERMAN et al., 2010), Earth's deepest and slowest spreading MOR $(<15 \mathrm{~mm} / \mathrm{yr}$, ROSENCRANTZ et al., 1988).

CHAPTER 2 and CHAPTER 3 describe the controls on fluid chemistry at the Von Damm vent field, a relatively shallow (2300 m) hydrocarbon-rich, particle-poor, intermediatetemperature vent field located atop an oceanic core complex at the MCR. Von Damm fluids are very rich in dissolved $\mathrm{H}_{2}$ and $\mathrm{CH}_{4}$, reflecting the influence of active serpentinization within the system. Warm $\mathrm{H}_{2}$-rich fluids, such as those emanating from the serpentinizing Von Damm system, create favorable thermodynamic conditions for the abiotic reduction of oxidized single carbon compounds $\left(\mathrm{CO}_{2}\right.$ or $\left.\mathrm{CO}\right)$ to $\mathrm{CH}_{4}$ and other organic species (SEEWALD et al., 2006; SHOCK, 1990, 1992). The origin of high $\mathrm{CH}_{4}$ content in vents has been of interest since the discovery of seafloor hydrothermal systems (CoRLiss et al., 1979; WeLHAN, 1988). Although there is increasing evidence that supports an abiotic origin for $\mathrm{CH}_{4}$ and other low-molecular weight organic compounds in ultramafic-hosted hydrothermal systems (CHARLOU et al., 2002; CHARLOU et al., 2010; ProskUROWSKI et al., 2008), the physical conditions, reaction pathways, and timescales that support abiotic organic synthesis at oceanic spreading centers remain elusive. 
In CHAPTER 2, the reaction pathways of abiotic organic synthesis in an active deep-sea hot spring are constrained. Results show that different organic compounds are produced abiotically in distinct locations within the oceanic crust over a broad range of timescales. The timescales of carbon species transformations in a natural system - thus far primarily investigated using experiments (e.g., BERNDT et al., 1996; HoRITA and BERNDT, 1999; MCCOLlOM and Seewald, 2001; McCollom, 2003a; McCollom, 2003b; Foustoukos et al., 2004; SeEwald et al., 2006) - are identified and show that, in a single system, reaction timescales range from hours to days to thousands of years.

The chemical and isotopic composition of vent fluids at the Von Damm vent field are examined in detail in CHAPTER 3 to further elucidate the role of substrate composition and deep fluid circulation conditions in controlling the abundance of organic, inorganic, and dissolved volatile species. Inorganic considerations support plutonic hosted, high-carbon, high- $\mathrm{H}_{2}$, gas inclusions as the source for the abundant dissolved hydrocarbons (Fig. 1). These results contrast with other working models for the formation of abiotic $\mathrm{CH}_{4}$ and other hydrocarbons in vent fluids that involve the reduction of $\Sigma \mathrm{CO}_{2}$ and/or $\mathrm{CO}$ via Fischer-Tropsch-type processes during active circulation of seawater-derived hydrothermal fluids that are highly enriched in dissolved $\mathrm{H}_{2}$. A gas inclusion hydrocarbon source is also supported by chemical equilibrium modeling that matches observed $\mathrm{CH}_{4} / \mathrm{C}_{2+}$ ratios at conditions that reflect the physical and chemical conditions expected for a fluid inclusion environment. Although modern and Hadean seawater are chemically distinct (e.g., modern seawater is $\mathrm{SO}_{4}$ and $\mathrm{O}_{2}$-rich), modern deep-sea high- $\mathrm{H}_{2}$ hydrothermal environments like Von Damm represent our best natural analogues for early prebiotic Earth conditions. CHAPTER 2 and CHAPTER 3 constrain the importance of abiotic organic synthesis to fluid carbon budgets in an effort to improve our understanding of carbon 
cycling within seafloor and plume ecosystems. Finally, in CHAPTER 3, geochemical modeling indicates that mixing between Von Damm vent fluids and seawater should result in precipitation of the talc and $\mathrm{SiO}_{2}$ minerals that have been observed associated with active venting at the site (HodGKINSON et al., 2012; M.K. Tivey and F. Klein, pers. comm.).

The Piccard vent field is the world's deepest mid-ocean ridge hydrothermal system discovered to date ( $4960 \mathrm{~m}$ ), and is located $20 \mathrm{~km}$ to the NE of Von Damm on basaltic substrate in the neovolcanic zone of the spreading center (KINSEY and GERMAN, 2013). ChAPTER 4 presents detailed chemical and isotopic investigations that examine the effects of extreme pressure on water-rock reaction conditions in high temperature 'black smoker' vent fluids and consequences for lower temperature mixed 'diffuse' fluids at Piccard. The hottest vent fluids measured at the seafloor to date were actively phase separating at $407^{\circ} \mathrm{C}$ and $2990 \mathrm{~m}$ depth at the basalt-hosted Turtle Pits field on the Southern Mid-Atlantic Ridge (HAASE et al., 2007; KOSCHINSKY et al., 2008). Due to its greater depth, the two-phase boundary at the seafloor of the Piccard system is $483^{\circ} \mathrm{C}$ (Bischoff and Rosenbauer, 1988). Although fluids at Piccard vent at temperatures $\leq 398^{\circ} \mathrm{C}$, observations suggest that supercritical phase separation has occurred, potentially at temperatures $>500^{\circ} \mathrm{C}$ in the subsurface. Results of geochemical equilibrium modelling in this study support the hypothesis that the high pressures and temperatures of water-rock reaction during circulation at Piccard result in the novel high- $\mathrm{H}_{2}$ fluid geochemistry that has not been previously observed in basalt hosted systems.

Temperatures in diffuse fluids venting at Piccard range from 45 to $149^{\circ} \mathrm{C}$ and span the abiotic-biotic boundary, as the current known temperature limit for life is $122^{\circ} \mathrm{C}$ (TAKAI et al., 2008). These fluids are derived from mixing between the hot source, or 'endmember' vent fluid and seawater in the subsurface (Fig. 1). Geochemical analysis of mixed fluids provides an 
opportunity to examine the effects of abiotic, biotic and thermogenic reactions in mixing zones of hydrothermal systems.

As the subsurface of active hydrothermal systems is rarely accessible to direct observation, inferences from vent fluid and mineral deposit chemistry are an important means of characterizing processes occurring in the shallow subsurface and at depth. In particular, the sulfur isotope signatures of hydrothermal vent fluids and associated mineral deposits can be used to identify sulfur sources and examine metal sulfide mineral precipitation processes in active deep sea hydrothermal systems. In CHAPTER 5, multiple sulfur isotopes were measured on metal sulfide deposits, elemental sulfur, and fluid hydrogen sulfide to constrain sulfur sources and the isotopic systematics of precipitation in a spectrum of seafloor hydrothermal vents. Areas studied include the eastern Manus Basin and Lau Basin back-arc spreading centers, the unsedimented basalt-hosted Southern East Pacific Rise, and sediment-hosted Guaymas Basin mid-ocean ridge spreading centers. The inclusion of the minor ${ }^{33} \mathrm{~S}$ isotope in CHAPTER 5 provides additional information that differentiates between sediment and magmatic sulfur sources that would otherwise be indistinguishable based on $\delta^{34} \mathrm{~S}$ signatures alone. 


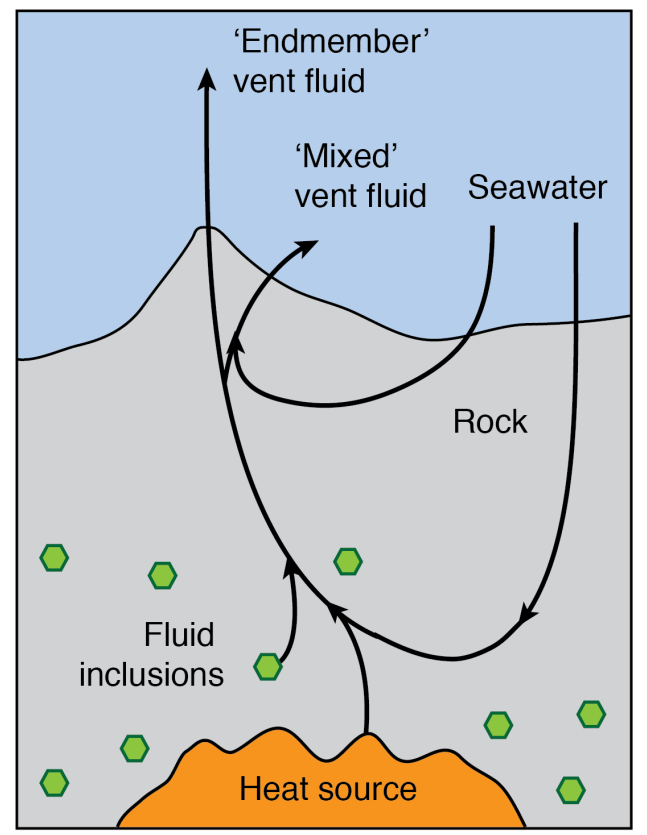

Figure 1. Schematic illustration of deep sea hydrothermal vent fluid formation. Circulating seawater undergoes chemical reaction with hot rock and is transformed into buoyant, hot 'endmember' hydrothermal fluids that vent at the seafloor. During circulation, fluids may entrain volatiles derived from magmatic degassing and from gas and fluid inclusions within the rock. Mixed vent fluids form when hot endmember fluids mix with cold ambient seawater in the shallow oceanic crust prior to venting. 


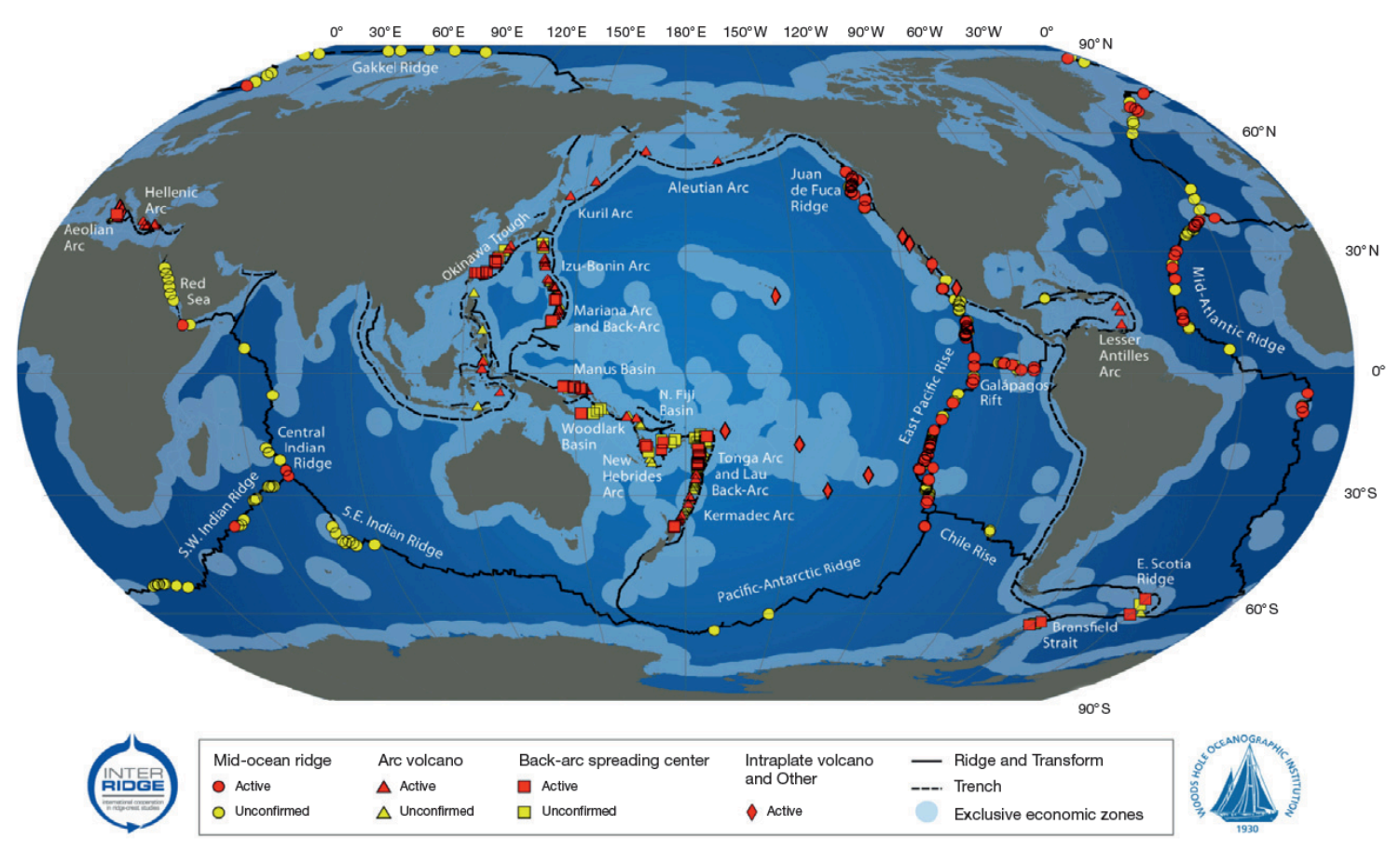

Figure 2. Map showing the major sections of the global mid-ocean ridge crest (black lines) from GERMAN and SEYFRIED (2014). Also shown are currently known locations of active hydrothermal venting (red symbols) and suspected locations of hydrothermal venting, based on identification of characteristic chemical anomalies in the water column (yellow symbols). A continuously updated vent site database and interactive map are hosted by the international InterRidge program at http://www.interridge.org/irvents/. 


\section{REFERENCES}

Allen, D.E., Seyfried, J., W E (2003) Compositional controls on vent fluids from ultramafichosted hydrothermal systems at mid-ocean ridges: An experimental study at $400^{\circ} \mathrm{C}, 500$ bars. Geochimica et Cosmochimica Acta 67, 1531-1542.

BAKer, E.T., Chen, Y., Morgan, J. (1996) The relationship between near-axis hydrothermal cooling and the spreading rate of mid-ocean ridges. Earth and Planetary Science Letters 142(1-2) 137-145.

Baker, E.T., Edmonds, H.N., Michael, P.J., Bach, W., Dick, H.J.B., Snow, J.E., Walker, S.L., BANERJEE, N.R., LANGMUIR, C.H. (2004) Hydrothermal venting in magma deserts: The ultraslow-spreading Gakkel and Southwest Indian Ridges. Geochemistry, Geophysics, Geosystems 5, doi: 10.1029/2004GC000712.

BAKER, E.T., GERMAN, C.R. (2004) On the global distribution of mid-ocean ridge hydrothermal vent-fields, in: German, C.R., Lin, J., Parson, L.M. (Eds.), Mid-Ocean Ridges:

Hydrothermal Interactions Between the Lithosphere and Oceans. American Geophysical Union Geophysical Monograph, Washington, DC, pp. 245-266.

BAROSS, J.A., HofFMAN, S.E. (1985) Submarine hydrothermal vents and associated gradient environments as sites for the origin and evolution of life. Origins of Life and Evolution of Biospheres 15, 327-345.

Berndt, M.E., AlLEn, D.E., Seyfried, W.E. (1996) Reduction of $\mathrm{CO}_{2}$ during serpentinization of olivine at $300^{\circ} \mathrm{C}$ and 500 bar. Geology 24, 351-354.

Bischoff, J., RosenBAUER, R. (1988) Liquid-vapor relations in the critical region of the system $\mathrm{NaCl}-\mathrm{H}_{2} \mathrm{O}$ from 380 to $415^{\circ} \mathrm{C}$ : A refined determination of the critical point and twophase boundary of seawater. Geochimica et Cosmochimica Acta 52, 2121-2126.

BischofF, J.L., RosenBAUER, R.J. (1985) An empirical equation of state for hydrothermal seawater (3.2\% NaCl). American Journal of Science 285, 725-763.

Bougault, H., Aballea, M., Radford-Knoery, J., Charlou, J., Baptiste, P., Appriou, P., Needham, H., German, C., Miranda, M. (1998) FAMOUS and AMAR segments on the Mid-Atlantic Ridge: ubiquitous hydrothermal $\mathrm{Mn}, \mathrm{CH}_{4}, \delta^{3} \mathrm{He}$ signals along the rift valley walls and rift offsets. Earth and Planetary Science Letters 161, 1-17. 
Charlou, J.L., Dmitriev, L., Bougault, H., Needham, H.D. (1988) Hydrothermal $\mathrm{CH}_{4}$ between $12^{\circ} \mathrm{N}$ and $15^{\circ} \mathrm{N}$ over the Mid-Atlantic Ridge. Deep Sea Research Part A 35(1), 121-131.

Charlou, J.L., Fouquet, Y., Bougault, H., Donval, J., Etoubleau, J., Jean-Baptiste, P., DAPOIGNY, A., APPriou, P., RonA, P. (1998) Intense $\mathrm{CH}_{4}$ plumes generated by serpentinization of ultramafic rocks at the intersection of the $15^{\circ} 20^{\prime} \mathrm{N}$ fracture zone and the Mid-Atlantic Ridge. Geochemica et Cosmochimica Acta 62, 2323-2333.

Charlou, J.L., Donval, J.P., Fouquet, Y., Jean-Baptiste, P., Holm, N. (2002) Geochemistry of high $\mathrm{H}_{2}$ and $\mathrm{CH}_{4}$ vent fluids issuing from ultramafic rocks at the Rainbow hydrothermal field ( $\left.36^{\circ} 14^{\prime} \mathrm{N}, \mathrm{MAR}\right)$. Chemical Geology 191, 345-359.

Charlou, J.L., Donval, J.P., Konn, C., Ondreas, H., Fouquet, Y., Jean-Baptiste, P., FOURR, E. (2010) High production and fluxes of $\mathrm{H}_{2}$ and $\mathrm{CH}_{4}$ and evidence of abiotic hydrocarbon synthesis by serpentinization in ultramafic-hosted hydrothermal systems on the Mid-Atlantic Ridge, Diversity of Hydrothermal Systems on Slow Spreading Ocean Ridges. American Geophysical Union Geophysical Monograph, Washington, DC, pp. 265-296.

Connelly, D.P., Copley, J.T., Murton, B.J., Stansfield, K., Tyler, P.A., German, C.R., Van Dover, C.L., Amon, D., Furlong, M., Grindlay, N., Hayman, N., HNerbach, V.H.u., Judge, M., Le Bas, T., McPhail, S., Meier, A., NaKamura, K.-I., Nye, V., Pebody, M., Pedersen, R.B., Plouviez, S., Sands, C., Searle, R.C., Stevenson, P., TAws, S., WiLCOX, S. (2012) Hydrothermal vent fields and chemosynthetic biota on the world's deepest seafloor spreading centre. Nature Communications 2, 1-9.

Corliss, J.B., Dymond, J., Gordon, L.I., Edmond, J.M., von Herzen, R.P., Ballard, R.D., Green, K., Williams, D., Bainbridge, A., Crane, K., van Andel, T.H. (1979) Submarine thermal springs on the Galápagos Rift. Science 203, 1073-1083.

Dick, H., Lin, J., Schouten, H. (2003) An ultraslow-spreading class of ocean ridge. Nature 426, 405-412.

Foustoukos, D.I., Seyfried JR., W.E. (2004) Hydrocarbons in hydrothermal vent fluids: The role of chromium-bearing catalysts. Science 304, 1002-1005.

German, C.R., Bowen, A., Coleman, M., Honig, D., Huber, J., Jakuba, M., Kinsey, J., Kurz, M., Leroy, S., McDermott, J.M., Mercier de Lépinay, B., NAKamura, K., Seewald, 
J.S., Smith, J.L., Sylva, S.P., VAn Dover, C.L., Whitcomb, L.L., Yoerger, D.R. (2010) Diverse styles of submarine venting on the ultraslow spreading Mid-Cayman Rise. Proceedings of the National Academy of Sciences 107, 14020-14025.

German, C.R., Lin, J. (2013) The Thermal Structure of the Oceanic Crust, Ridge-Spreading and Hydrothermal Circulation: How Well do we Understand their Inter-Connections?, MidOcean Ridges: Hydrothermal Interactions Between the Lithosphere and Oceans. American Geophysical Union Geophysical Monograph, Washington, DC, pp. 1-18.

German, C.R., Seyfried JR, W.E. (2014) Hydrothermal Processes, in: Holland, H.D., Turekian, K.K. (Eds.), Treatise on Geochemistry (Second Edition). Elsevier, Oxford, pp. 191-233. Hahse, K.M., Petersen, S., Koschinsky, A., Seifert, R., Devey, C.W., Keir, R., Lackschewitz, K.S., Melchert, B., Perner, M., Schmale, O., Süling, J., Dubilier, N., Zielinski, F., FretzdorfF, S., GARBe-SchÖnBERG, D., WeSternströer, U., German, C.R., Shank, T.M., Yoerger, D., Giere, O., Kuever, J., Marbler, H., Mawick, J., Mertens, C., Stöber, U., Walter, M., Ostertag-Henning, C., Paulick, H., Peters, M., Strauss, H., Sander, S., Stecher, J., Warmuth, M., Weber, S. (2007) Young volcanism and related hydrothermal activity at $5^{\circ} \mathrm{S}$ on the slow-spreading southern Mid-Atlantic Ridge. Geochemistry Geophysics Geosystems 8, doi: 10.1029/2006GC001509.

Hodgrinson, M., Murton, B.J., Roberts, S. (2012) Talc chimneys on the Mid Cayman Rise spreading centre. American Geophysical Union, Fall Meeting 2012, Abstract \#OS13B1738.

HORITA, J., BERNDT, M.E. (1999) Abiogenic methane formation and isotopic fractionation under hydrothermal conditions. Science 285(5430), 1055-1057.

JanNASCH, H.W., MotTL, M.J. (1985) Geomicrobiology of deep-sea hydrothermal vents. Science 229(4715), 717-725.

KARL, D.M. (1995) Ecology of free-living, hydrothermal vent microbial communities, in: Karl, D.M. (Ed.), The microbiology of deep-sea hydrothermal vents. CRC Press, pp. 35-124. KinSEY, J.C., German, C.R. (2013) Sustained volcanically-hosted venting at ultraslow ridges: Piccard Hydrothermal Field, Mid-Cayman Rise. Earth and Planetary Science Letters 380, 162-168. 
Klein, F., Bach, W., Jöns, N., McCollom, T., Moskowitz, B., Berquó, T. (2009) Iron partitioning and hydrogen generation during serpentinization of abyssal peridotites from $15^{\circ} \mathrm{N}$ on the Mid-Atlantic Ridge. Geochimica et Cosmochimica Acta 73, 6868-6893.

Klein, F., BACH, W., McCollom, T.M. (2013) Compositional controls on hydrogen generation during serpentinization of ultramafic rocks. Lithos 178, 55-69.

Koschinsky, A., Garbe-Schönberg, D., SAnder, S., Schmidt, K., Gennerich, H.-H., STRAUSS, H. (2008) Hydrothermal venting at pressure-temperature conditions above the critical point of seawater, $5^{\circ} \mathrm{S}$ on the Mid-Atlantic Ridge. Geology 36(8), 615-618.

LOWELL, R.P. (2013) Hydrothermal Circulation at Slow Spreading Ridges: Analysis of Heat Sources and Heat Transfer Processes, in: Rona, P.A., Devey, C.W., Dyment, J., Murton, B.J. (Eds.), Diversity Of Hydrothermal Systems On Slow Spreading Ocean Ridges. American Geophysical Union Geophysical Monograph, Washington, DC, pp. 11-26.

Martin, W., Baross, J., Kelley, D., Russell, M.J. (2008) Hydrothermal vents and the origin of life. Nature Reviews Microbiology 6, 805-814.

McCollom, T.M., Seewald, J.S. (2001) A reassessment of the potential for reduction of dissolved $\mathrm{CO}_{2}$ to hydrocarbons during serpentinization of olivine. Geochimica et Cosmochimica Acta 65, 3769-3778.

MCCOLlOM, T.M. (2003a) Experimental constraints on the hydrothermal reactivity of organic acids and acid anions: I. Formic acid and formate. Geochimica et Cosmochimica Acta 67(19), 3625-3644.

MCCOLlOM, T.M. (2003b) Experimental study of the hydrothermal reactivity of organic acids and acid anions: II. Acetic acid, acetate, and valeric acid. Geochimica et Cosmochimica Acta 67(19), 3645-3664.

McCollom, T.M., BACH, W. (2009) Thermodynamic constraints on hydrogen generation during serpentinization of ultramafic rocks. Geochimica et Cosmochimica Acta 73, 856-875.

MotTl, M.J., Holland, H.D. (1978) Chemical exchange during hydrothermal alteration of basalt by seawater - I. Experimental results for major and minor components of seawater. Geochimica et Cosmochimica Acta 42, 1103-1115.

Proskurowski, G., Lilley, M., Seewald, J., Fruh-Green, G., Olson, E., Lupton, J., Sylva, S., Kelley, D. (2008) Abiogenic hydrocarbon production at Lost City hydrothermal field. Science 319, 604-607. 
Rosencrantz, E., Ross, M., Sclater, J. (1988) Age and Spreading History of the Cayman Trough as Determined From Depth, Heat-Flow, and Magnetic-Anomalies. Journal of Geophysical Research-Solid Earth and Planets 93, 2141-2157.

Russell, M.J., Hall, A.J., Martin, W. (2010) Serpentinization as a source of energy at the origin of life. Geobiology 8, 355-371.

SEEWALD, J.S., SEYFrIED JR, W. (1990) The effect of temperature on metal mobility in subseafloor hydrothermal systems: constraints from basalt alteration experiments. Earth and Planetary Science Letters 101, 388-403.

SeEwald, J.S., Zolotov, M., McCollom, T. (2006) Experimental investigation of single carbon compounds under hydrothermal conditions. Geochimica et Cosmochimica Acta 70, 446-460.

SEYFRIED JR, W.E., BISCHOFF, J. (1981) Experimental seawater-basalt interaction at $300^{\circ} \mathrm{C}, 500$ bars, chemical exchange, secondary mineral formation and implications for the transport of heavy metals. Geochimica et Cosmochimica Acta 45, 135-147.

SEYFRIED JR, W. (1987) Experimental and theoretical constraints on hydrothermal alteration processes at mid-ocean ridges. Annual Review of Earth and Planetary Sciences 15, 317335.

SEYFried JR, W.E., Ding, K. (1995) Phase Equilibria in Subseafloor Hydrothermal Systems: a Review of the Role of Redox, Temperature, $\mathrm{pH}$ and Dissolved $\mathrm{Cl}$ on the Chemistry of Hot Spring Fluids at Mid-Ocean Ridges, in: Humphris, S.E., Zierenberg, R.A., Mullineaux, L.S., Thomson, R.E. (Eds.), Seafloor Hydrothermal Systems: Physical, Chemical, Biological, and Geological Interactions. American Geophysical Union Geophysical Monograph, Washington, DC, pp. 248-272.

SHOCK, E.L. (1990) Geochemical constraints on the origin of organic compounds in hydrothermal systems. Origins Life Evol Biosphere 20, 331-367.

SHOCK, E.L. (1992) Chemical Environments of Submarine Hydrothermal Systems, in: Holm, N.G. (Ed.), Marine Hydrothermal Systems and the Origin of Life. Springer Netherlands, pp. 67-107.

Shock, E.L., McCollom, T.M., Schulte, M.D. (1995) Geochemical constraints on chemolithoautotrophic reactions in hydrothermal systems. Origins Life Evol Biosphere 25, 141-159. 
SinHA, M.C., Evans, R.L. (2004) Geophysical constraints upon the thermal regime of the ocean crust, Mid-Ocean Ridges: Hydrothermal Interactions Between the Lithosphere and Oceans. American Geophysical Union Geophysical Monograph, Washington, DC, pp. $19-62$.

Takai, K., Nakamura, K., Toki, T., Tsunogai, U., Miyazaki, M., Miyazaki, J., Hirayama, H., Nakagawa, S., Nunoura, T., Horikoshi, K. (2008) Cell proliferation at $122^{\circ} \mathrm{C}$ and isotopically heavy $\mathrm{CH}_{4}$ production by a hyperthermophilic methanogen under highpressure cultivation. Proceedings of the National Academy of Sciences of the United States of America 105, 10949-10954.

VON DAMM, K.L., LiLley, M. (2004) Diffuse flow hydrothermal fluids from 950'N East Pacific Rise: Origin, evolution and biogeochemical controls, in: Wilcock, W., DeLong, E., Kelley, D., Baross, J., Cary, S. (Eds.), The Subseafloor Biosphere at Mid-Ocean Ridges. American Geophysical Union Geophysical Monograph, Washington, DC, pp. 245-268.

Von Damm, K.L. (1995) Temporal and compositional diversity in seafloor hydrothermal fluids. Reviews of Geophysics 33(S2) 1297-1305.

Wankel, S.D., Germanovich, L.N., Lilley, M.D., Genc, G., DiPerna, C.J., Bradley, A.S., OLSON, E.J., GIRGUIS, P.R. (2011) Influence of subsurface biosphere on geochemical fluxes from diffuse hydrothermal fluids. Nature Geoscience 4, 461-468. 


\title{
CHAPTER 2
}

\section{Distinct abiotic sources of aqueous organic species at the}

\section{Von Damm hydrothermal field}

\begin{abstract}
An abiotic origin of single-carbon compounds in deep-sea hot springs is compelling due to its implications for the sustenance of present-day microbial populations at vents (KELLEY et $a l ., 2002)$, and their potential role in the origin of life on early Earth (MARTIN et al., 2008).

Warm hydrogen-rich fluids, such as those emanating from serpentinizing hydrothermal systems, create a favorable thermodynamic drive for the abiotic reduction of inorganic carbon to organic compounds (SHOCK, 1990, 1992; SEEWALD et al., 2006). Here, the reaction pathways of abiotic organic synthesis in an active deep-sea hot spring are constrained, and the zones where inorganic carbon is converted into bio-available reduced carbon are delineated spatially. The timescales of carbon species transformations are identified, and show that within this single system reaction timescales range from hours and days to thousands of years. At the recently discovered Von Damm vent field, abiotic synthesis is revealed to occur via two distinct mechanisms. First, we show that abundant methane concentrations that occur in circulating fluids are likely formed in fluid inclusions. Abundant higher hydrocarbons are also observed in the fluids, and may derived
\end{abstract}


from the same source. This implies that alkanes may be formed independently of active circulation of serpentinizing hydrothermal fluids in all ultramafic-hosted vent systems studied todate, and are only subsequently released via circulating fluids to the overlying ocean. In addition, in subsurface mixing zones at Von Damm, widespread production of formate species from carbon dioxide occurs in the same fluids, and may support anaerobic methanogenesis in the deep biosphere.

\section{Main TeXT}

Seawater-derived hydrothermal fluids venting at oceanic spreading centers are a net source for dissolved carbon to the deep sea, with vent-fluid carbon contents directly tied to the sustenance of the subseafloor biosphere (KELLEY et al., 2002). Highly reducing fluids rich in dissolved $\mathrm{H}_{2}$, such as those emanating from serpentinizing hydrothermal systems, are of particular interest due to the potential for abiotic reduction of dissolved inorganic carbon $\left(\Sigma \mathrm{CO}_{2}\right.$ $=\mathrm{CO}_{2}+\mathrm{HCO}_{3}{ }^{-}+\mathrm{CO}_{3}{ }^{2-}$ ) to organic compounds (MCCOLLOM, 2003; SEEwALD et al., 2006; SHOCK, 1990, 1992; SHOCK and SCHUlTE, 1998). Although there is increasing evidence that supports an abiotic origin for $\mathrm{CH}_{4}$ and other low-molecular weight organic compounds in ultramafic-hosted hydrothermal systems (CHARLOU et al., 2002; CHARLOU et al., 2010; PROSKUROWSKI et al., 2008), the physical conditions, reaction pathways, and timescales that support abiotic organic synthesis at oceanic spreading centers remain elusive. Working models for the formation of abiotic methane and other hydrocarbons observed in vent fluids involve reduction of $\Sigma \mathrm{CO}_{2}$ and/or $\mathrm{CO}$ via Fischer-Tropsch-type processes or aqueous reduction during active circulation of seawater-derived hydrothermal fluids that are highly enriched in dissolved $\mathrm{H}_{2}$ due to serpentinization of host rocks. Others have suggested that leaching of $\mathrm{CH}_{4}$ and low 
molecular weight hydrocarbons from magmatic fluid inclusions hosted in plutonic rocks may contribute to the inventory of organic compounds observed in axial hot-spring fluids (KELLEY et al., 2002; Kelley and FrÜH-Green, 1999; MCCollom and SeEwald, 2007). The relative influence of these processes has important implications for the total flux and real-time concentration of aqueous organic compounds delivered to the seafloor by ridge-crest hydrothermal activity.

Here we show that aqueous organic species at an ultramafic-influenced hydrothermal system at the Mid-Cayman Rise (MCR) are produced abiotically in distinct locations within the oceanic crust over a broad range of timescales. In particular, $\mathrm{CH}_{4}$ is not actively forming during circulation of seawater-derived fluids that were observed venting at the seafloor, but instead is derived from fluid inclusions in the host rocks. In contrast, formate species $\left(\Sigma \mathrm{HCOOH}=\mathrm{HCOO}^{-}\right.$ $+\mathrm{HCOOH})$ are forming very rapidly during mixing of vent fluids with seawater in subseafloor reaction zones.

Located on the Mount Dent oceanic core complex at $2350 \mathrm{~m}$ depth on the MCR (CONNELly et al., 2012; GERMAN et al., 2010), hydrothermal vent fluids emanate from the Von Damm field at temperatures as high as $226^{\circ} \mathrm{C}$ (Fig. 1). Ultramafic, gabbroic, and basaltic rocks are associated with the oceanic core complex at Mt. Dent (BALLARD et al., 1979; HAYMAN et al., 2011; STROUP and Fox, 1981). The highest temperature fluid venting from the top of the mound at East Summit is characterized by high dissolved $\mathrm{H}_{2}(18.2 \mathrm{mmol} / \mathrm{L}), \mathrm{CH}_{4}(2.81 \mathrm{mmol} / \mathrm{L})$, elevated $\mathrm{C}_{2+}$ hydrocarbons, low dissolved metals, near-neutral $\mathrm{pH}\left(5.56,25^{\circ} \mathrm{C} 1 \mathrm{bar}\right)$, and nearzero concentrations of dissolved Mg (Table 1, Fig. A1A, Fig. 2A, Fig. A1B, Fig. A1C). Relative to seawater, dissolved $\mathrm{Cl}$ and $\mathrm{CO}_{2}$ in the endmember East Summit fluids are slightly enriched with concentrations of 651 and $2.80 \mathrm{mmol} / \mathrm{kg}$, respectively. Lower temperature fluids venting at 
the summit and along the flanks of the mound contain substantial concentrations of $\mathrm{Mg}$ suggesting that they have formed by subsurface mixing of a Mg-poor endmember hydrothermal fluid and cool Mg-rich seawater (BISCHOFF and DiCKSON, 1975). Aqueous concentrations of Cl, $\mathrm{CH}_{4}$, ethane $\left(\mathrm{C}_{2} \mathrm{H}_{6}\right)$, and propane $\left(\mathrm{C}_{3} \mathrm{H}_{8}\right)$ contents lie along a single conservative mixing line between the near zero-Mg East Summit vent fluid and high-Mg seawater, indicating that all fluids at Von Damm are derived from a single source fluid (Fig. A1D, Fig. 2A, Fig. A1B, Fig. A1C).

Elevated concentrations of dissolved $\mathrm{H}_{2}, \mathrm{CH}_{4}$, and low molecular weight hydrocarbons are consistent with the chemistry of Von Damm vent fluids being strongly influenced by serpentinization reactions in subseafloor reaction zones and are remarkably similar to abundances at other ultramafic-influenced hydrothermal systems (CHARLOU et al., 2002; Charlou et al., 2010; ProskURowsKi et al., 2008; SChMidT et al., 2007). The carbon isotopic composition of dissolved $\mathrm{CH}_{4}$ is uniform across the Von Damm vent field with a $\delta^{13} \mathrm{C}$ value of 15.4\%o (Table 1). This value is substantially heavier than values typically associated with thermogenic $\mathrm{CH}_{4}$ generation (-25 to $-50 \%$ ) and microbial production of $\mathrm{CH}_{4}$ from $\mathrm{CO}_{2}(-30$ to 70\%) (SCHOELL, 1980; VALENTINE et al., 2004) and provides evidence for an abiotic origin for $\mathrm{CH}_{4}$ at Von Damm. An abiotic origin for $\mathrm{CH}_{4}$ has been invoked at other ultramafic influenced systems at Rainbow, Logatchev, and Lost City hydrothermal fields where $\delta^{13} \mathrm{C}$ values for $\mathrm{CH}_{4}$ vary from -9 to -16\% (ChARLOU et al., 2002; ChARLOU et al., 2010; PROSKUROWSKI et al., 2008; SCHMIDT et al., 2007), encompassing the value reported here for Von Damm.

The abundance and isotopic composition of aqueous carbon species in the Von Damm endmember fluids place important constraints on deep-seated processes responsible for the abiotic production of $\mathrm{CH}_{4}$. Maximum fluid temperatures at Von Damm are $>150^{\circ} \mathrm{C}$ cooler than 
the two-phase boundary of seawater at seafloor pressure suggesting that the minor $\mathrm{Cl}$ enrichment cannot be the result of subsurface phase separation (BISCHOFF and ROSENBAUER, 1985) (Fig. A2). Accordingly, the 19\% enrichment in Von Damm endmember fluid Cl content (Fig. A1D) likely reflects the removal of water from seawater-derived fluids during serpentinization hydration reactions at low fluid/rock mass ratio (ALLEN and SEYFRIED, 2004). Applying a 19\% correction to a bottom seawater $\Sigma \mathrm{CO}_{2}$ concentration of $2.25 \mathrm{mmol} / \mathrm{kg}$ yields a predicted fluid $\Sigma \mathrm{CO}_{2}$ abundance of $2.69 \mathrm{mmol} / \mathrm{kg}$ that matches the observed endmember $\Sigma \mathrm{CO}_{2}$ of $2.80 \mathrm{mmol} / \mathrm{kg}$ at Von Damm within analytical error. The $\Sigma \mathrm{CO}_{2}$ abundance of the endmember fluid is thus nearly identical to that of ambient bottom seawater, suggesting that significant amounts of $\Sigma \mathrm{CO}_{2}$ are neither added to nor removed from the fluids during convective circulation in the subseafloor. This conclusion is further supported by the carbon isotopic composition of endmember $\Sigma \mathrm{CO}_{2}(0.9 \%)$ that is identical within error to that of bottom seawater (1.1\%o) at the MCR. The observation that $\Sigma \mathrm{CO}_{2}$ has been conserved during circulation through the crust has profound implications for the origin of $\mathrm{CH}_{4}$ at Von Damm since the endmember fluids have doubled their carbon content relative to seawater with the addition of $2.8 \mathrm{mmol} / \mathrm{kg} \mathrm{CH}_{4}$ (Fig. 2A, Table 1). Reduction of seawater-derived $\Sigma \mathrm{CO}_{2}$ to produce this level of $\mathrm{CH}_{4}$ would require substantial changes in the abundance and isotopic composition of residual $\Sigma \mathrm{CO}_{2}$. That the abundance and isotopic composition of $\Sigma \mathrm{CO}_{2}$ in the endmember fluid at Von Damm are nearly identical to its seawater source strongly indicates that it does not represent the source of carbon necessary for the abiotic formation of $\mathrm{CH}_{4}$, and implies that $\mathrm{CH}_{4}$ formation from inorganic sources is not occurring during active circulation of these fluids.

Radiocarbon analysis provides additional confirmation that $\mathrm{CH}_{4}$ at Von Damm is not derived from fluid $\Sigma \mathrm{CO}_{2}$. The four Von Damm $\mathrm{CH}_{4}$ samples measured, including the East 
Summit fluid, all reveal ${ }^{14} \mathrm{C}$ contents near the detectable limit $\left(\mathrm{F}_{\mathrm{m}}=0.0025\right.$, Table A1). In contrast, the same samples contain detectable modern $\Sigma \mathrm{CO}_{2}{ }^{14} \mathrm{C}$ contents (Table A1). Therefore, Von Damm fluid $\mathrm{CH}_{4}$ is most likely derived from leaching of radiocarbon-dead hydrocarbons from plutonic host rocks, rather than derived from reduction of fluid $\Sigma \mathrm{CO}_{2}$. This interpretation differs from a study at Lost City, where it has been postulated that fluid $\Sigma \mathrm{CO}_{2}$ contents are derived from fluid inclusions and are then reduced to $\mathrm{CH}_{4}$ during fluid circulation (ProskURowsKi et al., 2008).

In the absence of $\Sigma \mathrm{CO}_{2}$ reduction during convection of seawater-derived hydrothermal fluids through the oceanic crust, we suggest that $\mathrm{CH}_{4}$ and other low-molecular weight hydrocarbons in Von Damm vent fluids are derived from leaching of carbon-rich fluid inclusions at depth. We postulate that the abundant $\mathrm{CH}_{4}, \mathrm{C}_{2} \mathrm{H}_{6}$ and $\mathrm{C}_{3} \mathrm{H}_{8}$ in Von Damm vent fluids were formed when magmatic volatiles trapped in plutonic rocks re-equilibrated during cooling to temperatures $<400^{\circ} \mathrm{C}$, generating hydrocarbon-rich fluid-vapor inclusions, as described for $\mathrm{CH}_{4^{-}}$ rich Southwest Indian Ridge gabbros (SWIR) (Kelley, 1996; KelleY and FrÜH-GreEn, 1999). We propose that at Von Damm, these hydrocarbons were subsequently liberated and transported to the seafloor during hydrothermal alteration of lower crustal rocks associated with the Mount Dent oceanic core complex (BALlARD et al., 1979; HAYMAN et al., 2011; StROUP and FoX, 1981).

The isotopic composition of He in the Von Damm vent fluids indicates $R / R_{a}$ values of 8.0 to 8.2 suggesting a mantle source consistent with magmatic volatile-rich fluid inclusions (Table A2). Further, measured $\left.\mathrm{CH}_{4}\right|^{3} \mathrm{He}$ ratios $\left(\sim 2.4 \times 10^{8}\right)$ that are just below the average value of $\Sigma \mathrm{CO}_{2} /{ }^{3} \mathrm{He}$ measured in mantle rocks $\left(1 \times 10^{9}\right)($ MARTY and TOLSTIKHIN, 1998) also support a mantle (fluid inclusion) source for hydrocarbons. This $\mathrm{CH}_{4} /{ }^{\beta} \mathrm{He}$ ratio suggests a conversion of 
$\sim 24 \%$ of mantle-derived $\Sigma \mathrm{CO}_{2}$ to $\mathrm{CH}_{4}$. Formation of graphite, which can precipitate upon cooling of plutonic fluid inclusions (KELLEY and FRÜH-GREEN, 1999) may account for the remainder of the carbon. MCR gabbros range from 80 to $230 \mathrm{ppm}$ in leachable bulk volatile carbon content (KELLEY and FRÜH-GREEN, 2001). Under the assumption that $\mathrm{CH}_{4}$ is the dominant form of leachable volatile carbon in these inclusions, then a water/rock mass ratio of $\sim 2$ to 5 could generate the observed fluid $\mathrm{CH}_{4}$ contents at Von Damm. Due to the assumptions made, this is a maximum estimate.

$\mathrm{CH}_{4}$ observed in fluid inclusions from SWIR plutonic rocks is characterized by $\delta^{13} \mathrm{C}$ values of -10 to $-30 \%$ (Kelley et al., 2002; Kelley and FruH-GreEN, 2001), a range that includes the isotopic composition of $\mathrm{CH}_{4}$ observed in Von Damm vent fluids, consistent with a common origin. Isotope fractionation indicates an equilibration temperature of $370^{\circ} \mathrm{C}$ and $330^{\circ} \mathrm{C}$, for $\Delta_{\mathrm{CH} 4-\mathrm{C} 2 \mathrm{H} 6}$ and $\Delta_{\mathrm{CH} 4-\mathrm{C} 3 \mathrm{H} 8}$, respectively (GALIMOV and IVLEV, 1973) (Table 1). In a high- $\mathrm{H}_{2}, \leq 226^{\circ} \mathrm{C}$ fluid like that observed at Von Damm, thermodynamic considerations indicate that $\mathrm{CH}_{4}$ is expected to be the dominant form of dissolved carbon, relative to $\Sigma \mathrm{CO}_{2}$. Hence, fluid $\Sigma \mathrm{CO}_{2}$ and $\mathrm{CH}_{4}$ contents do not reflect chemical equilibrium at the conditions sampled. This decoupling is also documented in lower- $\mathrm{H}_{2}$ hydrothermal systems, where $\mathrm{CH}_{4}$ excesses relative to equilibrium with $\mathrm{CO}_{2}$ are ubiquitous, and where carbon isotope equilibration points to $\mathrm{CH}_{4}$ formation temperatures that are significantly greater than venting fluid temperatures (McCollom and SeEwald, 2007; Proskurowski et al., 2008). That the $\Sigma \mathrm{CO}_{2}, \mathrm{CH}_{4}, \mathrm{C}_{2} \mathrm{H}_{6}$, and $\mathrm{C}_{3} \mathrm{H}_{8}$ composition in Von Damm fluids reflects chemical as well as isotopic disequilibrium at measured temperatures indicates a decoupling of hydrocarbons and $\mathrm{CO}_{2}$ that is consistent with our fluid inclusion model. Hence, fluid inclusions may be an important source of hydrocarbons to vent fluids worldwide, and differences in vent fluid hydrocarbon abundances may reflect 
varying extraction efficiencies of leachable hydrocarbons. These hydrocarbons are formed in the crust on much longer timescales than the residence times of active hydrothermal systems. The fact that hydrocarbons are not formed as a consequence of active fluid circulation alleviates the need to invoke heterogeneous catalysts as a means to account for rapid $\mathrm{CH}_{4}$ formation in hydrothermal systems (BERNDT et al., 1996; Foustoukos et al., 2004; HORITA and BERNDT, 1999; MCCollom and SeEWALD, 2001).

In contrast to dissolved $\mathrm{CH}_{4}$ concentrations, concentrations of $\Sigma \mathrm{CO}_{2}$ in mixed fluids at Von Damm are depleted by as much as $25 \%$ relative to expected concentrations during conservative mixing, and are ${ }^{13} \mathrm{C}$-enriched (Fig. 2B). These depletions are accompanied by significantly enriched $\Sigma \mathrm{HCOOH}$ abundances of 73 to $605 \mu \mathrm{mol} / \mathrm{kg}$ relative to conservative mixing (Fig. 2C), suggesting that abiotic $\mathrm{\Sigma} \mathrm{HCOOH}$ formation in subsurface mixing zones represents a sink for vent fluid $\Sigma \mathrm{CO}_{2}$. Consistent with this, the amount of carbon present as the sum of $\Sigma \mathrm{HCOOH}$ and $\Sigma \mathrm{CO}_{2}$ in the endmember fluid at East Summit is conserved during mixing in the cooler fluids (Fig 2D; Fig. A1D). Despite a strong thermodynamic drive, $\mathrm{CH}_{4}$ production from $\Sigma \mathrm{CO}_{2}$ does not occur due to well-established kinetic limitations, therefore permitting formation of the metastable intermediate $\Sigma \mathrm{HCOOH}$ species. Reduction of $\Sigma \mathrm{CO}_{2}$ by $\mathrm{H}_{2}$ in mixed fluids $\left(\mathrm{CO}_{2}+\mathrm{H}_{2}=\mathrm{HCOOH}\right)$ is consistent with thermodynamic predictions in the absence of $\mathrm{CH}_{4}$ production, and with laboratory experiments that have demonstrated rapid reaction kinetics and isotopic enrichment of the residual $\Sigma \mathrm{CO}_{2}$ (MCCOLLOM, 2003; SEEWALD et al., 2006).

Fluid compositions are consistent with metastable thermodynamic equilibrium between $\Sigma \mathrm{CO}_{2}, \Sigma \mathrm{HCOOH}$, and $\mathrm{H}_{2}$ in Von Damm mixed fluids, providing further support for an abiotic origin. Formation of $\mathrm{\Sigma HCOOH}$ upon mixing represents a move to a near-equilibrium condition as indicated by decreasing chemical affinities that reach values below $5 \mathrm{~kJ} / \mathrm{mole}$ for most of the 
sampled fluids (Fig. 3). Thus, unlike $\mathrm{CH}_{4}$, the absence of kinetic barriers allows for abiotic synthesis of metastable $\mathrm{\Sigma HCOOH}$ in the subsurface mixing zone during active circulation of submarine hydrothermal fluids.

Vent microorganisms inhabit environments dominated by mixed hydrothermal fluids, where $\Sigma \mathrm{HCOOH}$ can be utilized as an energy or fixed carbon source via methanogenesis. With abundances approaching those of $\mathrm{CO}_{2}, \Sigma \mathrm{HCOOH}$-based methanogenesis could be a viable strategy at Von Damm. Indeed, biological utilization of $\Sigma \mathrm{HCOOH}$ in the generation of $\mathrm{CH}_{4}$ under anaerobic conditions has been identified at $70^{\circ} \mathrm{C}$ at Ginger Castle and East Summit vents by stable isotope tracing experiments (REVEILLAUD et al., in prep.). Our results show that abiotic $\Sigma \mathrm{HCOOH}$ may represent an important substrate for microrganisms in high- $\mathrm{H}_{2}$ and near-neutral hydrothermal fluids, as has been postulated for Lost City (LANG et al., 2010; LANG et al., 2012). Fluid circulation at Von Damm integrates abiotic organic species formed on long as well as short timescales, as fluids contain $\mathrm{CH}_{4}$ leached from magmatic volatile fluid inclusions and $\Sigma \mathrm{HCOOH}$ formed during shallow mixing. Abiotic organic synthesis in vent fluids would have profound implications for naturally-occurring prebiotic organic chemistry on the early Earth and other planetary bodies (MARTIN et al., 2008; MARTIN and RUSSELL, 2007; RUSSELL et al., 2010). The identification of $\Sigma \mathrm{HCOOH}$-based metabolic strategies in active fluid microbial populations highlights the importance of abiotic metastable organic synthesis in supporting life in the subseafloor oceanic crust at hydrothermal vents, and presents exciting implications for life strategies in any moderate-temperature high- $\mathrm{H}_{2}$ natural waters. 
Table 1. Measured and calculated abundance and stable isotope data for Von Damm vent fluids.

\begin{tabular}{|c|c|c|c|c|c|c|c|c|c|c|c|c|c|c|c|}
\hline Vent & Sample & $\begin{array}{c}\mathrm{T} \\
{ }^{\circ} \mathrm{C}\end{array}$ & $\begin{array}{c}\mathrm{Mg} \\
\mathrm{mm}^{\ddagger}\end{array}$ & $\mathrm{pH}^{\dagger}$ & $\begin{array}{c}\mathrm{Cl} \\
\mathrm{mm}\end{array}$ & $\begin{array}{c}\mathrm{H}_{2} \\
\mathrm{mM}^{\frac{1}{t}}\end{array}$ & $\begin{array}{c}\Sigma \mathrm{HCOOH}^{\S} \\
\mu \mathrm{m}^{\ddagger}\end{array}$ & $\begin{array}{c}\Sigma \mathrm{CO}_{2} \\
\mathrm{~mm}\end{array}$ & $\begin{array}{l}\mathrm{CH}_{4} \\
\mathrm{mM}\end{array}$ & $\begin{array}{c}\mathrm{C}_{2} \mathrm{H}_{6} \\
\mathrm{~nm}^{\ddagger}\end{array}$ & $\begin{array}{c}\mathrm{C}_{3} \mathrm{H}_{8} \\
\mathrm{~nm}\end{array}$ & $\begin{array}{c}\delta^{13} \mathrm{C}_{\mathrm{CO} 2} \\
\% 0\end{array}$ & $\begin{array}{c}\delta^{13} \mathrm{C}_{\mathrm{CH} 4} \\
\%\end{array}$ & $\begin{array}{c}\delta^{13} \mathrm{C}_{\mathrm{C} 2 \mathrm{H} 6} \\
\% 0\end{array}$ & $\begin{array}{c}\delta^{13} \mathrm{C}_{\mathrm{C} 3 \mathrm{H} 8} \\
\% 0\end{array}$ \\
\hline East Summit & Endmember & - & 0 & 5.56 & 651 & 18.2 & 88.2 & 2.80 & 2.81 & 639 & 56 & $\mathrm{~N} / \mathrm{A}^{\|}$ & N/A & N/A & N/A \\
\hline$\overline{\text { East Summit }}$ & $\mathrm{J} 2-612-\mathrm{IGT} 2$ & $2 \bar{c}$ & $\overline{2.9} \overline{3}$ & $\overline{5} . \overline{65}$ & $-\overline{649}$ & $\overline{16} . \overline{2}$ & $82 . \overline{0}$ & $2 . \overline{79}$ & $\overline{2} . \overline{6}$ & $\overline{603}$ & $5 \overline{2}$ & $0 . \overline{8}$ & $-\overline{15} . \overline{6}$ & $-\overline{-12.9}$ & $-\overline{-9.8}$ \\
\hline East Summit & J2-616-IGT8 & 226 & 2.43 & 5.56 & 641 & 18.3 & 85.6 & 2.75 & 2.72 & - & - & 0.9 & -15.3 & -12.3 & - \\
\hline White Castle & J2-616-IGT1 & 151 & 13.5 & 5.77 & 622 & 13.1 & $352^{\S}$ & 2.51 & 2.08 & 485 & 41 & 1.5 & -15.6 & - & - \\
\hline Ginger Castle & J2-617-IGT4 & 125 & 18.0 & 6.06 & 604 & 11.3 & 337 & 2.35 & 1.88 & - & - & 2.2 & -15.8 & -13.2 & -10.8 \\
\hline Ravelin \#1 & J2-617-IGT6 & 145 & 15.0 & 5.83 & 614 & 13.4 & 147 & 2.52 & 2.02 & - & - & 1.9 & -15.6 & - & - \\
\hline Ravelin \#1 & J2-617-IGT2 & 131 & 16.8 & 5.93 & 616 & 13.1 & 132 & 2.40 & 1.96 & 431 & 38 & 1.4 & -15.1 & - & - \\
\hline Arrow Loop \#1 & J2-616-IGT6 & 134 & 18.5 & 5.86 & 616 & 10.8 & 274 & 2.27 & 1.74 & 417 & 36 & 1.9 & -15.7 & -12.5 & - \\
\hline West Summit & J2-621-IGT1 & 123 & 24.0 & 6.00 & 605 & 9.9 & 428 & 2.08 & 1.64 & 359 & 30 & 3.3 & -15.6 & -12.6 & - \\
\hline West Summit & J2-621-IGT4 & 123 & 23.2 & 6.01 & 597 & 9.9 & 428 & 2.07 & 1.67 & 335 & 29 & 3.6 & -15.1 & - & - \\
\hline Ravelin \#2 & J2-621-IGT2 & 116 & 13.4 & 5.88 & 620 & 13.6 & $-\|$ & 1.98 & 2.10 & 475 & 40 & 3.8 & -15.1 & -12.9 & -9.7 \\
\hline Ravelin \#2 & J2-621-IGT8 & 115 & 22.0 & 6.12 & 600 & 10.9 & 474 & 1.88 & 1.73 & 365 & 34 & 3.3 & -15.4 & -12.7 & - \\
\hline Old Man Tree & J2-612-IGT6 & 115 & 14.4 & 5.81 & 620 & 10.5 & 663 & 1.80 & 1.97 & - & - & 2.6 & -15.2 & - & - \\
\hline Old Man Tree & J2-612-IGT8 & 114 & 14.0 & 5.89 & 621 & 10.2 & 669 & 2.03 & 1.92 & 455 & 40 & 2.9 & -15.0 & -12.6 & -11.6 \\
\hline Shrimp Hole & J2-617-IGT1 & 21 & 46.1 & 7.73 & 549 & 0.01 & $\mathrm{BD}^{\|}$ & 2.01 & 0.29 & 51.8 & 4.6 & 1.1 & -15.1 & - & - \\
\hline Bottom SW & & $\sim 5$ & 52.4 & $\sim 8$ & 545 & 0 & $\sim 1$ & 2.25 & 0 & 0 & 0 & 1.1 & N/A & $\mathrm{N} / \mathrm{A}$ & N/A \\
\hline
\end{tabular}

${ }^{\dagger}$ Shipboard $\mathrm{pH}$ is reported $\left(25^{\circ} \mathrm{C}, 1 \mathrm{~atm}\right)$

$\$ \mathrm{~mm}, \mathrm{mmol} / \mathrm{kg} ; \mathrm{mM}, \mathrm{mmol} / \mathrm{L} ; \mu \mathrm{m}, \mu \mathrm{mol} / \mathrm{kg} ; \mathrm{nm}, \mathrm{nmol} / \mathrm{kg}$

§Bold entries denote sample used to calculate measured affinities in Fig 2.

"'BD', below detection (1.0 $\mu \mathrm{m}$ for $\Sigma \mathrm{HCOOH}, 2.0 \mathrm{~nm}$ for $\mathrm{n}-\mathrm{C}_{4} \mathrm{H}_{10}$ and $\left.\mathrm{i}-\mathrm{C}_{4} \mathrm{H}_{10}\right)$; 'N/A', not applicable, '-' not determined.

Analytical uncertainties $(2 \sigma)$ are $\pm 2^{\circ} \mathrm{C}$ for $\mathrm{T}, 3 \%$ for $\mathrm{Mg}$ and $\mathrm{Cl}, 5 \%$ for $\mathrm{H}_{2}, \Sigma \mathrm{HCOOH}, \Sigma \mathrm{CO}_{2}, \mathrm{CH}_{4}, \mathrm{C}_{2} \mathrm{H}_{6}$, and $\mathrm{C}_{3} \mathrm{H}_{8} ; \pm 0.05$ units for pH;

$\pm 0.3 \%$ for $\delta^{13} \mathrm{C}_{\mathrm{CO} 2} ; \pm 0.8 \%$ for $\delta^{13} \mathrm{C}_{\mathrm{CH} 4} ; \pm 0.4 \%$ for $\delta^{13} \mathrm{C}_{\mathrm{C} 2 \mathrm{H} 6} ; \pm 0.7 \%$ for $\delta^{13} \mathrm{C}_{\mathrm{C} 3 \mathrm{H} 8}$. 


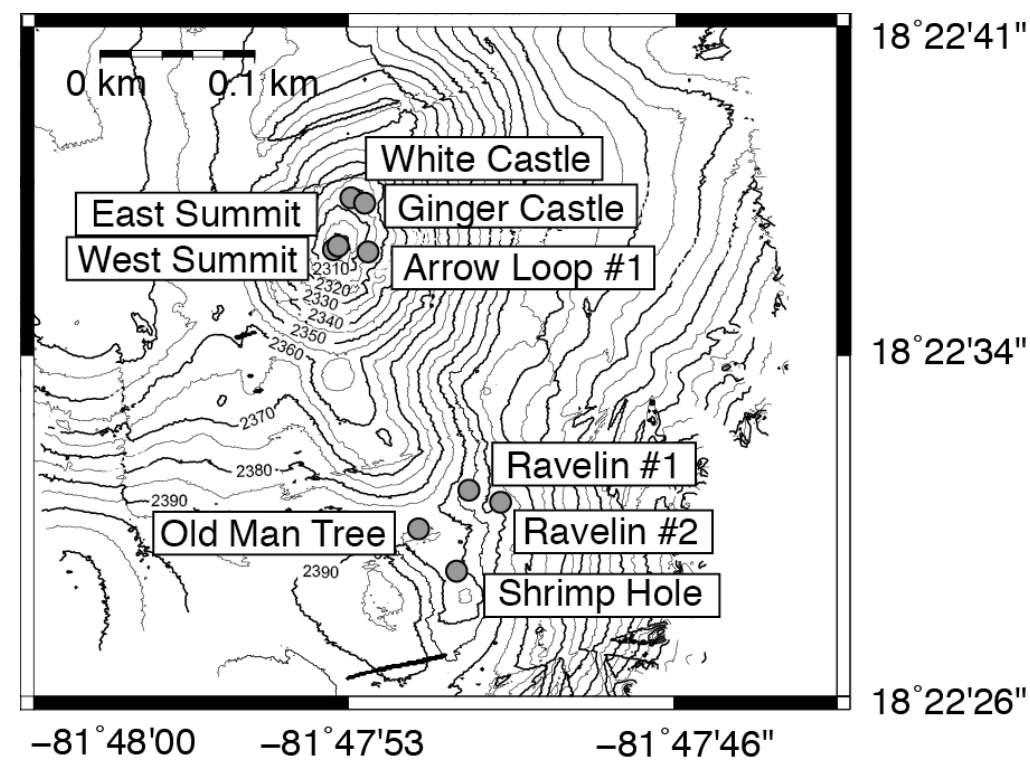

Figure 1. Bathymetry of the Von Damm hydrothermal field, with locations of fluid sampling indicated with circles. 

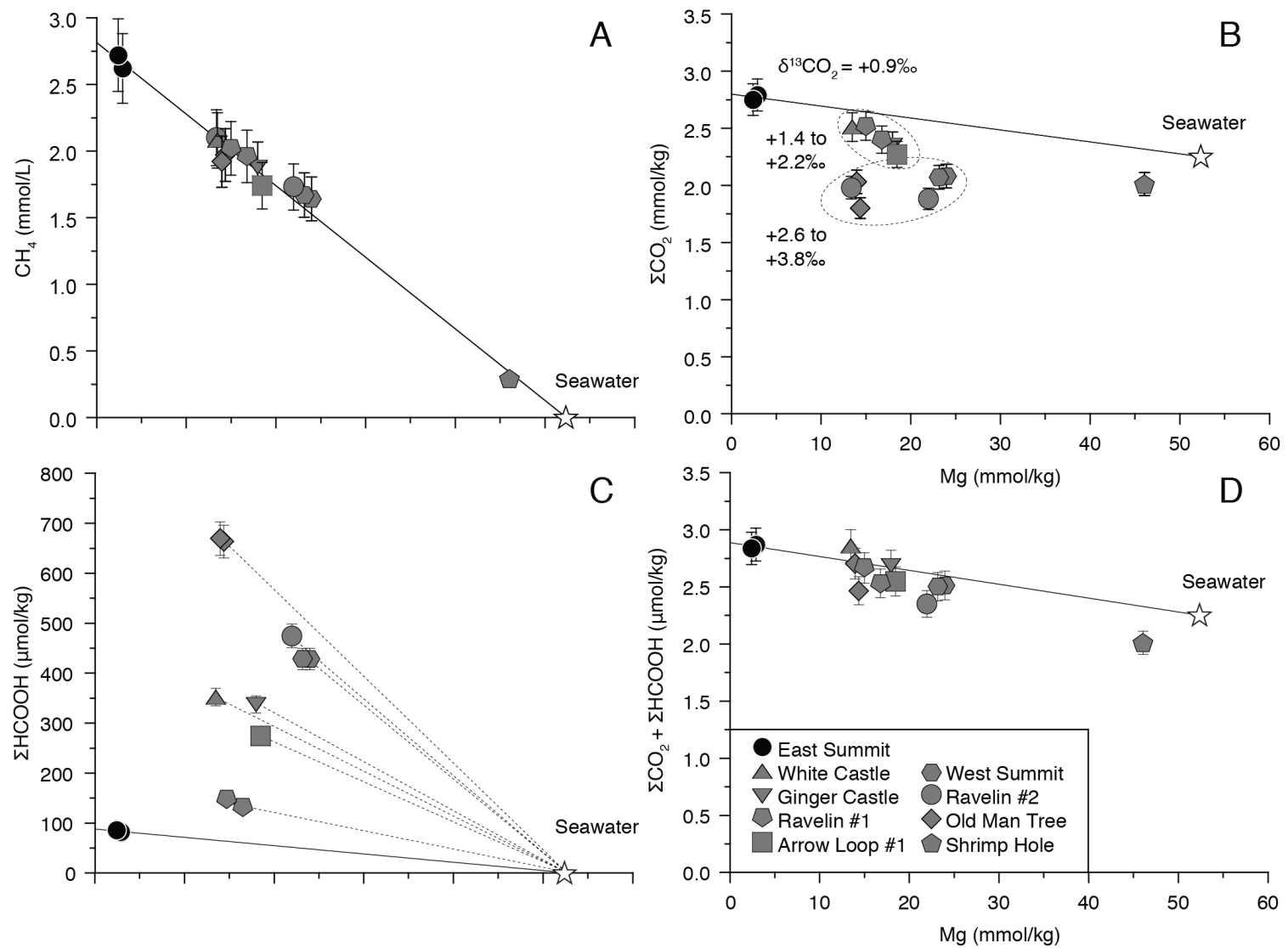

Figure 2. Plot of measured $\mathrm{Mg}$ versus $\mathrm{CH}_{4}(\mathrm{~A}), \Sigma \mathrm{CO}_{2}(\mathrm{~B}), \Sigma \mathrm{HCOOH}(\mathrm{C})$, and $\Sigma \mathrm{CO}_{2}+$ $\Sigma \mathrm{HCOOH}$ (D) concentrations for Von Damm vent fluids. Mg content is used as an indicator for seawater mixing; solid lines denote conservative dilution of the endmember composition (black circles), while dashed lines show non-conservative behavior in mixed fluid compositions (gray symbols). Select $\delta^{13} \mathrm{C}_{\mathrm{CO} 2}$ values are plotted in (B) next to corresponding samples. Uncertainties $(2 \sigma)$ not shown are smaller than symbols. 


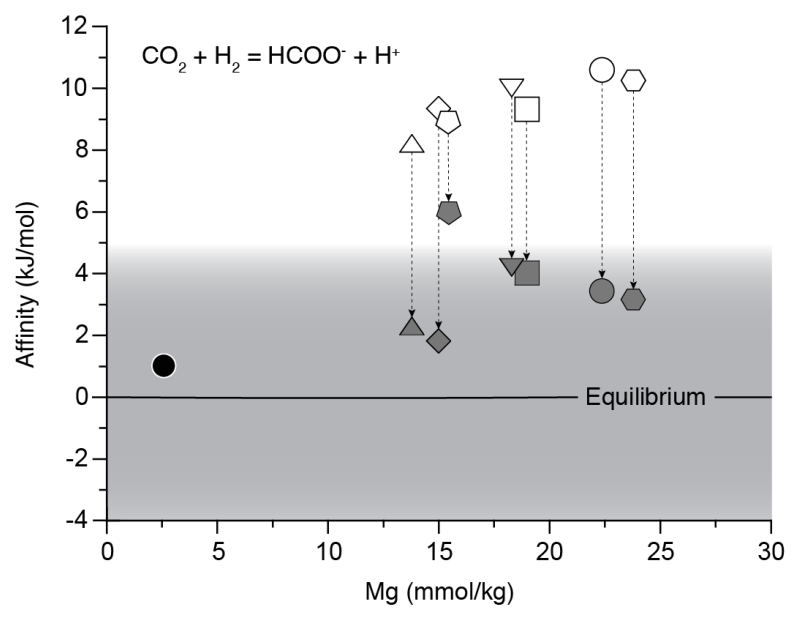

Figure 3. Chemical affinity for the production of $\mathrm{HCOO}^{-}$from $\Sigma \mathrm{CO}_{2}$ and $\mathrm{H}_{2}$ in Von Damm mixed fluids. Open symbols indicate a favorable thermodynamic drive for reaction (positive Affinity $(A)$ ) based on conservative dilution of the endmember $\Sigma \mathrm{HCOOH}$ composition (black circle; SOM). Gray symbols denote $A$ calculated with actual mixed fluid $\Sigma \mathrm{HCOOH}$ contents. Thermodynamic equilibrium is defined as $A=0 \pm 5 \mathrm{~kJ} / \mathrm{mol}$. Individual orifice symbols correspond to Fig. 1 legend. 


\section{REFERENCES}

Allen, D.E., Seyfried, J., W E (2004) Serpentinization and heat generation: constraints from Lost City and Rainbow hydrothermal systems. Geochimica et Cosmochimica Acta $\mathbf{6 8}$, 1347-1354.

Ballard, R.D., Bryan, W.B., Davis, K., De Boer, J., DeLong, S., Dick, H., Emery, K.O., Fox, P.J., Hempton, M., Malcolm, F., Melson, W.G., Spydell, K., Stroup, J.B., ThOMPSON, G., Wright, R., UCHUPI, E. (1979) Geological and geophysical investigation of the Mid-Cayman Rise spreading center: Initial results and observations, in: Talwani, M., Harrison, C.G., Hayes, D.E. (Eds.), Deep Drilling Results in the Atlantic Ocean: Ocean Crust. American Geophysical Union, Washington, D.C., pp. 66-93.

Berndt, M.E., Allen, D.E., Seyfried, W.E. (1996) Reduction of $\mathrm{CO}_{2}$ during serpentinization of olivine at $300^{\circ} \mathrm{C}$ and 500 bar. Geology 24, 351-354.

Bischoff, J.L., Dickson, F. (1975) Seawater-basalt interaction at $200^{\circ} \mathrm{C}$ and 500 bars: implications for origin of sea-floor heavy-metal deposits and regulation of seawater chemistry. Earth and Planetary Science Letters 25, 385-397.

BisCHOFF, J.L., RosenBAUER, R.J. (1985) An empirical equation of state for hydrothermal seawater $(3.2 \% \mathrm{NaCl})$. American Journal of Science 285, 725-763.

Charlou, J.L., Donval, J.P., Fouquet, Y., Jean-Baptiste, P., Holm, N. (2002) Geochemistry of high $\mathrm{H}_{2}$ and $\mathrm{CH}_{4}$ vent fluids issuing from ultramafic rocks at the Rainbow hydrothermal field (36 $14^{\prime}$ N, MAR). Chemical Geology 191, 345-359.

Charlou, J.L., Donval, J.P., Konn, C., Ondréas, H., Fouquet, Y., Jean-BaPtiste, P., FOURRÉ, E. (2010) High production and fluxes of $\mathrm{H}_{2}$ and $\mathrm{CH}_{4}$ and evidence of abiotic hydrocarbon synthesis by serpentinization in ultramafic-hosted hydrothermal systems on the Mid-Atlantic Ridge, Diversity of Hydrothermal Systems on Slow Spreading Ocean Ridges. American Geophysical Union Geophysical Monograph, Washington, DC, pp. 265-296.

Connelly, D.P., Copley, J.T., Murton, B.J., Stansfield, K., Tyler, P.A., German, C.R., Van Dover, C.L., Amon, D., Furlong, M., Grindlay, N., Hayman, N., Hühnerbach, V., Judge, M., Le Bas, T., McPhail, S., Meier, A., Nakamura, K.-I., Nye, V., Pebody, M., Pedersen, R.B., Plouviez, S., Sands, C., Searle, R.C., Stevenson, P., Taws, S., WiLCOX, S. (2012) Hydrothermal vent fields and chemosynthetic biota on the world's 
deepest seafloor spreading centre. Nature Communications 3(620), doi:

$10.1038 /$ ncomms 1636.

Foustoukos, D.I., SEYFried JR., W.E. (2004) Hydrocarbons in hydrothermal vent fluids: The role of chromium-bearing catalysts. Science 304, 1002-1005.

Galimov, E., IVlev, A. (1973) Thermodynamic isotope effects in organic compounds. I. Carbon isotope effects in straight-chain alkanes Russian Journal of Physical Chemistry 47, 1564-1566.

German, C.R., Bowen, A., Coleman, M., Honig, D., Huber, J., Jakuba, M., Kinsey, J., Kurz, M., Leroy, S., McDermott, J.M., Mercier de LéPinay, B., NAKAMUra, K., SeEwald, J.S., Smith, J.L., SYlva, S.P., Van Dover, C.L., Whitcomb, L.L., Yoerger, D.R. (2010) Diverse styles of submarine venting on the ultraslow spreading Mid-Cayman Rise. Proceedings of the National Academy of Sciences 107, 14020-14025.

Hayman, N.W., Grindlay, N.R., Perfit, M.R., Mann, P., Leroy, S., De LéPinay, B.M. (2011) Oceanic core complex development at the ultraslow spreading Mid-Cayman Spreading Center. Geochemistry Geophysics Geosystems 12(3), doi: 10.1029/2010GC003240.

HoritA, J., BERndT, M.E. (1999) Abiogenic methane formation and isotopic fractionation under hydrothermal conditions. Science 285, 1055-1057.

KELLEY, D.S. (1996) Methane-rich fluids in the oceanic crust. Journal of Geophysical Research 101, 2943-2962.

Kelley, D.S., Baross, J.A., Delaney, J.R. (2002) Volcanoes, fluids, and life at Mid-Ocean Ridge Spreading Centers. Annual Review of Earth and Planetary Sciences 30, 385-491.

Kelley, D.S., FrÜH-Green, G.L. (2001) Volatile lines of descent in submarine plutonic environments: insights from stable isotope and fluid inclusion analyses. Geochimica et Cosmochimica Acta 65, 3325-3346.

Kelley, D.S., FrÜH-Green, G.L. (1999) Abiogenic methane in deep-seated mid-ocean ridge environments: Insights from stable isotope analyses. Journal of Geophysical Research 104, 10439-10460.

LANG, S.Q., Butterfield, D.A., Schulte, M., Kelley, D.S., Lilley, M.D. (2010) Elevated concentrations of formate, acetate and dissolved organic carbon found at the Lost City hydrothermal field. Geochimica et Cosmochimica Acta 74, 941-952. 
Lang, S.Q., Früh-Green, G.L., Bernasconi, S.M., Lilley, M.D., Proskurowski, G., Méhay, S., ButTERFIELD, D.A. (2012) Microbial utilization of abiogenic carbon and hydrogen in a serpentinite-hosted system. Geochimica et Cosmochimica Acta 92, 82-99.

Martin, W., Baross, J., Kelley, D., Russell, M.J. (2008) Hydrothermal vents and the origin of life. Nature Reviews Microbiology 6, 805-814.

MARTIN, W., RusSELL, M.J. (2007) On the origin of biochemistry at an alkaline hydrothermal vent. Philosophical Transactions of the Royal Society B: Biological Sciences 362, $1887-$ 1926.

Marty, B., Tolstikhin, I.N. (1998) $\mathrm{CO}_{2}$ fluxes from mid-ocean ridges, arcs and plumes. Chemical Geology 145, 233-248.

MCCOLlOM, T. (2003) Experimental constraints on the hydrothermal reactivity of organic acids and acid anions: I. Formic acid and formate. Geochimica et Cosmochimica Acta 67, 3625-3644.

McCollom, T.M., SeEwald, J.S. (2001) A reassessment of the potential for reduction of dissolved $\mathrm{CO}_{2}$ to hydrocarbons during serpentinization of olivine. Geochimica et Cosmochimica Acta 65, 3769-3778.

McCollom, T.M., SEewald, J.S. (2007) Abiotic synthesis of organic compounds in deep-sea hydrothermal environments. Chem. Rev. 107, 382-401.

Proskurowski, G., Lilley, M., Seewald, J., Fruh-Green, G., Olson, E., Lupton, J., Sylva, S., Kelley, D. (2008) Abiogenic hydrocarbon production at Lost City hydrothermal field. Science 319(5863), 604-607.

Reveillaud, J., Reddington, E., McDermott, J.M., Meyer, J., Sylva, S.P., Seewald, J.S., German, C.R., Huber, J. (in prep.) Subseafloor microbial communities in hydrogen-rich vent fluids from hydrothermal systems along the Mid-Cayman Rise.

Russell, M.J., Hall, A.J., Martin, W. (2010) Serpentinization as a source of energy at the origin of life. Geobiology 8, 355-371.

Schmidt, K., Koschinsky, A., Garbe-Schönberg, D., De Carvalho, L., Seifert, R. (2007) Geochemistry of hydrothermal fluids from the ultramafic-hosted Logatchev hydrothermal field, $15^{\circ} \mathrm{N}$ on the Mid-Atlantic Ridge: Temporal and spatial investigation. Chemical Geology 242, 1-21. 
SCHOELL, M. (1980) The hydrogen and carbon isotopic composition of methane from natural gases of various origins. Geochimica et Cosmochimica Acta 44, 649-661.

Seewald, J.S., Zolotov, M., McCollom, T. (2006) Experimental investigation of single carbon compounds under hydrothermal conditions. Geochimica et Cosmochimica Acta 70, 446-460.

SHOCK, E.L. (1990) Geochemical constraints on the origin of organic compounds in hydrothermal systems. Origins Life Evol Biosphere 20, 331-367.

SHock, E.L. (1992) Chemical Environments of Submarine Hydrothermal Systems, in: Holm, N.G. (Ed.), Marine Hydrothermal Systems and the Origin of Life. Springer Netherlands, pp. 67-107.

SHock, E.L., Schulte, M.D. (1998) Organic synthesis during fluid mixing in hydrothermal systems. Journal of Geophysical Research: Planets 103, 28513-28527.

Stroup, J., Fox, P. (1981) Geologic Investigations in the Cayman Trough: Evidence for Thin Oceanic-Crust Along the Mid-Cayman Rise. Journal of Geology 89, 395-420.

Valentine, D.L., Chidthaisong, A., Rice, A., Reeburgh, W.S., Tyler, S.C. (2004) Carbon and hydrogen isotope fractionation by moderately thermophilic methanogens. Geochimica et Cosmochimica Acta 68, 1571-1590. 


\section{APPENDIX}

\subsection{Hydrothermal vent fluid sampling and methods}

Vent fluid samples were collected using $150 \mathrm{~mL}$ titanium isobaric gas-tight (IGT) samplers (SEEwALD et al., 2002) deployed by the ROV Jason II aboard the R/V Atlantis cruise AT18-16 in January 2012. During the 1-2 minute sampler filling time, fluid temperatures were monitored continuously with thermocouples aligned with inlet snorkel tips. Thermocouples were calibrated with a National Institute of Standards and Technology (NIST) temperature calibrator, and the maximum measured temperature for each sample is reported (Table 1). Due to variability in dive duration, 5-20 hours elapsed between sampling on the seafloor and sample recovery.

Samples were extracted and processed within $24 \mathrm{~h}$ following sampler recovery. Aliquots were extracted for shipboard analysis of $\mathrm{pH}$ and volatile species $\left(\mathrm{CH}_{4}, \mathrm{H}_{2}\right)$ and for shore-based analysis of major species and total dissolved inorganic carbon $\left(\Sigma \mathrm{CO}_{2}=\mathrm{CO}_{3}{ }^{2-}+\mathrm{HCO}_{3}{ }^{-}+\right.$ $\left.\mathrm{H}_{2} \mathrm{CO}_{3}\right)$. Immediately after withdrawing the fluid aliquot from the IGT sampler, $\mathrm{pH}\left(25^{\circ} \mathrm{C}, 1\right.$ atm) was measured onboard ship by potentiometry using a $\mathrm{Ag} / \mathrm{AgCl}$ reference electrode. Aliquots were withdrawn into glass gastight syringes for shipboard $\mathrm{H}_{2}$ and $\mathrm{CH}_{4}$ analysis by molecular sieve gas chromatography (GC) with thermal conductivity detection after gastight syringe headspace extraction. Aliquots for later shore-based $\Sigma \mathrm{CO}_{2}$ abundance and $\mathrm{CH}_{4}$ and $\Sigma \mathrm{CO}_{2}$ stable and radioisotopic carbon isotope analysis were transferred to evacuated $25 \mathrm{~mL}$ serum vials sealed with butyl rubber stoppers, a subset of which were poisoned with $\mathrm{Hg}_{2} \mathrm{Cl}$ to inhibit microbial activity. Butyl rubber stoppers were pre-boiled in $\mathrm{NaOH}$ and rinsed with milli-Q water to remove trace hydrocarbons (OREMLAND and DES MARAIS, 1983). Fluid samples for $\mathrm{He}$ isotope analysis were transferred directly from the IGTs into evacuated aluminosilicate glass break-seal tubes and flamed off to seal ( $5 \mathrm{~g}$ fluid). Aliquots for $\mathrm{C}_{2}-\mathrm{C}_{4}$ hydrocarbons were 
transferred into sealed glass tubes fitted with Teflon and stainless valves (CRUSE and SEEWALD, 2006) for later determination of trace abundances at WHOI via a purge-and-trap device interfaced to molecular sieve $\mathrm{GC}$ with flame ionization detection. At WHOI, $\mathrm{Cl}$ abundances were determined by ion chromatography and $\mathrm{Mg}$ was determined on a ThermoElectron Element2 inductively coupled plasma mass spectrometer (ICP-MS).

Stable carbon isotopes $\left(\delta^{13} \mathrm{C}_{\mathrm{CO} 2}\right.$ and $\left.\delta^{13} \mathrm{C}_{\mathrm{CH} 4}\right)$ were measured at WHOI by isotope ratio monitoring-mass spectrometry using a Finnigan DeltaPlusXL mass spectrometer coupled to an Agilent $6890 \mathrm{GC}\left(1150^{\circ} \mathrm{C}\right.$ combustion temperature). Stable carbon isotope data are reported in standard delta notation $\left(\delta^{13} \mathrm{C}\right)$ expressed as:

$$
\delta^{13} \mathrm{C}(\%)=\left[\frac{R_{\text {samp }}-R_{\text {std }}}{R_{\text {std }}}\right] \times 1000
$$

where $R_{\text {samp }}$ and $R_{\text {std }}$ are the isotope ratios $\left({ }^{13} \mathrm{C} /{ }^{12} \mathrm{C}\right)$ of the sample and the standard, respectively. Carbon stable isotopes are reported relative to the Vienna PDB scale. Due to variable entrainment of ambient seawater that contains $2.25 \mathrm{mmol} / \mathrm{kg} \mathrm{CO}_{2}$ with a $\delta^{13} \mathrm{C}_{\mathrm{CO} 2}$ value of $1.1 \%$, reported sample $\delta^{13} \mathrm{C}_{\mathrm{CO} 2}$ values have been calculated from measured values using isotope mass balance (CRUSE and SEeWALD, 2006). Measured $\delta^{13} \mathrm{C}_{\mathrm{CH} 4}$ values reflect actual sample isotopic compositions, because seawater contains negligible quantities of $\mathrm{CH}_{4}$. Analytical uncertainties $(2 \sigma)$ in abundance and isotopic analyses are listed in Table 1.

Radiocarbon $\left({ }^{14} \mathrm{C}_{\mathrm{CO} 2}\right.$ and $\left.{ }^{14} \mathrm{C}_{\mathrm{CH} 4}\right)$ analysis was conducted at the WHOI National Ocean Sciences Accelerator Mass Spectrometry Facility (NOSAMS) (Table A1). Results are expressed in terms of Fraction Modern $\left(\mathrm{F}_{\mathrm{m}}\right)$, representing the deviation of the sample relative to the modern 
NBS Oxalic Acid I standard (NIST-SRM-4990, AD 1950) (Olsson, 1970). 'Corrected' CO 2 radiocarbon measurements (Table A1) remove the effects of entrainment of ambient seawater, with an isotopic mass balance approach that is analogous to the approach for $\delta^{13} \mathrm{C}_{\mathrm{CO} 2}$ (Vent fluid $[\mathrm{Mg}]$ as measured, East Summit fluid $\left[\mathrm{CO}_{2}\right]$ as measured, Ravelin $\# 2$ fluid $\left[\mathrm{CO}_{2}\right]$ assumes conservative endmember-seawater mixing, i.e. before $\mathrm{\Sigma HCOOH}$ formed, seawater $[\mathrm{Mg}]=52.4$ $\mathrm{mmol} / \mathrm{kg}$, seawater $\left[\mathrm{CO}_{2}\right]=2.25 \mathrm{mmol} / \mathrm{kg}$, seawater $\mathrm{F}_{\mathrm{m}}=0.9300(\sim 580$ years, estimated from 2500m depth, WOCE Caribbean line A22, 1997)). Corrected $\mathrm{CO}_{2}$ is also expressed in conventional radiocarbon age, which is calculated with a 5,568 year half life and is not corrected for reservoir fluctuations or calendar age (STUIVER, 1980; STUIVER and POLACH, 1977). Measured analytical uncertainties are listed in Table A1. Corrected $\mathrm{CO}_{2}$ uncertainties are conservative estimates calculated via error propagation of independent variables (e.g. also taking into account the effects of $[\mathrm{Mg}]$ and $\left[\mathrm{CO}_{2}\right]$ analytical uncertainties).

Samples were analyzed for He abundance and isotope composition in the Isotope Geochemistry Facility at WHOI (Table A2), where they were attached to a custom built ultrahigh-vacuum line via viton o-ring, and introduced into the line via a $0.75 \mathrm{~mL}$ aliquot. The gas was purified using charcoal at liquid nitrogen temperature, followed by active metal (SAES ST707) gettering at high and low temperature. Helium was cryogenically separated from the other noble gases (LOTT, 2001). The gas samples were automatically split on the extraction line using pre-measurement from a quadrupole mass spectrometer, typically by a factor of $\sim 1000$, to ensure that appropriate amounts were inlet. Splitting volumes were calibrated manometrically and were used to calculate concentrations. Helium concentrations and isotopic compositions were analyzed via magnetic sector mass spectrometry by comparison to air standards. The procedural line blank (including the viton o-ring) is $<1.5 \times 10^{-9} \mathrm{~mL} \mathrm{STP}{ }^{4} \mathrm{He}$. One full 
procedural blank, which included the sea-going extraction line and full storage time in the break seal tube, was $\sim 6 \times 10^{-9} \mathrm{~mL} \mathrm{STP}{ }^{4} \mathrm{He}$ (with atmospheric ${ }^{3} \mathrm{He} /{ }^{4} \mathrm{He}$ ). These blank levels are insignificant relative to the samples ( $<3 \%$ in all cases), as also indicated by the mantle values for

${ }^{3} \mathrm{He} /{ }^{4} \mathrm{He}$. Uncertainties for ${ }^{4} \mathrm{He}$ abundances are approximately $5 \%$ due to splitting procedures (Table A2).

\subsection{Calculation of endmember compositions}

An 'endmember' composition is calculated for the $226^{\circ} \mathrm{C}$ East Summit fluid following the common practice in hydrothermal chemistry of regressing individual chemical species to zero Mg content, based on studies that show near-quantitative Mg removal in high-temperature fluids (Table 1) (BISCHOFF and DiCKSON, 1975). In some cases (e.g. $\Sigma \mathrm{CO}_{2}$ ) lower temperature (21 to $151^{\circ} \mathrm{C}$ ) mixed fluids exhibit non-conservative behavior that is the result of processes occurring during mixing between an endmember fluid and seawater in the subsurface, prior to their expression at the seafloor as elevated-Mg fluids. Extrapolation to end-members would not be meaningful, thus non-conservative behavior in mixed fluids is considered in terms of measured abundances only.

\subsection{Assessment of $\mathrm{HCOOH}$ metastable equilibrium using chemical affinity}

The equilibrium state of the reaction:

$$
\mathrm{CO}_{2}+\mathrm{H}_{2}=\mathrm{HCOO}^{-}+\mathrm{H}^{+}
$$

in Von Damm mixed fluids can be assessed by calculating the chemical affinity $(A)$ : 


$$
A=-\Delta_{r} G=-R T \ln \left(Q_{r} / K_{e q}\right)
$$

where $R$ is the universal gas constant, $T$ is measured fluid temperature (Kelvin), $Q_{r}$ is the reaction quotient, and $K_{e q}$ is the equilibrium constant at $T$ and seafloor pressure (230 bar). At in situ $\mathrm{pH}$ calculated at seafloor pressure and sampled maximum temperature using SUPCRT thermodynamic data (JOHNSON et al., 1992; SHOCK, 1995) and EQ3/6 software (WOLERY, 1992; WOLERY and DAVELER, 1992) (5.7 to 5.9) it was assumed that measured $\Sigma \mathrm{HCOOH} \approx \mathrm{HCOO}^{-}$ concentrations, and that $\mathrm{HCOO}^{-}$activities are approximately equal to concentrations with an activity coefficient of 0.6 (calculated in EQ3/6). Measured volatile abundances were assumed to approximate activities (i.e. activity coefficients equal 1). 
Table A1. Radiocarbon data from Von Damm vent fluids.

\begin{tabular}{lcccccl}
\hline Vent & Sample & $\begin{array}{c}\text { Meas. } \mathbf{C H}_{\mathbf{4}} \\
\text { Fm }\end{array}$ & $\begin{array}{c}\text { Meas. } \mathbf{C O}_{2} \\
\text { Fm }\end{array}$ & $\begin{array}{c}\text { Corr. } \mathbf{C O}_{2} \\
\mathbf{F m ~}\end{array}$ & $\begin{array}{c}\text { Age Corr. CO } \\
\text { years }\end{array}$ & Accession \# \\
\hline East Summit & J2-612-IGT2 & $0.0064 \pm 13$ & $0.0660 \pm 15$ & $0.0251 \pm 46$ & 29585 & OS-104460 $\left(\mathrm{CH}_{4}\right)$, OS-105946 $\left(\mathrm{CO}_{2}\right)$ \\
East Summit & J2-616-IGT8 & $0.0056 \pm 13$ & $0.0712 \pm 50$ & $0.0373 \pm 69$ & 26410 & OS-104461 $\left(\mathrm{CH}_{4}\right)$, OS-104700 $\left(\mathrm{CO}_{2}\right)$ \\
Ravelin \#2 & J2-621-IGT2 & $0.0051 \pm 13$ & - & - & - & OS-104462 $\left(\mathrm{CH}_{4}\right)$ \\
Ravelin \#2 & J2-621-IGT8 & $0.0074 \pm 23$ & $0.3573 \pm 29$ & $0.0236 \pm 395$ & 30080 & OS-104706 $\left(\mathrm{CH}_{4}\right)$, OS-104344 $\left(\mathrm{CO}_{2}\right)$ \\
\hline
\end{tabular}

*'Fm', fraction modern 
Table A2. He data from Von Damm vent fluids.

\begin{tabular}{|c|c|c|c|c|c|c|c|c|c|}
\hline Vent & Sample & $\begin{array}{c}\text { Meas. }{ }^{3} \mathrm{He} /{ }^{4} \mathrm{He} \\
\mathrm{R} / \mathrm{Ra}\end{array}$ & $\begin{array}{l}\text { Meas. }{ }^{4} \mathrm{He} \\
\mathrm{mL} \mathrm{STP} / \mathrm{g}\end{array}$ & $\begin{array}{c}\text { Meas. }{ }^{4} \mathrm{He} \\
\mu \mathrm{mol} / \mathrm{kg}\end{array}$ & $\begin{array}{c}\text { Calc. }{ }^{3} \mathrm{He}^{*} \\
\mu \mathrm{mol} / \mathrm{kg}\end{array}$ & $\begin{array}{c}\text { Meas. } \mathrm{CH}_{4} \\
\mu \mathrm{mol} / \mathrm{kg}\end{array}$ & Meas. $\mathrm{CH}_{4} /{ }^{3} \mathrm{He}$ & $\begin{array}{l}{\text { Pred. } \mathrm{C}^{\dagger}}_{\mu \mathrm{mol} / \mathrm{kg}}\end{array}$ & $\begin{array}{c}\text { Meas. } \mathrm{CH}_{4} / \text { Pred. } \mathrm{C} \\
\% \text { converted }\end{array}$ \\
\hline East Summit & J2-616-IGT8 & $8.209 \pm 0.131$ & $2.477 \mathrm{E}-05$ & 1.01 & $1.147 \mathrm{E}-05$ & 2715 & $2.367 \mathrm{E}+08$ & 11473 & 0.24 \\
\hline Ravelin \#1 & J2-617-IGT6 & $8.265 \pm 0.133$ & $1.871 \mathrm{E}-05$ & 0.76 & $8.721 \mathrm{E}-06$ & 2020 & $2.316 \mathrm{E}+08$ & 8721 & 0.23 \\
\hline Ginger Castle & J2-617-IGT4 & $7.956 \pm 0.130$ & $1.785 \mathrm{E}-05$ & 0.73 & $8.012 \mathrm{E}-06$ & 1875 & $2.340 \mathrm{E}+08$ & 8012 & 0.23 \\
\hline
\end{tabular}

* Calculated from ${ }^{4} \mathrm{He}$ and $\mathrm{R} / \mathrm{Ra}$

† Predicted from ${ }^{3} \mathrm{He}$ and the standard magmatic $\mathrm{CO}_{2} /{ }^{3} \mathrm{He}$ value of $1 \times 10^{9}$ 

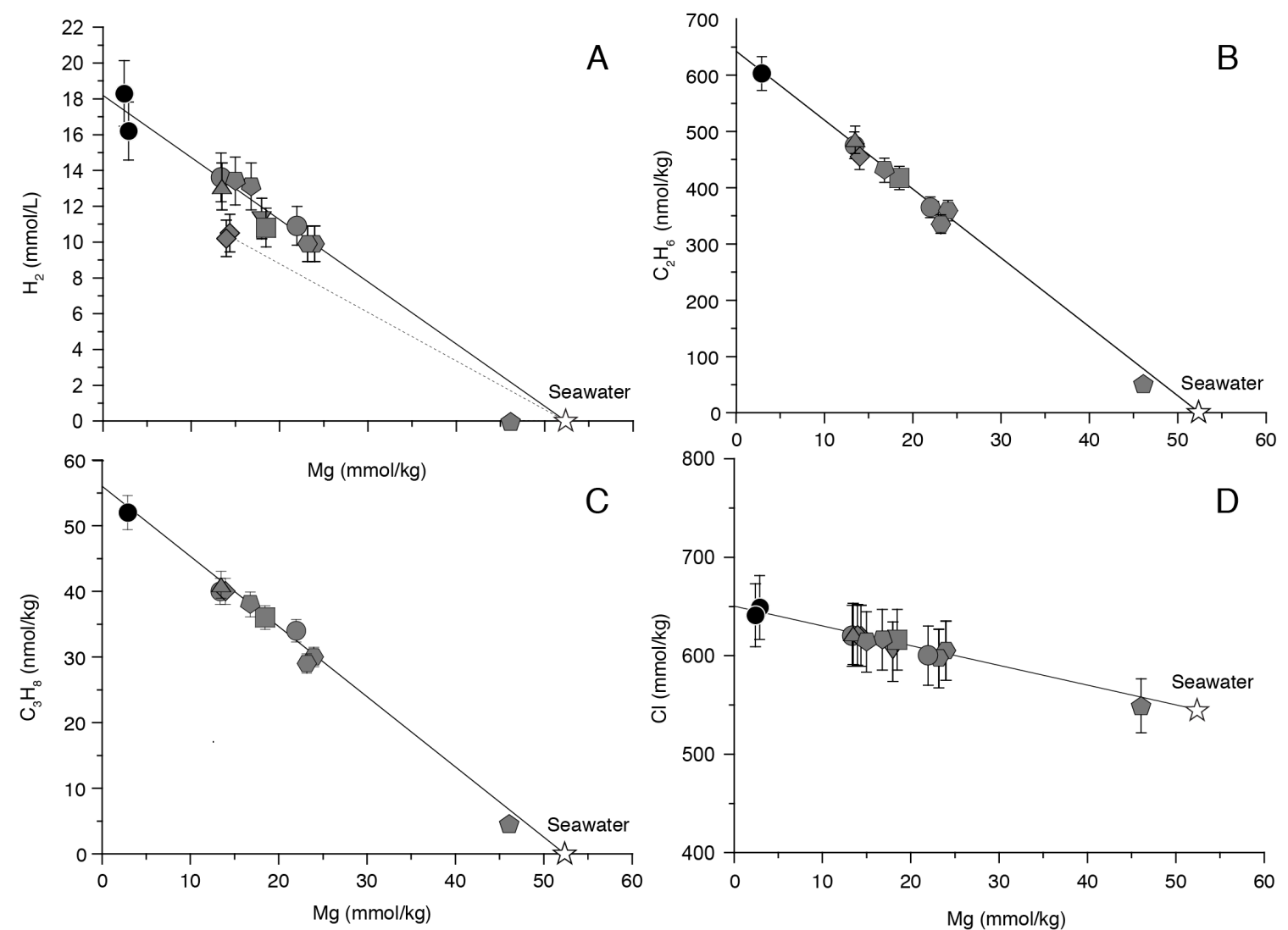

East Summit $\triangle$ White Castle $\nabla$ Ginger Castle

Figure A1. Plot of measured $\mathrm{Mg}$ versus measured $\mathrm{H}_{2}(\mathrm{~A}), \mathrm{C}_{2} \mathrm{H}_{6}(\mathrm{~B}), \mathrm{C}_{3} \mathrm{H}_{8}(\mathrm{C})$ and $\mathrm{Cl}$ (D). Conservative behavior in $\mathrm{Cl}, \mathrm{C}_{2} \mathrm{H}_{6}, \mathrm{C}_{3} \mathrm{H}_{8}$ as well as $\mathrm{CH}_{4}$ (see text), during mixing between endmember fluid (black circles) and seawater suggests that the Von Damm vent field is fed by a single source fluid originating in the high temperature reaction zone below the seafloor. Nonconservative $\mathrm{H}_{2}$ behavior occurs at two mixed fluid vents, Old Man Tree $\left(115^{\circ} \mathrm{C}\right)$ and Shrimp Hole $\left(21^{\circ} \mathrm{C}\right)$. These $\mathrm{H}_{2}$ depletions remain unexplained, even after taking into account the effect of $\Sigma \mathrm{HCOOH}$ formation, and potentially result from the generation of another transient, metastable species. 


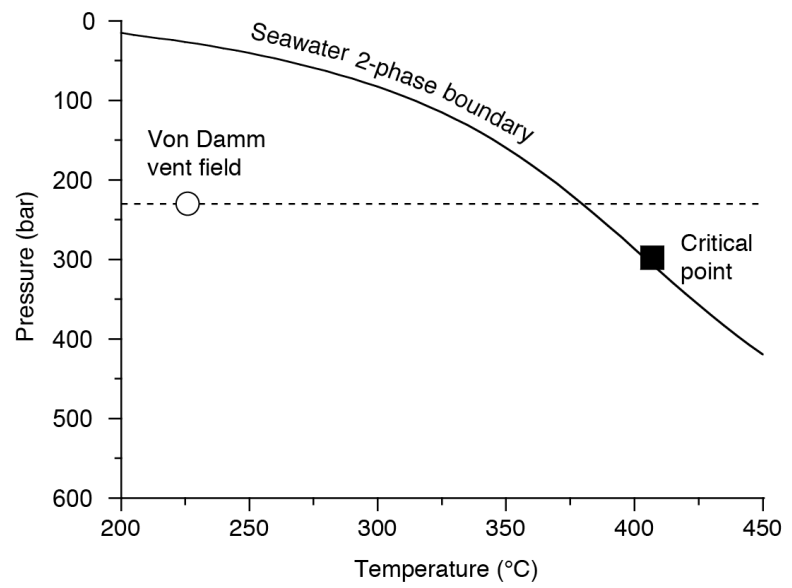

Figure A2. Plot of maximum sampled temperature and seafloor pressure conditions at the Von Damm vent field. The curve represents the 2-phase boundary of seawater (BISCHOFF and RosenbAUER, 1985). To attain measured temperatures, Von Damm fluids would have cooled by at least $150^{\circ} \mathrm{C}$ following phase separation. Therefore phase separation is unlikely to have occurred, and elevated $\mathrm{Cl}$ is more likely a result of hydration of olivine and removal of water from circulating fluids during serpentinization. 


\section{REFERENCES}

BisCHOFF, J.L., Dickson, F. (1975) Seawater-basalt interaction at $200^{\circ} \mathrm{C}$ and 500 bars: implications for origin of sea-floor heavy-metal deposits and regulation of seawater chemistry. Earth and Planetary Science Letters 25, 385-397.

BischOFF, J.L., RosenBAUER, R.J. (1985) An empirical equation of state for hydrothermal seawater $(3.2 \% \mathrm{NaCl})$. American Journal of Science 285, 725-763.

Cruse, A., SEewald, J. (2006) Geochemistry of low-molecular weight hydrocarbons in hydrothermal fluids from Middle Valley, northern Juan de Fuca Ridge. Geochimica et Cosmochimica Acta 70, 2073-2092.

Johnson, J., Oelkers, E., Helgesen, H. (1992) SUPCRT92: a software package for calculating the standard molal thermodynamic properties of minerals, gases, aqueous species, and reactions from 1 to 5000 bar and 0 to $1000^{\circ} \mathrm{C}$. Computational Geoscience 18, 899-947.

LOTT, D.E. (2001) Improvements in noble gas separation methodology: A nude cryogenic trap. Geochemistry Geophysics Geosystems 2(12), doi: 10.1029/2001GC000202.

OLSson, I. (1970) The use of oxalic acid as a standard, in: Olsson, I. (Ed.), Radiocarbon Variations and Absolute Chronology, Nobel Symposium, 12th Proc. John Wiley \& Sons, New York, p. 17.

Oremland, R.S., Des Marais, D.J. (1983) Distribution, abundance and carbon isotopic composition of gaseous hydrocarbons in Big Soda Lake, Nevada: an alkaline, meromictic lake. Geochimica et Cosmochimica Acta 47, 2107-2114.

Seewald, J.S., Doherty, K., Hammar, T., Liberatore, S. (2002) A new gas-tight isobaric sampler for hydrothermal fluids. Deep Sea Research Part I: Oceanographic Research Papers 49, 189-196.

SHOCK, E. (1995) Organic acids in hydrothermal solutions: standard molal thermodynamic properties of carboxylic acids and estimates of dissociation constants at high temperatures and pressures. American Journal of Science 295, 496-580.

Stuiver, M. (1980) Workshop on ${ }^{14} \mathrm{C}$ data reporting. Radiocarbon 22, 964-966.

Stuiver, M., Polach, H. (1977) Discussion: Reporting of ${ }^{14} \mathrm{C}$ data. Radiocarbon 19, 355-363.

Wolery, T.J. (1992) EQ3NR, A Computer Program for Geochemical Aqueous SpeciationSolubility Calculations: Theoretical Manual, User's Guide, and Related Documentation (Version 7.0). Lawrence Livermore National Lab. 
Wolery, T.J., DAveler, S.A. (1992) EQ6, A Computer Program for Reaction Path Modeling of Aqueous Geochemical Systems: Theoretical Manual, User's Guide, and Related Documents. Lawrence Livermore National Lab. 


\title{
Chapter 3
}

\section{Geochemistry of deep-sea hydrothermal fluids from the Von Damm vent field, Mid-Cayman Rise, Caribbean Sea}

\begin{abstract}
Hosted on the Mount Dent oceanic core complex in the Mid-Cayman Rise, the Von Damm deep-sea vent field expands the known range of hydrothermal fluid compositions. The intermediate temperature of venting at the Von Damm vent field contrasts with the lowtemperature fluids and carbonate chimneys of Lost City and the high-temperature fluids and metal-rich black smokers of Rainbow and Logatchev. High- $\mathrm{H}_{2}$ fluids vent at a maximum temperature of $226^{\circ} \mathrm{C}$, providing an opportunity to examine carbon transformations occurring in a novel temperature regime in a highly reducing system. Von Damm fluid geochemistry reflects a distinctly different set of conditions compared to the few well-characterized submarine hydrothermal systems invoked to also reflect significant ultramafic influence. To investigate the role of substrate composition and deep fluid circulation conditions on fluid chemistry, the abundance and isotopic composition of organic, inorganic, and dissolved volatile species in vent fluids at Von Damm were examined in samples collected in 2012 and 2013. The inorganic geochemistry of circulating fluids is indicative of moderate temperature $\left(<250^{\circ} \mathrm{C}\right)$ sequential
\end{abstract}


peridotite-gabbro water/rock reaction. Serpentinization of an olivine-rich host rock generates high- $\mathrm{H}_{2}$ fluids that contain dissolved $\mathrm{CH}_{4}, \mathrm{C}_{2} \mathrm{H}_{6}, \mathrm{C}_{3} \mathrm{H}_{8}, \mathrm{n}-\mathrm{C}_{4} \mathrm{H}_{10}$, and $\mathrm{i}-\mathrm{C}_{4} \mathrm{H}_{10}$ with abundances and isotope signatures similar to those observed at other ultramafic hosted systems. Abundant $\mathrm{C}_{6} \mathrm{H}_{6}$ was also detected in the fluids. Inorganic water/rock ratio considerations based on $\mathrm{Rb}, \mathrm{Li}$, and Sr isotopes and chemical equilibrium modeling of carbon species support plutonic hosted, high-carbon, high- $\mathrm{H}_{2}$ gas inclusions as the putative source for these hydrocarbons. Geochemical modeling confirms the interpretation that mixing between vent fluids and seawater can precipitate the talc and $\mathrm{SiO}_{2}$ assemblage that is associated with active venting at the Von Damm hydrothermal field.

\section{INTRODUCTION}

Ultraslow spreading mid ocean ridges (MORs) $\left(<20 \mathrm{~mm} \mathrm{yr}^{-1}\right.$ full rate) constitute one quarter of the nearly 55,000 km global ridge system (SINHA and EVANS, 2004), and remain one of the frontiers for hydrothermal vent exploration. An early hypothesis suggested that ultraslow ridges may lack sufficient magma supply to drive fluid circulation (BAKER et al., 1996), however, following the discovery of active hydrothermal plumes and black smoker venting on the Southwest Indian Ridge and the Gakkel Ridge (BACH et al., 2002; GERMAN et al., 1998; EDMONDS et al., 2003; TAO et al., 2011; BoETIUS et al., in press), this hypothesis has since been disproven. It is now known that ultraslow spreading ridges host a spatial frequency of vents that is higher than predictions based on spreading rate and magma budget alone, suggesting that they are more efficient at supporting hydrothermal venting than fast spreading ridges (BAKER et al., 2004; BAKER and German, 2004; BeAulieu et al., 2013).

The exposure of lower crustal and mantle-derived lithologies at slow and ultraslow 
MORs results in a rich diversity of hydrothermal fluid compositions due to the variety of possible substrates for water-rock reaction (DICK et al., 2003). For example, vent fields along the slow spreading Mid-Atlantic Ridge (MAR) range from basalt-hosted high-temperature $\left(>300^{\circ} \mathrm{C}\right)$ systems at TAG, $26^{\circ} \mathrm{N}$; Lucky Strike, $37^{\circ} 17^{\prime} \mathrm{N}$ and Menez Gwen, $37^{\circ} 50^{`} \mathrm{~N}$, to ultramafic/gabbro-hosted high-temperature systems at Rainbow, $36^{\circ} \mathrm{N}$; Logatchev, $14^{\circ} \mathrm{N}$; Ashadze, $13^{\circ} \mathrm{N}$ and ultramafic-hosted low-temperature $\left(<300^{\circ} \mathrm{C}\right)$ vents at Lost City, $30^{\circ} \mathrm{N}$ (EDMONDS, 2010). Vent fluid chemistry has been characterized at only one ultraslow spreading system, the sedimented, possibly ultramafic-influenced Loki's Castle vent field on the Knipovich Ridge (PEDERSEN et al., 2010). Towed sensor surveys throughout the 1980s and 1990s identified pervasive high $\mathrm{CH}_{4} / \mathrm{Mn}$ ratios in advecting hydrothermal plumes along the MAR (BoUGAULT et al., 1998; Charlou et al., 1988; CHARlou et al., 1998). These high $\mathrm{CH}_{4} / \mathrm{Mn}$ ratios are thought to result from hydrothermal fluid-driven serpentinization of ultramafic rocks (peridotite) occurring at lower temperatures at the seafloor. Although these $\mathrm{CH}_{4}$-rich hydrothermal systems are likely to impart important effects on ocean chemistry, such vents have proved challenging to locate using traditional in situ sensing techniques due to the low particulate nature of their plumes.

Fluids rich in dissolved $\mathrm{H}_{2}$, such as those generated during serpentinization of ultramafic rocks, are of interest due to thermodynamic drives for the abiotic reduction of dissolved inorganic carbon $\left(\Sigma \mathrm{CO}_{2}=\mathrm{CO}_{2}+\mathrm{HCO}_{3}{ }^{-}+\mathrm{CO}_{3}{ }^{2-}\right)$ to organic compounds. In circulating deep-sea hydrothermal systems, these reactions are predicted to occur under lower temperature $\left(<350^{\circ} \mathrm{C}\right)$ H2-rich conditions (MCCOLlOM, 2003; SEEWALd et al., 2006; SHOCK, 1990, 1992; SHOCK and SCHULTE, 1998). The origin of organic compounds such as $\mathrm{CH}_{4}$ in vent fluids has been of interest since the discovery of seafloor hydrothermal systems (CORLISS et al., 1979; WELHAN, 
1988), and the potential for abiotic organic synthesis has sparked speculation regarding its role in the origin of life on Earth (MARTIN et al., 2008; NiSBET and SLEEP, 2001; RUSSELL et al., 2010), and has implications for the metabolic processes of present-day microbial populations in vent ecosystems (AmEND et al., 2011; Kelley et al., 2002; MCCOLlOM, 2007). In ultraslow spreading systems such as the Mid-Cayman Rise, water-rock reaction between circulating hydrothermal fluids and exhumed mafic deep crustal and ultramafic mantle rocks can generate significant amounts of $\mathrm{H}_{2}$ from oxidation of the ferrous component of olivine. Putative abiotic synthesis of $\mathrm{CH}_{4}$ and other hydrocarbons has been identified in ultramafic-influenced hydrothermal fields such as Lost City (PROSKUROWSKI et al., 2008) and Rainbow (CHARLOU et al., 2002), however questions remain regarding the spatial, temporal, and mechanistic nature of carbon transformation reactions.

The Von Damm vent field was located in 2010 using a combination of the AUTOSUB Autonomous Underwater Vehicle and HYBIS towed camera system (CONNELLY et al., 2012), following the identification of several hydrothermal plumes emanating from the Mid-Cayman Rise (MCR) (GERMAN et al., 2010). At Von Damm, high- $\mathrm{H}_{2}$ fluids vent at a maximum temperature of $226^{\circ} \mathrm{C}$, providing an exciting opportunity to examine abiotic carbon transformations occurring in a novel temperature regime in a highly reducing system. The intermediate temperature of venting at the Von Damm vent field and the hydrothermal mound composition reflect a distinctly different set of conditions relative to the low-temperature fluids and carbonate chimneys of Lost City and the high-temperature fluids and metal-rich black smokers of Rainbow (Kelley et al., 2001; CHARLOU et al., 2002; DouviLle et al., 2002). This study investigated the chemical and isotopic composition of vent fluids at the Von Damm vent 
field to elucidate the role of substrate composition and deep fluid circulation conditions in controlling the abundance of organic, inorganic, and dissolved volatile species.

\section{GEOLOGIC SETTING AND DESCRIPTION OF SAMPLING SITES}

The Von Damm vent field is located at $18^{\circ} 22.6^{\prime} \mathrm{N}$ and $81^{\circ} 47.9^{\prime} \mathrm{W}$ at a depth of $2291 \mathrm{~m}$ to $2387 \mathrm{~m}$ on Mount Dent, an oceanic core complex situated on the west flank of the ultraslow spreading MCR (15-17 $\mathrm{mm} \mathrm{yr}^{-1}$ full spreading rate, ROSENCRANTZ et al., 1988; HAYMAN et al., 2011) (Fig. 1A and 1B). Oceanic core complexes are uplifted exposures of lower crustal and upper mantle rocks that have been exhumed from depth by long-lived tectonic extension, and their occurrence at slow and ultraslow spreading ridges provides a range of possible substrates for fluid-rock reaction (CANN et al., 1997; CANNAT, 1993 (TUCHOLKE et al., 1998)). Early dredging and submersible sampling of the upper slopes of Mount Dent indicate a dominance of gabbroic and peridotite outcrops, with less prevalent basalt (BALLARD et al., 1979; STROUP and Fox, 1981). The Von Damm site was previously reported to be $13 \mathrm{~km}$ off-axis, relative to the deep rift basin (CONNELLY et al., 2012). However, recent study of high-resolution bathymetry and direct seafloor observations suggest that the oceanic core complex may be undergoing incipient rifting resulting in Von Damm being located atop high-angle normal faults that overlie the present-day spreading axis (CHEADLE et al., 2012). Incipient rifting could provide a source

of heat to the base of the system, with hydrothermal circulation mining heat from the underlying host rocks, via downward propagating cracks and/or along fault zones as is proposed at other slow spreading ridges (FonTAINE et al., 2008, 2014; LISTER, 1974, 1982; MCCAIG et al., 2007). Other possible heat sources that may also contribute to drive hydrothermal circulation at Von Damm include cooling of gabbroic intrusions and exothermic serpentinization reactions 
(GERMAN and Lin, 2004; Lowell, 2013). At Von Damm, clear, particle-poor hydrothermal fluids vent from the summit and flanks of a $150 \mathrm{~m}$ diameter, $60 \mathrm{~m}$ tall cone and along a lowrelief spur that extends $250 \mathrm{~m}$ SSE from the cone summit (Fig. 1B).

\section{MethodS}

\subsection{Sample Collection}

All fluid samples were collected using $150 \mathrm{~mL}$ titanium isobaric gas-tight (IGT) samplers (SEEWALD et al., 2002) deployed by the ROV Jason II during R/V Atlantis cruise AT18-16 in January 2012 and by the HROV Nereus during R/V Falkor cruise FK008 in June 2013. Fluid temperatures were monitored continuously during sampling with attached thermocouples aligned with inlet snorkel tips. Thermocouples were calibrated with a National Institute of Standards and Technology (NIST) temperature calibrator, and the maximum measured temperature for each sample is reported $\left( \pm 2^{\circ} \mathrm{C}\right)$ (Table 1). Due to variability in dive duration, 5-20 hours elapsed between sampling on the seafloor and sample processing.

During sample processing, aliquots were extracted for shipboard analysis of $\mathrm{pH}\left(25^{\circ} \mathrm{C}\right)$ and total dissolved sulfide $\left(\Sigma \mathrm{H}_{2} \mathrm{~S}=\mathrm{H}_{2} \mathrm{~S}+\mathrm{HS}^{-}+\mathrm{S}^{2-}\right), \mathrm{CH}_{4}$, and $\mathrm{H}_{2}$, and shore-based analysis of other major species ( $\mathrm{Na}, \mathrm{Cl}, \mathrm{Mg}, \mathrm{Ca}, \mathrm{K}, \mathrm{SiO}_{2}, \mathrm{SO}_{4}, \mathrm{Br}$ ), minor species (Fe, $\mathrm{Mn}, \mathrm{Li}, \mathrm{Sr}, \mathrm{Rb}$ ), and volatiles, including total inorganic carbon $\left(\Sigma \mathrm{CO}_{2}=\mathrm{CO}_{2}+\mathrm{HCO}_{3}{ }^{-}+\mathrm{CO}_{3}{ }^{2-}\right)$ and trace hydrocarbons $\left(\mathrm{C}_{2} \mathrm{H}_{6}, \mathrm{C}_{3} \mathrm{H}_{8}, \mathrm{n}-\mathrm{C}_{4} \mathrm{H}_{10}, \mathrm{i}-\mathrm{C}_{4} \mathrm{H}_{10}\right.$, and $\left.\mathrm{C}_{6} \mathrm{H}_{6}\right)$. Fluid aliquots for major and minor species, metals and $\mathrm{SiO}_{2}$, and $\mathrm{SO}_{4}$ were transferred to separate acid-washed high-density polyethylene (HDPE) Nalgene ${ }^{\mathrm{TM}}$ bottles. Aliquots for metals and $\mathrm{SiO}_{2}$ were immediately acidified to $\mathrm{pH}<2$ with concentrated Optima ${ }^{\mathrm{TM}} \mathrm{HCl}$, while major and minor species and $\mathrm{SO}_{4}$ aliquots were not acidified. Aliquots were collected for $\mathrm{SO}_{4}$ by sparging untreated fluid with $\mathrm{N}_{2}$ 
( $\sim 20 \mathrm{~min}$ ) to remove $\mathrm{H}_{2} \mathrm{~S}$ that may oxidize during storage and elevate $\mathrm{SO}_{4}$ abundances. Aliquots for $\Sigma \mathrm{CO}_{2}$ were transferred to evacuated serum vials with $\mathrm{NaOH}$-boiled butyl rubber stoppers (OREMLAND and Des MARAIS, 1983), while those for trace hydrocarbons were transferred into evacuated glass tubes fitted with Teflon and stainless gas-tight valves.

Following the completion of fluid sample processing, the sample chamber of each IGT was rinsed with Milli-Q water and high-purity acetone to collect a 'dregs' fraction that contains any precipitates that may have formed as a result of cooling or mixing within the sampler. The dregs fraction particles were collected by vacuum filtration on $0.22 \mu \mathrm{m}$ pore size, $44 \mathrm{~mm}$ diameter Nylon filters, dried, and stored. Small amounts of precipitates formed during storage of acidified metals aliquots at WHOI, thus the 'bottle filter fraction' was separated from the aqueous sample by filtration using acid-washed HDPE syringes equipped with removable 0.22 $\mu \mathrm{m}$ pore size, $22 \mathrm{~mm}$ diameter Nucleopore ${ }^{\mathrm{TM}}$ filters. The bottle filter fraction filters were stored in acid-washed $30 \mathrm{~mL}$ Teflon Savillex ${ }^{\mathrm{TM}}$ vials prior to digestion. In the shore-based lab at WHOI, dregs fraction particles and filters were quantitatively transferred to $30 \mathrm{~mL}$ Teflon Savillex ${ }^{\mathrm{TM}}$ vials by rinsing with Optima ${ }^{\mathrm{TM}}$ methanol, and then evaporated to dryness in a tracemetal clean hood. Both the bottle filter and dregs fraction particles were separated from their filters by soaking in $5 \mathrm{~mL}$ of reverse aqua regia $\left(1: 3 \mathrm{HCl}: \mathrm{HNO}_{3}\right)$ in $30 \mathrm{~mL}$ Savillex ${ }^{\mathrm{TM}}$ vials overnight. To digest particulates, the vials were heated open at $70^{\circ} \mathrm{C}$ until the particles dissolved, and the aqua regia was evaporated to near dryness. The digestion and dry down process was repeated three times to ensure complete digestion. Digested residues were then brought back up in $5 \% \mathrm{Optima}^{\mathrm{TM}} \mathrm{HNO}_{3}$ prior to analysis. 


\subsection{Analytical methods}

\subsection{1 $\mathrm{pH}$ and volatiles}

Species abundances determined at sea are reported in units of $\mu \mathrm{mol} / \mathrm{L}$ or $\mathrm{mmol} / \mathrm{L}$ fluid, while those determined on shore are reported in units of nmol/ $\mathrm{kg}, \mu \mathrm{mol} / \mathrm{kg}$ or $\mathrm{mmol} / \mathrm{kg}$ (Tables $1,2,3$, and 5). Immediately after withdrawing a fluid aliquot from the IGT sampler, $\mathrm{pH}\left(25^{\circ} \mathrm{C}, 1\right.$ atm) was measured onboard ship by potentiometry using a $\mathrm{Ag} / \mathrm{AgCl}$ combination reference electrode. $\mathrm{H}_{2}$ and $\mathrm{CH}_{4}$ abundances were analyzed shipboard by gas chromatography (GC) using a $5 \AA$ molecular sieve packed column and thermal conductivity detection after headspace extraction in a gastight syringe. Trace $\mathrm{C}_{2} \mathrm{H}_{6}, \mathrm{C}_{3} \mathrm{H}_{8}, \mathrm{n}-\mathrm{C}_{4} \mathrm{H}_{10}, \mathrm{i}-\mathrm{C}_{4} \mathrm{H}_{10}$, and $\mathrm{C}_{6} \mathrm{H}_{6}$ abundances were determined at WHOI via a purge-and-trap device interfaced to a gas chromatograph equipped with a HaySep-Q packed column and a flame ionization detector (CRUSE and SEEWALD, 2006) (For blanks and further method details, see Appendix). Dissolved $\Sigma \mathrm{H}_{2} \mathrm{~S}$ was determined shipboard by iodometric starch titration of an aliquot drawn into a gastight syringe (AMERICAN Public Health Assocation, 1980) as described in Von Damm (2000). Dissolved $\Sigma \mathrm{H}_{2} \mathrm{~S}$ was also precipitated as $\mathrm{Ag}_{2} \mathrm{~S}$ in $5 \mathrm{wt} \% \mathrm{AgNO}_{3}$ and stored for later gravimetric abundance determination. On shore, $\mathrm{Ag}_{2} \mathrm{~S}$ was filtered onto $0.22 \mu \mathrm{m}$ pore size, $25 \mathrm{~mm}$ diameter Nylon filters, weighed, and stored in glass vials for multiple sulfur isotope analysis. Reported $\Sigma \mathrm{H}_{2} \mathrm{~S}$ abundances are an average of results from the titration and gravimetric methods for 2012 samples and titration results only for 2013 samples. The analytical uncertainty $(2 \sigma)$ was \pm 0.05 units for $\mathrm{pH}\left(25^{\circ} \mathrm{C}, 1 \mathrm{~atm}\right), \pm 5 \%$ for $\mathrm{H}_{2}, \mathrm{CH}_{4}, \mathrm{C}_{2} \mathrm{H}_{6}$, and $\mathrm{C}_{3} \mathrm{H}_{8}$ and $\pm 10 \%$ for $\mathrm{n}-\mathrm{C}_{4} \mathrm{H}_{10}, \mathrm{i}-\mathrm{C}_{4} \mathrm{H}_{10}$, $\mathrm{C}_{6} \mathrm{H}_{6}$, and $\Sigma \mathrm{H}_{2} \mathrm{~S}$. 


\subsubsection{Major and minor elements and metals}

Major and minor element and metal concentrations were determined at WHOI by ion chromatography (IC) using a Dionex DX-500 (Na, Cl, Ca, K, Li, $\left.\mathrm{SO}_{4}, \mathrm{Br}\right)$ and by inductively coupled plasma mass spectrometry (ICP-MS) using a Thermo-Electron Element2 ( $\mathrm{Mg}, \mathrm{SiO}_{2}, \mathrm{Sr}$, $\mathrm{Rb}, \mathrm{Fe}, \mathrm{Mn}, \mathrm{Cu}, \mathrm{Zn}, \mathrm{Al}$ ). During both IC and ICP-MS analyses, samples were bracketed with NIST-traceable external standards. For trace metals ( $\mathrm{Fe}, \mathrm{Mn}, \mathrm{Cu}, \mathrm{Zn}, \mathrm{Al})$ that precipitate upon cooling in the samplers and storage bottles, data in Table 1 are the combined total of 'aqueous,' 'bottle-filter' and 'dregs' fraction analyses, and represent a reconstitution of the original sample

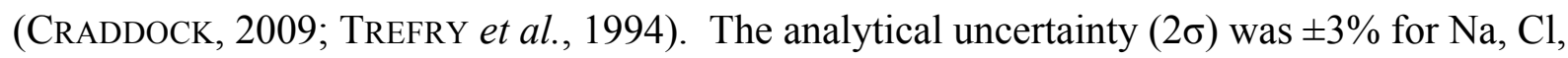
$\mathrm{Ca}, \mathrm{K}, \mathrm{SO}_{4}, \mathrm{Mg}, \mathrm{SiO}_{2}, \pm 5 \%$ for $\mathrm{Li}, \mathrm{Sr}, \mathrm{Rb}, \mathrm{Fe}, \mathrm{Mn}, \mathrm{Cu}, \mathrm{Zn}$, and $\mathrm{Al}$ and $\pm 10 \%$ for $\mathrm{Br}$. See Appendix for further details pertaining to ICP-MS analysis.

\subsubsection{Isotopes}

Stable $\delta^{13} \mathrm{C}$ carbon isotope analysis of $\mathrm{CH}_{4}, \mathrm{C}_{2} \mathrm{H}_{6}, \mathrm{C}_{3} \mathrm{H}_{8}$, and $\mathrm{C}_{6} \mathrm{H}_{6}$ was conducted at WHOI by isotope ratio monitoring-mass spectrometry using a Finnigan DeltaPlusXL mass spectrometer coupled to an Agilent 6890 gas chromatograph with an AT-Q column $\left(1150^{\circ} \mathrm{C}\right.$ combustion temperature). Fluids were made alkaline with $\mathrm{NaOH}$ for $\mathrm{CH}_{4}, \mathrm{C}_{2} \mathrm{H}_{6}, \mathrm{C}_{3} \mathrm{H}_{8}$, and $\mathrm{C}_{6} \mathrm{H}_{6}$ just prior to analysis, which was performed via serum vial headspace injection for $\mathrm{CH}_{4}$ and via a purge-and-trap device for $\mathrm{C}_{2} \mathrm{H}_{6}, \mathrm{C}_{3} \mathrm{H}_{8}$, and $\mathrm{C}_{6} \mathrm{H}_{6}$.

Multiple sulfur isotope analysis was conducted on dissolved $\Sigma \mathrm{H}_{2} \mathrm{~S}$ in select samples

$\left(\delta^{34} \mathrm{~S}, \delta^{33} \mathrm{~S}, \delta^{36} \mathrm{~S}\right)$ at MIT via isotope ratio mass spectrometry following methods in Ono et al. (2006). Approximately 1 to $2 \mathrm{mg} \mathrm{Ag}_{2} \mathrm{~S}$ was reacted under $\mathrm{F}_{2}$ overnight ( $\sim 40$ torr, $300^{\circ} \mathrm{C}, 12+\mathrm{h}$ ), 
and the product $\mathrm{SF}_{6}$ was purified by gas chromatography prior to isotope ratio analysis by a Thermo-Electron MAT 253.

Carbon and sulfur stable isotope data for the isotope of interest, $A$, are reported in standard delta notation $(\delta A)$ expressed as:

$$
\delta A(\%)=\left[\frac{R_{S}-R_{S T D}}{R_{S T D}}\right] \times 1000
$$

where $R_{S}$ and $R_{S T D}$ are the isotope ratios $\left({ }^{13} \mathrm{C} /{ }^{12} \mathrm{C},{ }^{33} \mathrm{~S} /{ }^{32} \mathrm{~S},{ }^{34} \mathrm{~S} /{ }^{32} \mathrm{~S},{ }^{36} \mathrm{~S} /{ }^{32} \mathrm{~S}\right)$ of the sample and the standard, respectively (Tables 1 and 4). Carbon and sulfur stable isotopes are reported relative to the Vienna PDB and Vienna CDT scales, respectively. The pooled standard deviation $(2 \sigma)$ was $\pm 0.8 \%$ for $\delta^{13} \mathrm{C}_{\mathrm{CH} 4}$, and the instrumental analytical uncertainty $(2 \sigma)$ was $\pm 0.4 \%$ for $\delta^{13} \mathrm{C}_{\mathrm{C} 2 \mathrm{H} 6}$, $\pm 0.7 \%$ or for $\delta^{13} \mathrm{C}_{\mathrm{C} 3 \mathrm{H} 8}$ and $\delta^{13} \mathrm{C}_{\mathrm{C} 6 \mathrm{H} 6}$, and $\pm 0.3 \%$ or for $\delta^{34} \mathrm{~S}_{\mathrm{H} 2 \mathrm{~s}}$. Sulfur isotope data are additionally expressed in $\Delta^{33} \mathrm{~S}$ notation ( $2 \sigma$ uncertainties in Table 1$)$, defined as the deviation of the minor isotope ratio from the terrestrial fractionation reference line (GAO and THIEMENS, 1991):

$$
\Delta^{33} \mathrm{~S}=\delta^{33} \mathrm{~S}-0.515 \times \delta^{34} \mathrm{~S}
$$

Strontium isotopic analysis was conducted on select samples at WHOI. Conventional ion-exchange procedures with $\mathrm{Sr}$ Spec resin (Eichrom, 100-150 $\mu \mathrm{m}$ ) were used, and ${ }^{87} \mathrm{Sr} /{ }^{86} \mathrm{Sr}$ isotope ratios were measured with a ThermoFinnigan NEPTUNE multi-collector inductively coupled plasma-mass spectrometer as described in Voss et al. (2014). The internal precision for Sr isotopic measurements is \pm 0.000010 
(2б). The external precision, after correction to values for NBS987 (0.710240) is \pm 0.000025 .

Corrections for potential $\mathrm{Rb}$ and $\mathrm{Kr}$ interferences are described by JACKSON AND HART (2006).

\subsection{Calculation of endmember fluid compositions}

Experimental and theoretical studies show that hydrothermal fluids undergo nearly quantitative removal of $\mathrm{Mg}$ and $\mathrm{SO}_{4}$ during fluid-rock reaction with basalt and gabbro (BISCHOFF and Dickson, 1975; MotTl and Holland, 1978; SeYfried and Bischoff, 1981) and with peridotite (JANECKY and SEYFRIED, 1986; SEYFRIED et al., 2007) at high temperatures and low water/rock ratios. The snorkel and $\sim 4 \mathrm{~mL}$ dead-volume of the IGT samplers are filled with $\mathrm{Mg}$ rich bottom seawater, thus seawater always comprises some fraction of a vent fluid sample. In addition, occasional accidental entrainment can occur during sample collection. Vent fluids can also undergo mixing with seawater either in the shallow seafloor subsurface or within the chimney structure prior to venting at the seafloor, and in these cases elevated Mg contents in sampled fluids reflect real venting fluid compositions. Thus, sampled fluid compositions are

typically assumed to reflect two-component mixing of a zero-Mg 'endmember' fluid with bottom seawater.

Dissolved $\mathrm{SO}_{4}$ and $\mathrm{Mg}$ abundances at Von Damm extrapolate to zero together within error (Fig. $2 \mathrm{~A}$ ), and the $\mathrm{Mg} / \mathrm{SO}_{4}$ ratio is near seawater, emphasizing that both species are likely seawater-derived (Table 1) (Von DAMM et al., 1985). To correct for seawater entrainment and/or seawater added to fill the sampler dead volume, endmember abundances for each vent are calculated via least-squares regression of an individual conservative chemical species versus $\mathrm{Mg}$ for all samples collected from a given vent orifice, weighted to pass through the background seawater composition and extrapolated to $0 \mathrm{mmol} / \mathrm{kg} \mathrm{Mg}$. Due to non-conservative behavior 
with mixing, endmember $\mathrm{pH}$ is not calculated by extrapolation. The reported $\mathrm{pH}\left(25^{\circ} \mathrm{C}\right)$ values represent the minimum measured value that typically corresponded to the lowest $\mathrm{Mg}$ fluid.

Endmember ${ }^{86} \mathrm{Sr} /{ }^{87} \mathrm{Sr}$ values are calculated by regression to a zero molar $\mathrm{Mg} / \mathrm{Sr}$ ratio (ALBARÈDE et al., 1981).

\section{RESUlts}

A maximum temperature of $226^{\circ} \mathrm{C}$ was measured in fluids collected from an $8 \mathrm{~m}$ tall spire at the mound summit (East Summit) (Fig. 1). Other sampled fluids ranged between $114^{\circ} \mathrm{C}$ to $151^{\circ} \mathrm{C}$ (West Summit, White Castle, Ginger Castle, Old Man Tree, Ravelin \#1, Ravelin \#2, Arrow Loop \#1, Twin Peaks, Bartizan) and a single lower temperature $21^{\circ} \mathrm{C}$ fluid was also collected (Shrimp Hole). Ideally, two fluid samples were collected at each individual vent site, however in four cases only one sample was successfully recovered, yielding a total of 20 fluid samples collected from 12 discrete vents (Table 1). The highest temperature East Summit fluid was resampled in 2013, however, due to navigation precision limitations, the exact location of the venting orifice likely differs from that sampled in 2012.

\subsection{Non-volatile aqueous species and $\mathrm{pH}$}

Measured $\mathrm{Mg}$ contents ranged from $2.43 \mathrm{mmol} / \mathrm{kg}$ in the highest temperature East Summit fluid in 2012 to near seawater $(46.1 \mathrm{mmol} / \mathrm{kg})$ in the lowest temperature Shrimp Hole fluid in 2012 (Table 1). The $\sim 4 \mathrm{~mL}$ dead volume within the IGT samplers (SEEwALD et al., 2002 ) is pre-filled with ambient bottom seawater, and can contribute a maximum of $\sim 1.4$ $\mathrm{mmol} / \mathrm{kg} \mathrm{Mg}$ to the sampled fluid. High temperature fluid $\mathrm{Mg}$ contents that are slightly higher than $1.4 \mathrm{mmol} / \mathrm{kg}$ are potentially due to subsurface mixing with seawater, a non-zero $\mathrm{Mg}$ 
endmember, or a minor degree of accidental seawater entrainment. In many cases for lower temperature fluids, both samples from a discrete vent had similar temperature and $\mathrm{Mg}$ content (Table 1), indicating that $\mathrm{Mg}$ was added during subsurface mixing with seawater prior to venting, rather than introduced by inadvertent seawater entrainment during sampling. In some cases $\mathrm{Mg}$ differs between a pair of samples from one vent, suggesting that the higher Mg sample was subject to accidental seawater entrainment during sampling, and thus the sample containing lower $\mathrm{Mg}$ is more representative of the venting fluid composition. Fluid $\mathrm{SO}_{4}$ abundances decrease linearly with respect to $\mathrm{Mg}$ to approximately zero abundance in the endmember fluid, within error, and all samples fall on a conservative mixing line (Fig. 2A). All vents sampled at Von Damm are consistent with a seawater origin for both $\mathrm{Mg}$ and $\mathrm{SO}_{4}$ (Table 1).

Fluids at Von Damm are characterized by higher chlorinities than seawater, with endmember $\mathrm{Cl}$ concentrations ranging from 635 to $655 \mathrm{mmol} / \mathrm{kg}$ that correspond to an enrichment of $\sim 19 \%$ relative to seawater (Fig. 2B). Endmember Na concentrations varied from 597 to $613 \mathrm{mmol} / \mathrm{kg}$ corresponding to an enrichment of $\sim 29 \%$ relative to seawater (Fig. 3A). Greater enrichments relative to seawater are observed in endmember $\mathrm{Ca}$, which ranges from 15.1 to $16.8 \mathrm{mmol} / \mathrm{kg}$ ( 48\%) (Fig. 3B), and endmember K, ranging from 16.3 to $17.4 \mathrm{mmol} / \mathrm{kg}$ ( 62\%) (Fig. 3C). Dissolved $\mathrm{SiO}_{2}$ is highly enriched relative to seawater with endmember concentrations ranging from 7.31 to $7.80 \mathrm{mmol} / \mathrm{kg}$ (Fig. 3D). Fluids are also highly enriched in the alkali metals $\mathrm{Li}$ and $\mathrm{Rb}$, with endmember abundances ranging from 190 to $219 \mu \mathrm{mol} / \mathrm{kg}$ (Fig. 3E) and 5.56 to $5.64 \mu \mathrm{mol} / \mathrm{kg}$ (Fig. 3F), respectively. Endmember $\mathrm{Br}$ and $\mathrm{Sr}$ are somewhat enriched over seawater, and range from 0.81 to $1.0 \mathrm{mmol} / \mathrm{kg}(\sim 12 \%)$ and 96.1 to $101 \mu \mathrm{mol} / \mathrm{kg}$ $(\sim 11 \%)$ (Table 1). 
Because $\mathrm{Cl}$ is the dominant anion in vent fluids, and charge balance constraints dictate that changes in $\mathrm{Cl}$ induce changes in dissolved cations, it is common practice to normalize elements to $\mathrm{Cl}$. Normalization to $\mathrm{Cl}$ allows for identification of enrichments or depletions in vent fluid species relative to the starting seawater composition. Vent fluid $\mathrm{Sr} / \mathrm{Cl}$ and $\mathrm{Br} / \mathrm{Cl}$ ratios closely match seawater ratios, in contrast with the higher ratios observed for other major species (Table 2). Dissolved metals are in high abundance relative to seawater, but endmember abundances of Fe (5.7 to $450 \mu \mathrm{mol} / \mathrm{kg})$ (Fig. 4A), Mn (8.4 to $16 \mu \mathrm{mol} / \mathrm{kg})$ (Fig. 4B), Zn (0.2 to $19 \mu \mathrm{mol} / \mathrm{kg}$ ) (Fig. 4C), and $\mathrm{Cu}$ (below detection to $222 \mu \mathrm{mol} / \mathrm{kg}$ ) (Fig. 4D) are low relative to higher-temperature vent fields on the MAR (DOUVILlE et al., 2002; JAMES et al., 1995). All vents at Von Damm are characterized by single endmember $\mathrm{Cl}, \mathrm{Na}, \mathrm{Ca}, \mathrm{K}, \mathrm{SiO}_{2}, \mathrm{Li}, \mathrm{Rb}$, and $\mathrm{Sr}$ abundances that were invariant in 2012 and 2013 within the range of measurement error (Table 1). These species all plot along conservative mixing lines (Figs. 2B, 3) indicating that one source fluid feeds the Von Damm field at depth. Endmember abundances are not calculated for the lowest-temperature Shrimp Hole fluid, as it contains a small fraction of hydrothermal fluid relative to seawater and, hence, extrapolation errors are large. Measured $\mathrm{pH}\left(25^{\circ} \mathrm{C}\right)$ ranged from 5.56 to 7.73 , with increasing $\mathrm{pH}$ coinciding with higher degrees of subsurface seawater mixing, as indicated by $\mathrm{Mg}$ content. The lowest $\mathrm{pH}$ value of 5.56 at the East Summit vent best represents the $\mathrm{pH}$ of the source fluid.

\subsection{Volatile aqueous species}

Von Damm vent fluids are highly enriched in aqueous $\mathrm{H}_{2}$, with a high-temperature 2012 East Summit endmember fluid composition of $18.2 \mathrm{mmol} / \mathrm{L} \mathrm{H}_{2}$ in 2012 , which, within error, is the same as the 2013 value of $18.4 \mathrm{mmol} / \mathrm{L}$ (Fig. 5A, Table 1). At the time of sampling, the $\mathrm{H}_{2}$ 
contents in these fluids represented the highest bare-rock $\mathrm{H}_{2}$ abundances of any vent fluid, worldwide, and are even higher than the previous world-record holder, the Rainbow hydrothermal field (13 to $16 \mathrm{mmol} / \mathrm{L} \mathrm{H}_{2}$ ) (CHARLOU et al., 2002; CHARLOU et al., 2010). In some lower temperature fluids (e.g. Old Man Tree), measured $\mathrm{H}_{2}$ is significantly depleted relative to the conservative mixing line between seawater and the zero-Mg endmember fluid (Fig. 5A). This non-conservative behavior results from processes occurring during mixing between an endmember fluid and seawater in the subsurface, prior venting at the seafloor. Because aqueous concentrations of non-conservative species are modified during mixing, calculation of zero-Mg endmembers has no meaning, and non-conservative elements and species in mixed fluids are considered in terms of measured abundances only.

Dissolved $\Sigma \mathrm{H}_{2} \mathrm{~S}$ abundances are moderately high, and the 2012 East Summit 3.24 $\mathrm{mmol} / \mathrm{L}$ endmember concentration is similar to those observed at Rainbow (1.2 to $1.4 \mathrm{mmol} / \mathrm{L}$ (CHARlou et al., 2010)) as well as at non-eruptive basalt-hosted hydrothermal fields on slow spreading ridges, such as Lucky Strike (1.4 to $4.6 \mathrm{mmol} / \mathrm{L}$ (CHARLOU et al., 2000; VON DAMM et al., 1998)) and TAG (2.9 to $3.4 \mathrm{mmol} / \mathrm{L}$ (ChARlou et al., 2010)) (Table 1). Mixed fluid $\mathrm{H}_{2} \mathrm{~S}$ concentrations behave conservatively in both 2012 and 2013 (Fig. 5B). Endmember $\mathrm{H}_{2} \mathrm{~S}$ values of 2.35 and $2.40 \mathrm{mmol} / \mathrm{L}$ in mixed fluids sampled in 2013 are similar to 2012 endmember values.

Von Damm East Summit 2012 fluids contain an endmember $\Sigma \mathrm{CO}_{2}$ abundance of 2.80 $\mathrm{mmol} / \mathrm{kg}$ that is slightly enriched relative to bottom seawater (Fig. 6A). Mixed fluids display non-conservative behavior in which $\Sigma \mathrm{CO}_{2}$ abundances are significantly depleted relative to the seawater-endmember conservative mixing line (CHAPTER 2 for discussion). Von Damm fluids are very enriched in aqueous $\mathrm{CH}_{4}$, and the high-temperature 2012 East Summit endmember composition of $2.81 \mathrm{mmol} / \mathrm{L} \mathrm{CH}_{4}$ in 2012 is similar to the 2013 endmember value of 3.17 
mmol/L (Fig. 6B). These $\mathrm{CH}_{4}$ contents are comparable to other ultramafic-influenced hydrothermal fields, such as Lost City (0.9 to $2.0 \mathrm{mmol} / \mathrm{kg}$ ) and Rainbow (2.5 mmol $/ \mathrm{kg}$ ) (ChARLOU et al., 2002; ProskUROWSKI et al., 2008). Endmember longer-chained hydrocarbon concentrations are consistent between years, as the 2013 Twin Peaks endmember values of 644 $\mathrm{nmol} / \mathrm{kg} \mathrm{C}_{2} \mathrm{H}_{6}, 56 \mathrm{nmol} / \mathrm{kg} \mathrm{C}_{3} \mathrm{H}_{8}, 4.3 \mathrm{nmol} / \mathrm{kg} \mathrm{n}-\mathrm{C}_{4} \mathrm{H}_{10}, 9.6 \mathrm{nmol} / \mathrm{kg} \mathrm{i}-\mathrm{C}_{4} \mathrm{H}_{10}$, and $21 \mathrm{nmol} / \mathrm{kg}$ $\mathrm{C}_{6} \mathrm{H}_{6}$ are typically within the range in endmember concentrations measured in 2012: 620 to 653 $\mathrm{nmol} / \mathrm{kg} \mathrm{C} \mathrm{H}_{6}, 54$ to $57 \mathrm{nmol} / \mathrm{kg} \mathrm{C} \mathrm{H}_{6}, 3.9$ to $8.0 \mathrm{nmol} / \mathrm{kg} \mathrm{n}-\mathrm{C}_{4} \mathrm{H}_{10}, 11$ to $18 \mathrm{nmol} / \mathrm{kg} \mathrm{i}-\mathrm{C}_{4} \mathrm{H}_{10}$, and 25 to $30 \mathrm{nmol} / \mathrm{kg} \mathrm{C}_{6} \mathrm{H}_{6}$ (Table 3). Von Damm vent fluid $\mathrm{C}_{6} \mathrm{H}_{6}$ abundances range from 21 to $30 \mathrm{nmol} / \mathrm{kg}$. Fluid $\mathrm{C}_{6} \mathrm{H}_{6}$ contents have not been previously quantified in unsedimented deep-sea vent fluids, and Von Damm $\mathrm{C}_{6} \mathrm{H}_{6}$ abundances are lower than endmember $\mathrm{C}_{6} \mathrm{H}_{6}$ abundances at the sediment-influenced Main Endeavour Field on the Juan de Fuca Ridge, which range from 1.4 to $3.7 \mu \mathrm{mol} / \mathrm{kg}$ (CRUSE and SEEWALD, 2010). Conservative behavior during subseafloor mixing is observed for $\mathrm{CH}_{4}, \mathrm{C}_{2} \mathrm{H}_{6}, \mathrm{C}_{3} \mathrm{H}_{6}, \mathrm{n}-\mathrm{C}_{4} \mathrm{H}_{10}, \mathrm{i}-\mathrm{C}_{4} \mathrm{H}_{10}$, and $\mathrm{C}_{6} \mathrm{H}_{6}$ in all vents sampled in 2012 and 2013 (Fig. 6B, 6C, 6D, 6E, 6F).

\subsection{Carbon, sulfur, and strontium stable isotopes}

The $\delta^{13} \mathrm{C}$ value of East Summit $2012 \Sigma \mathrm{CO}_{2}$ is $1.0 \%$, a value similar to that of bottom seawater at $0.9 \%$. Mixed fluid $\Sigma \mathrm{CO}_{2} \delta^{13} \mathrm{C}$ values are ${ }^{13} \mathrm{C}$-enriched relative to the endmember, with a maximum value of 3.79\% (CHAPTER 2). $\mathrm{CH}_{4}, \mathrm{C}_{2} \mathrm{H}_{6}$, and $\mathrm{C}_{3} \mathrm{H}_{8}$ measured on 2013 samples are within the ranges measured in 2012 , with $\mathrm{CH}_{4}$ values varying from $-15.8 \%$ o to $-15.0 \%, \mathrm{C}_{2} \mathrm{H}_{6}$ from - $13.2 \%$ to $-12.3 \%$, and $\mathrm{C}_{3} \mathrm{H}_{8}$ from $-11.6 \%$ to $-9.2 \%$ o $\left(\mathrm{C}_{3} \mathrm{H}_{8}\right)$ (CHAPTER 2). The $\delta^{13} \mathrm{C}$ values of $\mathrm{C}_{6} \mathrm{H}_{6}$ range from $-19.6 \%$ to $-17.7 \%$. The $\delta^{34} \mathrm{~S}$ values of dissolved $\mathrm{H}_{2} \mathrm{~S}$ ranged between $+9.9 \%$ to $+11.2 \%$, showing greater ${ }^{34} \mathrm{~S}$-enrichment than is commonly seen in high-temperature 
vent systems, where maximum $\delta^{34} \mathrm{~S}_{\mathrm{H} 2 \mathrm{~S}}$ values are $\sim+6 \%$ (SHANKS, 2001). Endmember ${ }^{87} \mathrm{Sr} /{ }^{86} \mathrm{Sr}$ isotopic composition ranged from 0.70382 to 0.70401 , and is within the known global range for hydrothermal fluids (AlBARÈDE et al., 1981; RAVIZZA et al., 2001). Considering analytical errors in the $\mathrm{Mg} / \mathrm{Sr}$ ratio, there is likely one $\mathrm{Sr}$ isotopic endmember for the entire Von Damm vent field, and it is best represented by the 0.70393 endmember value calculated from the East Summit fluid (Fig. 7).

\section{Discussion}

Vent fluid circulation within an oceanic core complex shares similarities with other convective deep-sea hydrothermal systems. The composition of a seafloor vent fluid reflects the cumulative influence of a variety of factors, including the initial bottom seawater composition, the composition of the rock through which the fluid circulates, the depth of circulation, and the nature of the heat source. These last two factors determine the pressure and temperature conditions of water-rock reaction and establish whether or not the fluid reaches the two-phase boundary (BISCHOFF and RoSENBAUER, 1985) (Fig. 8A), triggering phase separation. Seawater descends through permeable rock within the 'recharge' zone, first undergoing lower temperature chemical reactions. Extensive further reaction occurs during progressive heating with increasing depth, until the fluid attains its highest temperature in the 'reaction' zone. As seawater circulates through the hydrothermal system, its composition is modified by water-rock reaction. Because hot fluids are buoyant relative to cold seawater, they ascend through the 'discharge' zone toward the seafloor. In basalt-hosted hydrothermal systems, the integrated effect of hydrothermal circulation is the transformation of seawater into a $\mathrm{Mg}$ - and $\mathrm{SO}_{4}$-poor, slightly acidic, anoxic 
fluid that is enriched in alkalis, $\mathrm{Ca}, \mathrm{SiO}_{2}$, metals, $\mathrm{H}_{2} \mathrm{~S}$, and $\mathrm{CO}_{2}$, and vents at the seafloor at temperatures that are often as high as 350 to $400^{\circ} \mathrm{C}$.

Relatively high dissolved $\mathrm{CH}_{4}$ and $\mathrm{H}_{2}$ abundances distinguish Von Damm fluids from those emanating from basalt-hosted hydrothermal fields and indicate the influence of serpentinization of an olivine-rich protolith on fluid chemistry. Fluid $\mathrm{SiO}_{2}$ content is similar to what would be expected in a typical mid-ocean ridge hydrothermal fluid at $\sim 226^{\circ} \mathrm{C}$, however, and precludes an exclusively or dominantly peridotite-hosted system like that attributed to Lost City. The high $\mathrm{SiO}_{2}$ content requires that the Von Damm fluids must also have undergone reaction with olivine-rich gabbroic rocks along their subsurface circulation pathway.

\subsection{Water-rock reaction}

There is one calculated endmember composition for each conservative ionic species in

the Von Damm vents (e.g. not Fe, Mn, Cu, Zn), demonstrating that the entire $200 \mathrm{~m}^{2}$ sampled area is fed by a single endmember fluid (Table 1). All intermediate and low temperature venting is the result of a high-temperature fluid mixing with seawater (Fig. 2B). In many vent fluids, $\mathrm{Cl}$ variability is attributed to phase separation at elevated pressures and temperatures. To attain the measured temperatures, however, Von Damm fluids would have cooled by at least $150^{\circ} \mathrm{C}$ following phase separation (Fig. 8A). Although phase separation at higher temperatures and subsequent cooling cannot be precluded, there is no other evidence (e.g. high dissolved metal contents) that the source fluid was ever this hot.

Hydration of olivine and removal of water from circulating fluids into secondary minerals during serpentinization is another process that could result in elevated $\mathrm{Cl}$, particularly at low water/rock mass ratio (w/r) (ALLEN and SEYFRIED, 2004). Serpentinization can also remove Cl 
from the fluid via incorporation into secondary minerals, however. For example, serpentine, brucite, and magnetite can be produced during olivine hydrolysis, and brucite can then undergo alteration either to magnetite, serpentinite or iowaite, a magnesium hydroxide-ferric oxychloride that can contain up to $7 \mathrm{wt} \% \mathrm{Cl}$ (BACH et al., 2004; FRÜH-GREEN et al., 2004). Endmember $\mathrm{Br} / \mathrm{Cl}$ ratios near that of seawater (Table 2), however, indicate that $\mathrm{Br}$ and $\mathrm{Cl}$ were similarly affected during fluid formation, as would be expected from dehydration, and there were no substantive $\mathrm{Cl}$ losses relative to $\mathrm{Br}$. Therefore, the $\mathrm{Cl}$ and $\mathrm{Br}$ enrichments observed in Von Damm fluids likely reflect the loss of water due to hydrated mineral formation.

In serpentinizing hydrothermal systems, the ferrous $\mathrm{Fe}$ component of igneous silicate minerals is partially oxidized by water to form ferric Fe-bearing mineral phases, and water is reduced to $\mathrm{H}_{2}$ (MCCOLLom and SeEwald, 2007; KLein et al., 2013; MCCOLlOM and BACH, 2009). The high $\mathrm{H}_{2}$ content of venting fluids provides evidence for active serpentinization occurring during hydrothermal circulation at Von Damm. Fluid interaction with gabbroic substrate is likely on Mount Dent, and the most abundant exposed rock types in the area, olivine gabbro and troctolite, are rich in olivine ( 10 to 30 modal \% olivine) (HAYMAN et al., 2011; Stroup and FoX, 1981; White and Stroup, 1979). One example of a serpentization reaction is the hydrolysis of olivine to form magnetite, which is a likely alteration mineral in the circulation system underlying Von Damm:

$$
\begin{aligned}
& \mathrm{Mg}_{1.8} \mathrm{Fe}_{0.2} \mathrm{SiO}_{4}+1.37 \mathrm{H}_{2} \mathrm{O}=0.5 \mathrm{Mg}_{3} \mathrm{Si}_{2} \mathrm{O}_{5}(\mathrm{OH})_{4}+0.3 \mathrm{Mg}(\mathrm{OH})_{2}+0.067 \mathrm{Fe}_{3} \mathrm{O}_{4}+0.067 \mathrm{H}_{2} \\
& \text { Olivine Serpentine Brucite Magnetite }
\end{aligned}
$$


Ultramafic peridotite substrates are also a potential source of abundant olivine, however the Von Damm East Summit fluid endmember $\mathrm{SiO}_{2}$ composition of $7.56 \mathrm{mmol} / \mathrm{kg}$ would be a remarkably high concentration if it were derived from peridotite-hosted water-rock reaction alone (Fig. 4B). High $\mathrm{SiO}_{2}$ abundances in the Von Damm fluids indicate reaction with rock types containing higher $\mathrm{SiO}_{2}$ than periodotite, such as basalt or gabbro. Reaction path models and laboratory experiments support this observation, as they demonstrate that peridotite-seawater reaction will generate fluids containing much lower dissolved $\mathrm{SiO}_{2}$ then would be produced by basaltseawater at the same temperature (ALLEN and SEYFRIED, 2003; MCCOLLOM and BACH, 2009; WeTZEL and SHOCK, 2000).

In addition to troctolite, basalt outcrops are also observed at Von Damm (BALLARD et al., 1979; StROUP and Fox, 1981; F. Klein pers. comm.). This heterogeneity in surface outcrop lithologies precludes the identification of a single substrate undergoing reaction, and fluid chemistry suggests that subseafloor fluid-rock reaction with more than one type of substrate is possible. High $\mathrm{H}_{2}$ and $\mathrm{SiO}_{2}$ abundances at Von Damm require that fluids have reacted with olivine-rich and relatively $\mathrm{SiO}_{2}$ rich rocks. The observed fluid chemistry may therefore be derived from sequential reaction of peridotite and olivine-rich gabbros. Fluid-rock reaction with basalt encountered along fluid circulation pathways could have further increased dissolved $\mathrm{SiO}_{2}$ in the fluids.

The $\mathrm{pH}\left(25^{\circ} \mathrm{C}\right)$ of 5.56 in the highest temperature Von Damm fluid is more alkaline than is commonly observed at higher temperature vent fields and can be attributed to the relatively lower temperatures of reaction at Von Damm, consistent with what is predicted from both theoretical calculations and experimental work in both basalt-seawater and peridotite-seawater systems (JANECKY and SEYFRIED, 1986; SEYFRIED et al., 1991). All cations are enriched with 
respect to seawater at Von Damm, and with the exception of $\mathrm{Sr} / \mathrm{Cl}$, their ratios are higher than seawater, indicating that interaction with the substrate has added these elements to the fluid, even after the effect of dehydration is considered. Laboratory experiments and geochemical modeling have shown that $\mathrm{K}$ in solution behaves conservatively during reaction with peridotite, due to the low K contents of that rock type (JANECKY and SEYFRIED, 1986; SEYFRIED and DiBBLE, 1980; Wetzel and SHOCK, 2000). Consequently, the enrichment of this species provides further indication that Von Damm fluids have likely reacted with gabbroic composition lithologies along at least part of their circulation pathway.

The Rainbow hydrothermal field is a well-studied system where vent fluids are thought to be generated via fluid-rock reaction involving both gabbroic and ultramafic substrates. Although Rainbow emits higher temperature fluids $\left(\sim 365^{\circ} \mathrm{C}\right)$ that are lower more acidic and more metalrich than those observed at Von Damm, the moderate $\mathrm{SiO}_{2}$ and high $\mathrm{H}_{2}$ and $\mathrm{CH}_{4}$ contents of Rainbow fluids evoke similarities with Von Damm fluid chemistry. Experiments, field observations and in situ $\mathrm{pH}$ measurements coupled with phase equilibrium modeling support alteration of gabbroic intrusions to a mineral assemblage consisting of chlorite, magnetite, talc and tremolite as an important control on the chemical evolution of Rainbow vent fluids (ALLEN and SEYFrIED, 2003; SEYFRIED et al., 2011). Fluid-rock reaction at Von Damm is occurring under different physical and chemical conditions than Rainbow, however a similar lowertemperature mineral assemblage including magnetite, chlorite, and talc potentially buffers the Von Damm system. Experimental work and geochemical modeling are needed to further elucidate options for possible substrates in this system.

The relatively low dissolved $\mathrm{H}_{2} \mathrm{~S}$ abundance in the Von Damm East Summit 2012 endmember reflects the moderate temperatures of water-rock reaction at Von Damm. Sulfur 
isotope analysis of vent fluid $\mathrm{H}_{2} \mathrm{~S}$ shows low variability in $\delta^{34} \mathrm{~S}$ values $(+9.9 \%$ to $+11.2 \%$ ), and the small amount of variation does not correlate with sampled temperature, or with fluid $\mathrm{H}_{2} \mathrm{~S}$ or $\mathrm{H}_{2}$ content. The major contributors to $\mathrm{H}_{2} \mathrm{~S}$ in vent fluids at unsedimented MOR hydrothermal systems are basalt-derived sulfide (pyrite and pyrrhotite) of mantle origin, with an average $\delta^{34} \mathrm{~S}$ value of $+0.1 \pm 0.5 \%$ (SAKAI et al., 1984), and reduced seawater $\mathrm{SO}_{4}$, with a $\delta^{34} \mathrm{~S}$ value of $+21.0 \pm 0.2 \%$ o (REES et al., 1978). Gabbros recovered from drill cores show more variability in sulfide $\delta^{34} \mathrm{~S}$ values, but average values of $+0.5 \pm 2.4 \%$ in Hole $735 \mathrm{~B}$ gabbros in the southwest Indian Ocean $(\mathrm{n}=16)($ ALT and ANDERSON, 1991) are similar to mantle and basalt values. The low $\mathrm{H}_{2} \mathrm{~S}$ abundance and ${ }^{34} \mathrm{~S}$-enriched $\delta^{34} \mathrm{~S}_{\mathrm{H} 2 \mathrm{~S}}$ values at Von Damm suggest that seawater $\mathrm{SO}_{4}$ persisting into the reaction zone underwent reduction to $\mathrm{H}_{2} \mathrm{~S}$ via oxidation of gabbroic and/or basaltic sulfide (Shanks and SeYFried, 1987; WoOdrufF and SHANKs, 1988), and dissolution of rock-derived sulfide generated endmember fluid $\delta^{34} \mathrm{~S}$ values that reflect relatively equal contributions of seawater and mantle-derived sulfur that varied from 47 to 53\% (Table 1). At Von Damm, relatively low reaction temperatures and higher $\mathrm{pH}$ values limited the relative contribution of ${ }^{34} \mathrm{~S}$-depleted $\mathrm{H}_{2} \mathrm{~S}$ sourced from dissolution of host rock sulfides, which contributes a greater fraction of sulfur to fluid $\mathrm{H}_{2} \mathrm{~S}$ budgets in higher temperature MOR hydrothermal systems (SHANKS, 2001).

During shallow subsurface fluid-seawater mixing, fluid $\mathrm{H}_{2} \mathrm{~S}$ could be impacted by microbial $\mathrm{SO}_{4}$ reduction, or by isotope exchange with $\mathrm{SO}_{4}$ that is derived from subseafloor anhydrite deposits or entrained seawater $\mathrm{SO}_{4}$. Recent multiple-stable sulfur isotope studies have shown that biological processes, such as microbial sulfate reduction, involve multiple fractionation steps and incomplete transfer of sulfur-containing material, and therefore follow discernably different mass-dependent fractionation laws that result in non-zero product $\mathrm{H}_{2} \mathrm{~S} \Delta^{33} \mathrm{~S}$ 
values (FARQUHAR et al., 2003; JOHNSTON, 2011; ONO et al., 2006). Isotope exchange between $\mathrm{SO}_{4}$ and $\mathrm{H}_{2} \mathrm{~S}$ can also generate elevated $\mathrm{H}_{2} \mathrm{~S} \Delta{ }^{33} \mathrm{~S}$ values (ONO et al., 2007). Von Damm vent fluid $\mathrm{H}_{2} \mathrm{~S}$ is characterized by near-zero $\Delta^{33} \mathrm{~S}$ values, indicating normal mass-dependent fractionation. The conservative behavior of $\mathrm{Ca}, \mathrm{Sr}$, and $\mathrm{SO}_{4}$ in mixed fluids at Von Damm demonstrates negligible anhydrite formation during fluid upflow in mixing zones (e.g., Fig. 2A). These results demonstrate a dominance of abiotic reactions affecting the sulfur system at Von Damm. There is no discernable contribution of microbially-mediated $\mathrm{SO}_{4}$ reduction or isotope exchange with $\mathrm{SO}_{4}$ to Von Damm fluid $\mathrm{H}_{2} \mathrm{~S}$ budgets, similar to what is observed in black smokers worldwide (e.g. CHAPTER 5).

The effect of lower temperatures and less acidic $\mathrm{pH}$ is expressed in the low metal content of the endmember fluid, due to the temperature sensitivity of metal-rich sulfide solubility. Unlike other dissolved species, such as $\Sigma \mathrm{H}_{2} \mathrm{~S}$, which is highest in the hottest East Summit fluid $\left(226^{\circ} \mathrm{C}\right)(\mathrm{Fig} .5 \mathrm{~A}), \mathrm{Fe}, \mathrm{Cu}$, and $\mathrm{Zn}$ contents are highest in the adjacent but lower temperature West Summit fluid $\left(123^{\circ} \mathrm{C}\right)$ (Fig. 5B, 5C, 5D). Although most sites at Von Damm were sampled from a naturally occurring free-flowing orifice, significant excavation of the mound with the IGT snorkels was performed in order to reveal an orifice for fluid sampling at the West Summit site. Hence, although the high $\mathrm{Fe}, \mathrm{Cu}$, and $\mathrm{Zn}$ contents appear reproducibly high for the two West Summit fluid samples, particle entrainment into the samplers was likely.

When entrainment of metal-rich particles from the deposits surrounding a vent occurs, these particles are then included in the 'dregs' metals aliquots and appear as enrichments in the reconstituted fluid metal budgets. This effect is most pronounced in the West Summit fluid, but may affect several other low-temperature fluids to a lesser degree (e.g. Ravelin \#1). Indeed, for the West Summit fluid, the excess Fe and Cu contents are contributed by the 'dregs' fraction, 
whereas the 'fluid' and 'filter' fractions are not particularly enriched in these metals. An enrichment in the $\Sigma \mathrm{H}_{2} \mathrm{~S}$ content of the West Summit fluid would be expected if the venting fluid had been impacted by dissolution of pyrite $(\sim 300 \mu \mathrm{mol} / \mathrm{L}$ expected $)$ or pyrrhotite $(\sim 600 \mu \mathrm{mol} / \mathrm{L}$ expected). A $\sim 300 \mu \mathrm{mol} / \mathrm{L}$ drop in $\mathrm{H}_{2}$ would be expected from pyrite dissolution. Such enrichments would be within the analytical error of the $\Sigma \mathrm{H}_{2} \mathrm{~S}$ and $\mathrm{H}_{2}$ measurements, and are not discernable. It is most likely that the elevated metals reflect coring, which would not have any effect on fluid $\Sigma \mathrm{H}_{2} \mathrm{~S}$ and $\mathrm{H}_{2}$ contents.

\subsection{Sources of hydrocarbons to Von Damm fluids}

Many hydrothermal abiotic organic synthesis experiments have sought to test scenarios in which $\mathrm{H}_{2}$ generated by serpentinization results in the production of organic compounds via reduction of $\Sigma \mathrm{CO}_{2}$ supplied by circulating seawater or magmatic volatiles (e.g. HORITA AND Berndt, 1999; McCollom AND SeEWALD, 2003; Foustoukos AND SEYFried, 2004;

McCollom AND SEEwald, 2006). In Chapter 2, however, it was shown that the abundant $\mathrm{CH}_{4}$ and longer chain hydrocarbons in Von Damm vent fluids might instead reflect leaching of fluids from carbon- and $\mathrm{H}_{2}$-rich fluid inclusions hosted in plutonic rocks, in contrast with existing paradigms. Briefly, CHAPTER 2 findings showed that Von Damm endmember $\mathrm{\Sigma CO}_{2}$ abundances and stable isotope values are nearly identical to those of bottom seawater at the MCR (Table 3, Table 4). The observation that $\Sigma \mathrm{CO}_{2}$ has been conserved during circulation through the crust has profound implications for the origin of $\mathrm{CH}_{4}$ at Von Damm, since the endmember fluid has doubled its carbon content relative to seawater by the addition of $2.8 \mathrm{mmol} / \mathrm{kg} \mathrm{CH} \mathrm{CH}_{4} \mathrm{CH}_{4}$ formation from inorganic sources is not occurring during active circulation of these fluids. 
Previous studies have examined high-carbon, high- $\mathrm{H}_{2}$ fluid inclusions in olivine-rich plutonic rocks at the Southwest Indian Ridge, MARK area on the MAR, and the MCR (KELLEY, 1996; KelLeY et al., 2002; KeLLEY and FrUH-GREen, 2001). These studies postulate that olivine-hosted inclusions containing magmatic $\Sigma \mathrm{CO}_{2}$ and $\mathrm{H}_{2} \mathrm{O}$ volatiles were subject to serpentinization, via reactions such as equation (3), resulting in a build up of $\mathrm{H}_{2}$. At cooler temperatures, these inclusions can undergo respeciation via $\mathrm{CO}_{2}$ reduction to form volatile inclusions that are enriched in $\mathrm{CH}_{4}$, and perhaps higher hydrocarbons as well. If tapped by a circulating hydrothermal system, these carbon-rich inclusions could then contribute significant quantities of abiogenic hydrocarbons to volatile budgets at hydrothermal vents (KELLEY and FRÜH-GREEN, 1999).

In CHAPTER 2, it was estimated that a w/r ratio of 2 to 5 was needed to leach sufficient carbon from inclusions to supply the observed fluid $\mathrm{CH}_{4}$ contents at Von Damm. This study further expands on that model by determining an independent estimate of the $\mathrm{w} / \mathrm{r}$ ratio at Von Damm that is derived from inorganic species. As an additional test for the fluid inclusion model, this study also seeks to determine whether the observed hydrocarbons are at thermodynamic chemical equilibrium under high-carbon, high- $\mathrm{H}_{2}$ conditions that are geologically reasonable and represent realistic conditions for trapped fluid inclusions.

\subsubsection{Water-rock ratio estimates}

Sr isotopes do not significantly fractionate during precipitation or dissolution reactions

and can be used to estimate w/r mass ratios. At Von Damm, endmember ${ }^{87} \mathrm{Sr} /{ }^{86} \mathrm{Sr}$ values are consistent with a significant contribution of rock-derived Sr (Fig. 7). Mount Dent troctolite and olivine gabbro are not yet characterized for $\mathrm{Sr}$ abundance and isotopic composition, but similar 
lithologies recovered from the IODP site U1309D at the Atlantis Massif $\left(30^{\circ} \mathrm{N}\right.$ MAR) provide a framework to understand fluid-rock reaction at Von Damm, as this core consists of some of the least-altered gabbroic rocks sampled from a MOR (Drouin et al., 2009). Hole U1309D troctolites contain a bulk Sr content of $\sim 80 \mathrm{ppm}$ (range 40 to $120 \mathrm{ppm}$ ) and ${ }^{87} \mathrm{Sr} /{ }^{86} \mathrm{Sr}$ value of 0.7026 (CASEY, 1997; GODARD et al., 2009). Isotope mass balance between rock- and seawaterderived $\mathrm{Sr}\left({ }^{87} \mathrm{Sr} /{ }^{86} \mathrm{Sr}\right.$ ratio 0.70917$)$ indicates that Von Damm fluids are comprised of $\sim 20 \%$ seawater- and $\sim 80 \%$ rock-derived Sr. This finding is consistent with incomplete loss of sewaterderived Sr during anhydrite precipitation in the downwelling recharge zone, coupled with leaching of Sr from the rock. Anhydrite precipitation would lower dissolved Sr abundances but not impact isotopic composition, while leaching of rock which will replenish Sr abundances while lowering the fluid ${ }^{87} \mathrm{Sr} /{ }^{86} \mathrm{Sr}$ ratio. Despite relatively low temperatures and near-seawater absolute Sr abundances, Von Damm fluids show Sr isotopic evidence for leaching of rocks on par with what is seen in higher temperature $>350^{\circ} \mathrm{C}$ mid-ocean ridge fluids (ALBARÈDE et al., 1981; RAVIZZA et al., 2001).

A w/r ratio calculated from $\mathrm{Sr}$ isotopes reflects the cumulative effect of alteration of $\mathrm{Sr}$ rich phases during fluid circulation, but does not have any absolute physical meaning (BERNDT et al., 1988). An additional caveat at Von Damm is that dehydration of the circulating fluids likely increased the Sr concentration in solution without impacting the fluid isotopic signature. With this in mind, application of the simultaneous dissolution and precipitation model developed by BERNDT ET AL. (1988) permits calculation of a $\mathrm{w} / \mathrm{r}$ ratio that is parameterized by simultaneous release of rock-derived $\mathrm{Sr}$ and precipitation of $\mathrm{Sr}$ into secondary mineral phases (eqn. 11, 12, 13 in BERNDT ET AL., 1998). Allowing for variability in substrate Sr content, and possible rock hydration effects on fluid Sr content, the predicted w/r ratio for the Von Damm East Summit 
fluid is 2 to 6 (Fig. 9) which is in excellent agreement to the w/r ratio of 2 to 5 calculated in CHAPTER 2.

In hydrothermal fluids, $\mathrm{Li}$ and $\mathrm{Rb}$ are also useful tracers of $\mathrm{w} / \mathrm{r}$ ratio because they are considered mobile elements. Their abundance in solution is determined mainly by leaching of host rock, and to a lesser degree by formation of secondary minerals. Using average Li (5.0 ppm) and $\mathrm{Rb}(0.42 \mathrm{ppm})$ contents of U1309D troctolites $(\mathrm{n}=11)(\mathrm{CASEY}, 1997$; GODARD et al., 2009) yields a calculated $\mathrm{w} / \mathrm{r}$ ratio of 0.7 to 0.8 for $\mathrm{Li}$, and 0.2 to 0.4 for $\mathrm{Rb}$. In both cases, the higher end of the range reflects a correction for a potential minor fluid dehydration effect. The relatively higher w/r ratio calculated for Li likely reflects non-quantitative leaching of Li, which is more readily incorporated in secondary minerals than $\mathrm{Rb}$ in laboratory experiments (BERGER et al., 1988; SEYFRIED et al., 1984). Fluid/rock ratios calculated using Sr isotopes typically yield values that are an order of magnitude higher than those calculated for alkali elements (BERNDT et al., 1988), as is also seen here. This contrast in $\mathrm{w} / \mathrm{r}$ ratios arises due to differences in the location in the rock of these elements. The alkali metals are relatively incompatible with mineral sites, thus they are likely concentrated in more unstable phases and glasses. The alkali-rich phases are therefore easily leached and only minimally impacted by incorporation into secondary minerals. In contrast, $\mathrm{Sr}$ is concentrated in plagioclase minerals, which are distributed relatively more homogenously through the basalt. The alkali metal $\mathrm{w} / \mathrm{r}$ ratios therefore provide a sense for the amount of alkali-containing minerals altered, while w/r ratios derived from $\mathrm{Sr}$ give a sense for the degree of aleration of Sr-contining minerals and recrystallization to form secondary minerals. The inorganic $\mathrm{w} / \mathrm{r}$ ratios predicted from $\mathrm{Sr}$ isotopes and $\mathrm{Li}$ and $\mathrm{Rb}$ mass balance align well with the leachable carbon-based $\mathrm{w} / \mathrm{r}$ ratio of 2 to 5 that was postulated in CHAPTER 2, therefore it is 
feasible that $\mathrm{CH}_{4}$ (and other hydrocarbons) at Von Damm could be derived from leaching of Mid-Cayman Rise gabbros.

\subsubsection{Hydrocarbon chemical equilibrium model}

A thermodynamic equilibrium carbon speciation model was constructed to test the feasibility of a plutonic fluid inclusion source of $\mathrm{CH}_{4}, \mathrm{C}_{2} \mathrm{H}_{6}, \mathrm{C}_{3} \mathrm{H}_{8}, \mathrm{n}-\mathrm{C}_{4} \mathrm{H}_{10}$, and $\mathrm{C}_{6} \mathrm{H}_{6}$ to the endmember Von Damm fluids. The model is designed to demonstrate whether or not the observed distribution of hydrocarbon species reflects an equilibrium condition within a fluid inclusion that is geologically reasonable, in terms of temperature, pressure, redox state, and total carbon. Preliminary studies indicate that Mount Dent fluid inclusions are gas phase and are rich in $\mathrm{H}_{2}$ and $\mathrm{CH}_{4}$ (F. Klein, pers. comm.). The degree of reduction of $\Sigma \mathrm{CO}_{2}$ to hydrocarbons is governed by the reducing power of the fluid. $\mathrm{H}_{2}$ would act as the major reducing agent in a fluid inclusion, thus the redox state in the model is controlled by the fugacity of $\mathrm{H}_{2}$, which was set to a range of conditions that are consistent with the pyrite-pyrrhotite-magnetite (PPM) and quartzfayalite-magnetite (QFM) redox buffers in a gas phase environment between $200^{\circ} \mathrm{C}$ to $380^{\circ} \mathrm{C}$ (Fig. 10). Although the specific redox state of olivine hosted fluid inclusions is unknown, conditions intermediate between PPM and FMQ are often invoked in conceptual models (KeLley, 1996). The model was run at 500 bars pressure, as this is a reasonable internal pressure for a volatile-rich fluid inclusion (KLÜGEL and KLEIN, 2006; VANKO, 1988). The model is designed to calculate the speciation of carbon as governed by the following reactions:

$$
\begin{aligned}
& \mathrm{CO}_{2(\mathrm{~g})}+4 \mathrm{H}_{2(\mathrm{~g})}=\mathrm{CH}_{4(\mathrm{~g})}+2 \mathrm{H}_{2} \mathrm{O}_{(\mathrm{g})} \\
& 2 \mathrm{CH}_{4(\mathrm{~g})}=\mathrm{C}_{2} \mathrm{H}_{6(\mathrm{~g})}+\mathrm{H}_{2(\mathrm{~g})}
\end{aligned}
$$




$$
\begin{aligned}
& 3 \mathrm{CH}_{4(\mathrm{~g})}=\mathrm{C}_{3} \mathrm{H}_{8(\mathrm{~g})}+2 \mathrm{H}_{2(\mathrm{~g})} \\
& 4 \mathrm{CH}_{4_{(\mathrm{g})}}=\mathrm{C}_{4} \mathrm{H}_{10_{(\mathrm{g})}}+3 \mathrm{H}_{2(\mathrm{~g})} \\
& 5 \mathrm{CH}_{4_{(\mathrm{g})}}=\mathrm{C}_{5} \mathrm{H}_{12_{(\mathrm{g})}}+4 \mathrm{H}_{2(\mathrm{~g})} \\
& 6 \mathrm{CH}_{4_{(\mathrm{g})}}=\mathrm{C}_{6} \mathrm{H}_{6(\mathrm{~g})}+9 \mathrm{H}_{2(\mathrm{~g})}
\end{aligned}
$$

Although the observed abundances of $\mathrm{CH}_{4}, \mathrm{C}_{2} \mathrm{H}_{6}, \mathrm{C}_{3} \mathrm{H}_{8}, \mathrm{n}-\mathrm{C}_{4} \mathrm{H}_{10}$, and $\mathrm{C}_{6} \mathrm{H}_{6}$ in Von Damm fluids have potentially undergone dilution by mixing into circulating fluids that were hydrocarbonpoor, if a single hydrocarbon source is assumed, then observed ratios should match the ratios set during formation conditions. Hydrocarbon ratios are sensitive to total carbon in the system, due to the power term on $\mathrm{CH}_{4}$ in the equilibrium constant denominators, e.g. for equation (5):

$$
K_{e q(5)}=\frac{\left(f \mathrm{C}_{2} \mathrm{H}_{6}\right)\left(f \mathrm{H}_{2}\right)}{\left(f \mathrm{CH}_{4}\right)^{2}}
$$

In all model runs, a total carbon equivalent to 10 mol carbon per $\mathrm{L}$ of fluid inclusion volume was used. The fugacity of $\mathrm{H}_{2} \mathrm{O}\left(f \mathrm{H}_{2} \mathrm{O}\right)$ was set to 1 bar. Order of magnitude variation in $f \mathrm{H}_{2} \mathrm{O}$ did not substantively affect model results, because it only directly influences equilibrium between $\mathrm{CO}_{2}$ and $\mathrm{CH}_{4}$, and is only important when $\mathrm{CO}_{2}$ is the stable form of carbon (i.e. $\mathrm{T}>$ $400^{\circ} \mathrm{C}$ ). At the conditions modeled, $\mathrm{CH}_{4}$ and other hydrocarbons are highly favored over $\mathrm{CO}_{2}$ (Fig. 11).

The observed fluid $\mathrm{CH}_{4} / \mathrm{C}_{2} \mathrm{H}_{6}, \mathrm{CH}_{4} / \mathrm{C}_{3} \mathrm{H}_{8}, \mathrm{CH}_{4} / \mathrm{n}-\mathrm{C}_{4} \mathrm{H}_{10}$ and $\mathrm{CH}_{4} / \mathrm{C}_{6} \mathrm{H}_{6}$ ratios are not at chemical equilibrium at the measured $\mathrm{H}_{2}$ and seafloor temperature conditions. At a modeled $f \mathrm{H}_{2}$ of 0.2 bar, however, the observed fluid $\mathrm{CH}_{4} / \mathrm{C}_{2} \mathrm{H}_{6}, \mathrm{CH}_{4} / \mathrm{C}_{3} \mathrm{H}_{8}, \mathrm{CH}_{4} / \mathrm{n}-\mathrm{C}_{4} \mathrm{H}_{10}$ and $\mathrm{CH}_{4} / \mathrm{C}_{6} \mathrm{H}_{6}$ ratios match the model results at temperatures of $260^{\circ} \mathrm{C}, 330^{\circ} \mathrm{C}, 360^{\circ} \mathrm{C}$ and $360^{\circ} \mathrm{C}$, respectively (Fig. $12 \mathrm{~A}, 12 \mathrm{~B}, 12 \mathrm{C}$, and 12D). The temperature range predicted from chemical equilibrium for these 
species coincides well with the $330^{\circ} \mathrm{C}$ to $370^{\circ} \mathrm{C}$ range predicted from observed $\mathrm{CH}_{4}-\mathrm{C}_{2} \mathrm{H}_{6}$ and $\mathrm{CH}_{4}-\mathrm{C}_{3} \mathrm{H}_{8} \delta^{13} \mathrm{C}$ isotope fractionations (CHAPTER 2). As discussed in CHAPTER 2, the relatively ${ }^{13} \mathrm{C}$-enriched $\delta^{13} \mathrm{C}$ values observed for Von Damm $\mathrm{CH}_{4}, \mathrm{C}_{2} \mathrm{H}_{6}$, and $\mathrm{C}_{3} \mathrm{H}_{8}$ indicate an abiotic origin, rather than microbial or thermogenic sources. Similarly, $\mathrm{C}_{6} \mathrm{H}_{6}$ values at Von Damm that range from $-19.6 \%$ to $-17.7 \%$ are ${ }^{13} \mathrm{C}$-enriched relative to the $-22.5 \%$ to $-22.3 \%$ values measured at the sediment-influenced Main Endeavour Field (CRUSE and SEewALD, 2010), and support an abiotic origin of $\mathrm{C}_{6} \mathrm{H}_{6}$ at Von Damm. Model runs in this temperature range predict formation of only 6 to $61 \mathrm{pmol} / \mathrm{kg} \mathrm{n}-\mathrm{C}_{5} \mathrm{H}_{12}$ in the Von Damm fluids, hence it is not surprising that $\mathrm{n}-\mathrm{C}_{5} \mathrm{H}_{12}$ was below detection in the measured samples.

The equilibrium model only has significance if the entire hydrocarbon distribution can be explained. Model results for $\mathrm{CH}_{4} / \mathrm{C}_{2} \mathrm{H}_{6}$ do not match those for the other species, however. The model vs. observed temperature match of $260^{\circ} \mathrm{C}$ is $70^{\circ} \mathrm{C}$ to $100^{\circ} \mathrm{C}$ cooler than both the chemical equilibrium temperature range predicted from the higher hydrocarbons $\left(330^{\circ} \mathrm{C}\right.$ to $\left.370^{\circ} \mathrm{C}\right)$ and the inferred temperature of $\mathrm{CH}_{4}-\mathrm{C}_{2} \mathrm{H}_{6}$ equilibrium isotope fractionation $\left(370^{\circ} \mathrm{C}\right)$. At temperatures $>260^{\circ} \mathrm{C}$, the model predicts excess $\mathrm{C}_{2} \mathrm{H}_{6}$ relative to $\mathrm{CH}_{4}$ when compared to the observed $\mathrm{CH}_{4} / \mathrm{C}_{2} \mathrm{H}_{6}$.

These findings are overall consistent with a scenario in which $\mathrm{CH}_{4}$ and n-alkanes form abiotically within a high- $\mathrm{H}_{2}$, carbon-rich olivine-hosted fluid inclusion at temperatures $\sim 350^{\circ} \mathrm{C}$, and are subsequently liberated and transported to the seafloor during hydrothermal alteration of subeafloor rocks at the Mount Dent oceanic core complex. However, these model results suggest that Von Damm fluid hydrocarbon distributions do not reflect equilibrium at a single set of conditions. It is possible that the higher hydrocarbons were formed at different temperature regimes. 


\subsection{Origin of the Von Damm hydrothermal mound}

Initial studies of the Von Damm hydrothermal field mound have identified the presence of talc, intergrown with lesser quartz, in mineral structures associated with venting orifices. This talc could be derived either from primary hydrothermal precipitation, or from alteration and serpentinization of gabbroic or ultramafic rock (KLEIN et al., 2013). Textural relationships of talc and quartz in thin section petrography suggest that this deposit may form via precipitation from Von Damm vent fluids (Fig. 13A, 13B, 13C, 13D) (F. Klein and M.K. Tivey, pers. comm.). Trace amounts of pyrite and pyrrhotite were observed in the deposits sampled from higher temperature fluid flow regimes at the summit of the main mound, but not in the lower temperature regime mineral samples collected from the flanks where the mound is comprised of talc and quartz only. Field observations of a mound that is circular in plan-view, with $45^{\circ}$ sloping sides (Fig. 1), are also consistent with chemical precipitation around a vertical upflow pipe, rather than in situ rock alteration.

To further test whether the mound may have formed by mineral precipitation from Von Damm vent fluids, thermodynamic reaction path modeling for a high-temperature hydrothermal fluid mixing with seawater was conducted using the computer code EQ3/6, version 8.0 (WOLERY, 1992; WOLERY and DAVELER, 1992) with a 350 bar thermodynamic database assembled with SUPCRT92 (JOHNSON et al., 1992). Two model scenarios were conducted to assess field observations. In the first model, all mineral precipitation was supressed. Mineral saturation states were assessed in this model by incrementally reacting $1 \mathrm{~kg}$ of $226^{\circ} \mathrm{C}$ hydrothermal fluid with an East Summit endmember composition with $1 \mathrm{~kg}$ of $2^{\circ} \mathrm{C}$ seawater, and examining the saturation state of minerals in the resultant $115^{\circ} \mathrm{C}$ fluid. In the second model, 
fluids of the same composition were mixed under the same conditions, but mineral precipitation was allowed at each incremental mixing step. After each increment of seawater is added, an equilibrium composition of the fluid and mineral was calculated at the new temperature by minimizing Gibbs free energy. Minerals that form were removed from the chemical system before the next increment of seawater was added (i.e., no back-reaction was allowed). For both models, activity coefficients of dissolved inorganic species were calculated with the hard core diameter B-dot equation and the B-dot and Debye-Hückel parameter (WOLERY and JOVECOLON, 2004). Activity coefficients were assumed neutral for neutral species, except for nonpolar gaseous species, which were given the activity coefficients for $\mathrm{CO}_{2}$ (DRUMMOND, 1981). Charge balancing was performed on Na. Solid solutions used in the second reaction path model were talc (talc, minnesotaite) and chlorite (clinochlore, daphnite). Metastable equilibria for minerals were accounted for via suppression of antigorite, serpentine, graphite, dolomite, muscovite, amphibolite, aragonite, calcite, aragonite, tremolite, magnesite, diopside, biotite, muscovite, paragonite, phlogopite, microcline, plagioclase, prehnite, and gibbsite. Although thermodynamic equilibria predict the formation of these minerals, kinetic barriers would prevent their formation on the short timescales of mixing in the natural system.

Due to kinetic limitations that prevent equilibrium reduction of $\mathrm{CO}_{2}$, as demonstrated in Chapter 2 and in other studies (McCollom and SeEwald, 2001; SeEwald et al., 2006), metastable equilibria for carbon species were accounted for by suppressing $\mathrm{CH}_{4}, \mathrm{CH}_{3} \mathrm{OH}$, and acetate species formation; formate species were allowed to form in accordance with observations of equilibrium abiotic formate generation in CHAPTER 2 and laboratory experiments (SEEWALD et al., 2006). Similarly, re-equilibration of $\mathrm{SO}_{4}, \mathrm{H}_{2} \mathrm{~S}, \mathrm{H}_{2}$, and intermediate oxidation state sulfur 
species was suppressed due to slow kinetics that have been shown in past studies (Онмото and LASAGA, 1982).

In the first model, in which mineral precipitation was suppressed, all dissolved inorganic species behave conservatively (Fig 14A). Dissolved $\Sigma \mathrm{CO}_{2}$ also behaves conservatively, while $\mathrm{H}_{2}$ drops rapidly during intial mixing, and $\Sigma \mathrm{H}_{2} \mathrm{~S}$ shifts slightly during mixing (Fig 14B). Supersaturated minerals include talc, quartz, pyrite, and pyrrhotite. Chalcedony, an amorphous $\mathrm{SiO}_{2}$ phase, is also supersaturated. These results demonstrate a thermodynamic drive to form the mineral assemblage observed at Von Damm during mixing between the endmember fluid and seawater. Vent fluid $\mathrm{Mg}$ and $\mathrm{SiO}_{2}$ contents were observed to exhibit conservative behavior at Von Damm, therefore this first model is most representative of the real system.

It is possible, however, that small quantities of minerals do precipitate during fluid seawater mixing at Von Damm. The second model illustrates a scenario in which minerals are allowed to precipitate at equilibrium. During initial mixing with cold seawater, relatively large abundances of quartz are predicted to form, as well as talc and small amounts of pyrrhotite (Fig. 15A). The solid solution is dominated by talc formation (Mg-rich phase, $>0.9995$ mass fraction) and only trace amounts of minnesotaite (Fe-rich phase, $<0.0005$ mass fraction) are predicted to form at higher temperatures when more dissolved $\mathrm{Fe}$ is available (Fig. 15B). Reaction path profiles for individual species illustrate the effects of mineral precipitation and changing temperature during mixing. For example, while pyrrhotite is forming, $\mathrm{pH}$ (in situ) drops slightly, while $\mathrm{H}_{2}$ does not drop as much as may be expected for dilution (Fig. 15C), due to generation of $\mathrm{H}_{2}$ and acidity via the reaction:

$$
\mathrm{Fe}^{2+}+\mathrm{H}_{2} \mathrm{~S}_{(a q)}=\mathrm{FeS}_{(s)}+2 \mathrm{H}^{+}
$$


With continued mixing, which brings in abundant $\mathrm{Mg}$ from seawater (Fig. 15B), talc becomes by far the dominant precipitate over quartz. Trace amounts of chlorite solid solution are predicted to form (Fig. 14A), which is dominated by clinochlore (Mg-rich phase, $>0.84$ mass fraction) over daphnite (Fe-rich phase, $<0.16$ mass fraction) and removes some Al from solution (Fig. 15B). Similar to predictions for relative proportions of talc solid solution phases, the relative fractions of daphnite drop with decreasing Fe and greater mixing extent. Increased mixing results in dropping fluid $\mathrm{H}_{2}$ contents (Fig. $15 \mathrm{C}$ ), and around $200^{\circ} \mathrm{C}$ pyrrhotite formation is predicted to end, replaced by trace amounts of pyrite that are expected to form from $200^{\circ} \mathrm{C}$ to $115^{\circ} \mathrm{C}$. The mixing model concludes when equal parts hydrothermal fluid have mixed with seawater, at $115^{\circ} \mathrm{C}$ and an in situ $\mathrm{pH}$ of $\sim 6$, which matches well with the temperature $\left(115^{\circ} \mathrm{C}\right)$ and $\mathrm{pH}(5.89$, $\left.25^{\circ} \mathrm{C} 1 \mathrm{~atm}\right)$ measured at the Old Man Tree mixed fluid vent. The real composition of Old Man Tree fluids does not match this modelled composition, as $\mathrm{SiO}_{2}$ and $\mathrm{Mg}$ behave conservatively, and there is no evidence for any loss of $\mathrm{SiO}_{2}$ and $\mathrm{Mg}$ to form talc or quartz. From a thermodynamic perspective, the first model is a more accurate representation of the Von Damm system, while the second model demonstrates where the system wants to be. These mixing model results demonstrate that Von Damm fluids are supersaturated with the mineral assemblage associated with venting, including talc, quartz, chalcedony, pyrite, and pyrrhotite.

\section{SUMMARY}

At the recently discovered Von Damm deep-sea hydrothermal vent field, the inorganic geochemistry of circulating fluids is indicative of moderate temperature $\left(<250^{\circ} \mathrm{C}\right)$ sequential peridotite-gabbro fluid/rock reaction. Serpentinization of this olivine-rich protolith generated high- $\mathrm{H}_{2}$ fluids that contain dissolved $\mathrm{CH}_{4}, \mathrm{C}_{2} \mathrm{H}_{6}, \mathrm{C}_{3} \mathrm{H}_{8}, \mathrm{n}-\mathrm{C}_{4} \mathrm{H}_{10}$, and $\mathrm{i}-\mathrm{C}_{4} \mathrm{H}_{10}$ with abundances 
and isotope signatures similar to those observed at other ultramafic hosted systems. Abundant $\mathrm{C}_{6} \mathrm{H}_{6}$ was also detected in the fluids. Inorganic $\mathrm{w} / \mathrm{r}$ ratio considerations reveal values in the range of 0.2 to 0.8 and 2 to 6 , based on fluid $\mathrm{Li}$ and $\mathrm{Rb}$ abundances and $\mathrm{Sr}$ abundance and isotopes, respectively, that are consistent with the $\mathrm{w} / \mathrm{r}$ ratios of 2 to 5 predicted from fluid hydrocarbon and gabbroic rock bulk carbon contents at the MCR in CHAPTER 2. These results therefore support plutonic hosted, high-carbon, high- $\mathrm{H}_{2}$, gas inclusions as the source of the abundant hydrocarbons in Von Damm fluids. A gas inclusion hydrocarbon source was also tested by chemical equilibrium modeling that sought to match observed $\mathrm{CH}_{4} / \mathrm{C}_{2+}$ ratios at conditions that reflect the physical and chemical conditions expected for a fluid inclusion environment. These results indicate that the observed $\mathrm{CH}_{4} / \mathrm{C}_{2+}$ ratios do not reflect equilibrium at one temperature, however their formation at different temperatures remains possible. Geochemical modeling indicates that Von Damm fluids are supersaturated with minerals associated with venting, including talc, quartz, chalcedony, pyrite, and pyrrhotite. 


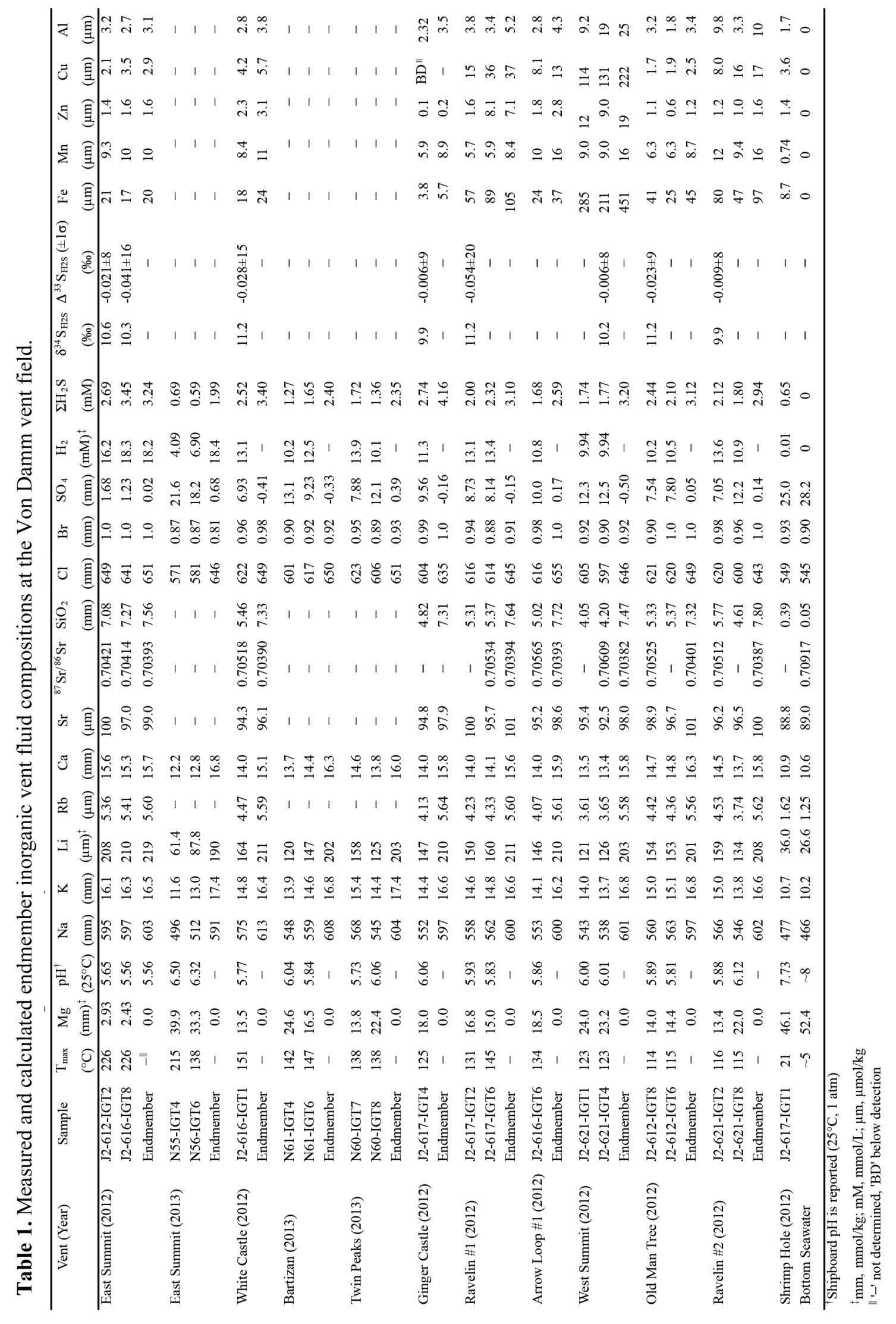


Table 2. Elemental ratios calculated from endmember fluid compositions at the Von Damm vent field.

\begin{tabular}{|c|c|c|c|c|c|c|c|c|c|c|c|c|c|}
\hline Vent (Year) & $\begin{array}{l}\mathrm{T}_{\max } \\
\left({ }^{\circ} \mathrm{C}\right)\end{array}$ & $\begin{array}{l}\mathrm{Mg}_{\min } \\
(\mathrm{mm})\end{array}$ & $\mathrm{Na} / \mathrm{Cl}$ & $\mathrm{K} / \mathrm{Cl}$ & $\mathrm{Ca} / \mathrm{Cl}$ & $\begin{array}{l}\mathrm{Sr} / \mathrm{Cl} \\
\left(\times 10^{-3}\right)\end{array}$ & $\begin{array}{l}\mathrm{Li} / \mathrm{Cl} \\
\left(\times 10^{-3}\right)\end{array}$ & $\begin{array}{l}\mathrm{Rb} / \mathrm{Cl} \\
\left(\times 10^{-3}\right)\end{array}$ & $\begin{array}{l}\mathrm{Br} / \mathrm{Cl} \\
\left(\times 10^{3}\right)\end{array}$ & $\begin{array}{l}\mathrm{Fe} / \mathrm{Cl} \\
\left(\times 10^{-3}\right)\end{array}$ & $\begin{array}{l}\mathrm{Mn} / \mathrm{Cl} \\
\left(\times 10^{-3}\right)\end{array}$ & $\mathrm{Fe} / \mathrm{Mn}$ & $\mathrm{Sr} / \mathrm{Ca}$ \\
\hline East Summit (2012) & 226 & 2.43 & 0.93 & 0.025 & 0.024 & 0.15 & 0.34 & 0.0086 & 1.6 & 0.030 & 0.016 & 1.9 & 6.3 \\
\hline East Summit (2013) & 215 & 33.3 & 0.91 & 0.027 & 0.026 & $-\|$ & - & - & - & - & - & - & - \\
\hline White Castle (2012) & 151 & 13.5 & 0.94 & 0.025 & 0.023 & 0.15 & 0.33 & 0.0086 & 1.5 & 0.038 & 0.017 & 2.2 & 6.4 \\
\hline Bartizan (2013) & 147 & 16.5 & 0.94 & 0.026 & 0.025 & - & - & - & - & - & - & - & - \\
\hline Twin Peaks (2013) & 138 & 13.8 & 0.93 & 0.027 & 0.025 & - & - & - & - & - & - & - & - \\
\hline Ginger Castle (2012) & 125 & 18.0 & 0.94 & 0.026 & 0.025 & 0.15 & 0.33 & 0.0089 & 1.6 & 0.009 & 0.014 & 0.64 & 6.2 \\
\hline Ravelin \#1 (2012) & 145 & 15.0 & 0.93 & 0.026 & 0.024 & 0.16 & 0.33 & 0.0087 & 1.4 & 0.16 & 0.013 & 13 & 6.5 \\
\hline Arrow Loop \#1 (2012) & 134 & 18.5 & 0.92 & 0.025 & 0.024 & 0.15 & 0.32 & 0.0086 & 1.6 & 0.057 & 0.024 & 2.4 & 6.2 \\
\hline West Summit (2012) & 123 & 23.2 & 0.93 & 0.026 & 0.024 & 0.15 & 0.31 & 0.0086 & 1.4 & 0.70 & 0.025 & 27 & 6.2 \\
\hline Old Man Tree (2012) & 115 & 14.0 & 0.92 & 0.026 & 0.025 & 0.16 & 0.31 & 0.0086 & 1.5 & 0.069 & 0.013 & 5.2 & 6.2 \\
\hline Ravelin \#2 (2012) & 116 & 13.4 & 0.94 & 0.026 & 0.025 & 0.16 & 0.32 & 0.0087 & 1.6 & 0.15 & 0.025 & 6.0 & 6.3 \\
\hline Bottom Seawater & $\sim 5$ & 52.4 & 0.85 & 0.019 & 0.019 & 0.16 & 0.049 & 0.0023 & 1.6 & $<0.00001$ & $<0.00001$ & - & 8.4 \\
\hline
\end{tabular}

"I.' not determined. 
Table 3. Measured and calculated carbon species abundances in vent fluids at the Von Damm vent field.

\begin{tabular}{|c|c|c|c|c|c|c|c|c|}
\hline Vent (Year) & Sample & $\begin{array}{l}\mathrm{CO}_{2} \\
(\mathrm{~mm})\end{array}$ & $\begin{array}{l}\mathrm{CH}_{4} \\
(\mathrm{mM})\end{array}$ & $\begin{array}{l}\mathrm{C}_{2} \mathrm{H}_{6} \\
(\mathrm{~nm})\end{array}$ & $\begin{array}{l}\mathrm{C}_{3} \mathrm{H}_{6} \\
(\mathrm{~nm})\end{array}$ & $\begin{array}{c}\mathrm{n}-\mathrm{C}_{4} \mathrm{H}_{10} \\
(\mathrm{~nm})\end{array}$ & $\begin{array}{c}\mathrm{i}-\mathrm{C}_{4} \mathrm{H}_{10} \\
(\mathrm{~nm})\end{array}$ & $\begin{array}{l}\mathrm{C}_{6} \mathrm{H}_{6} \\
(\mathrm{~nm})\end{array}$ \\
\hline \multirow[t]{3}{*}{ East Summit (2012) } & J2-612-IGT2 & 2.79 & 2.62 & 603 & 52 & 4.3 & 12 & 25 \\
\hline & J2-616-IGT8 & 2.75 & 2.72 & - & - & - & - & - \\
\hline & Endmember & 2.80 & 2.81 & 639 & 56 & 4.6 & 12 & 26 \\
\hline \multirow[t]{3}{*}{ East Summit (2013) } & N55-IGT4 & $-\|$ & 0.76 & - & - & - & - & - \\
\hline & N56-IGT6 & - & 1.16 & - & - & - & - & - \\
\hline & Endmember & - & 3.17 & - & - & - & - & - \\
\hline \multirow[t]{2}{*}{ White Castle (2012) } & J2-616-IGT1 & 2.51 & 2.08 & 485 & 41 & 2.9 & 10 & 20 \\
\hline & Endmember & - & 2.80 & 653 & 55 & 4.0 & 14 & 27 \\
\hline \multirow[t]{3}{*}{ Bartizan (2013) } & N61-IGT4 & - & 1.68 & - & - & - & - & - \\
\hline & N61-IGT6 & - & 2.07 & - & - & - & - & - \\
\hline & Endmember & - & 3.07 & - & - & - & - & - \\
\hline \multirow[t]{3}{*}{ Twin Peaks (2013) } & N60-IGT7 & - & 2.25 & 475 & 41 & 3.0 & 7.3 & 16 \\
\hline & N60-IGT8 & - & 1.65 & 368 & 33 & 2.7 & 5.2 & 12 \\
\hline & Endmember & - & 2.99 & 644 & 56 & 4.3 & 9.6 & 21 \\
\hline \multirow[t]{2}{*}{ Ginger Castle (2012) } & J2-617-IGT4 & 2.35 & 1.88 & - & - & - & - & - \\
\hline & Endmember & - & 2.95 & - & - & - & - & - \\
\hline \multirow[t]{3}{*}{ Ravelin \#1 (2012) } & J2-617-IGT2 & 2.40 & 1.96 & 431 & 38 & 3.2 & 7.4 & 18 \\
\hline & J2-617-IGT6 & 2.52 & 2.02 & - & - & - & - & - \\
\hline & Endmember & - & 2.86 & 634 & 56 & 4.8 & 11 & 26 \\
\hline \multirow[t]{2}{*}{ Arrow Loop \#1 (2012) } & J2-616-IGT6 & 2.27 & 1.74 & 417 & 36 & 10 & 9.1 & 14 \\
\hline & Endmember & - & 2.81 & 637 & 56 & 8.0 & 12 & 25 \\
\hline \multirow[t]{3}{*}{ West Summit (2012) } & J2-621-IGT1 & 2.08 & 1.64 & 359 & 30 & 2.2 & 6.9 & 13 \\
\hline & J2-621-IGT4 & 2.07 & 1.67 & 335 & 29 & 2.1 & 5.3 & 14 \\
\hline & Endmember & - & 3.01 & 630 & 54 & 3.9 & 11 & 25 \\
\hline \multirow[t]{3}{*}{ Old Man Tree (2012) } & J2-612-IGT8 & 2.03 & 1.92 & 455 & 40 & 4.6 & 13 & 18 \\
\hline & J2-612-IGT6 & 1.80 & 1.97 & - & - & - & - & - \\
\hline & Endmember & - & 2.67 & 620 & 55 & 6.2 & 18 & 24 \\
\hline \multirow[t]{3}{*}{ Ravelin \#2 (2012) } & J2-621-IGT2 & 1.98 & 2.10 & 475 & 40 & 3.0 & 8.0 & 22 \\
\hline & J2-621-IGT8 & 1.88 & 1.73 & 365 & 34 & 2.9 & 7.6 & 19 \\
\hline & Endmember & - & 2.88 & 634 & 56 & 4.4 & 12 & 30 \\
\hline Shrimp Hole (2012) & J2-617-IGT1 & 2.01 & 0.29 & 51.8 & 4.6 & $<1$ & $<1$ & $<10$ \\
\hline Bottom Seawater & & 2.25 & 0 & 0 & 0 & 0 & 0 & 0 \\
\hline
\end{tabular}


Table 4. Measured carbon species $\delta^{13} \mathrm{C}$ values in vent fluids at the Von Damm vent field.

\begin{tabular}{llccccc}
\hline \multicolumn{1}{c}{ Vent (Year) } & Sample & $\begin{array}{c}\delta^{15} \mathrm{C}_{\mathrm{CO} 2} \\
(\%)\end{array}$ & $\begin{array}{c}\delta^{15} \mathrm{C}_{\mathrm{CH} 4} \\
(\%)\end{array}$ & $\begin{array}{c}\delta^{15} \mathrm{C}_{2} \mathrm{H}_{6} \\
(\%)\end{array}$ & $\begin{array}{c}\delta^{15} \mathrm{C}_{3} \mathrm{H}_{8} \\
(\% \%)\end{array}$ & $\begin{array}{c}\delta^{15} \mathrm{C}_{6} \mathrm{H}_{6} \\
(\% \%)\end{array}$ \\
\hline East Summit (2012) & J2-612-IGT2 & 0.82 & -15.6 & -12.9 & -9.8 & - \\
& J2-616-IGT8 & 0.94 & -15.3 & -12.3 & - & - \\
East Summit (2013) & N55-IGT4 & $-\|$ & -15.4 & - & - & - \\
& N56-IGT6 & - & -15.6 & - & - & - \\
White Castle (2012) & J2-616-IGT1 & 1.47 & -15.6 & - & - & - \\
Bartizan (2013) & N61-IGT4 & - & -15.7 & - & - & - \\
& N61-IGT6 & - & -15.7 & - & - & - \\
Twin Peaks (2013) & N60-IGT7 & - & -15.7 & -12.8 & -9.2 & - \\
& N60-IGT8 & - & -15.5 & -12.9 & -10.1 & -19.6 \\
Ginger Castle (2012) & J2-617-IGT4 & 2.17 & -15.8 & -13.2 & -10.8 & - \\
Ravelin \#1 (2012) & J2-617-IGT2 & 1.36 & -15.1 & - & - & - \\
& J2-617-IGT6 & 1.94 & -15.6 & - & - & - \\
Arrow Loop \#1 (2012) & J2-616-IGT6 & 1.88 & -15.7 & -12.5 & - & -17.9 \\
West Summit (2012) & J2-621-IGT1 & 3.30 & -15.6 & -12.6 & - & -17.7 \\
& J2-621-IGT4 & 3.57 & -15.1 & - & - & - \\
Old Man Tree (2012) & J2-612-IGT8 & 2.86 & -15.0 & -12.6 & -11.6 & - \\
& J2-612-IGT6 & 2.57 & -15.2 & - & - & - \\
Ravelin \#2 (2012) & J2-621-IGT2 & 3.79 & -15.1 & -12.9 & -9.7 & - \\
& J2-621-IGT8 & 3.30 & -15.4 & -12.7 & - & -19.3 \\
Shrimp Hole (2012) & J2-617-IGT1 & 1.07 & -15.1 & - & - & \\
Bottom Seawater & & 0.90 & - & - & - & - \\
\#1-- not determined & & & & & & -
\end{tabular}



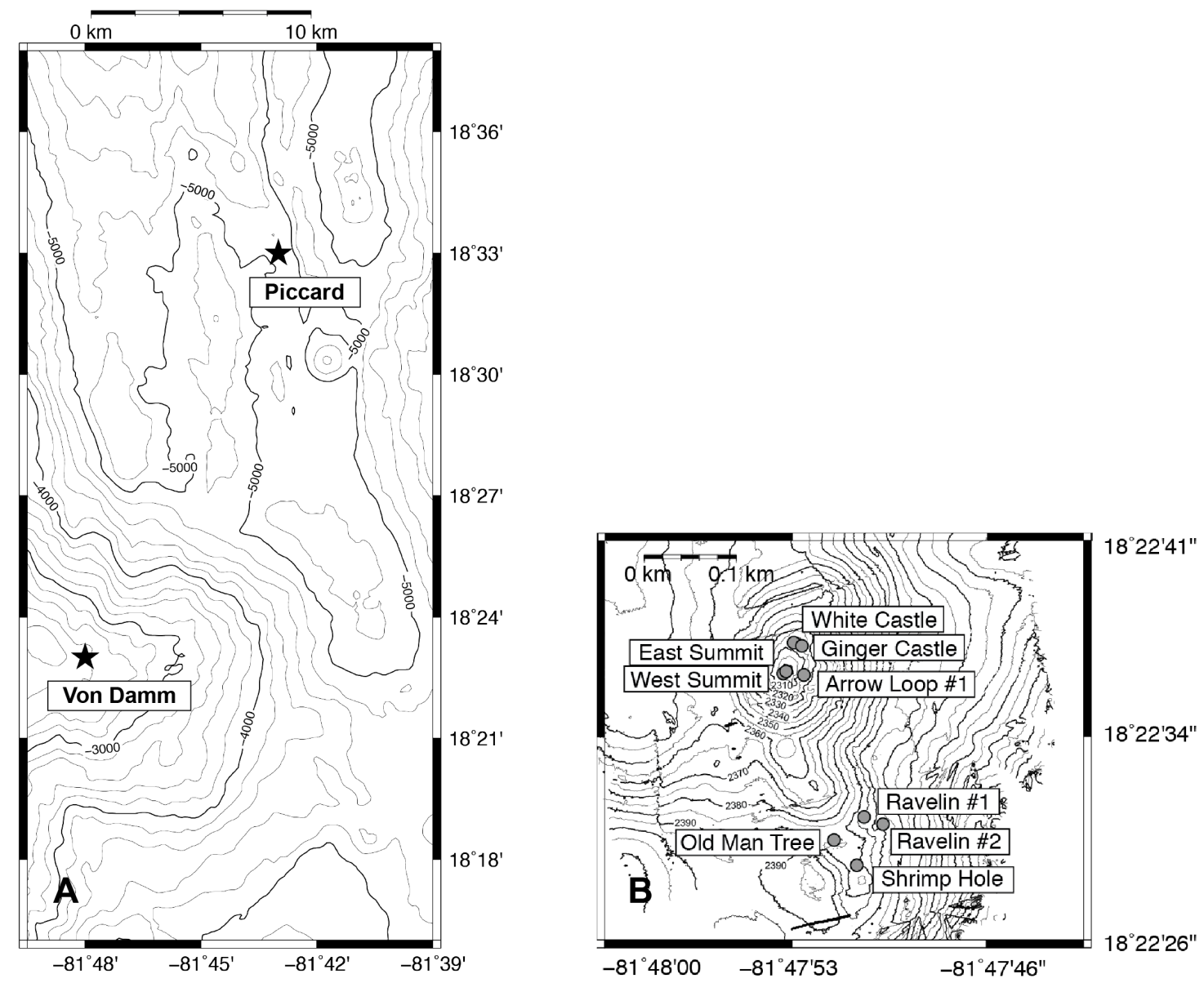

Figure 1. Map of the Mid-Cayman Rise (A), with the Von Damm and Piccard vent fields indicated by stars. Map of the Von Damm vent field (B), with individual orifice locations marked. 

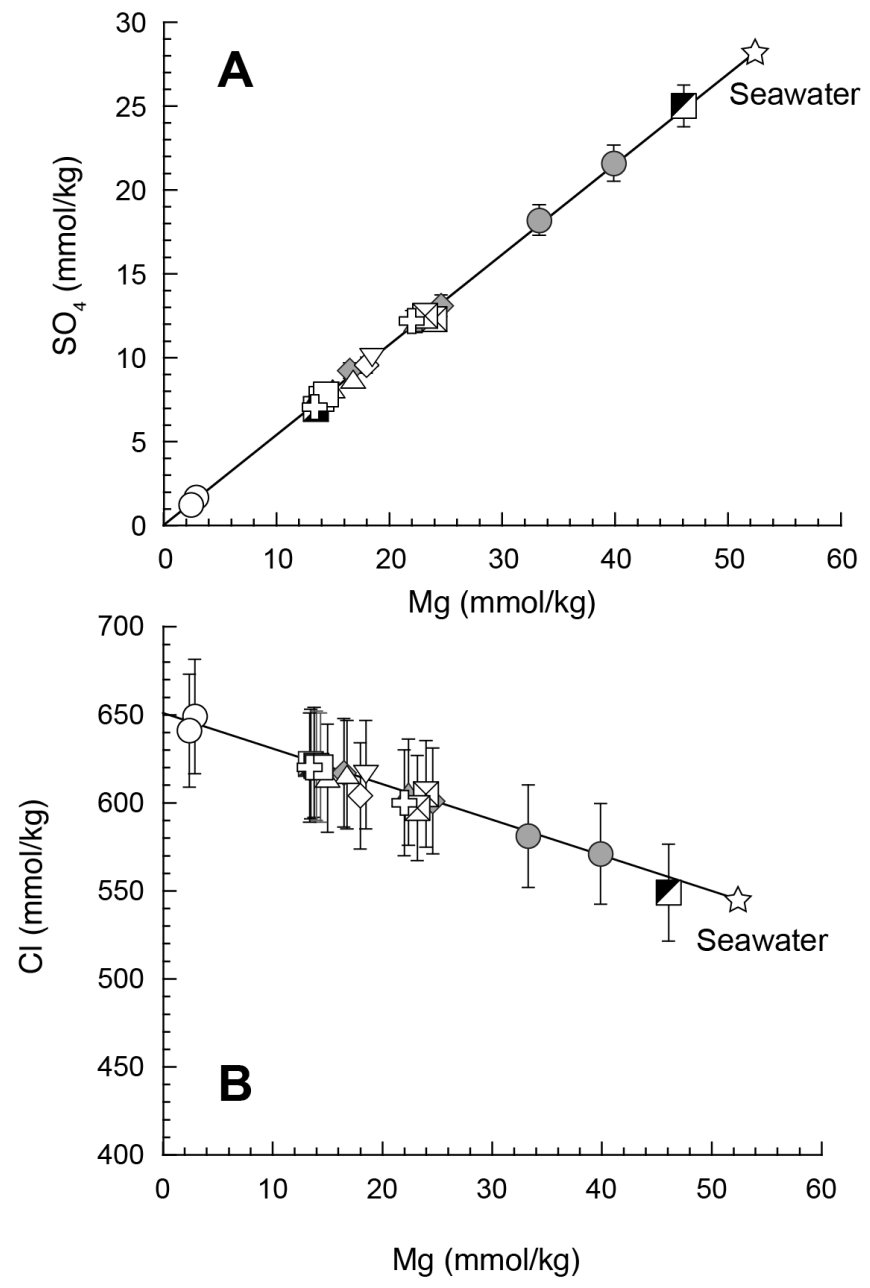

East Summit (2012)

East Summit (2013)

White Castle (2012)

$\checkmark$ Bartizan (2013)

$\triangle$ Twin Peaks (2013)

$\diamond$ Ginger Castle (2012)

$\triangle$ Ravelin \#1 (2012)

$\nabla$ Arrow Loop \#1 (2012)

$\nabla$ West Summit (2012)

$\square$ Old Man Tree (2012)

ऍ Ravelin \#2 (2012)

V Shrimp Hole (2012)

Figure 2. Measured $\mathrm{Mg}$ versus measured $\mathrm{SO}_{4}(\mathrm{~A})$ and $\mathrm{Cl}(\mathrm{B})$ for all fluids sampled at the Von Damm vent field in 2012 (open symbols) and 2013 (shaded symbols). The extrapolated zero-Mg endmember for the 2012 East Summit sample is indicated by the line. $2 \sigma$ errors are shown. 

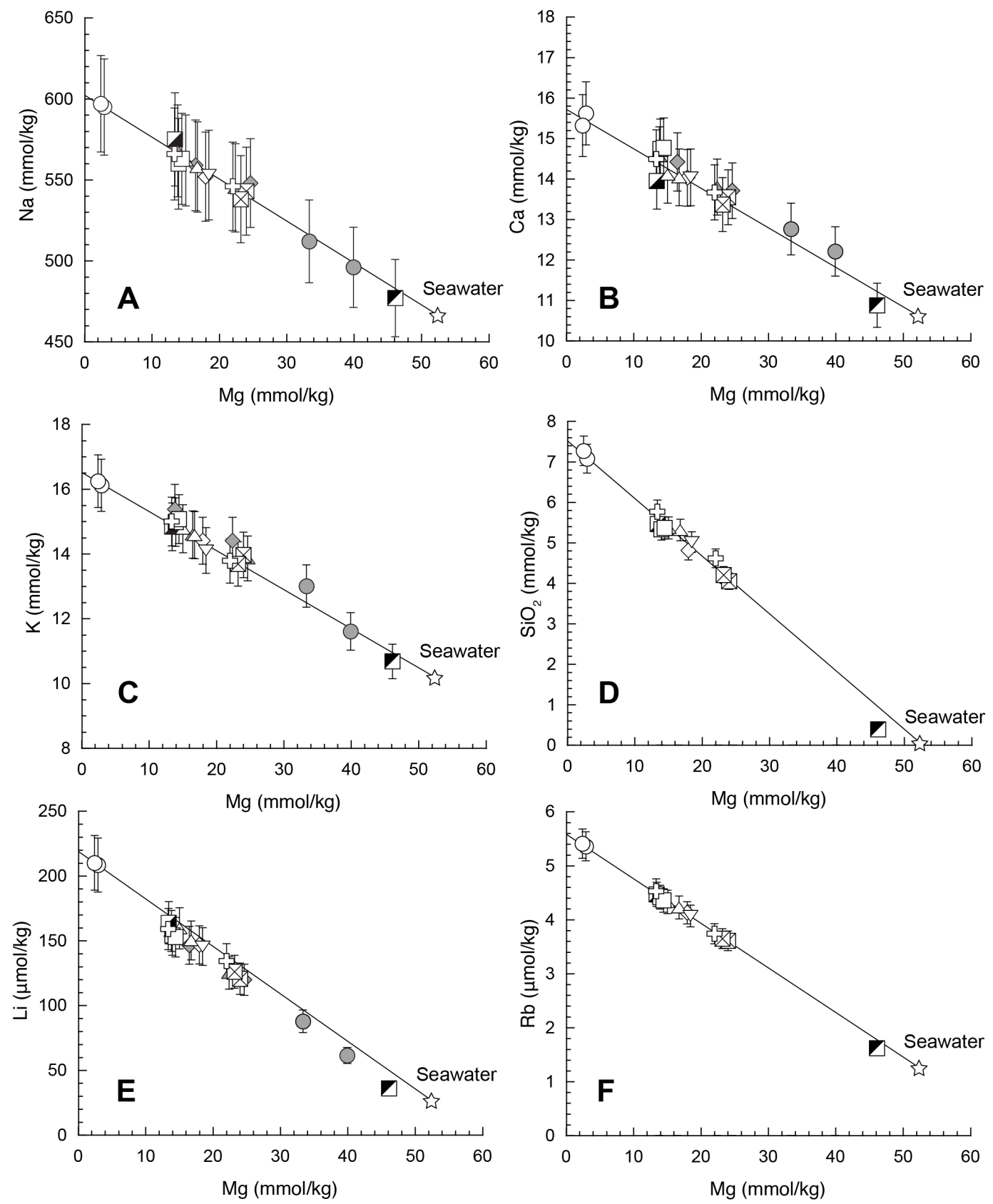

\begin{tabular}{|lll|}
\hline$\bigcirc$ East Summit (2012) & $\triangle$ Twin Peaks (2013) & $\square$ West Summit (2012) \\
$\bigcirc$ East Summit (2013) & $\diamond$ Ginger Castle (2012) & $\square$ Old Man Tree (2012) \\
$\square$ White Castle (2012) & $\triangle$ Ravelin \#1 (2012) & ß Ravelin \#2 (2012) \\
$\diamond$ Bartizan (2013) & $\nabla$ Arrow Loop \#1 (2012) & $\square$ Shrimp Hole (2012)
\end{tabular}

Figure 3. Measured $\mathrm{Mg}$ versus measured $\mathrm{Na}(\mathrm{A}), \mathrm{Ca}(\mathrm{B}), \mathrm{K}(\mathrm{C}), \mathrm{SiO}_{2}(\mathrm{D}), \mathrm{Li}(\mathrm{E})$, and $\mathrm{Rb}(\mathrm{F})$ for all fluids sampled at the Von Damm vent field in 2012 (open symbols) and 2013 (shaded symbols). The extrapolated zero-Mg endmember for the 2012 East Summit sample is indicated by the line in each plot. $2 \sigma$ errors are shown. 

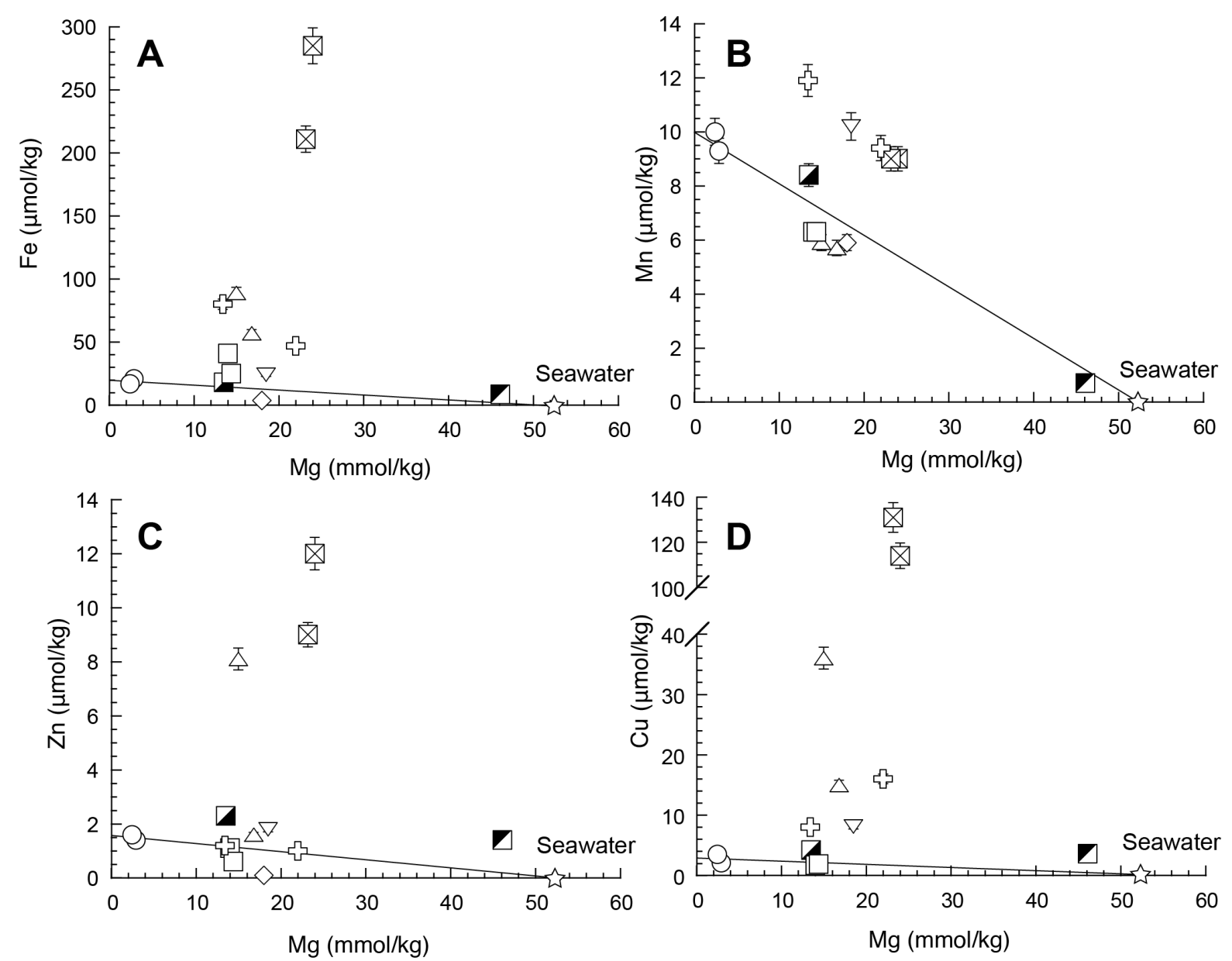

\begin{tabular}{|ll|}
\hline$\bigcirc$ East Summit (2012) & $\square$ West Summit (2012) \\
$\square$ White Castle (2012) & $\square$ Old Man Tree (2012) \\
$\diamond$ Ginger Castle (2012) & ß Ravelin \#2 (2012) \\
$\triangle$ Ravelin \#1 (2012) & $\square$ Shrimp Hole (2012) \\
$\nabla$ Arrow Loop \#1 (2012) & \\
\hline
\end{tabular}

Figure 4. Measured $\mathrm{Mg}$ versus measured $\mathrm{Fe}(\mathrm{A}), \mathrm{Mn}(\mathrm{B}), \mathrm{Zn}(\mathrm{C})$, and $\mathrm{Cu}(\mathrm{D})$ for all fluids sampled at the Von Damm vent field in 2012 (open symbols) and 2013 (shaded symbols). The extrapolated zero-Mg endmember for the 2012 East Summit sample is indicated by the line in each plot. $2 \sigma$ errors are shown. 

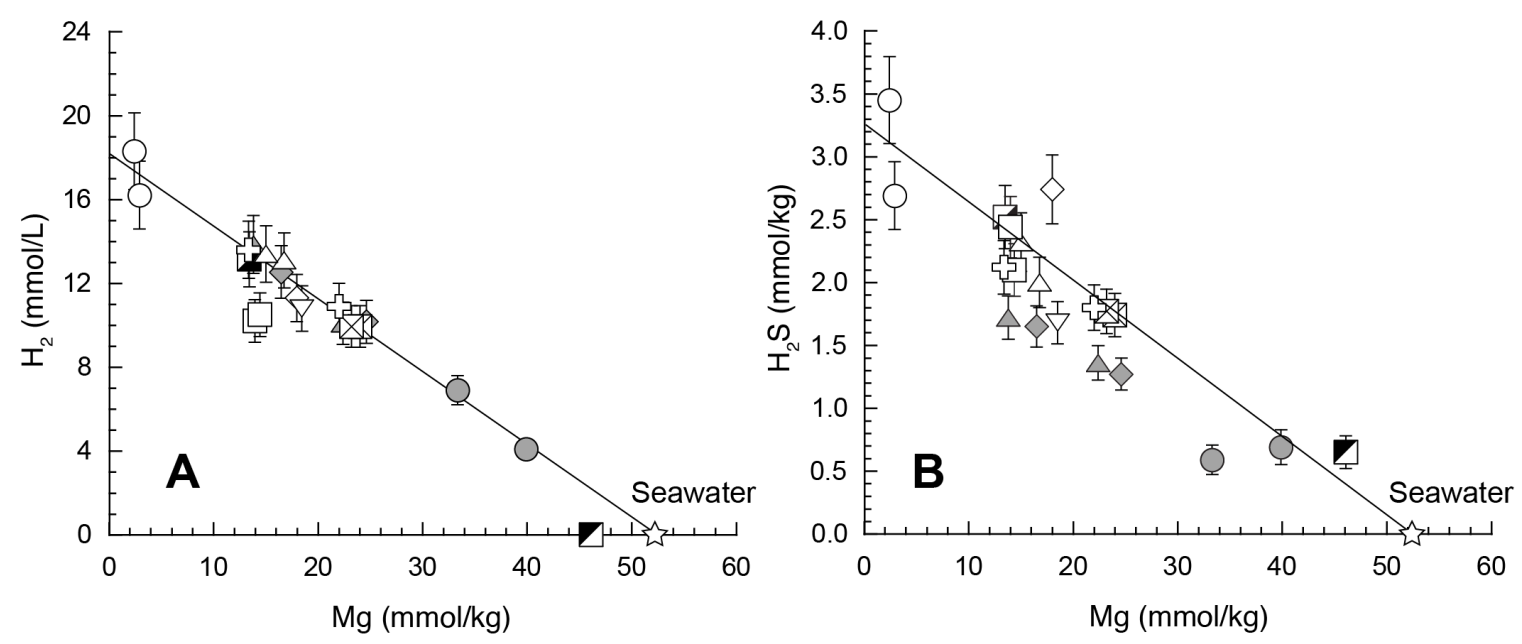

\begin{tabular}{lll}
$\bigcirc$ East Summit (2012) & $\triangle$ Twin Peaks (2013) & $\square$ West Summit (2012) \\
$\bigcirc$ East Summit (2013) & $\diamond$ Ginger Castle (2012) & $\square$ Old Man Tree (2012) \\
$\square$ White Castle (2012) & $\triangle$ Ravelin \#1 (2012) & $\biguplus$ Ravelin \#2 (2012) \\
$\diamond$ Bartizan (2013) & $\nabla$ Arrow Loop \#1 (2012) & $\square$ Shrimp Hole (2012) \\
\hline
\end{tabular}

Figure 5. Measured $\mathrm{Mg}$ versus measured dissolved $\mathrm{H}_{2}(\mathrm{~A})$ and $\mathrm{H}_{2} \mathrm{~S}$ (B) for all fluids sampled at the Von Damm vent field in 2012 (open symbols) and 2013 (shaded symbols). The extrapolated zero-Mg endmember for the 2012 East Summit sample is indicated by the line in each plot. $2 \sigma$ errors are shown. 

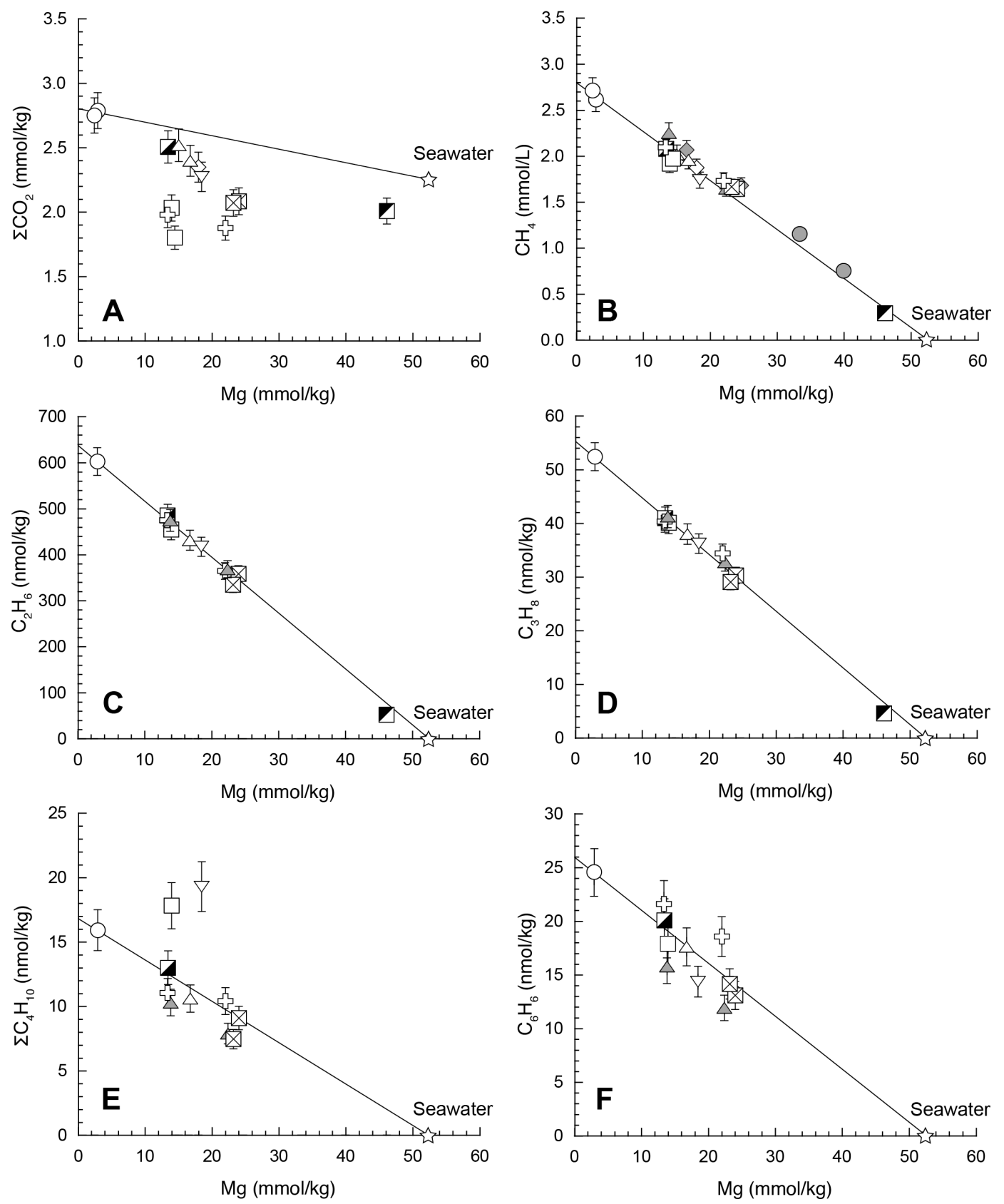

\begin{tabular}{|lll|}
\hline$\bigcirc$ East Summit (2012) & $\triangle$ Twin Peaks (2013) & $\square$ West Summit (2012) \\
$\bigcirc$ East Summit (2013) & $\diamond$ Ginger Castle (2012) & $\square$ Old Man Tree (2012) \\
$\square$ White Castle (2012) & $\triangle$ Ravelin \#1 (2012) & ß Ravelin \#2 (2012) \\
$\diamond$ Bartizan (2013) & $\nabla$ Arrow Loop \#1 (2012) & $\square$ Shrimp Hole (2012) \\
\hline
\end{tabular}

Figure 6. Measured $\mathrm{Mg}$ versus measured dissolved $\Sigma \mathrm{CO}_{2}(\mathrm{~A}), \mathrm{CH}_{4}(\mathrm{~B}), \mathrm{C}_{2} \mathrm{H}_{6}(\mathrm{C}), \mathrm{C}_{3} \mathrm{H}_{8}(\mathrm{D})$, $\Sigma \mathrm{C}_{4} \mathrm{H}_{10}(\mathrm{E})$, and $\mathrm{C}_{6} \mathrm{H}_{6}(\mathrm{~F})$ for all fluids sampled at the Von Damm vent field in 2012 (open symbols) and 2013 (shaded symbols). The extrapolated zero-Mg endmember for the 2012 East Summit sample is indicated by the line in each plot. $2 \sigma$ errors are shown. 


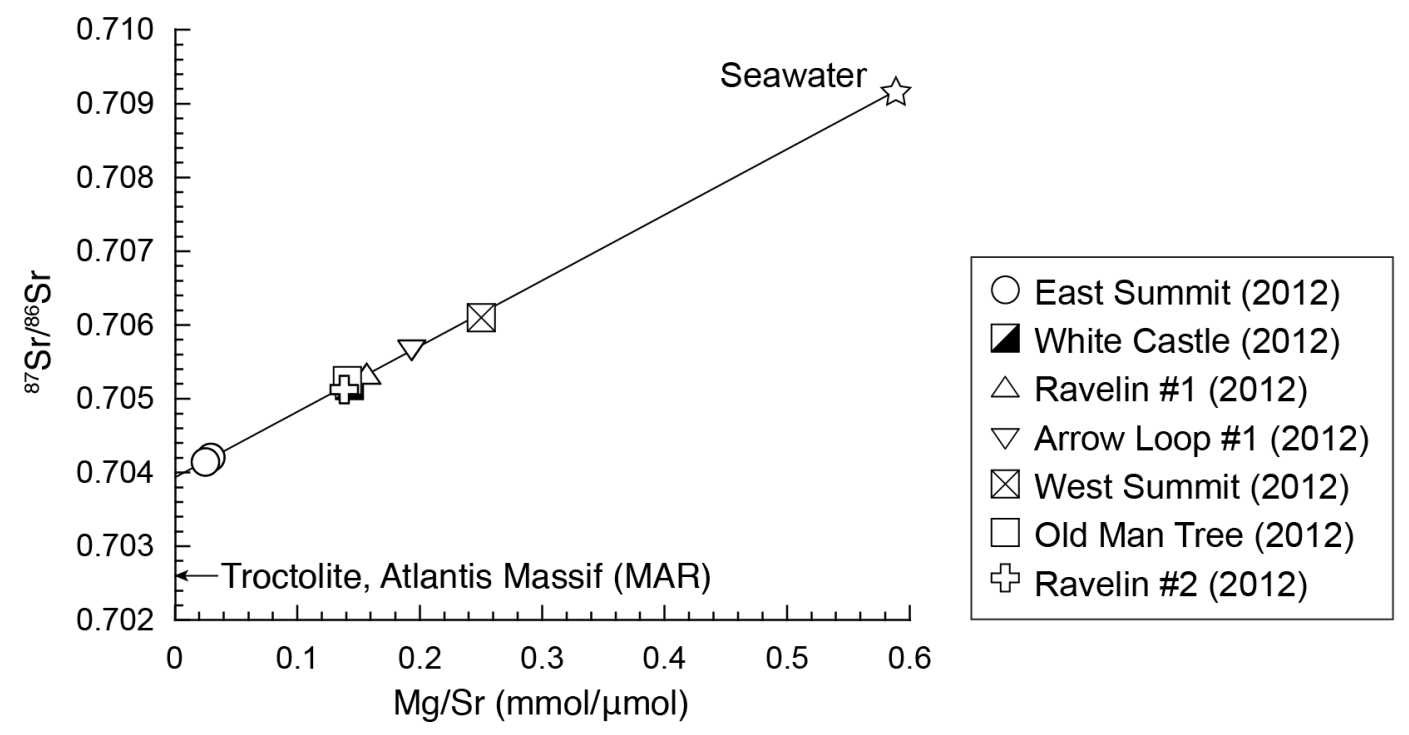

Figure 7. Measured $\mathrm{Sr} / \mathrm{Mg}$ vs. ${ }^{87} \mathrm{Sr} /{ }^{86} \mathrm{Sr}$ ratio for selected fluids at the Von Damm vent field (Albarède et al., 1981). The extrapolated zero-Sr/Mg endmembers for the East Summit 2012 orifice is indicated with a line. The average ${ }^{87} \mathrm{Sr} /{ }^{86} \mathrm{Sr}$ ratio determined in troctolites from IODP Site U1309 on the Atlantis Massif, MAR, is shown for comparison (CASEY, 1997; GODARD et al., 2009). $2 \sigma$ errors are smaller than symbols. 

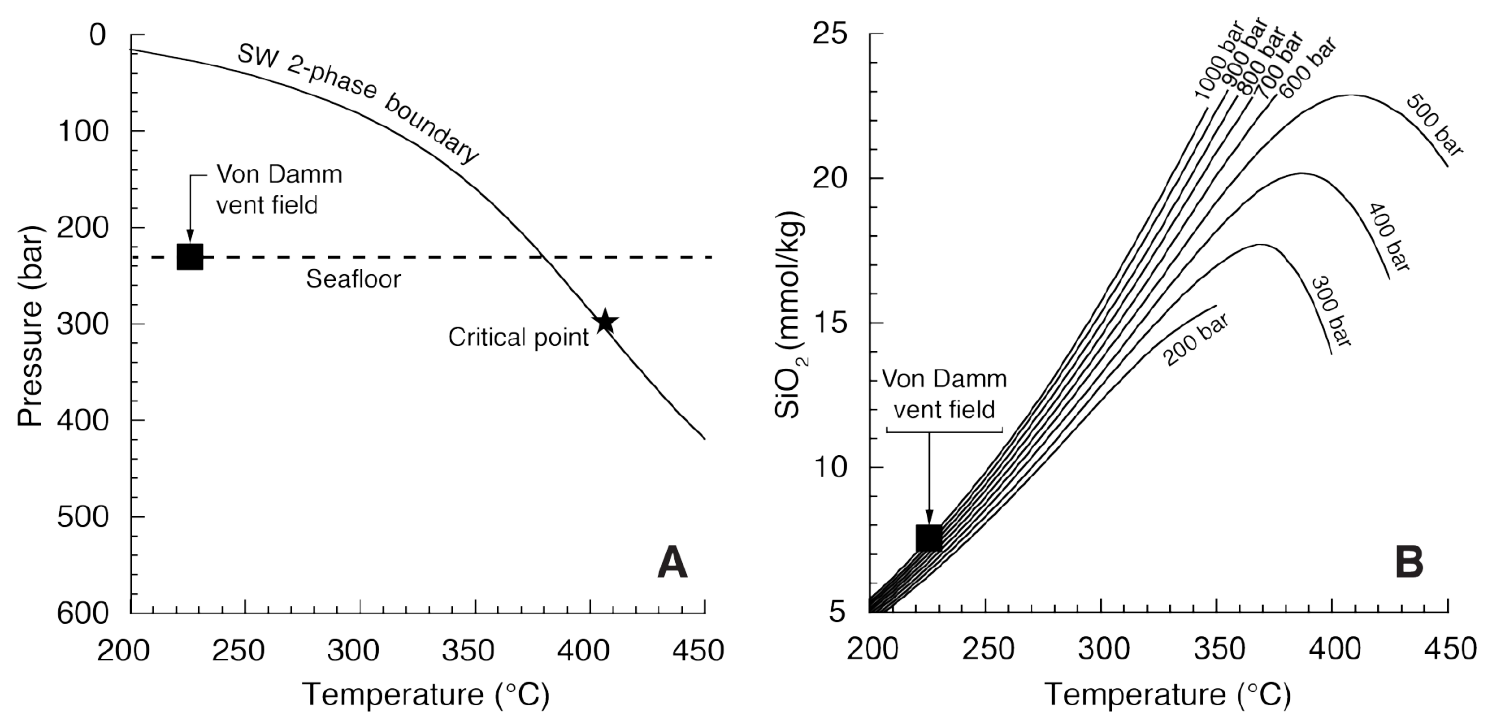

Figure 8. Plot of maximum sampled temperature and pressure conditions at the Von Damm vent field (A). The curve represents the 2-phase boundary of seawater (from BISCHOFF AND Rosenbauer, 1985). Plot of endmember $\mathrm{SiO}_{2}$ content of the East Summit fluid (B). Curves represent quartz saturation in seawater as a function of temperature and pressure (VON DAMM et al., 1991). 


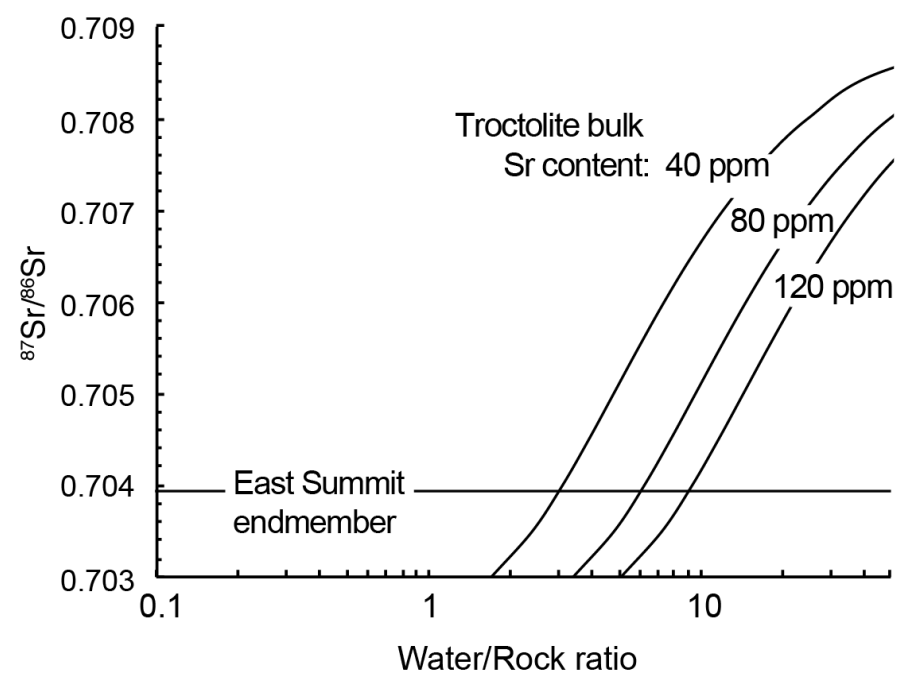

Figure 9. Curved lines indicate estimated $\mathrm{w} / \mathrm{r}$ mass ratios as a function of the fluid $\mathrm{Sr}$ isotope content and bulk Sr abundance in the troctolite protolith, from IODP Site U1309 on the Atlantis Massif, MAR (CASEY, 1997; GoDARD et al., 2009). At Von Damm, dissolved Sr abundances and ${ }^{87} \mathrm{Sr} /{ }^{86} \mathrm{Sr}$ ratios in the 2012 East Summit endmember fluid indicate a $\mathrm{w} / \mathrm{r}$ mass ratio between 2 and 6. This variability is due to variation of bulk $\mathrm{Sr}$ in the troctolite, which can range from 40 to $120 \mathrm{ppm}$, and averages $80 \mathrm{ppm}$. 


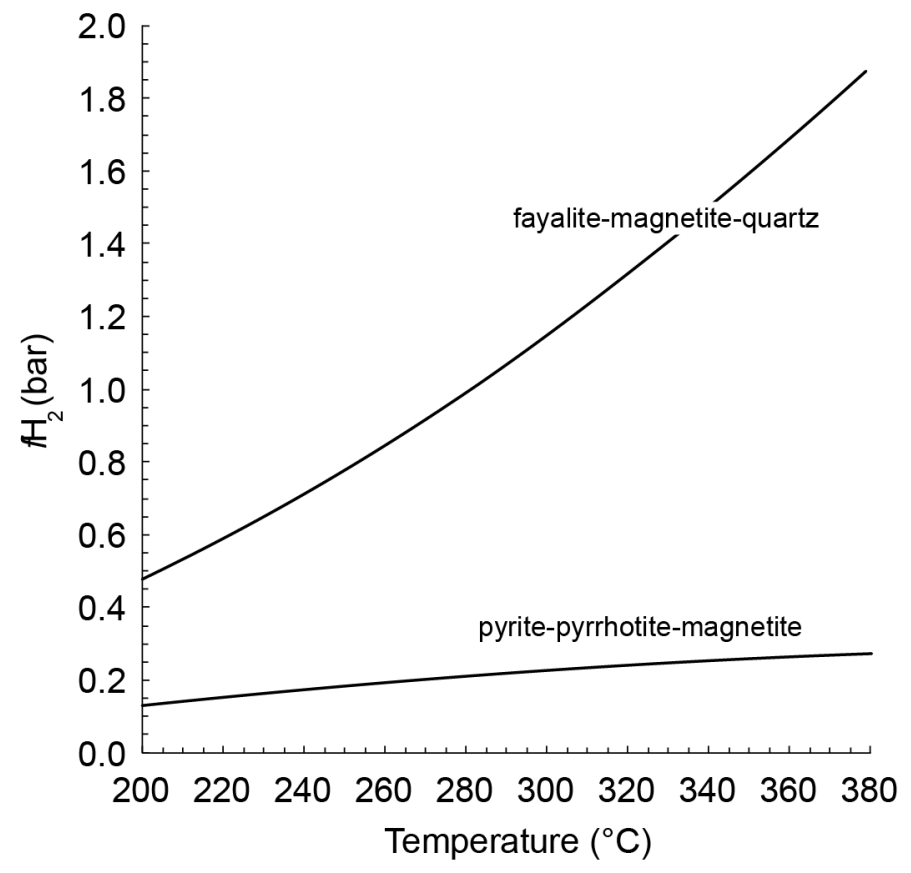

Figure 10. $f \mathrm{H}_{2}$ variability as a function of temperature for the FMQ and PPM buffers, 500 bar. 


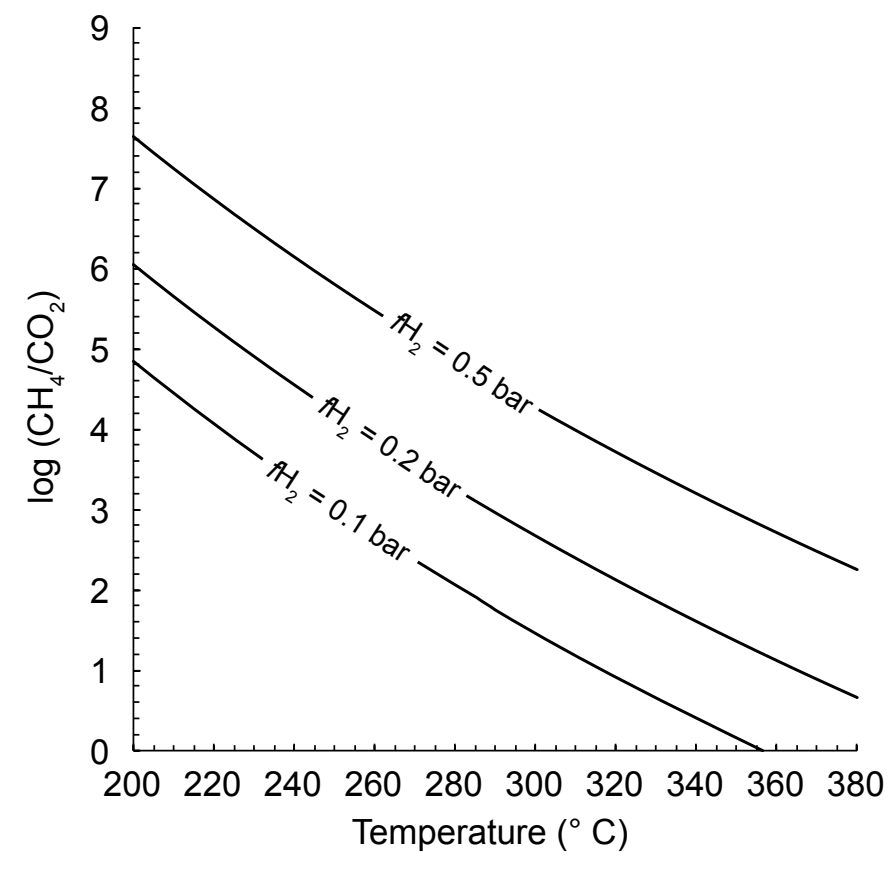

Figure 11. Modeled $\mathrm{CH}_{4} / \mathrm{CO}_{2}$ ratios as a function of temperature and redox. Model conditions are as described in Fig. 7 and in the text. 

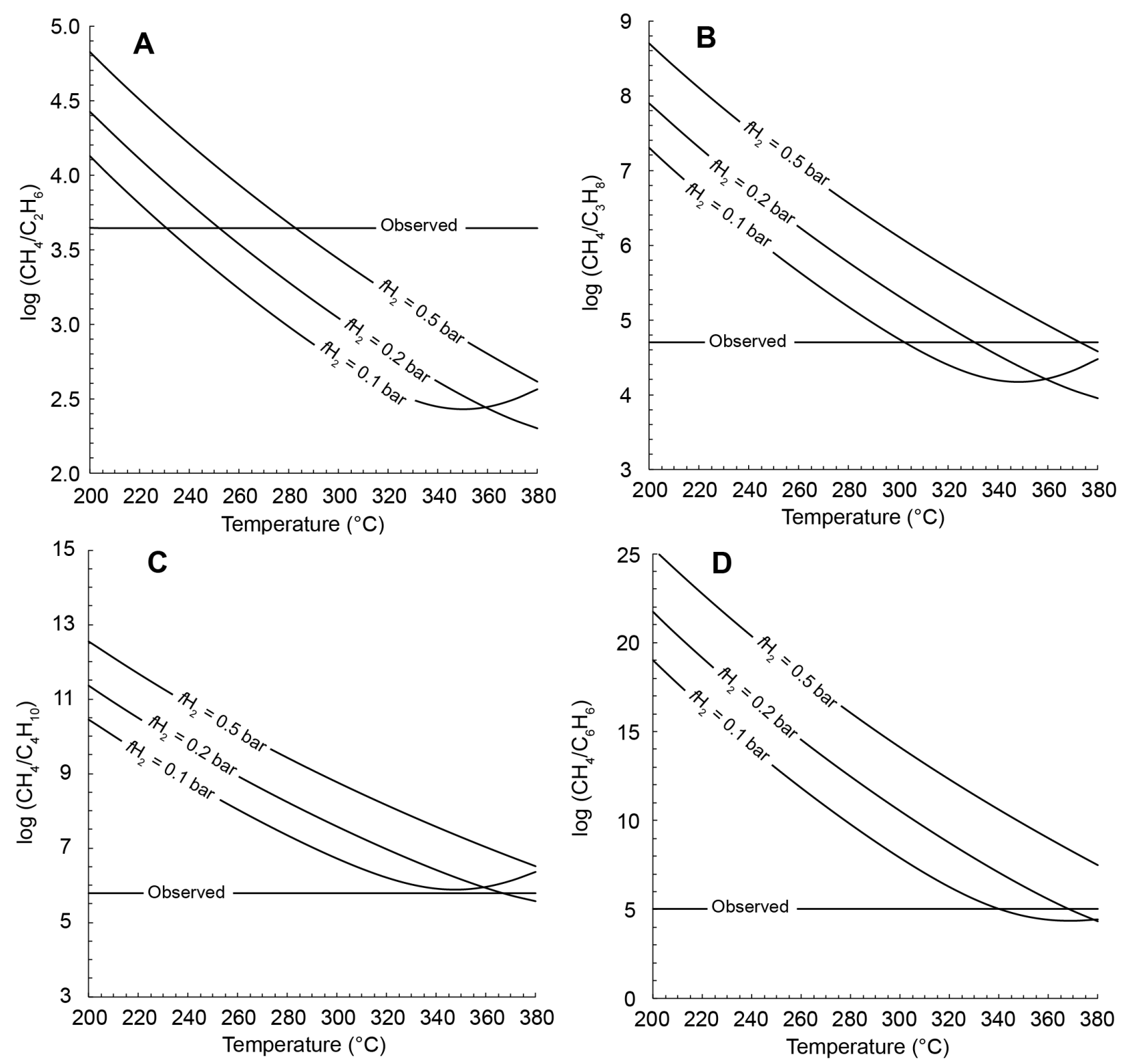

Figure 12. Comparison of observed $\mathrm{CH}_{4} / \mathrm{C}_{2} \mathrm{H}_{6}(\mathrm{~A}), \mathrm{CH}_{4} / \mathrm{C}_{3} \mathrm{H}_{8}(\mathrm{~B}), \mathrm{CH}_{4} / \mathrm{n}-\mathrm{C}_{4} \mathrm{H}_{10}(\mathrm{C})$, and $\mathrm{CH}_{4} / \mathrm{C}_{6} \mathrm{H}_{6}$ (D) ratios in Von Damm East Summit fluids relative to ratios modeled at thermodynamic equilibrium as a function of temperature and redox. Three redox scenarios are shown for each ratio, and each curved line represents a fixed $f \mathrm{H}_{2}$ of $0.1,0.2$, and 0.5 bar. All model runs are $100 \%$ gas phase, and were conducted at a pressure of 500 bar and with total carbon set to $10 \mathrm{~mol}$ carbon per L volume. 


\section{Plain-polarized light}
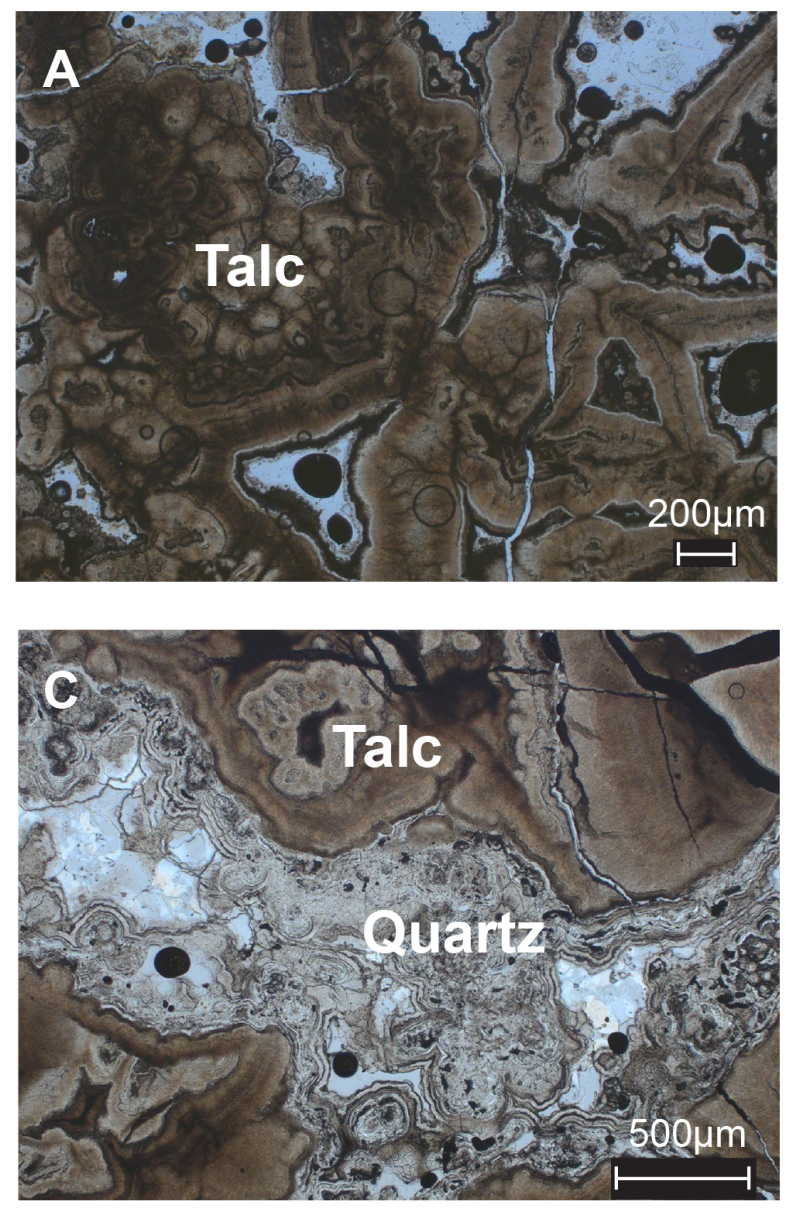

\section{Cross-polarized light}
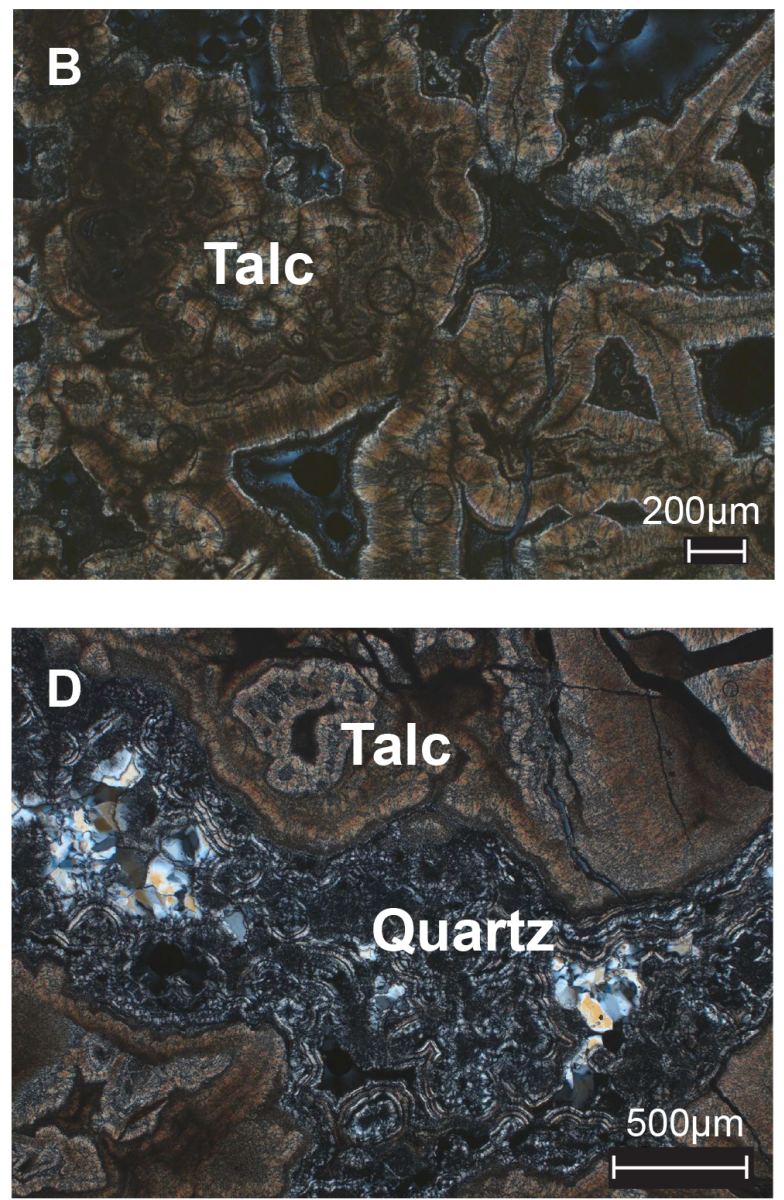

Figure 13. Photomicrographs of Von Damm deposit thin sections, of sample J2-612-15 (A and B) and sample J2-612-59 (C and D) in plain- (A and C) and cross-polarized light (B and D). 

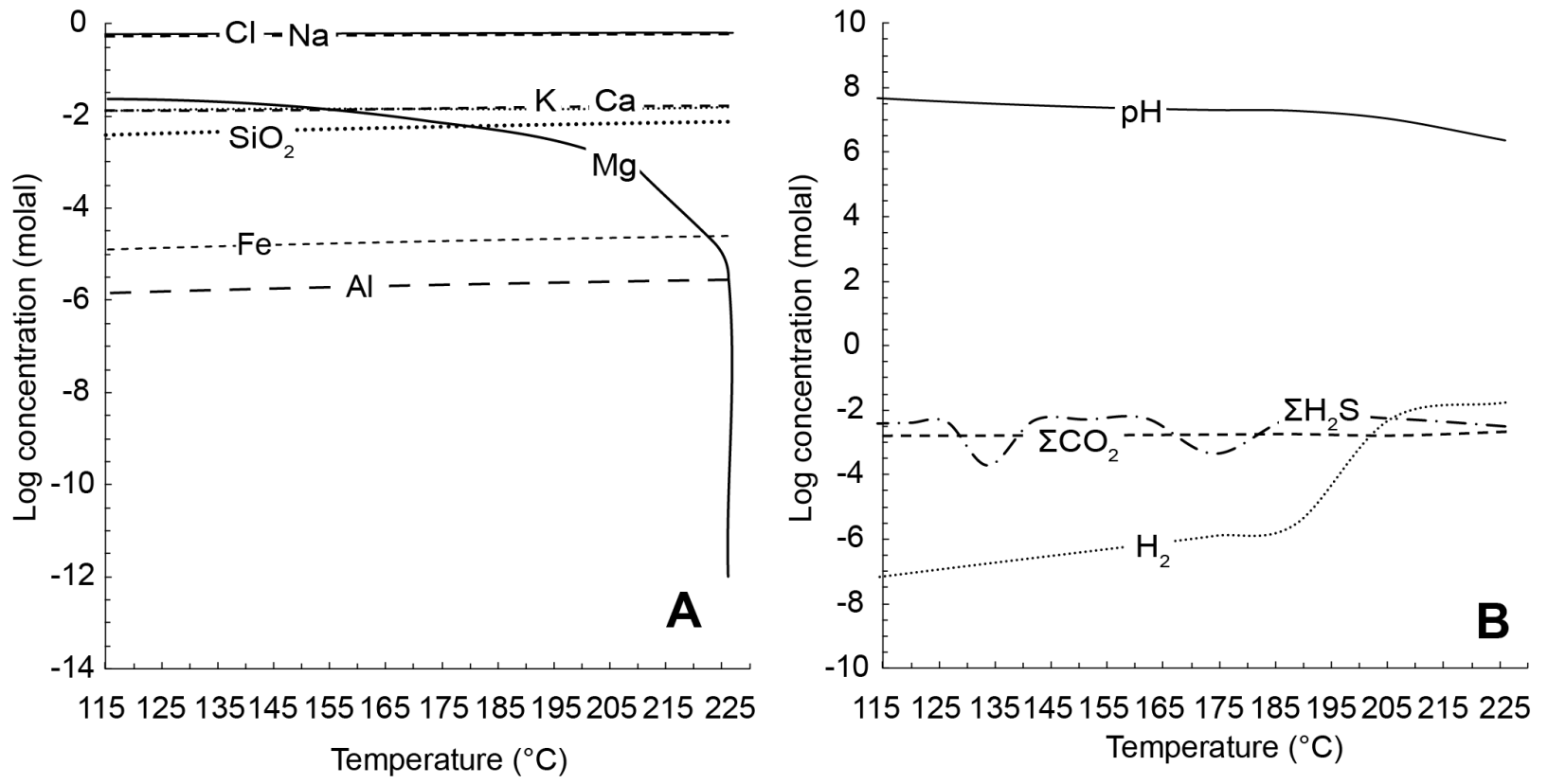

Figure 14. Results of thermodynamic reaction path modeling for mixing between equal volumes of a $226^{\circ} \mathrm{C}$ hydrothermal fluid and $2^{\circ} \mathrm{C}$ seawater that does not allow mineral precipitation. Dissolved inorganic species (A) and volatiles and $\mathrm{pH}(\mathrm{B})$ vary as a function of mixing extent, shown here as shifts in fluid temperature. 

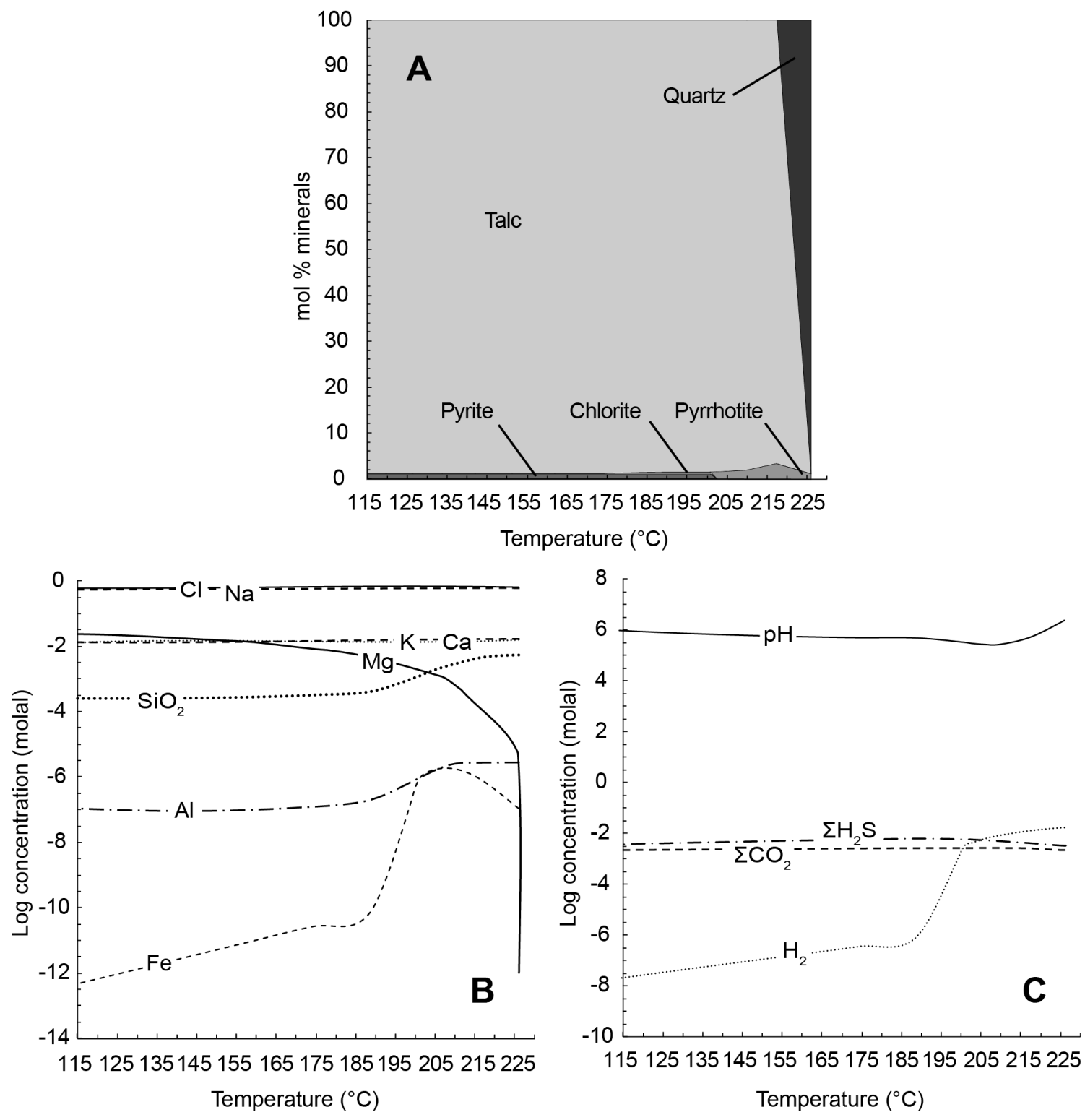

Figure 15. Results of thermodynamic reaction path modeling for mixing between equal volumes of a $226^{\circ} \mathrm{C}$ hydrothermal fluid and $2{ }^{\circ} \mathrm{C}$ seawater that allows mineral precipitation. Predicted precipitating mineral phases (A) are illustrated in terms of relative mol \% as they vary with mixing extent, shown here as shifts in fluid temperature (mol \% is normalized to total moles minerals precipitated at each temperature). Dissolved inorganic species (B) and volatiles and $\mathrm{pH}$ (C) also vary as a function of mixing extent, shown here as shifts in fluid temperature. 


\section{APPENDIX}

Metal concentrations and dissolved $\mathrm{Mg}, \mathrm{Rb}, \mathrm{Sr}$, and $\mathrm{SiO}_{2}$ species were determined with inductively-coupled plasma mass spectrometry using a ThermoElectron Element 2 instrument at WHOI. Dissolved species were analyzed on filtered dissolved samples only (Table 1), while metals were determined separately on dissolved, filter, and dregs fractions (Table A1, Table A2, and Table A3). Masses analyzed included ${ }^{25} \mathrm{Mg},{ }^{85} \mathrm{Rb},{ }^{88} \mathrm{Sr}$ (low resolution) and ${ }^{27} \mathrm{Al},{ }^{28} \mathrm{Si},{ }^{55} \mathrm{Mn}$, ${ }^{56} \mathrm{Fe},{ }^{66} \mathrm{Zn},{ }^{65} \mathrm{Cu}$ (medium resolution) on 5000x diluted aliquots for the dissolved fraction. Masses analyzed included ${ }^{27} \mathrm{Al},{ }^{28} \mathrm{Si},{ }^{56} \mathrm{Fe},{ }^{66} \mathrm{Zn},{ }^{65} \mathrm{Cu}$ (medium resolution) on $100 \mathrm{x}$ diluted aliquots and undiluted aliquots for the dissolved, dregs, and filter fractions.

Multi-element 5 point standards ( $0.2 \mathrm{ppb}, 1 \mathrm{ppb}, 10 \mathrm{ppb}, 100 \mathrm{ppb}, 500 \mathrm{ppb}$ ) were prepared in $5 \mathrm{wt} \%$ Optima $\mathrm{HNO}_{3}$ using Specpure ${ }^{\circledR}$ certified stock solutions. Two sets of standards were prepared, including one set in Milli-Q water and one set that was matrix matched to the $100 \mathrm{x}$ diluted aliquots using $\mathrm{NaCl}$ (i.e. $\mathrm{Cl}=6 \mathrm{mmol} / \mathrm{kg}$ ). All samples and standards were spiked to $1 \mathrm{ppb}$ with ${ }^{45} \mathrm{Sc}$ and ${ }^{115} \mathrm{In}$, and the intensity of elemental signals were normalized to those of ${ }^{45} \mathrm{Sc}$ or ${ }^{115} \mathrm{In}$ in low or medium resolution (whichever spike was nearest in mass to the isotope measured) throughout the course of the run. Ambient $2300 \mathrm{~m}$ bottom seawater collected from a Niskin bottle on the CTD rosette was analyzed as an unknown sample. A working blank was collected for each of the three fractions, and samples were blank-corrected during offline processing. The detection limit for each species is defined as $50 \%$ of the sum of the blank signal +0.2 ppb standard signal. 
Table A1. Measured metal concentrations in the 'dissolved' fraction of Von Damm fluids.

\begin{tabular}{lccccccc}
\hline \multicolumn{1}{c}{ Vent (Year) } & Sample & $\mathrm{Mg}$ & $\mathrm{Al}$ & $\mathrm{Mn}$ & $\mathrm{Fe}$ & $\mathrm{Zn}$ & $\mathrm{Cu}$ \\
& & $\mathrm{mm} \dagger$ & $\mu \mathrm{m} \dagger$ & $\mu \mathrm{m}$ & $\mu \mathrm{m}$ & $\mu \mathrm{m}$ & $\mu \mathrm{m}$ \\
\hline East Summit (2012) & J2-612-IGT2 & 2.93 & 1.6 & 8.8 & 16 & $\mathrm{BD}$ & $\mathrm{BD}$ \\
East Summit (2012) & J2-616-IGT8 & 2.43 & 1.7 & 9.5 & 11 & 0.60 & $\mathrm{BD}$ \\
White Castle (2012) & J2-616-IGT1 & 13.5 & 2.2 & 8.0 & 8.7 & 1.5 & $\mathrm{BD}$ \\
Ginger Castle (2012) & J2-617-IGT4 & 18.0 & 1.0 & 5.8 & 3.8 & 0.13 & $\mathrm{BD}$ \\
Ravelin \#1 (2012) & J2-617-IGT2 & 16.8 & 2.1 & 5.0 & 15 & $\mathrm{BD}$ & $\mathrm{BD}$ \\
Ravelin \#1 (2012) & J2-617-IGT6 & 15.0 & 0.91 & 5.0 & 7.4 & 3.9 & 2.9 \\
Arrow Loop \#1 (2012) & J2-616-IGT6 & 18.5 & $\mathrm{BD}$ & 9.6 & 6.0 & 0.21 & $\mathrm{BD}$ \\
West Summit (2012) & J2-621-IGT1 & 24.0 & 4.3 & 7.3 & 5.0 & 0.37 & $\mathrm{BD}$ \\
West Summit (2012) & J2-621-IGT4 & 23.2 & 0.81 & 7.7 & 19 & $\mathrm{BD}$ & $\mathrm{BD}$ \\
Old Man Tree & J2-612-IGT8 & 14.0 & 0.75 & 5.8 & 25 & 0.27 & $\mathrm{BD}$ \\
Old Man Tree & J2-612-IGT6 & 14.4 & 0.49 & 5.7 & 15 & $\mathrm{BD}$ & $\mathrm{BD}$ \\
Ravelin \#2 (2012) & J2-621-IGT2 & 13.4 & 4.6 & 11 & 7.8 & 0.29 & $\mathrm{BD}$ \\
Ravelin \#2 (2012) & J2-621-IGT8 & 22.0 & $\mathrm{BD}$ & 8.3 & 4.8 & $\mathrm{BD}$ & $\mathrm{BD}$ \\
Shrimp Hole (2012) & J2-617-IGT1 & 46.1 & 1.0 & 0.23 & 3.1 & 0.68 & $\mathrm{BD}$ \\
\hline
\end{tabular}

$\dagger \mathrm{mm}, \mathrm{mmol} / \mathrm{kg} ; \mathrm{mM}, \mathrm{mmol} / \mathrm{L} ; \mu \mathrm{m}, \mu \mathrm{mol} / \mathrm{kg}$

$¥ ' B D '$ below detection limit of the method 
Table A2. Measured metal concentrations in the 'filter' fraction of Von Damm fluids.

\begin{tabular}{lccccccc}
\hline \multicolumn{1}{c}{ Vent (Year) } & Sample & $\mathrm{Mg}$ & $\mathrm{Al}$ & $\mathrm{Mn}$ & $\mathrm{Fe}$ & $\mathrm{Zn}$ & $\mathrm{Cu}$ \\
& & $\mathrm{mm} \dagger$ & $\mu \mathrm{m} \dagger$ & $\mu \mathrm{m}$ & $\mu \mathrm{m}$ & $\mu \mathrm{m}$ & $\mu \mathrm{m}$ \\
\hline East Summit (2012) & J2-612-IGT2 & 2.93 & 0.11 & 0.024 & 0.32 & 0.12 & 0.66 \\
East Summit (2012) & J2-616-IGT8 & 2.43 & $\mathrm{BD}^{\ddagger}$ & 0.042 & 0.30 & 0.31 & 0.49 \\
White Castle (2012) & J2-616-IGT1 & 13.5 & $\mathrm{BD}$ & 0.028 & 1.3 & 0.16 & 0.62 \\
Ginger Castle (2012) & J2-617-IGT4 & 18.0 & 1.3 & 0.089 & 77 & 14 & 72 \\
Ravelin \#1 (2012) & J2-617-IGT2 & 16.8 & 0.21 & 0.048 & 2.0 & 0.17 & 0.84 \\
Ravelin \#1 (2012) & J2-617-IGT6 & 15.0 & $\mathrm{BD}$ & 0.12 & 13 & 0.28 & 4.5 \\
Arrow Loop \#1 (2012) & J2-616-IGT6 & 18.5 & 0.11 & 0.020 & 0.69 & 0.12 & 0.59 \\
West Summit (2012) & J2-621-IGT1 & 24.0 & 0.13 & 0.12 & 14 & 0.062 & 0.44 \\
West Summit (2012) & J2-621-IGT4 & 23.2 & 0.31 & 0.079 & 9.7 & 0.12 & 0.52 \\
Old Man Tree & J2-612-IGT8 & 14.0 & 0.12 & 0.023 & 0.16 & 0.025 & 0.044 \\
Old Man Tree & J2-612-IGT6 & 14.4 & 0.15 & $\mathrm{BD}$ & 0.069 & 0.061 & 0.094 \\
Ravelin \#2 (2012) & J2-621-IGT2 & 13.4 & 0.21 & 0.14 & 3.6 & 0.13 & 0.34 \\
Ravelin \#2 (2012) & J2-621-IGT8 & 22.0 & $\mathrm{BD}$ & 0.11 & 2.2 & 0.025 & 0.056 \\
Shrimp Hole (2012) & J2-617-IGT1 & 46.1 & 0.16 & $\mathrm{BD}$ & 0.53 & 0.093 & 0.41 \\
\hline †mm, mmol/kg; mM, mmol/L; $\mu$ m, $\mu \mathrm{mmol} / \mathrm{kg}$ & & & & & & \\
†'BD' below detection limit of the method & & & & & &
\end{tabular}


Table A3. Measured metal concentrations in the 'dregs' fraction of Von Damm fluids.

\begin{tabular}{|c|c|c|c|c|c|c|c|}
\hline Vent (Year) & Sample & $\begin{array}{c}\mathrm{Mg} \\
\mathrm{mm} \dagger\end{array}$ & $\begin{array}{c}\mathrm{Al} \\
\mu \mathrm{m} \dagger\end{array}$ & $\begin{array}{l}\mathrm{Mn} \\
\mu \mathrm{m}\end{array}$ & $\begin{array}{l}\mathrm{Fe} \\
\mu \mathrm{m}\end{array}$ & $\begin{array}{l}\mathrm{Zn} \\
\mu \mathrm{m}\end{array}$ & $\begin{array}{l}\mathrm{Cu} \\
\mu \mathrm{m}\end{array}$ \\
\hline East Summit (2012) & J2-612-IGT2 & 2.93 & 1.4 & 0.55 & 4.1 & 1.3 & 1.4 \\
\hline East Summit (2012) & J2-616-IGT8 & 2.43 & 0.92 & 0.62 & 5.6 & 0.72 & 3.0 \\
\hline White Castle (2012) & J2-616-IGT1 & 13.5 & $\mathrm{BD}^{\ddagger}$ & 0.41 & 8.2 & 0.65 & 3.6 \\
\hline Ginger Castle (2012) & J2-617-IGT4 & 18.0 & $-\ddagger$ & - & - & - & - \\
\hline Ravelin \#1 (2012) & J2-617-IGT2 & 16.8 & 1.5 & 0.65 & 39 & 1.4 & 14 \\
\hline Ravelin \#1 (2012) & J2-617-IGT6 & 15.0 & 2.4 & 0.79 & 69 & 4.0 & 29 \\
\hline Arrow Loop \#1 (2012) & J2-616-IGT6 & 18.5 & 2.7 & 0.62 & 18 & 1.5 & 7.5 \\
\hline West Summit (2012) & J2-621-IGT1 & 24.0 & 4.7 & 1.5 & 266 & 12 & 113 \\
\hline West Summit (2012) & J2-621-IGT4 & 23.2 & 17.5 & 1.3 & 183 & 8.8 & 130 \\
\hline Old Man Tree & J2-612-IGT8 & 14.0 & 2.3 & 0.49 & 15 & 0.75 & 1.7 \\
\hline Old Man Tree & J2-612-IGT6 & 14.4 & 1.1 & 0.54 & 9.3 & 0.57 & 1.8 \\
\hline Ravelin \#2 (2012) & J2-621-IGT2 & 13.4 & 5.0 & 0.84 & 68 & 0.73 & 7.7 \\
\hline Ravelin \#2 (2012) & J2-621-IGT8 & 22.0 & 3.1 & 0.97 & 40 & 0.93 & 16 \\
\hline Shrimp Hole (2012) & J2-617-IGT1 & 46.1 & BD & 0.50 & 5.0 & 0.60 & 3.1 \\
\hline
\end{tabular}




\section{REFERENCES}

Albarède, F., Michard, A., Minster, J.F., Michard, G. (1981) ${ }^{86} \mathrm{Sr} /{ }^{87} \mathrm{Sr}$ ratios in hydrothermal waters and deposits from the East Pacific Rise at $21^{\circ} \mathrm{N}$. Earth and Planetary Science Letters 55, 229-236.

Allen, D.E., SEYFrIED JR, W.E. (2003) Compositional controls on vent fluids from ultramafichosted hydrothermal systems at mid-ocean ridges: An experimental study at $400^{\circ} \mathrm{C}, 500$ bars. Geochimica et Cosmochimica Acta 67, 1531-1542.

Allen, D.E., SEYFRIED JR, W.E. (2004) Serpentinization and heat generation: constraints from Lost City and Rainbow hydrothermal systems. Geochimica et Cosmochimica Acta 68, 1347-1354.

Alt, J.C., Anderson, T.F. (1991) Mineralogy and isotopic composition of sulfur in Layer 3 gabbros from the Indian Ocean, Hole 735B. Proceedings of the Ocean Drilling Program, Scientific Results 118, 113-125.

American Public Health Association (1980) Standard methods for the examination of water and wastewater $15^{\text {th }}$ ed., Washington, DC, p. 448.

Amend, J.P., McCollom, T.M., Hentscher, M., BACH, W. (2011) Catabolic and anabolic energy for chemolithoautotrophs in deep-sea hydrothermal systems hosted in different rock types. Geochimica et Cosmochimica Acta 75, 5736-5748.

ARAI, S., ISHIMARU, S., MizUKAMI, T. (2012) Methane and propane micro-inclusions in olivine in titanoclinohumite-bearing dunites from the Sanbagawa high-P metamorphic belt, Japan Hydrocarbon activity in a subduction zone and Ti mobility. Earth and Planetary Science Letters 353-354, 1-11.

BACH, W., BANerJeE, N., Dick, H., BAKER, E. (2002) Discovery of ancient and active hydrothermal systems along the ultra-slow spreading Southwest Indian Ridge $10^{\circ}-16^{\circ} \mathrm{E}$. Geochemistry Geophysics Geosystems 3(7), doi: 10.1029/2001GC000279.

Bach, W., Garrido, C.J., Paulick, H., Harvey, J., Rosner, M. (2004) Seawater-peridotite interactions: First insights from ODP Leg 209, MAR $15^{\circ}$ N. Geochemistry Geophysics Geosystems 5(9), doi: 10.1029/2004GC000744.

BAKer, E.T., Chen, Y., Morgan, J. (1996) The relationship between near-axis hydrothermal cooling and the spreading rate of mid-ocean ridges. Earth and Planetary Science Letters 142(1-2), 137-145. 
Baker, E.T., Edmonds, H.N., Michael, P.J., Bach, W., Dick, H.J.B., SnOw, J.E., Walker, S.L., BANERJEE, N.R., LANGMUIR, C.H. (2004) Hydrothermal venting in magma deserts: The ultraslow-spreading Gakkel and Southwest Indian Ridges. Geochemistry, Geophysics, Geosystems 5(8), doi: 10.1029/2004GC000712.

BAKER, E.T., GERMAN, C.R. (2004) On the global distribution of mid-ocean ridge hydrothermal vent-fields, in: German, C.R., Lin, J., Parson, L.M. (Eds.), Mid-Ocean Ridges: Hydrothermal Interactions Between the Lithosphere and Oceans. AGU Geophysical Monograph, Washington, DC, pp. 245-266.

Ballard, R.D., Bryan, W.B., Davis, K., De Boer, J., DeLong, S., Dick, H., Emery, K.O., Fox, P.J., Hempton, M., Malcolm, F., Melson, W.G., Spydell, K., Stroup, J.B., Thompson, G., Wright, R., UchupI, E. (1979) Geological and geophysical investigation of the Mid-Cayman Rise spreading center: Initial results and observations, in: Talwani, M., Harrison, C.G., Hayes, D.E. (Eds.), Deep Drilling Results in the Atlantic Ocean: Ocean Crust. American Geophysical Union, Washington, D.C., pp. 66-93.

Beaulieu, S.E., Baker, E.T., German, C.R., Maffei, A. (2013) An authoritative global database for active submarine hydrothermal vent fields. Geochemistry Geophysics Geosystems 14, 4892-4905.

Berger, G., Schott, J., Guy, C. (1988) Behavior of Li, Rb and Cs during basalt glass and olivine dissolution and chlorite, smectite and zeolite precipitation from seawater: experimental investigations and modelization between 50 and $300^{\circ} \mathrm{C}$. Chemical Geology 71, 297-312.

Berndt, M.E., Seyfried, J., William E (2002) Calcium and sodium exchange during hydrothermal alteration of calcic plagioclase at $400^{\circ} \mathrm{C}$ and 400 bars. Geochimica et Cosmochimica Acta 57, 4445-4451.

Berndt, M.E., Seyfried, J., William E, Janecky, D.R. (1989) Plagioclase and epidote buffering of cation ratios in mid-ocean ridge hydrothermal fluids: Experimental results in and near the supercritical region. Geochimica et Cosmochimica Acta 53, 2283-2300.

Berndt, M.E., SEyfried, W.E., Beck, J.W. (1988) Hydrothermal Alteration Processes at Midocean Ridges: Experimental and Theoretical Constraints from $\mathrm{Ca}$ and Sr Exchange Reactions and Sr Isotopic Ratios. Journal of Geophysical Research 93, 4573-4583. 
Bischoff, J.L., Dickson, F. (1975) Seawater-basalt interaction at $200^{\circ} \mathrm{C}$ and 500 bars: implications for origin of sea-floor heavy-metal deposits and regulation of seawater chemistry. Earth and Planetary Science Letters 25, 385-397.

BISCHOFF, J.L., RosenBAUER, R.J. (1985) An empirical equation of state for hydrothermal seawater (3.2 percent $\mathrm{NaCl})$. American Journal of Science 285, 725-763.

Boetius, A., German, C.R., Exploring the Habitability of Ice-covered Waterworlds: The DeepSea Hydrothermal System of the Aurora Mount at Gakkel Ridge, Arctic Ocean (8254' N, 6¹5W, $3900 \mathrm{~m})$. Abstract submitted to AGU Fall Meeting 2014.

Bougault, H., Aballea, M., Radford-Knoery, J., Charlou, J., Baptiste, P., Appriou, P., Needham, H., German, C., Miranda, M. (1998) FAMOUS and AMAR segments on the Mid-Atlantic Ridge: ubiquitous hydrothermal $\mathrm{Mn}, \mathrm{CH}_{4}, \delta^{3} \mathrm{He}$ signals along the rift valley walls and rift offsets. Earth and Planetary Science Letters 161, 1-17.

Cann, J.R., Blackman, D.K., Smith, D.K., McAllister, E., Janssen, B., Mello, S., Avgerinos, E., Pascoe, A.R., Escartin, J. (1997) Corrugated slip surfaces formed at ridge-transform intersections on the Mid-Atlantic Ridge. Nature 385, 329-332.

CANNAT, M. (1993) Emplacement of mantle rocks in the seafloor at mid-ocean ridges. Journal of Geophysical Research: Solid Earth (1978-2012) 98, 4163-4172.

CASEY, J.F. (1997) Comparison of major-and trace-element geochemistry of abyssal peridotites and mafic plutonic rocks with basalts from the MARK region of the Mid-Atlantic Ridge. In Karson, J.A., Cannat, M., Miller, D.J., and Elthon, D. (Eds.), Proc. ODP, Sci. Results, 153: College Station, TX (Ocean Drilling Program), 181-241.

Charlou, J.L., Dmitriev, L., Bougault, H., Needham, H.D. (1988) Hydrothermal $\mathrm{CH}_{4}$ between $12^{\circ} \mathrm{N}$ and $15^{\circ} \mathrm{N}$ over the Mid-Atlantic Ridge. Deep Sea Research Part A 35(1), 121-131.

Charlou, J.L., Fouquet, Y., Bougault, H., Donval, J., Etoubleau, J., Jean-Baptiste, P., Dapoigny, A., Appriou, P., Rona, P. (1998) Intense $\mathrm{CH}_{4}$ plumes generated by serpentinization of ultramafic rocks at the intersection of the $15^{\circ} 20^{\prime} \mathrm{N}$ fracture zone and the Mid-Atlantic Ridge. Geochemica et Cosmochimica Acta 62, 2323-2333.

Charlou, J.L., Donval, J.P., Douville, E., Jean-Baptiste, P., Radford-Knoery, J., Fouquet, Y., Dapoigny, A., Stievenard, M. (2000) Compared geochemical signatures and the evolution of Menez Gwen $\left(37^{\circ} 50^{\prime} \mathrm{N}\right)$ and Lucky Strike $\left(37^{\circ} 17^{\prime} \mathrm{N}\right)$ hydrothermal 
fluids, south of the Azores Triple Junction on the Mid-Atlantic Ridge. Chemical Geology 171, 49-75.

Charlou, J.L., Donval, J.P., Fouquet, Y., Jean-Baptiste, P., Holm, N. (2002) Geochemistry of high $\mathrm{H}_{2}$ and $\mathrm{CH}_{4}$ vent fluids issuing from ultramafic rocks at the Rainbow hydrothermal field (36 $\left.16^{\circ} \mathrm{N}, \mathrm{MAR}\right)$. Chemical Geology 191, 345-359.

Charlou, J.L., Donval, J.P., Konn, C., Ondreas, H., Fouquet, Y., Jean-Baptiste, P., FOURR, E. (2010) High production and fluxes of $\mathrm{H}_{2}$ and $\mathrm{CH}_{4}$ and evidence of abiotic hydrocarbon synthesis by serpentinization in ultramafic-hosted hydrothermal systems on the Mid-Atlantic Ridge, Diversity of Hydrothermal Systems on Slow Spreading Ocean Ridges. AGU, Washington, DC, pp. 265-296.

Cheadle, M., John, B., German, C., Kusznir, N. (2012) The Death Throes of Ocean Core Complexes: Examples from the Mid-Cayman Spreading Centre, AGU Fall Meeting, San Fancisco, CA.

Connelly, D.P., Copley, J.T., Murton, B.J., Stansfield, K., Tyler, P.A., German, C.R., Van Dover, C.L., Amon, D., Furlong, M., Grindlay, N., Hayman, N., hNerbach, V.H.u., Judge, M., Le Bas, T., McPhail, S., Meier, A., Nakamura, K.-I., Nye, V., Pebody, M., Pedersen, R.B., Plouviez, S., Sands, C., Searle, R.C., Stevenson, P., TAws, S., WiLcoX, S. (2012) Hydrothermal vent fields and chemosynthetic biota on the world's deepest seafloor spreading centre. Nature Communications 2, 1-9.

Corliss, J.B., Dymond, J., Gordon, L.I., EdMOND, J.M., HeRzen, R.P.V., BALlard, R.D., Green, K., Williams, D., Bainbridge, A., Crane, K., Vanandel, T.H. (1979) Submarine thermal springs on the Galapagos Rift. Science 203, 1073-1083.

CRADDOCK, P.R. (2009) Geochemical tracers of processes affecting the formation of seafloor hydrothermal fluids and deposits in the Manus back-arc basin, Marine Chemistry and Geochemistry. MIT/WHOI Joint Program in Oceanography.

Cruse, A.M., SEewALD, J. (2006) Geochemistry of low-molecular weight hydrocarbons in hydrothermal fluids from Middle Valley, northern Juan de Fuca Ridge. Geochimica et Cosmochimica Acta 70, 2073-2092.

Cruse, A.M., Seewald, J.S. (2010) Low-molecular weight hydrocarbons in vent fluids from the Main Endeavour Field, northern Juan de Fuca Ridge. Geochimica et Cosmochimica Acta 74, 6126-6140. 
Dick, H.J.B., Lin, J., Schouten, H. (2003) An ultraslow-spreading class of ocean ridge. Nature 426, 405-412.

Douville, E., Charlou, J., Oelkers, E., Bienvenu, P., Colon, C., Donval, J., Fouquet, Y., Prieur, D., APPriou, P. (2002) The rainbow vent fluids (36² $\left.14^{\prime} \mathrm{N}, \mathrm{MAR}\right)$ : the influence of ultramafic rocks and phase separation on trace metal content in Mid-Atlantic Ridge hydrothermal fluids. Chemical Geology 184, 37-48.

Drouin, M., Godard, M., Ildefonse, B., Bruguier, O., Garrido, C.J. (2009) Geochemical and petrographic evidence for magmatic impregnation in the oceanic lithosphere at Atlantis Massif, Mid-Atlantic Ridge (IODP Hole U1309D, 30N). Chemical Geology 264, 71-88.

Drummond JR., S.E. (1981) Boiling and Mixing of Hydrothermal Fluids: Chemical Effects on Mineral Precipitation, Geochemistry and Mineralogy. PhD Thesis, Pennsylvania State University.

Edmonds, H.N., Michael, P.J., BAKer, E.T., Connelly, D.P., SnOw, J.E., LANGMuir, C.H., Dick, H., Muhe, R., German, C.R., Graham, D.W. (2003) Discovery of abundant hydrothermal venting on the ultraslow-spreading Gakkel ridge in the Arctic Ocean. Nature 421, 252-256.

Edmonds, H.N. (2010) Chemical signatures from hydrothermal venting on slow spreading ridges, in: Rona, P., Devey, C., Dyment, J., Murton, B. (Eds.), Diversity of Hydrothermal Systems on Slow Spreading Ridges. Geophys. Mono. AGU, Washington DC.

Farquhar, J., Johnston, D.T., Wing, B.A., Habicht, K.S., Canfield, D.E., Airieau, S., THIEMENS, M.H. (2003) Multiple sulphur isotopic interpretations of biosynthetic pathways: implications for biological signatures in the sulphur isotope record. Geobiology 1, 27-36.

FontAine, F.J., CANNAT, M., EscARTin, J. (2008) Hydrothermal circulation at slow-spreading mid-ocean ridges: The role of along-axis variations in axial lithospheric thickness. Geology 36, 759.

Fontaine, F.J., CAnnat, M., Escartin, J., Crawford, W.C. (2014) Along-axis hydrothermal flow at the axis of slow spreading Mid-Ocean Ridges: Insights from numerical models of the Lucky Strike vent field (MAR). Geochemistry Geophysics Geosystems 15, 29182931. 
Foustoukos, D., SEyfried JR, W. (2007) Quartz solubility in the two-phase and critical region of the $\mathrm{NaCl}-\mathrm{KCl}-\mathrm{H} 2 \mathrm{O}$ system: Implications for submarine hydrothermal vent systems at 950’N East Pacific Rise. Geochimica et Cosmochimica Acta 71, 186-201.

Früh-Green, G., Connolly, J., Plas, A., Kelley, D., Grobéty, B. (2004) Serpentinization of Oceanic Peridotitites: Implications for Geochemical Cycles and Biological Activity, in: Wilcock, W., DeLong, E., Kelley, D., Baross, J., Cary, S. (Eds.), The Subseafloor Biosphere at Mid-Ocean Ridges. American Geophysical Union Geophysical Monograph Washington, DC, pp. 119-136.

Galimov, E., Posyagin, V., Prokhorov, V. (1972) Carbon isotope fractionation as a function of temperature in the $\mathrm{CH}_{4}-\mathrm{C}_{2} \mathrm{H}_{6}-\mathrm{C}_{3} \mathrm{H}_{8}-\mathrm{C}_{4} \mathrm{H}_{10}$ system. Geokhimiya $\mathbf{8}, 977-987$.

GALimov, E.M. (2006) Isotope organic geochemistry. Organic Geochemistry 37, 1200-1262.

Gallant, R.M., VON DAMM, K.L. (2006) Geochemical controls on hydrothermal fluids from the Kairei and Edmond Vent Fields, $23^{\circ}-25^{\circ} \mathrm{S}$, Central Indian Ridge. Geochemistry Geophysics Geosystems 7, Q06018.

Gamo, T., Chiba, H., Yamanaka, T., Okudaira, T., Hashimoto, J., Tsuchida, S., Ishibashi, J., Kataoka, S., Tsunogai, U., OKamura, K. (2001) Chemical characteristics of newly discovered black smoker fluids and associated hydrothermal plumes at the Rodriguez Triple Junction, Central Indian Ridge. Earth and Planetary Science Letters 193, 371-379.

GaO, X., ThIEMEns, M.H. (1991) Systematic study of sulfur isotopic composition in iron meteorites and the occurrence of excess ${ }^{33} \mathrm{~S}$ and ${ }^{36} \mathrm{~S}$. Geochimica et Cosmochimica Acta 55, 2671-2679.

German, C.R., Baker, E., Mevel, C., TAmaki, K. (1998) Hydrothermal activity along the southwest Indian ridge. Nature 395, 490-493.

German, C.R., Bowen, A., Coleman, M., Honig, D., Huber, J., Jakuba, M., Kinsey, J., Kurz, M., Leroy, S., McDermott, J.M., Mercier de LéPinay, B., NAKAmura, K., SeEWAld, J.S., Smith, J.L., Sylva, S.P., Van Dover, C.L., Whitcomb, L.L., Yoerger, D.R. (2010) Diverse styles of submarine venting on the ultraslow spreading Mid-Cayman Rise. Proceedings of the National Academy of Sciences 107, 14020.

German, C.R., LIN, J. (2004) The Thermal Structure of the Oceanic Crust, Ridge-Spreading and Hydrothermal Circulation: How Well do we Understand their Inter-Connections?, MidOcean Ridges. American Geophysical Union, pp. 1-18. 
Godard, M., Awaji, S., Hansen, H., Hellebrand, E., Brunelli, D., Johnson, K., Yamasaki, T., Maeda, J., Abratis, M., Christie, D., Kato, Y., Mariet, C., ROSNER, M. (2009) Geochemistry of a long in-situ section of intrusive slow-spread oceanic lithosphere: Results from IODP Site U1309 (Atlantis Massif, 30 $\mathrm{N}$ Mid-Atlantic-Ridge). Earth and Planetary Science Letters 279, 110-122.

Hayman, N.W., Grindlay, N.R., Perfit, M.R., Mann, P., Leroy, S., De LÉPinay, B.M. (2011) Oceanic core complex development at the ultraslow spreading Mid-Cayman Spreading Center. Geochemistry Geophysics Geosystems 12(3), 1525-2027.

JAmes, R.H., Elderfield, H., PALMER, M.R. (1995) The chemistry of hydrothermal fluids from the Broken Spur site, 29 N Mid-Atlantic Ridge. Geochimica et Cosmochimica Acta 59, 651-659.

JANECKY, D.R., SEYFRIED, W.E. (1986) Hydrothermal serpentinization of peridotite within the oceanic crust: Experimental investigations of mineralogy and major element chemistry. Geochimica et Cosmochimica Acta 50, 1357-1378.

Johnson, J., OElKers, E., Helgesen, H. (1992) SUPCRT92: a software package for calculating the standard molal thermodynamic properties of minerals, gases, aqueous species, and reactions from 1 to 5000 bar and 0 to $1000^{\circ} \mathrm{C}$. Computational Geoscience 18, 899-947.

Johnston, D.T. (2011) Multiple sulfur isotopes and the evolution of Earth's surface sulfur cycle. Earth Science Reviews 106, 161-183.

KELLEY, D.S. (1996) Methane-rich fluids in the oceanic crust. Journal of Geophysical Research 101, 2943-2962.

Kelley, D.S., FrÜH-Green, G.L. (1999) Abiogenic methane in deep-seated mid-ocean ridge environments: Insights from stable isotope analyses. Journal of Geophysical Research 104, 10439-10460.

Kelley, D.S., Fruh-Green, G.L. (2001) Volatile lines of descent in submarine plutonic environments: insights from stable isotope and fluid inclusion analyses. Geochimica et Cosmochimica Acta 65, 3325-3346.

Kelley, D., KARSOn, J., BlackMAN, D. (2001) An off-axis hydrothermal vent field near the Mid-Atlantic Ridge at $30^{\circ}$ N. Nature 412, 145-149.

Kelley, D.S., Baross, J.A., Delaney, J.R. (2002) Volcanoes, fluids, and life at Mid-Ocean Ridge Spreading Centers. Annual Review of Earth and Planetary Sciences 30, 385-491. 
Klein, F., BACH, W., McCollom, T.M. (2013) Compositional controls on hydrogen generation during serpentinization of ultramafic rocks. Lithos 178, 55-69.

KLÜGEL, A., KLEIN, F. (2006) Complex magma storage and ascent at embryonic submarine volcanoes from the Madeira Archipelago. Geology 34, 337.

Lister, C. (1974) On the penetration of water into hot rock. Geophs. J. R. Astron. Soc. 39, 465509.

Lister, C. (1982) "Active" and "passive" hydrothermal systems in the oceanic crust: Predicted physical conditions, in: Fanning, K., Manheim, F. (Eds.), The Dynamic Enviornment of the Ocean Floor. D.C. Heath, Lexington, MA, pp. 441-459.

LOwell, R.P. (2013) Hydrothermal Circulation at Slow Spreading Ridges: Analysis of Heat Sources and Heat Transfer Processes, Diversity Of Hydrothermal Systems On Slow Spreading Ocean Ridges. American Geophysical Union, pp. 11-26.

Martin, W., Baross, J., Kelley, D., Russell, M.J. (2008) Hydrothermal vents and the origin of life. Nature Reviews Microbiology 6, 805-814.

McCaig, A.M., Cliff, R.A., Escartin, J., Fallick, A.E., MacLeOD, C.J. (2007) Oceanic detachment faults focus very large volumes of black smoker fluids. Geology 35, 935-938.

McCollom, T.M., SeEwald, J. (2001) A reassessment of the potential for reduction of dissolved $\mathrm{CO}_{2}$ to hydrocarbons during serpentinization of olivine. Geochimica et Cosmochimica Acta 65, 3769-3778.

MCColLom, T.M. (2003) Experimental constraints on the hydrothermal reactivity of organic acids and acid anions: I. Formic acid and formate. Geochimica et Cosmochimica Acta 67, 3625-3644.

MCCollom, T.M. (2007) Geochemical Constraints on Sources of Metabolic Energy for Chemolithoautotrophy in Ultramafic-Hosted Deep-Sea Hydrothermal Systems. Astrobiology 7, 933-950.

McCollom, T.M., SeEwald, J.S. (2007) Abiotic synthesis of organic compounds in deep-sea hydrothermal environments. Chem. Rev. 107, 382-401.

MCCOLlOM, T.M., BACH, W. (2009) Thermodynamic constraints on hydrogen generation during serpentinization of ultramafic rocks. Geochimica et Cosmochimica Acta 73, 856-875. 
MotTL, M.J., Holland, H.D. (1978) Chemical exchange during hydrothermal alteration of basalt by seawater - I. Experimental results for major and minor components of seawater. Geochimica et Cosmochimica Acta 42, 1103-1115.

Nakamura, K., Morishita, T., Bach, W., Klein, F., Hara, K., Okino, K., TaKai, K., KumagaI, H. (2009) Serpentinized troctolites exposed near the Kairei Hydrothermal Field, Central Indian Ridge: Insights into the origin of the Kairei hydrothermal fluid supporting a unique microbial ecosystem. Earth and Planetary Science Letters 280, 128136.

Nisbet, E.G., SLEEP, N.H. (2001) The habitat and nature of early life. Nature 409, 1083-1091.

Онмото, H., LASAGA, A. (1982) Kinetics of reactions between aqueous sulfates and sulfides in hydrothermal systems. Geochimica et Cosmochimica Acta 46, 1727-1745.

Ono, S., Shanks, W.C., III, Rouxel, O., Rumble, D. (2007) S-33 constraints on the seawater sulfate contribution in modern seafloor hydrothermal vent sulfides. Geochimica et Cosmochimica Acta 71, 1170-1182.

Ono, S., Wing, B., Johnston, D., Farquhar, J., Rumble, D. (2006) Mass-dependent fractionation of quadruple stable sulfur isotope system as a new tracer of sulfur biogeochemical cycles. Geochimica et Cosmochimica Acta 70, 2238-2252.

Oremland, R.S., Des Marais, D.J. (1983) Distribution, abundance and carbon isotopic composition of gaseous hydrocarbons in Big Soda Lake, Nevada: an alkaline, meromictic lake. Geochimica et Cosmochimica Acta 47, 2107-2114.

Pedersen, R.B., Rapp, H.T., Thorseth, I.H., Lilley, M.D., Barriga, F.J.A.S., Baumberger, T., Flesland, K., Fonseca, R., FrÜh-Green, G., Jorgensen, S.L. (2010) Discovery of a black smoker vent field and vent fauna at the Arctic Mid-Ocean Ridge. Nature Communications 1, 126-126.

Proskurowski, G., Lilley, M., Seewald, J., Fruh-Green, G., Olson, E., Lupton, J., Sylva, S., Kelley, D. (2008) Abiogenic hydrocarbon production at Lost City hydrothermal field. Science 319, 604.

Ravizza, G., Blusztajn, J., Von Damm, K., Bray, A., Bach, W., Hart, S. (2001) Sr isotope variations in vent fluids from $9^{\circ} 46^{\prime}-9^{\circ} 54^{\prime} \mathrm{N}$ East Pacific Rise: evidence of a non-zeroMg fluid component. Geochimica et Cosmochimica Acta 65, 729-739. 
Rees, C., Jenkins, W., Monster, J. (1978) The sulphur isotopic composition of ocean water sulphate. Geochimica et Cosmochimica Acta 42, 377-381.

ReEves, E.P., McDermott, J.M., Seewald, J. (2014) Methanethiol production in mid-ocean ridge hydrothermal fluids. Proceedings of the National Academy of Sciences 111(15), 5474-5479.

Reeves, E.P., Seewald, J.S., Saccocia, P., Bach, W., Craddock, P.R., Shanks III, W.C., Sylva, S.P., WAlsh, E., Pichler, T., Rosner, M. (2011) Geochemistry of hydrothermal fluids from the PACMANUS, Northeast Pual and Vienna Woods hydrothermal fields, Manus Basin, Papua New Guinea. Geochimica et Cosmochimica Acta 75, 1088-1123.

ReEves, E.P., SEewAld, J.S., Sylva, S.P. (2012) Hydrogen isotope exchange between n-alkanes and water under hydrothermal conditions. Geochimica et Cosmochimica Acta 77, 582599.

Rosencrantz, E., Ross, M., Sclater, J. (1988) Age and Spreading History of the Cayman Trough as Determined From Depth, Heat-Flow, and Magnetic-Anomalies. Journal of Geophysical Research-Solid Earth and Planets 93, 2141-2157.

Russell, M.J., Hall, A.J., Martin, W. (2010) Serpentinization as a source of energy at the origin of life. Geobiology 8, 355-371.

SAKai, H., MARAis, D., UedA, A., MoOre, J. (1984) Concentrations and isotope ratios of carbon, nitrogen and sulfur in ocean-floor basalts. Geochimica et Cosmochimica Acta 48, 24332441.

Seewald, J.S., Doherty, K.W., Hammar, T.R., Liberatore, S.P. (2002) A new gas-tight isobaric sampler for hydrothermal fluids. Deep Sea Research Part I: Oceanographic Research Papers 49, 189-196.

Seewald, J.S., Zolotov, M., McCollom, T. (2006) Experimental investigation of single carbon compounds under hydrothermal conditions. Geochimica et Cosmochimica Acta 70, 446-460.

SEYFRIED JR, W.E., DibBLe, J., (1980) Seawater-peridotite interaction at $300^{\circ} \mathrm{C}$ and 500 bars: implications for the origin of oceanic serpentinites. Geochimica et Cosmochimica Acta 44, 309-321. 
SEYFrIED JR, W.E., BiSCHOFF, J. (1981) Experimental seawater-basalt interaction at $300^{\circ} \mathrm{C}, 500$ bars, chemical exchange, secondary mineral formation and implications for the transport of heavy metals. Geochimica et Cosmochimica Acta 45, 135-147.

SEYfried JR, W.E., JANECKY, D.R., MotTL, M.J. (1984) Alteration of the oceanic crust: implications for geochemical cycles of lithium and boron. Geochimica et Cosmochimica Acta 48, 557-569.

SEYFRIED JR, W.E. (1987) Experimental and theoretical constraints on hydrothermal alteration processes at mid-ocean ridges. Annual Review of Earth and Planetary Sciences 15, 317336.

SEYFried JR, W.E., Ding, K., Berndt, M.E. (1991) Phase equilibria constraints on the chemistry of hot spring fluids at mid-ocean ridges. Geochimica et Cosmochimica Acta 55, 35593580 .

Seyfried JR, W.E., Pester, N.J., Ding, K., Rough, M. (2011) Vent fluid chemistry of the Rainbow hydrothermal system $\left(36^{\circ} \mathrm{N}, \mathrm{MAR}\right)$ : Phase equilibria and in situ $\mathrm{pH}$ controls on subseafloor alteration processes. Geochimica et Cosmochimica Acta 75, 1574-1593.

Seyfried JR, W.E., Foustoukos, D.I., Fu, Q. (2007) Redox evolution and mass transfer during serpentinization: An experimental and theoretical study at $200^{\circ} \mathrm{C}, 500$ bar with implications for ultramafic-hosted hydrothermal systems at Mid-Ocean Ridges. Geochimica et Cosmochimica Acta 71, 3872-3886.

SHANKS III, W.C. (2001) Stable isotopes in seafloor hydrothermal systems: vent fluids, hydrothermal deposits, hydrothermal alteration, and microbial processes. Reviews in Mineralogy and Geochemistry 43, 468-525.

SHANKS III, W.C., SEYFRIED JR, W. (1987) Stable isotope studies of vent fluids and chimney minerals, southern Juan de Fuca Ridge: Sodium metasomatism and seawater sulfate reduction. Journal of Geophysical Research 92, 11387-11399.

SHOCK, E.L. (1990) Geochemical constraints on the origin of organic compounds in hydrothermal systems. Origins of Life and Evolution of Biospheres 20, 331-367.

SHOCK, E.L. (1992) Chemical Environments of Submarine Hydrothermal Systems, in: Holm, N.G. (Ed.), Marine Hydrothermal Systems and the Origin of Life. Springer Netherlands, pp. 67-107. 
SHOCK, E.L., Schulte, M.D. (1998) Organic synthesis during fluid mixing in hydrothermal systems. Journal of Geophysical Research: Planets 103, 28513-28527.

SinHA, M.C., EvANS, R.L., 2004. Geophysical constraints upon the thermal regime of the ocean crust, Mid-Ocean Ridges: Hydrothermal Interactions Between the Lithosphere and Oceans. AGU, Washington, DC, pp. 19-62.

StrouP, J., FOX, P. (1981) Geologic Investigations in the Cayman Trough: Evidence for Thin Oceanic-Crust Along the Mid-Cayman Rise. Journal of Geology 89, 395-420.

Tao, C., Lin, J., Guo, S., Chen, Y.J., Wu, G., Han, X., German, C.R., Yoerger, D.R., Zhou, N., Li, H., SU, X., ZHU, J., AND THE DY115-19 (Legs 1-2) AND DY115-20 (LEGS 4-7) SCIENCE PARTIES (2011) First active hydrothermal vents on an ultraslow-spreading center: Southwest Indian Ridge. Geology 40, 47-50.

Trefry, J., Butterfield, D., Metz, S., Massoth, G., Trocine, R., Feely, R. (1994) Trace metals in hydrothermal solutions from Cleft segment on the southern Juan de Fuca Ridge. Journal of Geophysical Research 99, 4925-4935.

Tucholke, B.E., Lin, J., KleinRock, M.C. (1998) Megamullions and mullion structure defining oceanic metamorphic core complexes on the Mid-Atlantic Ridge. Journal of Geophysical Research: Solid Earth (1978-2012) 103, 9857-9866.

VANKO, D.A. (1988) Temperature, pressure, and composition of hydrothermal fluids, with their bearing on the magnitude of tectonic uplift at mid-ocean ridges, inferred from fluid inclusions in oceanic layer 3 rocks. Journal of Geophysical Research: Solid Earth (19782012) 93, 4595-4611.

Von Damm, K.L., Edmond, J.M., Grant, B., Walden, B., Weiss, R.F. (1985) Chemistry of submarine hydrothermal solutions at $21^{\circ} \mathrm{N}$, East Pacific Rise. Geochimica et Cosmochimica Acta 49, 2197-2220.

Von DAmM, K.L., BISCHOFf, J., RosenbAuER, R. (1991) Quartz solubility in hydrothermal seawater: an experimental study and equation describing quartz solubility for up to $0.5 \mathrm{M}$ $\mathrm{NaCl}$ solutions. American Journal of Science 291, 977-1007.

Von Damm, K.L., Bray, A., Buttermore, L., Oosting, S. (1998) The geochemical controls on vent fluids from the Lucky Strike vent field, Mid-Atlantic Ridge. Earth and Planetary Science Letters 160, 521-536. 
VON DAMM, K.L. (2000) Chemistry of hydrothermal vent fluids from 9-10² N, East Pacific Rise: “Time zero,” the immediate posteruptive period. J. Geophys. Res 105, 11203-11222.

Voss, B.M., Peucker-Ehrenbrink, B., Eglinton, T.I., Fiske, G., WAng, Z.A., Hoering, K.A., Montluçon, D.B., LeCroy, C., Pal, S., Marsh, S., Gillies, S.L., JanmaAt, A., Bennett, M., Downey, B., Fanslau, J., Fraser, H., Macklam-Harron, G., Martinec, M., Wiebe, B. (2014) Tracing river chemistry in space and time: Dissolved inorganic constituents of the Fraser River, Canada. Geochimica et Cosmochimica Acta 124, 283-308.

Welhan, J. (1988) Origins of Methane in Hydrothermal Systems. Chemical Geology 71, 183198.

Wetzel, L.R., SHOcK, E.L. (2000) Distinguishing ultramafic-from basalt-hosted submarine hydrothermal systems by comparing calculated vent fluid compositions. Journal of Geophysical Research 105, 8319-8340.

White, S.M., Stroup, J.B. (1979) Distribution of Rock Types in the Mid-Cayman Rise, Caribbean Sea, as Evidence for Conjugate Normal Faulting in Slowly Spreading Ridges. Geology 7, 32-36.

Wolery, T.J. (1992) EQ3NR, A Computer Program for Geochemical Aqueous SpeciationSolubility Calculations: Theoretical Manual, User's Guide, and Related Documentation (Version 7.0). Lawrence Livermore National Lab.

Wolery, T.J., DAVEler, S.A. (1992) EQ6, A Computer Program for Reaction Path Modeling of Aqueous Geochemical Systems: Theoretical Manual, User's Guide, and Related Documents. Lawrence Livermore National Lab.

Wolery, T.J., Jove-Colon, C.F. (2004) Qualification of Thermodynamic Data for Geochemical Modeling of Mineral-Water Interactions in Dilute Systems. Scandia National Laboratories, Las Vegas, Nevada.

WoOdRufF, L., SHANKS III, W.C. (1988) Sulfur isotope study of chimney minerals and vent fluids from 21 N, East Pacific Rise: Hydrothermal sulfur sources and disequilibrium sulfate reduction. Journal of Geophysical Research 93, 4562-4572. 


\title{
Chapter 4
}

\section{Geochemistry of Deep-Sea Hydrothermal Fluids from the Piccard}

\author{
Vent Field, Mid-Cayman Rise, Caribbean Sea
}

\begin{abstract}
Hosted in basaltic substrate on the ultra-slow Mid-Cayman Rise, the world's deepest spreading center, the Piccard hydrothermal field is the deepest currently known seafloor hotsprings (4957-4987 m). To investigate the role of substrate composition and deep fluid circulation conditions on fluid chemistry, the abundance and isotopic composition of organic, inorganic, and dissolved volatile species in vent fluids at Piccard were examined in samples collected in 2012 and 2013. Fluids vent at a maximum temperature of $398^{\circ} \mathrm{C}$ at the seafloor, however several lines of evidence derived from inorganic fluid chemistry $\left(\mathrm{Cl}, \mathrm{SiO}_{2}\right.$, and $\left.\mathrm{Ca}\right)$ support fluid formation at much higher temperatures in the subsurface, potentially in excess of $500^{\circ} \mathrm{C}$. These high temperatures are attainable due to the great depth of the system. Phase equilibrium modeling carried out as part of this study indicates that reaction at these high temperatures explains the extremely high source fluid $\mathrm{H}_{2}$ contents measured at Piccard (18.9 to 20.7 mM). Piccard fluid $\mathrm{H}_{2}$ abundances are even higher than those observed in ultramafic-hosted
\end{abstract}


systems, such as the ultramafic-influenced Rainbow vent field $(16 \mathrm{mM})$ and the Von Damm hydrothermal field reported in this study (CHAPTER 2, CHAPTER 3).

Diffuse fluids sampled at Piccard range in temperature from 45 to $149^{\circ} \mathrm{C}$, spanning the abiotic-biotic temperature transition which has not been well-studied in seafloor hydrothermal systems. As such, the Piccard system provides an ideal natural laboratory for investigating organic and inorganic subsurface mixing reactions. Here, abiotic reactions in hydrothermal mixing zones at Piccard are examined through consideration of enrichments and depletions in mixed fluid organic and inorganic fluid geochemistry. Magmatic and thermogenic carbon sources in the high temperature black smoker vents are described, as are the origin and chemical controls on the abundant organic species in lower temperature diffuse fluids, which are replete with formate species generated by abiotic $\mathrm{CO}_{2}$ reduction as well as pyrolytic $\mathrm{CH}_{4}$ and $\mathrm{C}_{2+}$ hydrocarbons.

\section{INTRODUCTION}

Hosted in the basaltic neovolcanic zone at $\sim 5000 \mathrm{~m}$ depth on the $110 \mathrm{~km}$ long ultra-slow spreading Mid-Cayman Rise (MCR), the Piccard vent field is the world's deepest mid-ocean ridge hydrothermal vent system (BEAULIEU et al., 2013). The extreme depth of the MCR has the potential to broaden our current understanding of deep-sea vent fluid geochemistry because the effects of pressure create an environment that can support higher temperatures of fluid/rock reaction in the subsurface and at the seafloor. The maximum temperature of a fluid is influenced by pressure-dependent properties, including buoyancy and density, and may be limited by the two-phase boundary of seawater. The hottest vent fluids previously measured at the seafloor were actively phase separating at $407^{\circ} \mathrm{C}$ and $2990 \mathrm{~m}$ depth - conditions consistent with the two- 
phase boundary of seawater - at the basalt-hosted Turtle Pits field on the Southern Mid-Atlantic Ridge (MAR) (KoschINSKY et al., 2008). Due to greater depths at Piccard, the two-phase boundary at the seafloor occurs at $483^{\circ} \mathrm{C}$ (BISCHOFF and RosenBAUER, 1988). Therefore, the possiblity exists for circulating fluids to attain extremely high temperatures in the subsurface. Presented here is a detailed chemical and isotopic characterization of hydrothermal fluids collected in 2012 and 2013 at the Piccard hydrothermal field that examine the effects of high pressure and temperature on water-rock reaction conditions.

In CHAPTERS 2 and 3, the origins of organic species in the ultramafic-influenced Von Damm system were discussed. Here, carbon sources in the high temperature $\leq 398^{\circ} \mathrm{C}$ basalthosted 'black smoker' Piccard vents are examined, as are the origin and chemical controls on organic species in related lower temperature mixed 'diffuse' fluids. Diffuse fluids sampled at Piccard range from 45 to $149^{\circ} \mathrm{C}$, and therefore span the abiotic-biotic temperature transition, which has not been well-studied in seafloor hydrothermal systems. In several studies examining the geochemistry of hydrothermal vent fluids in mixing zone temperature regimes cooler than the current $122^{\circ} \mathrm{C}$ limit for life (TAKAI et al., 2008), depletions in $\mathrm{H}_{2}$ and enrichments in $\mathrm{CH}_{4}$ have been attributed to microbial production via active methanogenesis (VON DAMM and LILLEY, 2004; WANKEL et al., 2011). Here mixed fluids at Piccard present the opportunity to trace fluid $\mathrm{H}_{2}$ contents via a series of abiotic reactions. Multiple sources of organic compounds are identified in the Piccard fluids, ranging from abiotic mantle-derived hydrocarbons in the hightemperature black smoker fluids, to likely abiotic generation of formate species $(\Sigma \mathrm{HCOOH}=$ $\left.\mathrm{HCOOH}+\mathrm{HCOO}^{-}\right)$and pyrolytic hydrocarbon inputs within mixed fluids. 


\section{GEOLOGIC SETTING AND DESCRIPTION OF SAMPLING SITES}

The Mid-Cayman Rise is an ultra-slow spreading ridge (15-17 mm/yr full rate) (ROSENCRANTZ et al., 1988) located in the Cayman Trough and surrounded by the North American plate to the north, the Caribbean plate to the south, and the Gonave microplate to the east (HAYMAn et al., 2011). Despite the proximity of continental and arc crust, there is no evidence for a subducted slab component in Cayman Trough basalts. The composition of midocean ridge basalts from the MCR is a fairly homogenous and well-known basaltic endmember that is moderately evolved, and generated from low melt extent in a relatively cold mantle (ELTHON et al., 1995; KLEIN and LANGMUIR, 1987).

The Piccard hydrothermal field is located on the eastern flank of a $12 \mathrm{~km}$ long volcanic ridge that runs from $18^{\circ} 27^{\prime} \mathrm{N}$ to $18^{\circ} 34^{\prime} \mathrm{N}$ through the axial trough of the MCR (KINSEY and German, 2013) (Fig. 1A). The site was discovered in 2009-2010 through a combination of Nereus AUV and CTD plume surveys (GERMAN et al., 2010) followed by further surveys with the AUTOSUB Autonomous Underwater Vehicle and HYBIS (CONNELLY et al., 2012). Detailed mapping of the site was conducted by ROV Jason in 2012 (KINSEY and GERMAN, 2013) which revealed that the full extent of the Piccard hydrothermal field comprises 7 polymetallic sulfide mounds, 4 inactive and 3 active (New Fig.1B). These mounds, in turn, are surrounded by unsedimented pillow basalts and sheet flows with low sediment cover. Surficial seafloor geology is indicative of a classic axial, neovolcanic hydrothermal system that is hosted in basaltic substrate.

Within the larger Piccard field, hydrothermal fluids were collected from four different regions of venting, including the Beebe Vents, Beebe Woods, Beebe Sea, and Hot Chimlet areas (Fig. 1C). High temperature venting occurs at Beebe Vents from a linear array of five slender 2 
to $3 \mathrm{~m}$ tall focused black smoker chimneys at $4957 \mathrm{~m}$ atop a $40 \mathrm{~m}$ diameter mound $\left(18^{\circ} 32.798^{\prime} \mathrm{N}, 81^{\circ} 43.092^{\prime} \mathrm{W}\right)$. High temperature fluids also vent from several orifices at Beebe Woods, a cluster of $\sim 10$ taller, wider ( $7 \mathrm{~m}$ tall by 0.2 to $0.5 \mathrm{~m}$ wide) beehive diffuser chimneys at $4962 \mathrm{~m}$ depth on a separate $40 \mathrm{~m}$ diameter mound situated $\sim 100 \mathrm{~m}$ south of Beebe Vents. Although not sampled for this study, a single black smoker chimney, termed Lung Snack, also vents adjacent to the Beebe Woods vent cluster (REveILlaud et al., in prep.). A third discrete mound, Beebe Sea, located to the SE of Beebe Vents and NE of Beebe Woods, is $90 \mathrm{~m}$ in diameter and emits clear low-temperature diffuse fluids. The presence of abundant extinct sulfide chimneys indicates the past occurrence of high temperature venting at this site. Three sets of fluids were collected from the Beebe Sea mound in an area termed Shrimp Gulley due to the presence of abundant swarming rimicaris shrimp at this location, associated with active clear diffuse fluid flow from a cleft incised into the northern flank of the mound. Low-temperature diffuse fluids were also sampled at a fourth discrete vent site, Hot Chimlet, located $60 \mathrm{~m}$ north of Beebe Vents, on the northern flank of the Beebe Vents mound at a depth of $4987 \mathrm{~m}$.

Ultra-slow spreading ridges are regions of anomalously thin ocean crust which provide potentially important constraint on the maximum depth of hydrothermal fluid circulation, assuming fluids can only circulate through brittle lithosphere. Seismic determinations of Moho depth along several profiles in the Cayman Trough yield crustal thicknesses of 4.2 to $4.6 \mathrm{~km}$ (EWING et al., 1960; TEN BRINK et al., 2002) that are in good agreement with geochemical inferences for the degree of mantle melting and igneous rock production which predict crustal thicknesses of 1.9 to $4.9 \mathrm{~km}$ (WHITE et al., 2001). A crustal thicknesses of this magnitude is significantly thinner than the relatively uniform crustal thickness of $6.3 \pm 0.9 \mathrm{~km}$ at ridges with full spreading rates of $>20 \mathrm{~mm} / \mathrm{yr}$ (Bown and WHITE, 1994; WHITE et al., 1992). 


\section{Methods}

\subsection{Sample Collection}

Fluid samples were collected using $150 \mathrm{~mL}$ titanium isobaric gas-tight (IGT) samplers (SEEWALD et al., 2002) deployed by the ROV Jason II during R/V Atlantis cruise AT18-16 in January 2012 and by the HROV Nereus during R/V Falkor cruise FK008 in June 2013. Fluid temperatures were monitored continuously with thermocouples aligned with sampler inlet snorkel tips. Thermocouples were calibrated with a National Institute of Standards and Technology (NIST) temperature calibrator, and the maximum measured temperature for each sample is reported $\left( \pm 2^{\circ} \mathrm{C}\right)($ Table 1$)$. In most cases, replicate samples were taken at a single orifice, although in one instance (Shrimp Gulley \#3, 2013), only one fluid was recovered. Due to variability in dive duration, 5-20 hours elapsed between collection on the seafloor and sample processing on the ship.

During sample processing, aliquots were extracted for shipboard analysis of $\mathrm{pH}\left(25^{\circ} \mathrm{C}\right)$ and total dissolved sulfide $\left(\Sigma \mathrm{H}_{2} \mathrm{~S}=\mathrm{H}_{2} \mathrm{~S}+\mathrm{HS}^{-}+\mathrm{S}^{2-}\right), \mathrm{CH}_{4}$, and $\mathrm{H}_{2}$, and shore-based analysis of other major species $\left(\mathrm{Na}, \mathrm{Cl}, \mathrm{Mg}, \mathrm{Ca}, \mathrm{K}, \mathrm{SiO}_{2}, \mathrm{SO}_{4}\right)$, minor and trace inorganic species $(\mathrm{Br}, \mathrm{Li}$, $\mathrm{Sr}, \mathrm{Rb}, \mathrm{Fe}, \mathrm{Mn}, \mathrm{Zn}, \mathrm{Cu}, \mathrm{Pb}, \mathrm{Co}, \mathrm{Cd}, \mathrm{Cr}, \mathrm{Ni}, \mathrm{Cs}, \mathrm{Tl}$ ) and volatiles including total inorganic carbon $\left(\Sigma \mathrm{CO}_{2}=\mathrm{CO}_{2}+\mathrm{HCO}_{3}{ }^{-}+\mathrm{CO}_{3}{ }^{2-}\right)$, and trace hydrocarbons $\left(\mathrm{C}_{2} \mathrm{H}_{6}, \mathrm{C}_{3} \mathrm{H}_{8}, \mathrm{n}-\mathrm{C}_{4} \mathrm{H}_{10}, \mathrm{i}-\mathrm{C}_{4} \mathrm{H}_{10}\right)$. Dissolved $\Sigma \mathrm{H}_{2} \mathrm{~S}$ was precipitated as $\mathrm{Ag}_{2} \mathrm{~S}$ in $5 \mathrm{wt} \% \mathrm{AgNO}_{3}$ and stored for later gravimetric abundance determination (REEVES et al., 2011). Fluid aliquots for major, minor, and trace species were transferred to separate acid-washed high-density polyethylene (HDPE) Nalgene ${ }^{\mathrm{TM}}$ bottles. Aliquots for transition metals and $\mathrm{SiO}_{2}$ analysis were immediately acidified to $\mathrm{pH}<2$ with concentrated Optima ${ }^{\mathrm{TM}} \mathrm{HCl}$, while major and minor species and $\mathrm{SO}_{4}$ aliquots were not acidified. Aliquots were collected for $\mathrm{SO}_{4}$ by sparging untreated fluid with $\mathrm{N}_{2}(\sim 20 \mathrm{~min})$ to 
remove $\mathrm{H}_{2} \mathrm{~S}$ that may otherwise oxidize during storage and elevate measured $\mathrm{SO}_{4}$ abundances. Aliquots for later shore-based $\Sigma \mathrm{CO}_{2}$ abundance and $\mathrm{CH}_{4}$ and $\Sigma \mathrm{CO}_{2}$ stable carbon and radiocarbon isotope analysis were transferred to evacuated serum vials sealed with $\mathrm{NaOH}$-boiled butyl rubber stoppers (OREMLAND and DES MARAIS, 1983). Aliquots for trace hydrocarbons were transferred into evacuated glass tubes fitted with Teflon, brass, and stainless gas-tight valves. Fluid samples (5 $\mathrm{g}$ fluid) for He isotope analysis were transferred directly from the IGTs under vacuum into evacuated aluminosilicate glass break-seal tubes and flamed sealed.

Following fluid sample processing, the 'dregs' fraction that contains any precipitates that may have formed as a result of cooling or mixing within the sampler was collected at sea on 0.22 $\mu \mathrm{m}$ pore size, $44 \mathrm{~mm}$ diameter Nylon filters, by rinsing the sample chamber with Milli-Q water and high-purity acetone, dried, and stored. Small amounts of precipitates formed during storage of acidified metals aliquots, thus the 'bottle filter fraction' was separated from the aqueous sample in the laboratory at WHOI by filtration using acid-washed HDPE syringes equipped with removable $0.22 \mu \mathrm{m}$ pore size, $22 \mathrm{~mm}$ diameter Nucleopore $^{\mathrm{TM}}$ filters. The bottle filter fraction filters were stored in acid-washed $30 \mathrm{~mL}$ Teflon Savillex ${ }^{\mathrm{TM}}$ vials prior to digestion. In the shorebased lab at WHOI, dregs fraction particles and filters were quantitatively transferred to $30 \mathrm{~mL}$ Teflon Savillex ${ }^{\mathrm{TM}}$ vials by rinsing with Optima ${ }^{\mathrm{TM}}$ methanol, and evaporating to dryness in a trace-metal clean hood. Both the bottle filter and dregs fraction particles were separated from filters by soaking in $5 \mathrm{~mL}$ of reverse aqua regia $\left(1: 3 \mathrm{HCl}: \mathrm{HNO}_{3}\right)$ in $30 \mathrm{~mL}^{\text {Savillex }}{ }^{\mathrm{TM}}$ vials overnight. To digest particulates, the uncovered vials were heated at $70^{\circ} \mathrm{C}$ until the particles dissolved, and the aqua regia was evaporated to near dryness. The digestion and dry down process was repeated three times to ensure complete digestion. Digested residues were then brought back up in 5\% Optima ${ }^{\mathrm{TM}} \mathrm{HNO}_{3}$ prior to analysis. 


\subsection{Analytical methods}

\subsection{1 $\mathrm{pH}$ and volatiles}

Species abundances determined at sea are reported in units of $\mu \mathrm{mol} / \mathrm{L}$ or $\mathrm{mmol} / \mathrm{L}$ fluid, while those determined on shore are reported in units of nmol/ $\mathrm{kg}, \mu \mathrm{mol} / \mathrm{kg}$ or $\mathrm{mmol} / \mathrm{kg}$ (Tables 1, 2, and 3). Immediately after withdrawing a fluid aliquot from the IGT sampler, $\mathrm{pH}\left(25^{\circ} \mathrm{C}, 1\right.$ atm) was measured onboard ship by potentiometry using a $\mathrm{Ag} / \mathrm{AgCl}$ combination reference electrode. $\mathrm{H}_{2}$ and $\mathrm{CH}_{4}$ were analyzed shipboard by gas chromatography (GC) using a $5 \AA$ molecular sieve packed column and thermal conductivity detection after headspace extraction in a gastight syringe. Dissolved $\Sigma \mathrm{H}_{2} \mathrm{~S}$ was determined shipboard by iodometric starch titration of an aliquot drawn into a gastight syringe (AMERICAN PUBlic HeAlth AssocATION, 1980) as described in VON DAMM (2000). In the shore-based laboratory at WHOI, $\mathrm{Ag}_{2} \mathrm{~S}$ was filtered onto $0.22 \mu \mathrm{m}$ pore size, $25 \mathrm{~mm}$ diameter Nylon filters, weighed to determine $\Sigma \mathrm{H}_{2} \mathrm{~S}$ concentrations, and stored in glass vials for multiple sulfur isotopic analysis. Reported $\mathrm{H}_{2} \mathrm{~S}$ abundances are an average of results from the titration and gravimetric methods for 2012 samples and titration results only for 2013 samples. At WHOI, $\Sigma \mathrm{CO}_{2}$ was determined for the 2012 samples following sample acidification with $25 \mathrm{wt} . \% \mathrm{H}_{3} \mathrm{PO}_{4}$ by headspace injection into a GC equipped with a Porapak $^{\mathrm{TM}} \mathrm{Q}$ packed column and thermal conductivity detection. The results are corrected to account for $\Sigma \mathrm{CO}_{2}$ partitioning between the fluid and headspace within each serum vial as in REEVES et al. (2011). Samples from 2013 were not processed for $\Sigma \mathrm{CO}_{2}$ abundance due to a contamination issue. Trace $\mathrm{C}_{2} \mathrm{H}_{6}, \mathrm{C}_{3} \mathrm{H}_{8}, \mathrm{n}-\mathrm{C}_{4} \mathrm{H}_{10}$, and $\mathrm{i}-\mathrm{C}_{4} \mathrm{H}_{10}$ abundances were determined at WHOI via a purge-and-trap device interfaced to a GC equipped with a Porapak $^{\mathrm{TM}} \mathrm{Q}$ packed column and flame ionization detection (CRUSE and SEEWALD, 2006). The analytical uncertainty 


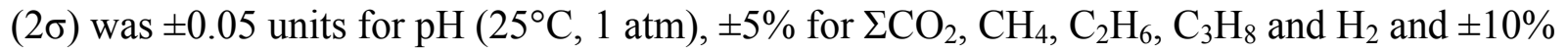
for $\mathrm{n}-\mathrm{C}_{4} \mathrm{H}_{10}, \mathrm{i}-\mathrm{C}_{4} \mathrm{H}_{10}$, and $\Sigma \mathrm{H}_{2} \mathrm{~S}$.

\subsubsection{Major, minor, and trace element abundances}

Major and trace element concentrations were determined at WHOI by ion chromatography $\left(\mathrm{Na}, \mathrm{Cl}, \mathrm{Ca}, \mathrm{K}, \mathrm{Li}, \mathrm{SO}_{4}, \mathrm{Br}\right)$ and by inductively coupled plasma mass spectrometry (ICP-MS) (Mg, $\left.\mathrm{SiO}_{2}, \mathrm{Sr}, \mathrm{Rb}\right)$. During IC and ICP-MS analyses, samples were bracketed with NIST-traceable external standards. For major and minor elements which do not precipitate, only the aqueous fraction was analyzed. Transition metals readily precipitate upon cooling in the samplers and storage bottles, and the data in Table 5 represent reconstituted fluids calculated from the 'aqueous,' 'bottle-filter' and 'dregs' fraction analyses. The analytical uncertainty $(2 \sigma)$ was $\pm 3 \%$ for $\mathrm{Na}, \mathrm{Cl}, \mathrm{Ca}, \mathrm{K}, \mathrm{SO}_{4}, \mathrm{Mg}, \mathrm{SiO}_{2}$ and $\mathrm{Sr} ; \pm 5 \%$ for $\mathrm{Li}, \mathrm{Rb}, \mathrm{Fe}, \mathrm{Mn}, \mathrm{Zn}$, $\mathrm{Cu}, \mathrm{Al}, \mathrm{Pb}, \mathrm{Co}$ and $\mathrm{Cd}$; and $\pm 10 \%$ for $\mathrm{Br}$. For ICP-MS analysis details, including metal abundances within each fraction analyzed, see Appendix.

\subsubsection{Isotopes}

Stable $\delta^{13} \mathrm{C}$ carbon isotope analysis of $\Sigma \mathrm{CO}_{2}, \mathrm{CH}_{4}, \mathrm{C}_{2} \mathrm{H}_{6}$ and $\mathrm{C}_{3} \mathrm{H}_{8}$ was conducted at WHOI by isotope ratio monitoring-mass spectrometry using a Finnigan DeltaPlusXL mass spectrometer coupled to an Agilent $6890 \mathrm{GC}$ with an $1150^{\circ} \mathrm{C}$ combustion temperature. Analysis was performed via serum vial headspace injections for $\mathrm{\Sigma CO}_{2}$ and $\mathrm{CH}_{4}$ and a purge-and-trap device for $\mathrm{C}_{2} \mathrm{H}_{6}$ and $\mathrm{C}_{3} \mathrm{H}_{8}$. Fluids were acidified with $\mathrm{H}_{3} \mathrm{PO}_{4}$ for $\Sigma \mathrm{CO}_{2}$ analysis, and made alkaline with $\mathrm{NaOH}$ for $\mathrm{CH}_{4}, \mathrm{C}_{2} \mathrm{H}_{6}$, and $\mathrm{C}_{3} \mathrm{H}_{8}$ analysis to sequester the abundant $\Sigma \mathrm{CO}_{2}$ in solution. Due to very low $\mathrm{C}_{2} \mathrm{H}_{6}$ abundances in the high temperature fluids, several glass tube 
aliquots were combined to obtain sufficient carbon for isotopic analysis. Inorganic and organic species abundances indicate that Beebe Vents 1,3 , and 5 share one $\mathrm{C}_{2} \mathrm{H}_{6}$ endmember composition, therefore tubes from these vents were combined for $\delta^{13} \mathrm{C}_{\mathrm{C} 2 \mathrm{H} 6}$ analysis (see Table 4). Due to variable entrainment of ambient seawater that contains $2.21 \mathrm{mmol} / \mathrm{kg} \mathrm{CO}_{2}$ with a $\delta^{13} \mathrm{C}_{\mathrm{CO} 2}$ value of $1.1 \%$, reported endmember $\delta^{13} \mathrm{C}_{\mathrm{CO} 2}$ values have been calculated from measured values using isotope mass balance; this correction is very minor for high temperature vents, and larger for mixed fluids. Measured $\delta^{13} \mathrm{C}_{\mathrm{CH} 4}, \delta^{13} \mathrm{C}_{\mathrm{C} 2 \mathrm{H} 6}$, and $\delta^{13} \mathrm{C}_{\mathrm{C} 3 \mathrm{H} 8}$ values are not corrected since background seawater contains negligible quantities of these hydrocarbons.

Multiple stable sulfur isotope analysis $\left(\delta^{34} \mathrm{~S}, \delta^{33} \mathrm{~S}, \delta^{36} \mathrm{~S}\right)$ was conducted on dissolved $\mathrm{H}_{2} \mathrm{~S}$ in select 2012 samples at MIT via isotope ratio mass spectrometry following methods in ONO et al. (2006). Approximately 1 to $2 \mathrm{mg} \mathrm{Ag} 2 \mathrm{~S}$ (precipitated shipboard from fluid $\Sigma \mathrm{H}_{2} \mathrm{~S}$ ) was reacted under $\mathrm{F}_{2}$ overnight $\left(\sim 40\right.$ torr, $\left.300^{\circ} \mathrm{C}, 12+\mathrm{h}\right)$, and the product $\mathrm{SF}_{6}$ was purified by $\mathrm{GC}$ prior to isotope ratio analysis by a Thermo-Electron MAT 253.

Carbon and sulfur stable isotope data for each isotope of interest, $A$, are reported in standard delta notation $(\delta A)$ expressed as:

$$
\delta A(\%)=\left[\frac{R_{S}-R_{S T D}}{R_{S T D}}\right] \times 1000
$$

where $R_{S}$ and $R_{S T D}$ are the isotope ratios $\left({ }^{13} \mathrm{C} /{ }^{12} \mathrm{C},{ }^{33} \mathrm{~S} /{ }^{32} \mathrm{~S},{ }^{34} \mathrm{~S} /{ }^{32} \mathrm{~S},{ }^{36} \mathrm{~S} /{ }^{32} \mathrm{~S}\right)$ of the sample and the standard, respectively. Carbon and sulfur stable isotopes are reported relative to the Vienna PDB and Vienna CDT scales, respectively. The pooled standard deviation $(2 \sigma)$ for replicate samples was $\pm 0.3 \%$ for $\delta^{13} \mathrm{C}_{\mathrm{CO} 2}, \pm 0.8 \%$ for $\delta^{13} \mathrm{C}_{\mathrm{CH} 4}$, and the instrumental analytical uncertainty $(2 \sigma)$ was 
$\pm 0.4 \%$ for $\delta^{13} \mathrm{C}_{\mathrm{C} 2 \mathrm{H} 6}, \pm 0.7 \%$ for $\delta^{13} \mathrm{C}_{\mathrm{C} 3 \mathrm{H} 8}$, and $\pm 0.3 \%$ for $\delta^{34} \mathrm{~S}_{\mathrm{H} 2 \mathrm{~S}}$. Sulfur isotope data are additionally expressed in $\Delta^{33} \mathrm{~S}$ notation, defined as the deviation of the minor isotope ratio from the terrestrial fractionation reference line (GAO and THIEMENS, 1991):

$$
\Delta^{33} S=\delta^{33} S-0.515 \times \delta^{34} S
$$

Radiocarbon $\left({ }^{14} \mathrm{C}_{\mathrm{CO} 2}\right.$ and $\left.{ }^{14} \mathrm{C}_{\mathrm{CH} 4}\right)$ analysis was conducted at the WHOI National Ocean Sciences Accelerator Mass Spectrometry Facility. Results are expressed in terms of Fraction Modern $\left(\mathrm{F}_{\mathrm{m}}\right)$, representing the deviation of the sample relative to the modern NBS Oxalic Acid I standard (NIST-SRM-4990, AD 1950) (OLSSON, 1970). 'Corrected' $\Sigma \mathrm{CO}_{2}$ radiocarbon measurements (Table 4) remove the effects of entrainment of ambient seawater, with an isotopic mass balance approach that is analogous to the approach for $\delta^{13} \mathrm{C}_{\mathrm{CO} 2}$. Measured analytical uncertainties are listed in Table 4. Corrected radiocarbon $\mathrm{F}_{\mathrm{m}}$ uncertainties are conservative estimates calculated via error propagation of independent variables that accounts for the effects of $[\mathrm{Mg}]$ and $\left[\mathrm{\Sigma CO}_{2}\right]$ analytical uncertainties.

Samples were analyzed for He abundance and isotope composition in the Isotope Geochemistry Facility at WHOI (Table 5). Helium was cryogenically separated from the other noble gases (LOTT, 2001), and analyzed as described in GERMAN et al. (2010). The procedural line blank is $<1.5 \times 10^{-9} \mathrm{cc} \mathrm{STP}{ }^{4} \mathrm{He}$. One full procedural blank, which included the sea-going extraction line and full storage time in the break seal tube, was $\sim 6 \times 10^{-9} \mathrm{cc} \mathrm{STP}{ }^{4} \mathrm{He}$ (with atmospheric $\left.{ }^{3} \mathrm{He} /{ }^{4} \mathrm{He}\right)$. These blank levels are insignificant relative to the samples $(<3 \%$ in all cases), as also indicated by the mantle values for ${ }^{3} \mathrm{He} /{ }^{4} \mathrm{He}$. Uncertainties for ${ }^{4} \mathrm{He}$ abundances are approximately $\pm 5 \%$ due to splitting procedures. 
Stable strontium isotopic analysis was conducted on select samples at WHOI.

Conventional ion-exchange procedures with $\mathrm{Sr}$ spec resin were used, and ${ }^{87} \mathrm{Sr} /{ }^{86} \mathrm{Sr}$ isotope ratios were measured with a ThermoFinnigan NEPTUNE multi-collector inductively coupled plasmamass spectrometer as described in Voss et al. (2014). The internal precision for Sr isotopic measurements is $\pm 0.000010(2 \sigma)$. The external precision, after correction to values for NBS987 $(0.710240)$ is $\pm 0.000025(2 \sigma)$. Corrections for potential $\mathrm{Rb}$ and $\mathrm{Kr}$ interferences are described by JACKSON AND HART (2006).

\subsection{Calculation of Endmember Fluid Compositions}

Experimental and theoretical studies show that hydrothermal fluids undergo nearly quantitative removal of $\mathrm{Mg}$ and $\mathrm{SO}_{4}$ during fluid-rock reaction with basalt and gabbro (BISCHOFF and Dickson, 1975; Mottl and Holland, 1978; SEYFried and BischofF, 1981) and with peridotite (JANECKY and SEYFRIED, 1986; SEYFRIED et al., 2007) at high temperatures and low water/rock ratios. The snorkel and $\sim 4 \mathrm{~mL}$ dead-volume of the IGT samplers are filled with bottom seawater, thus Mg-rich seawater always comprises some fraction of a vent fluid sample. In addition, occasional accidental entrainment can occur during sample collection. Vent fluids can also undergo mixing with seawater either in the shallow seafloor subsurface or within chimney structures prior to venting at the seafloor, and in these cases elevated $\mathrm{Mg}$ contents in sampled fluids reflect real venting fluid compositions. Low-Mg fluids therefore represent the fluids containing the highest fraction of vent fluid relative to seawater. Thus, sampled fluid compositions are typically assumed to reflect two-component mixing of a zero-Mg 'endmember' fluid with bottom seawater. To correct for seawater entrainment and/or subsurface mixing, endmember abundances for each vent are calculated via least-squares regression of an individual 
conservative chemical species versus $\mathrm{Mg}$ for all samples from one vent orifice, weighted to pass through the background seawater composition and extrapolated to $0 \mathrm{mmol} / \mathrm{kg} \mathrm{Mg}$.

Due to non-conservative behavior during fluid-seawater mixing, endmember $\mathrm{pH}$ is not calculated by extrapolation, but rather the minimum measured $\mathrm{pH}\left(25^{\circ} \mathrm{C}, 1 \mathrm{~atm}\right)$, corresponding to the lowest $\mathrm{Mg}$ fluid, is reported. For some species (e.g. $\mathrm{Ca}, \mathrm{Sr}, \mathrm{SO}_{4}, \mathrm{H}_{2}$, hydrocarbons, metals) lower temperature ( 45 to $\left.149^{\circ} \mathrm{C}\right)$ 'mixed' fluids exhibit non-conservative behavior during subsurface mixing of endmember fluid with seawater. In this case, extrapolation to an endmember composition has no physical meaning. Consequently, only measured abundances are reported for non-conservative species in mixed fluids. Endmember ${ }^{86} \mathrm{Sr} /{ }^{87} \mathrm{Sr}$ values are calculated by regression to a zero molar $\mathrm{Mg} / \mathrm{Sr}$ ratio (ALBARÈDE et al., 1981).

\section{Results}

\subsection{Temperature and Mg}

Focused, low-Mg, high-temperature fluids from Beebe Vents 1, 3 and 5 displayed a narrow range of temperatures that ranged $390-398^{\circ} \mathrm{Cin} 2012$ (Table 1, Fig. 1). Nearly identical measured temperatures in 2013 indicate that temperature conditions remained constant during the elapsed 1.5 years between sampling expeditions. These temperatures are lower than the highest-yet-measured vent temperature of $407^{\circ} \mathrm{C}$ at Turtle Pits, and indicate that the Beebe Vent fluids are not actively phase separating at seafloor conditions. After removal of a beehive diffuser from its orifice, one high-temperature $\left(354^{\circ} \mathrm{C}\right)$, low- $\mathrm{Mg}(2.95 \mathrm{mmol} / \mathrm{kg})$ vent at Beebe Woods was sampled for fluids in 2012. Two low-temperature mixed fluids were sampled at Hot Chimlet in 2012 with measured temperatures of $149^{\circ} \mathrm{C}$ and $95^{\circ} \mathrm{C}$. The higher temperature site is poised just above the $122^{\circ} \mathrm{C}$ temperature limit for life (TAKAI et al., 2004). 
For mixed fluids, the close agreement in measured $\mathrm{Mg}$ abundance in replicate samples suggests that seawater mixing is occurring in the subsurface prior to venting, rather than being introduced by inadvertent entrainment during sampling. The occurrence of the latter would have resulted in highly variable $\mathrm{Mg}$ abundances. For example, measured $\mathrm{Mg}$ concentrations in replicate samples from Hot Chimlet \#1 in 2012 were 33.4 and $35.4 \mathrm{mmol} / \mathrm{kg}$, suggesting substantial subsurface mixing of a near $400^{\circ} \mathrm{C}$ high temperature endmember and $2^{\circ} \mathrm{C}$ seawater is responsible for the measured temperature of $149^{\circ} \mathrm{C}$. More extensive mixing is suggested at Hot Chimlet \#2 by the lower measured temperature of $95^{\circ} \mathrm{C}$ and higher $\mathrm{Mg}$ concentrations (Table 1). In 2013, venting fluids at the Hot Chimlet 1 site had cooled to $85^{\circ} \mathrm{C}$. Lower temperature mixed fluids ranging in temperature from $45-111^{\circ} \mathrm{C}(42.4$ to $48.9 \mathrm{mmol} / \mathrm{kg} \mathrm{Mg})$ were sampled at the Shrimp Gulley site in 2012 and 2013.

\section{$4.2 \mathrm{pH}$}

High-temperature fluids at Piccard were acidic, with $\mathrm{pH}\left(25^{\circ} \mathrm{C}, 1 \mathrm{bar}\right)$ values that ranged from 2.95 to 3.30 in low-Mg Beebe Vent and Beebe Woods fluids in 2012, and measured 3.18 in the low-Mg sample from Beebe Vent 5 in 2013. These values are similar to the average $3.3 \pm 0.5$ $\mathrm{pH}$ value of most basalt-hosted high-temperature vent fluids worldwide (GERMAN and SEYFRIED, 2014) (Table 1). Mixed fluids at Hot Chimlet and Shrimp Gulley have higher pH values overall (4.97 to 5.95). In general, fluids with higher measured $\mathrm{pH}$ value have increased $\mathrm{Mg}$ contents, consistent with the effects of increased seawater mixing. 


\subsection{Major and minor dissolved species}

Fluids at Beebe Vents 1, 3, and 5 and Beebe Woods in 2012 and 2013 are characterized by a single endmember value for each inorganic species $\left(\mathrm{Cl}, \mathrm{SiO}_{2}, \mathrm{SO}_{4}, \mathrm{Na}, \mathrm{Br}, \mathrm{Ca}, \mathrm{Sr}, \mathrm{K}, \mathrm{Li}\right.$, and $\mathrm{Rb}$ ) suggesting that the high-temperature regions of the Piccard vent field are fed by a single source fluid that did not change composition during sampling occaisions (Table 1). High temperature endmember fluids at Piccard are depleted in $\mathrm{Cl}$ by $\sim 35 \%$ relative to seawater, with an endmember concentration of $349 \pm 8 \mathrm{mmol} / \mathrm{kg}$ (Fig. 2A). Dissolved $\mathrm{SiO}_{2}$ is highly enriched relative to seawater in the high-temperature vents, with an endmember concentration of $20.0 \pm 1.0$ $\mathrm{mmol} / \mathrm{kg}$ (Fig. 2B). Fluid $\mathrm{SO}_{4}$ abundances decrease linearly with respect to $\mathrm{Mg}$ to approximately near-zero abundances in endmember fluid $(0.21 \pm 0.17 \mathrm{mmol} / \mathrm{kg})$, while some of the mixed, lowtemperature fluids show depletions in $\mathrm{SO}_{4}$ content relative to conservative seawater-endmember mixing (Fig. 2C). The high-temperature endmember Na concentration is $313 \pm 7 \mathrm{mmol} / \mathrm{kg}$, corresponding to a depletion of $\sim 32 \%$ relative to seawater (Fig. 3A). Depletions relative to seawater are also observed in high-temperature endmember $\mathrm{Br}, \mathrm{Ca}$, and $\mathrm{Sr}$, which are $0.61 \pm 0.08$ $\mathrm{mmol} / \mathrm{kg}(\sim 26 \%), 6.26 \pm 1.14 \mathrm{mmol} / \mathrm{kg}(\sim 39 \%)$, and $21.9 \pm 1.4 \mathrm{mmol} / \mathrm{kg}(\sim 75 \%)$, respectively (Table 1, Fig. 3B, Fig. 3C). High-temperature fluids are enriched in the alkali metals K, Li and $\mathrm{Rb}$ relative to seawater, with endmember abundances of $11.3 \pm 0.6 \mathrm{mmol} / \mathrm{kg}, 422 \pm 21 \mu \mathrm{mol} / \mathrm{kg}$ and $5.59 \pm 0.28 \mu \mathrm{mol} / \mathrm{kg}$, respectively (Fig. 3D, 3E, 3F). Because $\mathrm{Cl}$ is the dominant anion in vent fluids, and charge balance constraints dictate that changes in $\mathrm{Cl}$ induce changes in dissolved cations, it is common practice to normalize elements to $\mathrm{Cl}$ to allow for identification of enrichments or depletions in vent fluid species relative to the starting seawater composition. Vent fluid $\mathrm{Na} / \mathrm{Cl}, \mathrm{Ca} / \mathrm{Cl}$, and $\mathrm{Br} / \mathrm{Cl}$ ratios are near seawater ratios, in contrast with the higher ratios observed for $\mathrm{K} / \mathrm{Cl}, \mathrm{Li} / \mathrm{Cl}$, and $\mathrm{Rb} / \mathrm{Cl}$, and the lower ratio observed for $\mathrm{Sr} / \mathrm{Cl}$ (Table 2). 
Endmember ${ }^{87} \mathrm{Sr} /{ }^{86} \mathrm{Sr}$ isotopic composition is $0.70456 \pm 25$, and is within the known global range for hydrothermal fluids (ALBARÈDE et al., 1981; RAVIzZA et al., 2001) (Fig. 4).

\subsection{Volatile aqueous species}

\subsubsection{Volatiles and carbon species in high-temperature fluids}

Vents at Beebe Vents 1, 3, and 5 and Beebe Woods are characterized by a single endmember value for each of the dissolved volatile species, $\mathrm{H}_{2}, \Sigma \mathrm{H}_{2} \mathrm{~S}, \Sigma \mathrm{CO}_{2}$, and $\mathrm{CH}_{4}$, further reinforcing that the high-temperature regions of the Piccard vent field are fed by a single source fluid that was of similar composition in 2012 and 2013 (Table 1). The Piccard endmember $\mathrm{H}_{2}$ abundance is $19.9 \pm 1.7 \mathrm{mmol} / \mathrm{L}$, and is highly enriched relative to seawater (Fig. $5 \mathrm{~A}$ ). Concentrations of this magnitude are substantially higher than $\mathrm{H}_{2}$ contents previously observed at other non-eruptive basalt-hosted vent fields, which typically contain $\leq 1 \mathrm{mmol} / \mathrm{L} \mathrm{H}_{2}$. Endmember $\Sigma \mathrm{H}_{2} \mathrm{~S}$ content is $12.0 \pm 1.2 \mathrm{mmol} / \mathrm{L}$ and is similar to abundances observed at other basalt-hosted high-temperature vents (Fig. 5B). Likewise, high-temperature $\delta^{34} \mathrm{~S}_{\mathrm{H} 2 \mathrm{~S}}$ values of +5.8 to $+6.3 \%$ are within the previously observed range (SHANKs, 2001) (Table 1). Hightemperature fluid $\Delta^{33} \mathrm{~S}_{\mathrm{H} 2 \mathrm{~S}}$ values of -0.004 to $-0.030 \%$ are near zero and similar to other values reported for black smokers elsewhere (CHAPTER 5).

Endmember $\Sigma \mathrm{CO}_{2}$ and $\mathrm{CH}_{4}$ concentrations are $25.7 \pm 1.3 \mathrm{mmol} / \mathrm{kg}$ and $124 \pm 15 \mu \mathrm{M}$ respectively (Fig. 6A and 6B). These $\Sigma \mathrm{CO}_{2}$ and $\mathrm{CH}_{4}$ abundances are similar to other unsedimented black smoker vent fluids. Endmember $\delta^{13} \mathrm{C}_{\mathrm{CO} 2}$ values are similar in Beebe Vents 1,3 and 5 and Beebe Woods, ranging from -4.8 to $-3.8 \%$ (Table 3), and fall within the range anticipated for degassing of $\Sigma \mathrm{CO}_{2}$ from basaltic magmas (PINEAU and JAVOY, 1983). Measured $\delta^{13} \mathrm{C}_{\mathrm{CH} 4}$ values are also constant in all Piccard black smokers, ranging from -23.6 to $-24.3 \%$ 
(Table 3), similar to values in other unsedimented black smoker fields. Endmember $\mathrm{C}_{2} \mathrm{H}_{6}$ abundance ranges from 11 to $15 \mathrm{nmol} / \mathrm{kg}$ at Beebe Vents 3 and 5 and is $28 \mathrm{nmol} / \mathrm{kg}$ at Beebe Woods (Fig. 6C). The combined $\delta^{13} \mathrm{C}_{\mathrm{C} 2 \mathrm{H} 6}$ value of $-24.9 \%$ or the Beebe Vent 1,3 , and 5 samples (see methods section) matches the Beebe Woods $\delta^{13} \mathrm{C}_{\mathrm{C} 2 \mathrm{H} 6}$ value of $-24.4 \%$ (Table 3). Measured endmember $\mathrm{C}_{3} \mathrm{H}_{8}$ concentrations at Beebe Vent 5 and Beebe Woods were 7.6 and 16 $\mathrm{nmol} / \mathrm{kg}$, respectively (Fig. 6D). Endmember $\mathrm{n}-\mathrm{C}_{4} \mathrm{H}_{10}$ ranges from 1.2 to $2.5 \mathrm{nmol} / \mathrm{kg}$ at Beebe Vents 3 and 5 and is $7.6 \mathrm{nmol} / \mathrm{kg}$ at Beebe Woods. Endmember $\mathrm{i}-\mathrm{C}_{4} \mathrm{H}_{10}$ is $1.3 \mathrm{nmol} / \mathrm{kg}$ at Beebe Vent 5 and is $3.4 \mathrm{nmol} / \mathrm{kg}$ at Beebe Woods. Endmember $\Sigma \mathrm{C}_{4} \mathrm{H}_{10}\left(\Sigma \mathrm{C}_{4} \mathrm{H}_{10}=\mathrm{n}-\mathrm{C}_{4} \mathrm{H}_{10}+\mathrm{i}-\mathrm{C}_{4} \mathrm{H}_{10}\right)$ is plotted in Fig. 6E.

Fluid ${ }^{14} \mathrm{C}_{\mathrm{CO} 2}$ and ${ }^{14} \mathrm{C}_{\mathrm{CH} 4}$ contents are near the detectable limit (Table 4). Dissolved formate species $\left(\Sigma \mathrm{HCOOH}=\mathrm{HCOOH}+\mathrm{HCOO}^{-}\right)$are below detection $(1 \mu \mathrm{mol} / \mathrm{kg})$ in Beebe Vents 1, 3 and 5, but are detectable in the Beebe Woods fluid, which contains an endmember $\Sigma \mathrm{HCOOH}$ abundance of $4.8 \mu \mathrm{mol} / \mathrm{kg}$ (Fig. 6F). The isotopic composition of He in the Piccard vent fluids indicates $R / R_{a}$ values of 8.30 to 8.41 (Table 1 ) that are consistent with a mantle source (CRAIG and LUPTON, 1976; LUPTON and CRAIG, 1975). Measured $\Sigma \mathrm{CO}_{2} /{ }^{3} \mathrm{He}$ ratios in Beebe Vents 1 and $5\left(5.45\right.$ to $\left.6.43 \times 10^{8}\right)$ are just below the average ratio measured in mantle rocks $\left(1 \times 10^{9}\right)($ MARTY and TOLSTIKHIN, 1998).

\subsubsection{Volatiles and carbon species in mixed, low-temperature fluids}

Conservative behavior is observed for $\Sigma \mathrm{CO}_{2}$ in mixed, low-temperature fluids at Piccard, indicating that there is no substantial loss or gain of $\Sigma \mathrm{CO}_{2}$ during mixing between the endmember source fluid and seawater (Fig. 6A). Endmember $\delta^{13} \mathrm{C}_{\mathrm{CO} 2}$ values in mixed fluids range from $-5.7 \%$ o to $-3.8 \%$ and are similar to endmember values (Table 4). Dissolved $\mathrm{H}_{2}$, 
$\Sigma \mathrm{H}_{2} \mathrm{~S}, \mathrm{CH}_{4}, \mathrm{C}_{2} \mathrm{H}_{6}, \mathrm{C}_{3} \mathrm{H}_{8}, \mathrm{n}-\mathrm{C}_{4} \mathrm{H}_{10}, \mathrm{i}-\mathrm{C}_{4} \mathrm{H}_{10}$ and $\Sigma \mathrm{HCOOH}$ are all enriched or depleted in abundance relative to conservative mixing indicating sources and sinks during mixing between an endmember fluid and seawater in the subsurface. Piccard mixed fluids show depletions in $\mathrm{H}_{2}$ and $\Sigma \mathrm{H}_{2} \mathrm{~S}$ as high as $92 \%$ and $43 \%$, respectively, relative to conservative mixing (Fig. 5A, 5B). The same fluids also show significant enrichments in $\mathrm{CH}_{4}, \mathrm{C}_{2} \mathrm{H}_{6}, \mathrm{C}_{3} \mathrm{H}_{8}, \Sigma \mathrm{C}_{4} \mathrm{H}_{10}\left(\Sigma \mathrm{C}_{4} \mathrm{H}_{10}=\mathrm{n}\right.$ $\mathrm{C}_{4} \mathrm{H}_{10}+\mathrm{i}-\mathrm{C}_{4} \mathrm{H}_{10}$ ), and $\Sigma \mathrm{HCOOH}$ relative to conservative mixing (Fig. 6). Mixed fluid hydrocarbon $\delta^{13} \mathrm{C}$ values determined in Hot Chimlet \#1, \#2, and \#3 fluids are ${ }^{13} \mathrm{C}$-depleted relative to the endmember, with $\delta^{13} \mathrm{C}_{\mathrm{CH} 4}, \delta^{13} \mathrm{C}_{\mathrm{C} 2 \mathrm{H} 6}$, and $\delta^{13} \mathrm{C}_{\mathrm{C} 3 \mathrm{H} 8}$ values ranging from $-28.4 \%$ to $29.9 \%$, $-33.3 \%$ to $-36.9 \%$, and $-28.2 \%$ to $-29.7 \%$, respectively (Table 4 ).

\subsection{Transition Metals}

\subsubsection{High-temperature fluids}

Transition metals in Piccard high-temperature fluids sampled in 2012 are highly enriched relative to seawater with Beebe Vent 1, 3, and 5 fluids characterized by Fe endmember abundances, ranging from 6.5 to $6.7 \mathrm{mmol} / \mathrm{kg}$ (Table 6, Fig. 7A). Beebe Woods fluids extrapolate to a higher endmember Fe content $(13 \mathrm{mmol} / \mathrm{kg})$, as is also observed for several other metals (below). Beebe Vent 1, 3, and 5 and Beebe Woods display uniform endmember Mn abundances, ranging from 553 to $557 \mu \mathrm{mol} / \mathrm{kg}$ (Fig. 7B). Endmember abundances for $\mathrm{Zn}$ and $\mathrm{Cu}$ range from 36 to $75 \mu \mathrm{mol} / \mathrm{kg}$ and 172 to $235 \mu \mathrm{mol} / \mathrm{kg}$ at Beebe Vents 1,3 , and 5 and are 46 and $666 \mu \mathrm{mol} / \mathrm{kg}$ at Beebe Woods, respectively (Fig. 7C, 7D). The endmember Al contents of Beebe Vents 1, 3, and 5 and Beebe Woods are similar across the Piccard field and range from 6.1 to 8.3 $\mu \mathrm{mol} / \mathrm{kg}$ (Fig. 8A). The endmember Pb contents of Beebe Vents 1, 3, and 5 and Beebe Woods show wider variability and range from 0.094 to $1.7 \mu \mathrm{mol} / \mathrm{kg}$ (Fig. 8B). The endmember Co 
contents of Beebe Vents 1, 3, and 5 are lower than those at Beebe Woods, ranging from 0.98 to $1.1 \mu \mathrm{mol} / \mathrm{kg}$, versus $15 \mu \mathrm{mol} / \mathrm{kg}$, respectively (Fig. 8C). The endmember Cd contents of Beebe Vents 1, 3, and 5 are higher than those at Beebe Woods, ranging from 78 to $94 \mathrm{nmol} / \mathrm{kg} v s .52$ nmol/kg, respectively (Fig. 8D).

When entrainment of metal-rich particles from the deposits surrounding a vent occurs, these particles are then included in the 'dregs' metals aliquots and appear as enrichments in the reconstituted fluid metal budgets. Due to the friable nature of the beehive chimney surrounding the Beebe Woods vent, particle entrainment into the fluid sample was possible. Indeed, the metal enrichments at Beebe Woods are primarily observed in the 'dregs' fraction, and the 'dissolved' and 'filter' fractions do not have substantially elevated metal contents relative to Beebe Vent 1, 3 and 5 (Tables A1, A2, A3).

If instead, pyrrhotite, pyrite, or chalcopyrite dissolution and metal remobilization had occurred in the subsurface of Beebe Woods, adding 4 to $7 \mathrm{mmol}$ of dissolved Fe to the fluid, then enrichments of 4 to $14 \mathrm{mmol} / \mathrm{L}$ in $\Sigma \mathrm{H}_{2} \mathrm{~S}$ would be expected, as well as a drop in fluid $\mathrm{pH}$. In addition, pyrrhotite and chalcopyrite redissolution would result in consumption of 2 to $7 \mathrm{mmol} / \mathrm{L}$ $\mathrm{H}_{2}$. Beebe Woods fluid $\mathrm{pH}$ and $\Sigma \mathrm{H}_{2} \mathrm{~S}$ and $\mathrm{H}_{2}$ contents match those of Beebe Vent 1, 3, and 5, however, providing no evidence to support subsurface sulfide redissolution. It is most likely that the elevated metals reflect accidental entrainment of metal-rich particles during sampling.

\subsubsection{Transition metals in mixed, low-temperature fluids}

Mixed fluids sampled in 2012 show variable enrichments and depletions in transition metals, relative to conservative mixing between seawater and the 'average' Beebe Vents 1, 3, and 5 endmember. The inclusion of the dregs and filter fractions are particularly important for 
mixed fluids, as metal-rich particles form readily within the fluid samplers and must be added back in to reflect the reconstituted fluid composition. Note that a dregs fraction for the lowerMg sample collected at Hot Chimlet \#1 was not collected (Appendix Table A3), hence deviations from conservative behavior are only considered for the higher-Mg Hot Chimlet \#1 sample, which reflects complete analysis of the dissolved, filtered, and dregs fractions. Mixed fluids are variably enriched and depleted in Fe, with a maximum enrichment of $\sim 50 \%$ in Shrimp Gulley \#1 and maximum depletion of $\sim 60 \%$ in Hot Chimlet \#1 (Fig. 7A). The Hot Chimlet \#1 fluid is enriched in Mn by $\sim 35 \%$ relative to conservative mixing, while other mixed fluid $\mathrm{Mn}$ contents reflect conservative mixing (Fig. 7B). The Hot Chimlet \#1 fluid is also the most depleted in $\mathrm{Zn}$ and $\mathrm{Cu},(\sim 92 \%$ and $\sim 85 \%$, respectively), while the other mixed fluids behave conservatively within error, aside from one Shrimp Gulley \#1 fluid which is enriched in $\mathrm{Cu}$, perhaps reflecting particle contamination in that sample (Fig. 7C, 7D). All mixed fluids are enriched in Al, relative to conservative mixing (Fig. 8A). Conservative behavior is observed for mixed fluid $\mathrm{Pb}$ and $\mathrm{Co}$ contents (Fig. 8B, 8C). The Hot Chimlet \#1 fluid is depleted in $\mathrm{Cd}$ by $\sim 82 \%$ relative to conservative mixing, while other mixed fluid $\mathrm{Cd}$ contents reflect conservative mixing (Fig. 8D).

\section{DisCuSSION}

Vent fluid circulation in convective deep-sea hydrothermal systems worldwide share common formation characteristics. The composition of a seafloor vent fluid reflects the cumulative influence of a variety of factors, including the initial bottom seawater composition, the composition of the rock through which the fluid circulates, the depth of circulation, and the nature of the heat source. These last two factors determine the pressure and temperature 
conditions of water-rock reaction and establish whether or not the fluid reaches the two-phase boundary, triggering phase separation (BISCHOFF and RosenBAUER, 1985; Fig. 9A). Seawater descends through permeable rock within the 'recharge' zone, first undergoing lower temperature chemical reactions. Further reaction occurs during progressive heating with increasing depth, until the fluid attains its highest temperature in the 'reaction' zone. As seawater circulates through the hydrothermal system, its composition is modified by water-rock reaction. Because hot fluids are buoyant relative to cold seawater, they ascend through the 'discharge' zone toward the seafloor. In basalt-hosted hydrothermal systems, the integrated effect of hydrothermal circulation is the transformation of seawater into a $\mathrm{Mg}$ - and $\mathrm{SO}_{4}$-poor, slightly acidic, anoxic fluid that is enriched in alkalis, $\mathrm{Ca}, \mathrm{SiO}_{2}$, metals, $\mathrm{H}_{2} \mathrm{~S}$, and $\Sigma \mathrm{CO}_{2}$, and vents at the seafloor at temperatures that are often between $350^{\circ} \mathrm{C}$ and $400^{\circ} \mathrm{C}$.

\subsection{Processes controlling the formation of endmember 'black smoker' fluids}

\subsubsection{Phase separation}

Several lines of evidence indicate that the endmember black smoker fluids emanating from the Piccard vent field attained higher temperatures at depth, relative to their measured seafloor temperatures. Due to a lack of a significant sink for $\mathrm{Cl}$ within basalt-hosted subsurface circulation pathways, $\mathrm{Cl}$ depletions in vent fluids are typically attributed to phase separation (VOn Damm, 1990, 1995; German and Seyfried, 2014). Thus, Cl depletions in Beebe Vents and Beebe Woods endmember fluids are likely the result of supercritical phase separation that was triggered when temperature and pressure conditions exceeded the two-phase boundary above the critical point of seawater $\left(407^{\circ} \mathrm{C}, 298\right.$ bar) (BISCHOFF, 1991; Fig. 2A). During incipient supercritical phase separation, a small amount of high-salinity 'brine' phase fluid will 
be condensed, with the result that the remainder of the fluid, the 'vapor' phase, will contain less $\mathrm{Cl}$ than seawater. This vapor phase, or some fraction of it, is what is presumed to be venting at Piccard. At Piccard seafloor conditions (496 bar), the two-phase boundary of seawater is $483^{\circ} \mathrm{C}$, thus this is the minimum temperature that the fluids must have attained in the subsurface to induce phase separation, indicating that the fluids have cooled by more than $80^{\circ} \mathrm{C}$. Since Piccard fluids were not actively phase separating at the seafloor, and may circulate to subsurface depths of several kilometers, as is often seen at other mid-ocean ridges, then they may have phase separated at even higher temperatures, possibly far in excess of $500^{\circ} \mathrm{C}$ (SOURIRAJAN and KENNEDY, 2006).

\subsubsection{Quartz equilibrium and fluid $\mathrm{SiO}_{2}$ abundances}

Quartz geothermometry also supports very high reaction zone temperatures at Piccard. The $\mathrm{SiO}_{2}$ content of high temperature hydrothermal fluids has been used to estimate the depth (pressure) of water-rock reaction in basalt hosted systems, under the assumption that fluid $\mathrm{SiO}_{2}$ equilibrates with quartz in the reaction zone as a function of temperature and pressure (and salinity to a lesser extent) (FOURNIER, 1983) and does not reequilibrate during ascent through the discharge zone (BISCHOFF and RosenBAUER, 1985; VON DAMM et al., 1991). Examination of Figure 9 reveals that the Piccard fluids could not have equilibrated with quartz at the measured vent temperatures since this would require a pressure of 400 bar that places the reaction zone 100 $\mathrm{m}$ above the seafloor. A likely scenario is that fluids equilibrated with quartz at temperatures substantially higher than the measured seafloor temperature, but subsequently cooled prior to venting. Because quartz solubility at high temperatures and low pressures is characterized by a retrograde temperature dependence, higher temperature equilibration requires increasing 
pressures for the observed $\mathrm{SiO}_{2}$, concentrations at Piccard, placing the reaction zone below the seafloor (Fig. 9). Although quartz solubility has not been determined at temperatures $>450^{\circ} \mathrm{C}$, comparison of the $\mathrm{SiO}_{2}$ contents of Piccard fluids with existing solubility measurements suggests that these fluids have equilibrated with quartz at temperatures $>450^{\circ} \mathrm{C}$, and perhaps exceeding, $500^{\circ} \mathrm{C}$. The temperatures inferred from dissolved $\mathrm{SiO}_{2}$ contents and quartz geothermometry are therefore consistent with the temperatures required for supercritical phase separation.

\subsubsection{Effects of fluid/rock reaction on major ion and alkali abundances}

High dissolved $\mathrm{SiO}_{2}$ and $\Sigma \mathrm{H}_{2} \mathrm{~S}$ abundances, coupled with strong enrichments in $\mathrm{K}$ and low $\mathrm{Ca}$ contents in the high-temperature Piccard fluids are consistent with fluid/rock reaction with basaltic substrate at high temperatures. In basalt-hosted systems, the $\mathrm{Na}$ and $\mathrm{Ca}$ content of vent fluids is controlled by pressure and temperature-dependent thermodynamic equilibrium with plagioclase minerals and their alteration products (BERNDT and SEYFRIED, 2002; BERNDT et al., 1989; SEYFRIED, 1987).

Because $\mathrm{Cl}$ is the dominant anion in vent fluids, and most cations in hydrothermal fluids are transported as chloro-complexes, their concentrations are related to fluid $\mathrm{Cl}$ contents. Therefore, it is helpful to examine element-to-Cl ratios in addition to absolute abundances (VON DAmM, 1995). Piccard $\mathrm{Na} / \mathrm{Cl}$ ratios are within the range observed at unsedimented basalt-hosted MORs (GALLANT and VON DAMM, 2006), however $\mathrm{Ca} / \mathrm{Cl}$ ratios are significantly lower than

seawater (Table 2). The low fluid Ca contents observed are consistent with fluid/rock reaction at very high temperatures. With increasing temperature, Ca will be removed from solution via incorporation into solid phases, such as clinozoisite, which is thermodynamically favored over anorthite at higher temperatures (SEYFRIED and JANECKY, 1985; SEYFRIED, 1987): 


$$
3 \mathrm{CaAl}_{2} \mathrm{Si}_{2} \mathrm{O}_{8(\mathrm{~s})}+\mathrm{Ca}^{2+}(a q)+2 \mathrm{H}_{2} \mathrm{O}=2 \mathrm{Ca}_{2} \mathrm{Al}_{3} \mathrm{Si}_{3} \mathrm{O}_{12}(\mathrm{OH})_{(\mathrm{s})}+2 \mathrm{H}_{(a q)}^{+}
$$

Anorthite

Clinozoisite

Greater removal of $\mathrm{Ca}$ from solution with increasing temperature at $200^{\circ} \mathrm{C}$ to $500^{\circ} \mathrm{C}$ has been demonstrated in early experiments reacting seawater with basalt (MOTTL and HOLLAND, 1978). Along with fluid $\mathrm{Cl}$ and $\mathrm{SiO}_{2}$ contents, the low seawater-normalized $\mathrm{Ca}$ contents of Piccard fluids reinforce our interpretation that the fluids were generated under very high temperature conditions.

Water/rock ratios (w/r) can be calculated using Sr abundance and isotopes, and using abundances of the alkali elements $\mathrm{Li}$ and $\mathrm{Rb}$, to determine the relative mass of fluid and rock that have undergone reaction to generate the Piccard fluids. Typically $\mathrm{w} / \mathrm{r}$ ratios calculated using $\mathrm{Sr}$ yield values that are an order of magnitude higher than those calculated for alkali elements (BERNDT et al., 1988). This contrast in $\mathrm{w} / \mathrm{r}$ ratios arises due to differences in the location in the rock of these elements. The alkali metals are relatively incompatible with mineral sites, thus they are concentrated in more chemically unstable mineral phases and glasses. The alkali-rich phases are therefore easily leached and only minimally impacted by incorporation into secondary minerals. In contrast, $\mathrm{Sr}$ is concentrated in plagioclase minerals, which are distributed more homogenously as a major phase throughout basalts and gabbros. The alkali metal w/r ratios therefore provide a sense for the amount of alkali-containing minerals altered, while $\mathrm{w} / \mathrm{r}$ ratios derived from $\mathrm{Sr}$ give a sense for the degree of aleration of Sr-contining minerals and recrystallization to form secondary minerals.

Vent fluid Sr content typically correlates with $\mathrm{Ca}$, as reactions involving Ca-bearing primary and secondary mineral phases also control Sr abundances (BERNDT et al., 1988). The 
Piccard Sr concentration is depleted relative to seawater, although still within the range observed at high-temperature mid-ocean ridge systems (GALLANT and VON DAMM, 2006), and the $\mathrm{Sr} / \mathrm{Cl}$ ratio indicates that fluids have lost dissolved $\mathrm{Sr}$ during fluid/rock reaction on a seawaternormalized basis. An average endmember ${ }^{87} \mathrm{Sr} /{ }^{86} \mathrm{Sr}$ ratio of 0.70456 calculated for the low $\mathrm{Mg}$ endmember fluids is consistent with a predominantly rock source of $\mathrm{Sr}$ (Fig. 4). BERNDT et al. (1988) describe a model in which the evolution of $\mathrm{Sr}$ abundance and isotopic composition in hydrothermal fluids can be modeled in the context of incomplete Sr removal by anhydrite precipitation in the recharge zone (substitution for $\mathrm{Ca}$ ) and simultaneous addition of $\mathrm{Sr}$ from dissolution of $\mathrm{Ca}$ - and Sr-bearing plagioclase minerals during high-temperature fluid/rock reaction. Sr isotopes do not fractionate during precipitation or dissolution reactions and can be used to estimate water/rock ratios during fluid-rock interaction.

Application of the simultaneous dissolution and precipitation model developed by BERNDT et al. (1988) permits calculation of a fluid/rock ratio that is parameterized by simultaneous release of rock-derived $\mathrm{Sr}$ and precipitation of $\mathrm{Sr}$ into secondary mineral phases (eqn. 11, 12, 13 in BERNDT ET AL., 1998). The bulk Sr content of MCR basalts is similar to other MOR basalt values worldwide, with an average abundance of 192 ppm (COHEN and O'NiONs, 1982; ELTHON et al., 1995) and ${ }^{87} \mathrm{Sr} /{ }^{86} \mathrm{Sr}$ ratio of 0.7025 (COHEN and O'NiONS, 1982; Fig.4). Fluid $\mathrm{Sr}$ contents have likely been impacted by phase separation. One potential scenario is that the fluid Sr abundance and isotope signature was set prior to phase separation. Thus it is helpful to normalize fluid $\mathrm{Sr}$ abundances to seawater chlorinity. Keeping these assumptions in mind and using average basalt values, the fluid/rock ratio for the high-temperature Piccard fluid is calculated to fall in the range 40 to 60 (the former ratio calculated for observed fluid $\mathrm{Sr}$, the latter for Cl-normalized Sr abundance) (Fig. 10). 
Experimental and field studies demonstrate that the alkali elements are highly mobile during fluid/rock reaction, and are nearly quantitatively leached from the rock during hightemperature basalt alteration (MotTl and Holland, 1978; SEYFried et al., 1984; VON DAMM, 1990; Von Damm et al., 1985). Indeed, fluid $\mathrm{K}, \mathrm{Li}$, and $\mathrm{Rb}$ contents are enriched over seawater. If it is assumed that $\mathrm{Li}$ and $\mathrm{Rb}$ are leached quantitatively from basalt of known $\mathrm{Li}$ and $\mathrm{Rb}$ content, and that these species are not partitioned into any secondary mineral phases, then a fluid/rock ratio can be calculated (VON DAMM et al., 1985). Mid-Cayman Rise basalt contains $1.92 \mathrm{ppm} \mathrm{Rb}$ according to a single measurement of an axial basalt (COHEN and O'NIONS, 1982). Although the Li content of Mid-Cayman Rise basalts is unknown, a recent study of axial basalts dredged from $13-14^{\circ} \mathrm{N}$ MAR (west of the $13^{\circ} 19^{\prime} \mathrm{N}$ oceanic core complex) reports $6.11 \mathrm{ppm} \mathrm{Rb}$ and $5.11 \mathrm{ppm} \mathrm{Li}(\mathrm{n}=109)$ (WILSON et al., 2013), and the larger sample set and ICP-MS methodology used for that study may better reflect the average composition of basalt erupted at slow and ultraslow spreading centers. Average high-temperature fluid endmember Rb contents $(5.59 \mu \mathrm{mol} / \mathrm{kg})$ therefore yield a fluid/rock ratio of $\sim 0.8(1.92 \mathrm{ppm} \mathrm{Rb})$ or $\sim 1(6.11 \mathrm{ppm} \mathrm{Rb})$, while average high-temperature fluid endmember Li contents $(422 \mu \mathrm{mol} / \mathrm{kg})$ yield a fluid $/$ rock ratio of $\sim 0.5$. The relatively low $\mathrm{Li}$ - and $\mathrm{Rb}$-based fluid/rock ratios likely indicate that Piccard fluids have reacted under rock-dominated conditions.

\subsubsection{The effect of high temperature fluid/rock reaction on fluid $\mathrm{H}_{2}$ abundance}

A striking feature of vent fluid chemistry at Piccard is the very high aqueous $\mathrm{H}_{2}$ content of the high temperature endmember fluids. The endmember concentration of $21 \mathrm{mmol} / \mathrm{L}$ at Beebe Vents 1, 3 and 5 and Beebe Woods is higher than abundances observed at ultramaficinfluenced systems such as Von Damm, Rainbow, and Lost City (CHAPTER 1, CHAPTER 2) 
(ChARlou et al., 2002; ChARlou et al., 2010; ProskUROWSKI et al., 2008).

Experimental and theoretical studies have demonstrated that dissolved $\mathrm{H}_{2}$ concentrations are regulated by fluid-mineral equilibria during high temperature, high-pressure seawater-basalt alteration. Overall, $\mathrm{H}_{2}$ abundances in basalt-hosted hydrothermal systems are buffered by equilibration with Fe-bearing oxides, sulfides, and aluminosilicate minerals (SEYFRIED, 2003; SEYFRIED and Ding, 1995; SEYFrIED et al., 2003). Another consideration is that dissolved volatiles such as $\mathrm{H}_{2}$ (and $\Sigma \mathrm{H}_{2} \mathrm{~S}, \Sigma \mathrm{CO}_{2}$ ) will preferentially partition into a low salinity vapor phase fluid produced by phase separation (SEYFRIED and DING, 1995), as is inferred to have occurred at Piccard. Piccard $\mathrm{H}_{2}$ contents are an order of magnitude higher than the abundances frequently observed in low salinity vapor phase fluids venting at other basalt-hosted mid-ocean ridge hydrothermal systems, however. Therefore the effects of phase separation, alone, are likely insufficient to explain the observed $\mathrm{H}_{2}$ enrichments. Furthermore, the other volatile species at Piccard, such as $\mathrm{CH}_{4}, \Sigma \mathrm{H}_{2} \mathrm{~S}$, and $\Sigma \mathrm{CO}_{2}$ are not similarly enriched relative to observations elsewhere.

Instead, it is possible that, due to the great depth of the Mid-Cayman Rise axis, it is the exceptionally high temperature of fluid/rock reaction that is responsible for the high dissolved $\mathrm{H}_{2}$ abundances. Experimental studies examining the temperature effect on $\mathrm{H}_{2}$ generation in saline fluids reacting with basalt and with mineral assemblages present at reaction zone conditions, including pyrite-pyrrhotite-magnetite and anorthite-epidote-anhydrite-magnetite, at $275^{\circ} \mathrm{C}$ to $425^{\circ} \mathrm{C}$ and 400 bar, suggest that fluid $\mathrm{H}_{2}$ contents increase with increasing temperatures of fluid/rock reaction. Laboratory experiments conducted at the higher temperatures and pressure conditions inferred for Piccard are currently lacking, however a theoretical perspective can be gained from equilibrium thermodynamic modeling at the conditions of interest. 
Thermodynamic reaction-path modeling can be used to assess the effects of temperature during fluid-basalt interaction. To test whether high temperature reaction of basalt with seawater could generate $\mathrm{H}_{2}$ abundances of the magnitude observed at Piccard, a reaction path model was constructed using the computer code EQ3/6, version 8.0 (WOLERY, 1992; WOLERY and DAVELER, 1992) to examine the effects of possible reaction temperatures $\left(400\right.$ to $\left.600^{\circ} \mathrm{C}\right)$ and $\mathrm{w} / \mathrm{r}$ ratios (1 to 20) estimated for Piccard. All model runs were conducted at 1000 bar, which corresponds to $\sim 5 \mathrm{~km}$ circulation depth below the seafloor at Piccard. A customized 1000 bar thermodynamic database was assembled using SUPCRT92 (JOHNSON et al., 1992) that contains thermodynamic data from (SHOcK et al., 1989; SHOCK et al., 1997; SHOCK and HelGeSON, 1988) for aqueous species and from (HELGESON et al., 1978; MCCOLlOM and BACH, 2009) for minerals. Controls on the production of $\mathrm{H}_{2}$ were assessed by a model constructed via three consecutive steps. In step one, $1000 \mathrm{~g}$ of seawater was speciated at $25^{\circ} \mathrm{C}$ and $1000 \mathrm{bar}$ using EQ3NR (WOLERY, 1992). In step two, the seawater was heated to the temperature of interest (400 to $600^{\circ} \mathrm{C}$ ) at 1000 bar using EQ6 (WOLERY and DAVELER, 1992). In step three, a set quantity of normal-mid ocean ridge basalt (NMORB) was added to replicate w/r mass ratios of either 1,10 , or 20 , and the entire system was reacted at the temperature of interest and 1000 bar, allowing minerals to precipitate. Dolomite, calcite, magnesite, siderite, antigorite, and ferrikaolinite were suppressed, as they are not expected to form at reaction zone conditions.

Reaction-path model results show that fluid $\mathrm{H}_{2}$ contents are predicted to increase with increasing temperature and with lower $\mathrm{w} / \mathrm{r}$ ratios (Fig. 11). Higher $\mathrm{H}_{2}$ is associated with the formation of relatively greater amounts of Fe oxides in the predicted mineral assemblage. At a lower temperature of $400^{\circ} \mathrm{C}$, epidote is predicted to form in association with anhydrite, diaspora, tremolite, chlorite, talc, and plagioclase. At higher temperatures of $500^{\circ} \mathrm{C}$ to $550^{\circ} \mathrm{C}$, magnetite is 
predicted to form with anhydrite, tremolite, talc, and plagioclase. Model results for w/r ratio of 1 and 10 generate $\sim 20 \mathrm{mmol} / \mathrm{kg}$ at $500^{\circ} \mathrm{C}$ (Fig. 11). These results are consistent with the w/r ratios and reaction temperatures estimated for Piccard from inorganic fluid chemistry, and support high temperature fluid/basalt reaction as a potential source of the exceptionally high $\mathrm{H}_{2}$ contents observed at this basalt-hosted hydrothermal system.

\subsubsection{Effects of fluid/rock reaction on high-temperature fluid $\mathrm{\Sigma}_{2} \mathrm{~S}$ and metal contents}

Dissolved $\Sigma \mathrm{H}_{2} \mathrm{~S}$ abundances in the Beebe Vents 1, 3, and 5 and Beebe Woods in 2012 and 2013 reflect the high temperatures of water-rock reaction at Piccard, and are high relative to the endmember $\Sigma \mathrm{H}_{2} \mathrm{~S}$ contents of other basalt-hosted black smoker systems on the slow spreading MAR, such as TAG, $26^{\circ} \mathrm{N}$ (3-4 mmol/L), Snakepit, $23^{\circ} \mathrm{N}$ (6.0 mmol/L), Menez Gwen, $37^{\circ} 50^{\prime} \mathrm{N}(<1.5 \mathrm{mmol} / \mathrm{L})$ and Lucky Strike, $37^{\circ} 17^{\prime} \mathrm{N}(0.6$ to $3.4 \mathrm{mmol} / \mathrm{L})$ (DouviLLE et al., 2002). Although controls on $\Sigma \mathrm{H}_{2} \mathrm{~S}$ are also redox-and Cl-dependent, increasing temperatures of fluid/rock reaction are expected to generate higher fluid $\mathrm{\Sigma H}_{2} \mathrm{~S}$ contents (SEYFRIED and JANECKY, 1985; SEYFRIED and Ding, 1995; SEYFRIED et al., 2003).

Sulfur isotope analysis of vent fluid $\Sigma \mathrm{H}_{2} \mathrm{~S}$ shows low variability in $\delta^{34} \mathrm{~S}$ values $(+5.8 \%$ o to $+6.3 \%$ ). The major contributors to $\Sigma \mathrm{H}_{2} \mathrm{~S}$ in vent fluids at unsedimented MOR hydrothermal systems are basalt-derived sulfide (pyrite and pyrrhotite) of mantle origin, with an average $\delta^{34} \mathrm{~S}$ value of $+0.1 \pm 0.5 \%$ (SAKAI et al., 1984), and reduced seawater $\mathrm{SO}_{4}$, with a $\delta^{34} \mathrm{~S}$ value of $+21.0 \pm 0.2 \%$ (REES et al., 1978). Piccard $\delta^{34} \mathrm{~S}_{\mathrm{H} 2 \mathrm{~S}}$ values suggest that seawater $\mathrm{SO}_{4}$ persisting into the reaction zone underwent reduction to $\mathrm{\Sigma H}_{2} \mathrm{~S}$ via oxidation of gabbroic and/or basaltic sulfide (Shanks and SEyfried, 1987; WoOdrufF and Shanks, 1988), and dissolution of rock-derived 
sulfide generated endmember fluid $\delta^{34} \mathrm{~S}$ values that reflect contributions of mantle-derived sulfur that varied from 72 to $70 \%$ relative to seawater-derived sulfur contributions of 28 to $30 \%$.

During shallow subsurface fluid-seawater mixing, fluid $\Sigma \mathrm{H}_{2} \mathrm{~S}$ could be impacted by isotope exchange with $\mathrm{SO}_{4}$ that is derived from subseafloor anhydrite deposits or entrained seawater $\mathrm{SO}_{4}$. A recent multiple-stable sulfur isotope study has demonstrated that isotope exchange between $\mathrm{SO}_{4}$ and $\mathrm{H}_{2} \mathrm{~S}$ can result in elevated $\Sigma \mathrm{H}_{2} \mathrm{~S} \Delta^{33} \mathrm{~S}$ values for $\mathrm{H}_{2} \mathrm{~S}$ in hightemperature fluids (ONO et al., 2007). Piccard vent fluid $\Sigma \mathrm{H}_{2} \mathrm{~S}$ is characterized by near-zero $\Delta^{33} \mathrm{~S}$ values, however, indicating normal mass-dependent fractionation, similar to what is more typically observed in other black smokers worldwide (e.g. CHAPTER 5).

Dissolved metal abundances in black smoker fluids are influenced by $\mathrm{pH}$, and the stability of metal-chloro complexes, which are redox, pressure, and temperature dependent. Among the metals that are of highest abundance in hydrothermal vents, temperature-dependent equilibration rates are fastest for $\mathrm{Cu}$, followed by $\mathrm{Fe}, \mathrm{Zn}$, and finally $\mathrm{Mn}$ (SEEWALD and SEYFRIED, 1990). It is expected that fluid dissolved $\mathrm{Cu}$ and Fe contents would decrease more quickly due to a decrease in temperature, while $\mathrm{Zn}$ and $\mathrm{Mn}$ contents would be slower to respond and more likely to record high temperature concentrations. Field and experimental studies of hydrothermal vent fluids have shown evidence that many axial hot spring systems attain higher temperatures at depth (commonly 375 to $400^{\circ} \mathrm{C}$ ) and then lose heat prior to venting at the seafloor at temperatures that are often lower by 20 to $30^{\circ} \mathrm{C}$ (BERNDT et al., 1989; SEEWALD and SEYFRIED, 1990; SEYFRIED, 1987).

At Piccard, major dissolved species suggest that higher temperature fluids share a common origin. $\mathrm{Fe} / \mathrm{Mn}$ ratios that are higher at Beebe Woods $(23 \mathrm{~mol} / \mathrm{mol})$ than at the Beebe Vents 1,3 , and $5(12 \mathrm{~mol} / \mathrm{mol})$ reflect the addition of Fe due to coring and particle entrainment 
within the Beebe Woods samples (Table 2, Table A1, Table A2, Table A3). An empirical Fe/Mn geothermometer has been developed for basalt-hosted hydrothermal fluids up to temperatures of $450^{\circ} \mathrm{C}$ (PESTER et al., 2011) that is based upon the experimentally demonstrated temperature sensitivity and reaction reversibility of these two metals. The Piccard fluids are thought to have cooled from temperatures in excess of $483^{\circ} \mathrm{C}$, a temperature beyond the calibration range of PESTER et al. (2011). Moreover, the large extent of cooling likely resulted in precipitation of Fe. Nevertheless, it is still of interest to apply the geothermometer to fluid formation processes at Beebe Vents. The empirical geothermometer predicts a temperature of $452^{\circ} \mathrm{C}$ for Beebe Vents 1 , 3, and 5. These temperatures are cooler than the $\geq 500^{\circ} \mathrm{C}$ temperatures suggested by fluid $\mathrm{SiO}_{2}$ contents. It is indeed likely that fluid Fe/Mn ratios have been affected by fluid cooling at Piccard, and it is likely that the fluids have lost Fe, as well as $\Sigma \mathrm{H}_{2} \mathrm{~S}$, to sulfide precipitation prior to venting at the seafloor.

\subsection{Processes controlling the formation of mixed, low-temperature fluids}

The Hot Chimlet and Shrimp Gulley fluids at Piccard are generated during subsurface mixing of relatively cool, higher $\mathrm{pH}$ seawater with hot, acidic source fluids. Although many species show conservative behavior during mixing, several species behave non-conservatively. Here non-conservative behavior is examined to elucidate the processes that impact Piccard mixed fluids, including purely abiotic (non-biological), thermogenic (derived from thermal decomposition of living or once-living biomass), and biogenic (derived from the metabolic products of viable micro-organisms) reactions. 


\subsubsection{The fate of the missing $\mathrm{H}_{2}$ in mixed fluids}

In several studies examining the geochemistry of hydrothermal vent fluids in mixing zones within temperature regimes cooler than the currently known $122^{\circ} \mathrm{C}$ limit for life (TAKAI et al., 2008), depletions in $\mathrm{H}_{2}$ and enrichments in $\mathrm{CH}_{4}$ have been attributed to microbial production via active methanogenesis (VON DAMm and Lilley, 2004; WANKel et al., 2011). At Piccard, substantial $\mathrm{H}_{2}$ depletions occur in the $149^{\circ} \mathrm{C}$ Hot Chimlet fluid, which exceeds the known temperature limit for life. Consumption of $\mathrm{H}_{2}$ at Hot Chimlet must therefore be an abiotic process.

The $149^{\circ} \mathrm{C}$ Hot Chimlet fluid has lost a net $\sim 4.1 \mathrm{mM} \mathrm{H}_{2}$, relative to concentrations expected for conservative mixing. Precipitation of iron rich oxides, oxyhydroxides, and sulfides would impact fluid $\mathrm{H}_{2}$ budgets. For example, pyrite precipitation is thought to be a dominant process affecting many mixed fluids in hydrothermal systems:

$$
\mathrm{Fe}^{2+}+2 \mathrm{H}_{2} \mathrm{~S}_{(a q)}=\mathrm{FeS}_{2(s)}+2 \mathrm{H}^{+}+\mathrm{H}_{2(a q)}
$$

There is a loss of $1.3 \mathrm{mmol} / \mathrm{kg} \mathrm{Fe}$ observed in the fluid. If this Fe was lost due to pyrite formation, then $1.3 \mathrm{mM} \mathrm{H}_{2}$ would have been generated. Hence the amount of 'lost' $\mathrm{H}_{2}$ to account for is in fact higher than was immediately apparent, at $\sim 5.4 \mathrm{mM} \mathrm{H}_{2}$.

Bottom water dissolved $\mathrm{O}_{2}$ and $\mathrm{NO}_{3}$ levels in the Caribbean Sea are $\sim 200 \mu \mathrm{mol} / \mathrm{kg}$ and $\sim 20 \mu \mathrm{mol} / \mathrm{kg}$ (JOYCE et al., 2001), and reduction of these species would be insufficient to account for the observed $\mathrm{H}_{2}$ depletion. Reduction of seawater $\mathrm{SO}_{4}$, which is plentiful in mixed fluids due to entrainment of seawater is a means of consuming $\mathrm{H}_{2}$ :

$$
\mathrm{SO}_{4}^{2-}{ }_{(a q)}+4 \mathrm{H}_{2(a q)}+2 \mathrm{H}_{(a q)}^{+}=\mathrm{H}_{2} \mathrm{~S}_{(a q)}+4 \mathrm{H}_{2} \mathrm{O}_{(a q)}
$$

To account for the $\mathrm{SO}_{4}$ budget, however, anhydrite precipitate must also be considered:

$$
\mathrm{Ca}^{2+}{ }_{(a q)}+\mathrm{SO}_{4}{ }^{2-}{ }_{(a q)}=\mathrm{CaSO}_{4(s)}
$$


Based on a $\mathrm{Ca}^{2+}$ loss of $1.6 \mathrm{mmol} / \mathrm{kg}, 1.6 \mathrm{mmol} / \mathrm{kg}$ of $\mathrm{SO}_{4}$ is attributable to anhydrite formation. This leaves a net $\sim 2.3 \mathrm{mmol} / \mathrm{kg} \mathrm{SO}_{4}$ that could have been lost to reduction by $\mathrm{H}_{2}$. Up to 9.2 $\mathrm{mmol} / \mathrm{L} \mathrm{H}_{2}$ could have been consumed by reduction of the net $\sim 2.3 \mathrm{mmol} / \mathrm{kg} \mathrm{SO}_{4}$ lost, which can more than account for the $4.8 \mathrm{mM} \mathrm{H}_{2}$ loss observed. However, the $\delta^{34} \mathrm{~S}_{\mathrm{H} 2 \mathrm{~S}}$ value determined on the Hot Chimlet \#1 fluid reflects only a minor contribution of seawater-derived sulfur, as this fluid is only very slighly more ${ }^{34}$ S-enriched than the endmember $\delta^{34} \mathrm{~S}_{\mathrm{H} 2 \mathrm{~S}}$ values (Table 1). If 2.6 $\mathrm{mM} \Sigma \mathrm{H}_{2} \mathrm{~S}$ were consumed by pyrite formation, and $2.3 \mathrm{mM} \Sigma \mathrm{H}_{2} \mathrm{~S}$ were generated by SO 4 reduction, a net loss of $0.3 \mathrm{mM} \Sigma \mathrm{H}_{2} \mathrm{~S}$ would be expected (or a small gain, if pyrrhotite instead of pyrite formed). Rather, the Piccard fluids have lost $1.5 \mathrm{mM} \Sigma \mathrm{H}_{2} \mathrm{~S}$. Therefore, there is insufficent gain in mixed fluid $\mathrm{\Sigma H}_{2} \mathrm{~S}$ contents to fully explain $\mathrm{H}_{2}$ losses by $\mathrm{SO}_{4}$ reduction. Although the sink for $\mathrm{H}_{2}$ is likely an abiotic process at Hot Chimlet, the nature of the reactions involved remains an open question, and may involve intermediate redox state sulfur species.

Similar to observations made at Von Damm in CHAPTER 2, Piccard mixed fluids also show large enrichments in $\mathrm{\Sigma HCOOH}$. Reducing conditions, coupled with the lower temperatures and higher $\mathrm{pH}$ conditions of a mixed fluid, provide a thermodynamic drive for the abiotic reduction of $\Sigma \mathrm{CO}_{2}$ by $\mathrm{H}_{2}$ to $\Sigma \mathrm{HCOOH}\left(\mathrm{CO}_{2}+\mathrm{H}_{2}=\mathrm{HCOOH}\right)$. The $\Sigma \mathrm{HCOOH}$ generated would consume up to $167 \mu \mathrm{mol} / \mathrm{kg} \mathrm{H}_{2}$ in the Piccard fluids. Although this represents a relatively small amount of the fluid $\mathrm{H}_{2}$ budget within the high $\mathrm{H}_{2}$ Piccard system, abiotic $\Sigma \mathrm{HCOOH}$ formation may consume a significant fraction of $\mathrm{H}_{2}$ present in mixing zones in lower- $\mathrm{H}_{2}$ basalthosted systems, and should be considered in tandem with biogenic processes, such as the microbial utilization of $\mathrm{H}_{2}$. That the abiotic generation of $\Sigma \mathrm{HCOOH}$ in hydrothermal fluid occurs in mixing zones in both the Piccard and Von Damm systems reinforces conclusions made in CHAPTER 2, namely that abiotic $\mathrm{\Sigma HCOOH}$ formation in subsurface mixing zones is consistent 
with thermodynamic equilibrium, and represents a sink for vent fluid $\Sigma \mathrm{CO}_{2}$ and $\mathrm{H}_{2}$.

Furthermore, widespread abiotic $\Sigma \mathrm{HCOOH}$ production in low temperature hydrothermal fluids carries implications for the microbial strategies of methanogens that can utilize $\Sigma \mathrm{HCOOH}$ for metabolic energy and/or a source of fixed carbon.

\subsection{The origin of hydrocarbons and helium in high-temperature and mixed fluids}

The origin of $\mathrm{CH}_{4}$ and longer chained $\left(\mathrm{C}_{2+}\right)$ hydrocarbons in basalt-hosted hydrothermal systems has been of interest since the discovery of hydrothermal systems. Several possible sources of $\mathrm{CH}_{4}$ and longer chained hydrocarbons in hot, black smoker hydrothermal fluids such as those at Piccard include: (1) thermal decomposition of particulate and dissolved organic carbon present in the starting seawater source fluid to $\mathrm{CH}_{4}$ and $\mathrm{C}_{2+}$ hydrocarbons, (2) degassing of mantle-derived $\mathrm{CH}_{4}$, in a process akin to degassing of ${ }^{3} \mathrm{He}$ (LUPTON and CRAIG, 1975), or (3) organic synthesis of $\mathrm{CH}_{4}$ and $\mathrm{C}_{2+}$ hydrocarbons from $\Sigma \mathrm{CO}_{2}$ and $\mathrm{H}_{2}$, either within magmatic volatile-rich fluid inclusions leached from the substrate undergoing alteration (see CHAPTER 2), or occurring during active hydrothermal fluid circulation in high- $\mathrm{H}_{2}$ systems (WELHAN, 1988).

The $\Sigma \mathrm{CO}_{2}$ and $\mathrm{CH}_{4}$ composition in Piccard fluids reflect chemical disequilibrium at measured temperatures, $\mathrm{H}_{2}$ abundance, and total dissolved carbon contents, indicating a decoupling of hydrocarbons and $\Sigma \mathrm{CO}_{2}$, or equilibrium at some other condition. Such chemical disequilibria have been observed in other basalt-hosted black smoker systems that contain lower dissolved $\mathrm{H}_{2}$ than Piccard, where $\mathrm{CH}_{4}$ excesses relative to equilibrium with $\Sigma \mathrm{CO}_{2}$ are ubiquitous, and where carbon isotope equilibration points to $\mathrm{CH}_{4}$ formation temperatures that are significantly greater than venting fluid temperatures (MCCOLLOM and SEEwALD, 2007;

ProskUROWSKI et al., 2008). At Piccard, endmember fluid $\mathrm{CH}_{4}$ contents are lower than 
predicted relative to fluid $\Sigma \mathrm{CO}_{2}$ based on equilibrium calculations at the $\mathrm{H}_{2}$ and temperature conditions of sampling. Piccard high temperature $\delta^{13} \mathrm{C}_{\mathrm{CH} 4}$ values are similar to other values observed at other axial basalt-hosted systems. Carbon isotope fractionation for ${ }^{13} \mathrm{C}$ between Beebe Vents 1, 3, and 5 and Beebe Woods $\Sigma \mathrm{CO}_{2}-\mathrm{CH}_{4}$ is $\sim 20 \%$, a value consistent with equilibrium at $400^{\circ} \mathrm{C}$ (HORITA, 2001), close to the measured fluid temperatures. That the fluids are consistent with isotopic, but not chemical equilibrium, may be coincidental.

Dissolved He at Piccard is consistent with a mantle source which could be derived either from magmatic volatile-rich fluid inclusions, as is postulated at Von Damm (CHAPTER 2 and CHAPTER 3), or from active magmatic degassing. Measured $\Sigma \mathrm{CO}_{2}{ }^{\beta} \mathrm{He}$ ratios of 5.45 to $6.43 \times$ $10^{8}$ that are just below the average value for $\Sigma \mathrm{CO}_{2} / 3 \mathrm{He}$ measured in mantle rocks $\left(1 \times 10^{9}\right)$ (MARTY and TOLSTIKHIN, 1998) support a mantle source for high temperature $\Sigma \mathrm{CO}_{2}$ (Table 5). Radiocarbon-dead ${ }^{14} \mathrm{C} \mathrm{CH}_{4}$ measurements also support a mantle source for $\mathrm{CH}_{4}$ (Table 4). Whether the apparently mantle-derived endmember $\mathrm{CH}_{4}$ at Piccard is sourced from direct degassing or leached from basalt remains an open question.

Longer chain alkanes in the Piccard endmember fluids, $\mathrm{C}_{2} \mathrm{H}_{6}, \mathrm{C}_{3} \mathrm{H}_{8}, \mathrm{n}-\mathrm{C}_{4} \mathrm{H}_{10}$, and i$\mathrm{C}_{4} \mathrm{H}_{10}$, are present in trace nanomolar abundances that are four to five orders of magnitude lower than endmember $\mathrm{CH}_{4}$ abundances. ${ }^{13} \mathrm{C}$ fractionation between $\mathrm{CH}_{4}-\mathrm{C}_{2} \mathrm{H}_{6}$ is negligible (Table 4), and is consistent with equilibrium at higher temperatures, $>430^{\circ} \mathrm{C}$, beyond the temperature for which equilibrium fractionation factors have been calculated (GALIMOv et al., 1972). High temperature $\mathrm{C}_{2+}$ abundances may be derived from an abiotic mantle origin. It is also possible that these $\mathrm{C}_{2+}$ alkanes are derived from thermogenesis of dissolved organic carbon and particulate inorganic carbon sourced from the starting seawater, which are estimated to be $\sim 40$ 
$\mu \mathrm{mol} / \mathrm{kg}$ and $0.1 \mu \mathrm{mol} / \mathrm{kg}$ in the deep Atlantic Ocean (DRUfFel et al., 1992; HANSELL AND CARLSON, 1998).

\subsubsection{Pyrolysis as a source for hydrocarbons in mixed fluids}

At Piccard, substantial enrichments in $\mathrm{CH}_{4}, \mathrm{C}_{2} \mathrm{H}_{6}, \mathrm{C}_{3} \mathrm{H}_{8}$, and $\Sigma \mathrm{C}_{4} \mathrm{H}_{10}$ are observed in all lower-temperature mixed fluids relative to conservative mixing trends between endmember fluids and seawater (Fig. 6). Several lines of evidence suggest that these enrichments in mixed fluids are the product of pyrolysis of immature organic material. These enrichments are most pronounced in the $149^{\circ} \mathrm{C}$ Hot Chimlet \#1 fluid. Relative to biogenic and abiotic mantle-derived hydrocarbons, which are dominated by $\mathrm{CH}_{4}$ and contain relatively lower abundances of longer chained $\mathrm{C}_{2+}$ hydrocarbons, thermogenic hydrocarbons generally contain substantially greater proportions of $\mathrm{C}_{2+}$ alkanes relative to $\mathrm{CH}_{4}$ and are characterized by lower $\mathrm{CH}_{4} / \mathrm{C}_{2+}$ ratios (Schoell, 1988). The Piccard endmember $\mathrm{CH}_{4} / \mathrm{C}_{2+}$ ratio is $\sim 6900$ (mol/mol). The Hot Chimlet \#1 fluid is characterized by a substantially lower $\mathrm{CH}_{4} / \mathrm{C}_{2+}$ ratio of 69 reflecting a large enrichment in $\mathrm{C}_{2+}$ relative to conservative mixing. These enrichments suggest a thermogenic origin for $\mathrm{CH}_{4}$ and $\mathrm{C}_{2+}$ in the Piccard mixed fluids.

Carbon isotopic analysis of the Hot Chimlet \#1 fluid also supports a thermogenic origin for the observed enrichment in mixed fluid n-alkanes. For $\mathrm{CH}_{4}$ and $\mathrm{C}_{2} \mathrm{H}_{6}$, the fluid was treated as a two-component mixture consisting of an endmember contribution (assumed conservative with $\mathrm{Mg}$ ) plus an additional source contributed during mixing. Isotope mass balance calculations yield a $\delta^{13} \mathrm{C}_{\mathrm{CH} 4}$ value of $-39.7 \%$ and a $\delta^{13} \mathrm{C}_{\mathrm{C} 2 \mathrm{H} 6}$ value of $-33.8 \%$ for the additional hydrocarbon source. The measured $\delta^{13} \mathrm{C}_{\mathrm{C} 3 \mathrm{H} 8}$ value of $-29.7 \%$ is assumed to reflect this additional source, due to a low relative contribution of endmember-derived $\mathrm{C}_{3} \mathrm{H}_{8}$. These $\delta^{13} \mathrm{C}$ values are more ${ }^{13} \mathrm{C}$ - 
depleted than the Piccard endmember values, and fall within the range of $-25 \%$ to $-50 \%$ expected for thermogenic hydrocarbons (SCHOELL, 1980). There is also progressive ${ }^{13} \mathrm{C}$ enrichment observed with increasing chain length, consistent with results from field studies of thermogenic hydrocarbons, kinetic models, and pyrolysis experiments (DES MARAIS et al., 1988; LORANT et al., 1998; RoONEY et al., 1995). A thermogenic source of hydrocarbons in Piccard mixed fluids is also supported by enrichments in dissolved $\mathrm{NH}_{4}$ and $\mathrm{CH}_{3} \mathrm{SH}$ that have been attributed to a putative thermogenic source (REEVES et al., 2014).

\section{SUMMARY}

At the recently discovered Piccard hydrothermal field, the deepest MOR vent field currently known, $\mathrm{Cl}, \mathrm{SiO}_{2}$, and $\mathrm{Ca}$ fluid chemistry indicates high pressure and high temperature $\left(>500^{\circ} \mathrm{C}\right)$ convective circulation of seawater-derived vent fluids. The high reaction temperatures, in particular, are thought to result in fluids characterized by extremely high $\mathrm{H}_{2}$ abundances. These findings expand the known compositional range of basalt-hosted deep-sea hydrothermal systems. Multiple sources of organic compounds are identified in the Piccard fluids, ranging from abiotic mantle-derived hydrocarbons in the high-temperature black smoker fluids, to the likely abiotic generation of formate and pyrolytic hydrocarbon inputs within mixed fluids. An additional abiotic $\mathrm{H}_{2}$ sink remains to be elucidated, however mixed fluid $\mathrm{H}_{2}$ depletions can be partially accounted for by abiotic reduction of inorganic $\mathrm{SO}_{4}$ and production of $\Sigma \mathrm{HCOOH}$. 


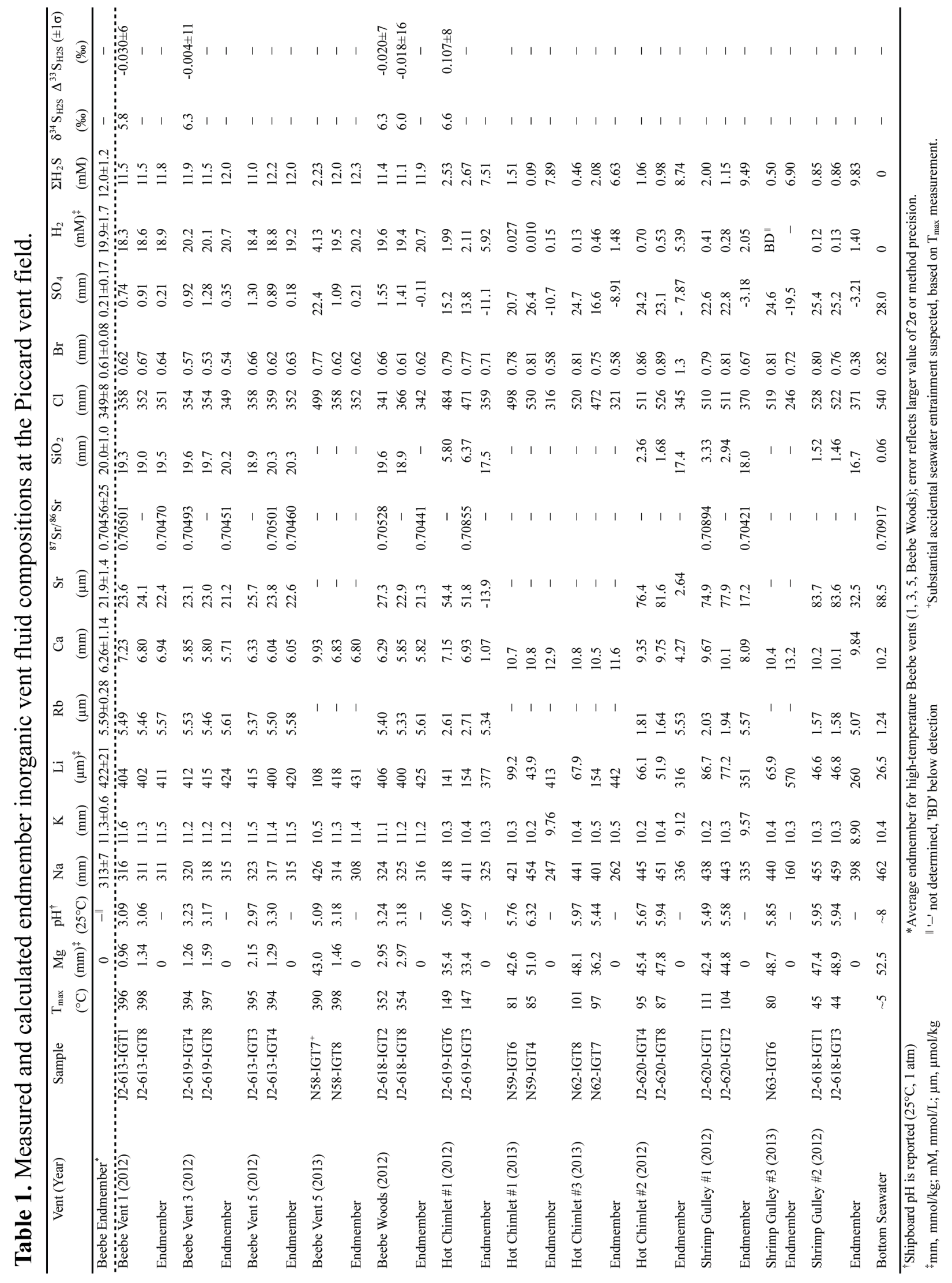


Table 2. Elemental ratios calculated from endmember fluid compositions at the Piccard vent field.

\begin{tabular}{|c|c|c|c|c|c|c|c|c|c|c|c|c|c|}
\hline Vent (Year) & $\begin{array}{c}\mathrm{T}_{\max } \\
{ }^{\circ} \mathrm{C}\end{array}$ & $\begin{array}{l}\mathrm{Mg}_{\text {min }} \\
\mathrm{mm}^{\ddagger}\end{array}$ & $\mathrm{Na} / \mathrm{Cl}$ & $\mathrm{K} / \mathrm{Cl}$ & $\mathrm{Ca} / \mathrm{Cl}$ & $\begin{array}{c}\mathrm{Sr} / \mathrm{Cl} \\
\left(\times 10^{-3}\right)\end{array}$ & $\begin{array}{c}\mathrm{Li} / \mathrm{Cl} \\
\left(\times 10^{-3}\right)\end{array}$ & $\begin{array}{c}\mathrm{Rb} / \mathrm{Cl} \\
\left(\times 10^{-3}\right)\end{array}$ & $\begin{array}{c}\mathrm{Br} / \mathrm{Cl} \\
\left(\times 10^{3}\right)\end{array}$ & $\begin{array}{c}\mathrm{Fe} / \mathrm{Cl} \\
\left(\times 10^{-3}\right)\end{array}$ & $\begin{array}{c}\mathrm{Mn} / \mathrm{Cl} \\
\left(\times 10^{-3}\right)\end{array}$ & $\mathrm{Fe} / \mathrm{Mn}$ & $\mathrm{Sr} / \mathrm{Ca}$ \\
\hline Beebe Vent 1(2012) & 398 & 0.96 & 0.89 & 0.033 & 0.020 & 0.064 & 1.2 & 0.016 & 1.8 & 19 & 1.6 & 12 & 3.2 \\
\hline Beebe Vent 3 (2012) & 397 & 1.26 & 0.90 & 0.032 & 0.016 & 0.061 & 1.2 & 0.016 & 1.6 & 19 & 1.6 & 12 & 3.7 \\
\hline Beebe Vent 5 (2012) & 395 & 1.29 & 0.90 & 0.032 & 0.017 & 0.064 & 1.2 & 0.016 & 1.8 & 18 & 1.6 & 12 & 3.7 \\
\hline Beebe Vent 5 (2013) & 398 & 1.46 & 0.88 & 0.032 & 0.019 & - & 1.2 & - & 1.8 & - & - & - & - \\
\hline Beebe Woods (2012) & 354 & 2.95 & 0.92 & 0.033 & 0.017 & 0.062 & 1.2 & 0.016 & 1.8 & 37 & 1.6 & 23 & 3.7 \\
\hline Hot Chimlet \#1 (2012) & 149 & 33.4 & 0.90 & 0.029 & 0.003 & -0.039 & 1.0 & 0.015 & 2.0 & - & - & - & -13 \\
\hline Hot Chimlet \#1 (2013) & 85 & 42.6 & 0.78 & 0.031 & 0.041 & - & 1.3 & - & 1.8 & - & - & - & - \\
\hline Hot Chimlet \#3 (2013) & 101 & 36.2 & 0.82 & 0.033 & 0.028 & - & 1.4 & - & 1.8 & - & - & - & - \\
\hline Hot Chimlet \#2 (2012) & 95 & 45.4 & 0.97 & 0.026 & 0.012 & 0.0076 & 0.92 & 0.016 & 3.7 & - & - & - & 0.62 \\
\hline Shrimp Gulley \#1 (2012) & 111 & 42.4 & 0.91 & 0.026 & 0.022 & 0.047 & 0.95 & 0.015 & 1.8 & - & - & - & 2.1 \\
\hline Shrimp Gulley \#3 (2013) & 80 & 48.7 & 0.65 & 0.042 & 0.054 & - & 2.3 & - & 1.6 & - & - & - & - \\
\hline Shrimp Gulley \#2 (2012) & 45 & 47.4 & 1.07 & 0.024 & 0.027 & 0.088 & 0.70 & 0.014 & 1.0 & - & - & - & 3.3 \\
\hline Bottom Seawater & $\sim 5$ & - & 0.86 & 0.019 & 0.019 & 0.16 & 0.049 & 0.0023 & 1.5 & $<0.00001$ & $<0.00001$ & - & 8.7 \\
\hline
\end{tabular}

${ }^{\ddagger} \mathrm{mm}, \mathrm{mmol} / \mathrm{kg}$

$\|$ '-' not determined. 
Table 3. Measured and calculated carbon species abundances in vent fluids at the Piccard vent field.

\begin{tabular}{|c|c|c|c|c|c|c|c|c|}
\hline Vent (Year) & Sample & $\begin{array}{l}\Sigma \mathrm{CO}_{2} \\
\mathrm{~mm}^{\ddagger}\end{array}$ & $\begin{array}{c}\Sigma \mathrm{HCOOH} \\
\mu \mathrm{m}\end{array}$ & $\begin{array}{c}\mathrm{CH}_{4} \\
\mu \mathrm{M}\end{array}$ & $\begin{array}{c}\mathrm{C}_{2} \mathrm{H}_{6} \\
\mathrm{~nm}\end{array}$ & $\begin{array}{c}\mathrm{C}_{3} \mathrm{H}_{8} \\
\mathrm{~nm}\end{array}$ & $\begin{array}{c}\mathrm{n}-\mathrm{C}_{4} \mathrm{H}_{10} \\
\mathrm{~nm}\end{array}$ & $\begin{array}{c}\mathrm{i}-\mathrm{C}_{4} \mathrm{H}_{10} \\
\mathrm{~nm}\end{array}$ \\
\hline Beebe Endmember $^{*}$ & & $25.7 \pm 1.3$ & - & $124 \pm 15$ & - & - & - & - \\
\hline \multirow[t]{2}{*}{ Beebe Vent $1(2012)$} & J2-613-IGT1 & 25.4 & $\mathrm{BD}$ & 110 & $=$ & $\because$ & 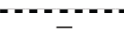 & $\overline{-}$ \\
\hline & J2-613-IGT8 & 25.6 & $\mathrm{BD}$ & 115 & - & - & - & - \\
\hline Endmember & & 26.0 & - & 115 & - & - & - & - \\
\hline \multirow[t]{2}{*}{ Beebe Vent 3 (2012) } & J2-619-IGT4 & 25.7 & $\mathrm{BD}$ & 120 & - & - & - & - \\
\hline & J2-619-IGT8 & 25.0 & $\mathrm{BD}$ & 120 & 10 & - & 1.2 & $\mathrm{BD}$ \\
\hline Endmember & & 26.0 & - & 123 & 11 & - & 1.2 & - \\
\hline \multirow[t]{2}{*}{ Beebe Vent 5 (2012) } & J2-613-IGT3 & 24.1 & $\mathrm{BD}$ & 117 & 15 & 5.3 & 2.3 & 1.2 \\
\hline & J2-613-IGT4 & 24.6 & $\mathrm{BD}$ & 114 & 14 & 9.4 & 2.8 & $\mathrm{BD}$ \\
\hline Endmember & & 25.1 & - & 120 & 15 & 7.6 & 2.6 & 1.3 \\
\hline \multirow[t]{2}{*}{ Beebe Vent 5 (2013) } & N58-IGT7 & - & $\mathrm{BD}$ & 28.3 & - & - & - & - \\
\hline & N58-IGT8 & - & $\mathrm{BD}$ & 130 & - & - & - & - \\
\hline Endmember & & - & - & 134 & - & - & - & - \\
\hline \multirow[t]{2}{*}{ Beebe Woods (2012) } & J2-618-IGT2 & 24.5 & 4.3 & 121 & 28 & 18 & 9.0 & 5.2 \\
\hline & J2-618-IGT8 & 24.7 & 4.8 & 120 & 26 & 13 & 5.4 & 1.2 \\
\hline Endmember & & 25.9 & 4.8 & 128 & 28 & 16 & 7.6 & 3.4 \\
\hline \multirow[t]{2}{*}{ Hot Chimlet \#1 (2012) } & J2-619-IGT6 & 9.09 & 54 & 52.5 & 43 & 28 & 9.0 & 9.7 \\
\hline & J2-619-IGT3 & 10.1 & 58 & 57.9 & 92 & 66 & 27 & 11 \\
\hline Endmember & & 23.6 & - & 160 & - & - & - & - \\
\hline \multirow[t]{2}{*}{ Hot Chimlet \#1 (2013) } & N59-IGT6 & - & 13 & 40.6 & 27 & 22 & 5.4 & 5.2 \\
\hline & N59-IGT4 & - & $\mathrm{BD}$ & 10.0 & - & - & - & - \\
\hline Endmember & & - & - & 216 & - & - & - & - \\
\hline \multirow[t]{2}{*}{ Hot Chimlet \#3 (2013) } & N62-IGT8 & - & 55 & 23.6 & - & - & - & - \\
\hline & N62-IGT7 & - & 167 & 65.9 & 36 & 28 & 7.3 & 7.7 \\
\hline Endmember & & - & - & 216 & - & - & - & - \\
\hline \multirow[t]{2}{*}{ Hot Chimlet \#2 (2012) } & J2-620-IGT4 & 4.89 & 16 & 22.3 & 17 & 11 & 4.3 & 3.4 \\
\hline & J2-620-IGT8 & 4.08 & 12 & 16.0 & 11 & 8.3 & 3.1 & $\mathrm{BD}$ \\
\hline Endmember & & 22.4 & - & 169 & - & - & - & - \\
\hline \multirow[t]{2}{*}{ Shrimp Gulley \#1 (2012) } & J2-620-IGT1 & 5.95 & 24 & 24.6 & 14 & 9.7 & 3.8 & 1.6 \\
\hline & $\mathrm{J} 2-620-\mathrm{IGT} 2$ & 5.56 & 18 & 21.0 & 12 & 7.3 & 2.7 & $\mathrm{BD}$ \\
\hline Endmember & & 22.9 & - & 134 & - & - & - & - \\
\hline Shrimp Gulley \#3 (2013) & N63-IGT6 & - & $\mathrm{BD}$ & 19.9 & - & - & - & - \\
\hline Endmember & & - & - & 274 & - & - & - & - \\
\hline \multirow[t]{2}{*}{ Shrimp Gulley \#2 (2012) } & J2-618-IGT1 & 3.39 & 9.4 & 11.0 & 5.1 & - & 1.6 & $\mathrm{BD}$ \\
\hline & J2-618-IGT3 & 3.64 & 8.8 & 11.1 & 5.1 & 4.0 & 1.8 & $\mathrm{BD}$ \\
\hline Endmember & & 17.1 & - & 128 & - & - & - & - \\
\hline Bottom Seawater & - & 2.21 & 0 & 0 & 0 & 0 & 0 & 0 \\
\hline
\end{tabular}

${ }^{\dagger} \mathrm{mm}, \mathrm{mmol} / \mathrm{kg} ; \mathrm{mM}, \mathrm{mmol} / \mathrm{L} ; \mu \mathrm{m}, \mu \mathrm{mol} / \mathrm{kg}$

*Average endmember for high-temperature Beebe vents

\| '-' not determined, 'BD' below detection

$(1,3,5$, Beebe Woods); error reflects larger value of $2 \sigma$ or method precision. 
Table 4. Measured carbon species $\delta^{13} \mathrm{C}$ and $\Delta{ }^{14} \mathrm{C}$ values in vent fluids at the Piccard vent field.

\begin{tabular}{|c|c|c|c|c|c|c|c|}
\hline Vent (Year) & Sample & $\begin{array}{c}\delta^{13} \mathrm{C}_{\mathrm{CO} 2} \\
\% 0 \\
\end{array}$ & $\begin{array}{c}\delta^{13} \mathrm{C}_{\mathrm{CH} 4} \\
\% \\
\%\end{array}$ & $\begin{array}{c}\delta^{13} \mathrm{C}_{\mathrm{C} 2 \mathrm{H} 6} \\
\% 0 \\
\end{array}$ & $\begin{array}{c}\delta^{13} \mathrm{C}_{\mathrm{C} 3 \mathrm{H} 8} \\
\% 0 \\
\end{array}$ & $\begin{array}{c}\text { Meas. } \Delta^{14} \mathrm{C}_{\mathrm{CO} 2} \\
\mathrm{~F}_{\text {modern }}\end{array}$ & $\begin{array}{c}\text { Corr. } \Delta^{14} \mathrm{C}_{\mathrm{CO} 2} \\
\mathrm{~F}_{\text {modern }}\end{array}$ \\
\hline \multirow[t]{2}{*}{ Beebe Vent 1 (2012) } & J2-613-IGT8 & -3.9 & -23.6 & - & - & $0.0100 \pm 3$ & $0.0085 \pm 7$ \\
\hline & J2-613-IGT1 & -3.8 & - & - & - & - & - \\
\hline \multirow[t]{2}{*}{ Beebe Vent 3 (2012) } & J2-619-IGT4 & -4.1 & - & - & - & - & - \\
\hline & J2-619-IGT8 & -4.3 & -23.8 & - & - & - & - \\
\hline \multirow[t]{2}{*}{ Beebe Vent 5 (2012) } & J2-613-IGT3 & -4.7 & - & - & - & - & - \\
\hline & J2-613-IGT4 & -4.8 & -24.3 & - & - & - & - \\
\hline Beebe Vent $1,3,5(2012)^{*}$ & $*$ & - & - & -24.9 & - & - & - \\
\hline \multirow[t]{2}{*}{ Beebe Woods (2012) } & J2-618-IGT2 & -4.0 & -23.7 & - & - & - & - \\
\hline & J2-618-IGT8 & -3.8 & - & - & - & - & - \\
\hline Beebe Woods $(2012)^{\dagger}$ & $\dagger$ & - & - & -24.4 & - & - & - \\
\hline \multirow[t]{2}{*}{ Hot Chimlet \#1 (2012) } & J2-619-IGT6 & -4.3 & -28.4 & -33.3 & -29.7 & $0.1501 \pm 14$ & $-0.0062 \pm 131$ \\
\hline & J2-619-IGT3 & -4.2 & -29.9 & -33.5 & -28.2 & $0.1336 \pm 10$ & $0.0015 \pm 110$ \\
\hline Hot Chimlet \#3 (2013) & N62-IGT7 & - & - & -36.9 & -29.2 & - & - \\
\hline \multirow[t]{2}{*}{ Hot Chimlet \#2 (2012) } & J2-620-IGT4 & -4.6 & -29.5 & - & - & - & - \\
\hline & J2-620-IGT8 & -5.7 & - & - & - & - & - \\
\hline \multirow[t]{2}{*}{ Shrimp Gulley \#1 (2012) } & J2-620-IGT1 & -4.0 & - & - & - & - & - \\
\hline & J2-620-IGT2 & -4.2 & - & - & - & - & - \\
\hline \multirow[t]{2}{*}{ Shrimp Gulley \#2 (2012) } & J2-618-IGT1 & -5.1 & - & - & - & - & - \\
\hline & J2-618-IGT3 & -5.6 & - & - & - & - & - \\
\hline
\end{tabular}


Table 5. He isotope abundances in vent fluids at the Piccard vent field.

\begin{tabular}{|c|c|c|c|c|c|c|}
\hline Vent (Year) & Sample & $\begin{array}{c}\text { Meas. }{ }^{3} \mathrm{He} /{ }^{4} \mathrm{He} \\
\mathrm{R} / \mathrm{Ra}\end{array}$ & $\begin{array}{c}\text { Meas. }{ }^{4} \mathrm{He} \\
\text { ccSTP/g }\end{array}$ & $\begin{array}{c}\text { Meas. }{ }^{4} \mathrm{He} \\
(\mu \mathrm{m})\end{array}$ & $\begin{array}{c}\text { Calc. }{ }^{3} \mathrm{He}^{*} \\
(\mu \mathrm{m})\end{array}$ & Meas. $\mathrm{C} /{ }^{3} \mathrm{He}$ \\
\hline Beebe Vent 1 (2012) & J2-613-IGT8 & $8.30 \pm 13$ & $8.89 \mathrm{E}-05$ & 3.63 & $3.99 \mathrm{E}-05$ & $6.43 \mathrm{E}+08$ \\
\hline Beebe Vent 5 (2012) & J2-613-IGT4 & $8.37 \pm 13$ & $9.51 \mathrm{E}-05$ & 3.89 & 4.44E-05 & $5.45 \mathrm{E}+08$ \\
\hline Beebe Woods (2012) & J2-618-IGT2 & $8.41 \pm 13$ & $5.49 \mathrm{E}-07 *$ & 0.0225 & $2.61 \mathrm{E}-07$ & $9.44 \mathrm{E}+10$ \\
\hline
\end{tabular}

*Although the ${ }^{3} \mathrm{He} /{ }^{4} \mathrm{He}$ ratio is consistent with a magmatic He source, ${ }^{4} \mathrm{He}$ abundances that are

much lower than the other Beebe Vents suggest that this sample may have leaked prior to analysis. 
Table 6. Measured and calculated endmember dissolved metal vent fluid compositions at the Piccard vent field.

\begin{tabular}{|c|c|c|c|c|c|c|c|c|c|c|}
\hline Vent (Year) & Sample & $\begin{array}{l}\mathrm{Mg} \\
\mathrm{mm}\end{array}$ & $\begin{array}{r}\mathrm{Al} \\
\mu \mathrm{m}\end{array}$ & $\begin{array}{c}\mathrm{Fe} \\
\mathrm{mm}\end{array}$ & $\begin{array}{l}\mathrm{Mn} \\
\mu \mathrm{m}\end{array}$ & $\begin{array}{l}\mathrm{Zn} \\
\mu \mathrm{m}\end{array}$ & $\begin{array}{c}\mathrm{Cu} \\
\mu \mathrm{m}\end{array}$ & $\begin{array}{l}\mathrm{Pb} \\
\mu \mathrm{m}\end{array}$ & $\begin{array}{l}\text { Co } \\
\mu \mathrm{m}\end{array}$ & $\begin{array}{l}\mathrm{Cd} \\
\mathrm{nm}\end{array}$ \\
\hline \multirow[t]{2}{*}{ Beebe Vent 1 (2012) } & J2-613-IGT1 & 0.963 & 7.1 & 6.8 & 549 & 53 & 197 & - & 0.95 & 77 \\
\hline & J2-613-IGT8 & 1.34 & 9.1 & 6.2 & 533 & 52 & 201 & - & 0.97 & 75 \\
\hline Endmember & & 0.0 & 8.3 & 6.6 & 553 & 54 & 203 & - & 0.98 & 78 \\
\hline \multirow[t]{2}{*}{ Beebe Vent 3 (2012) } & J2-619-IGT4 & 1.26 & 7.3 & 6.5 & 537 & 55 & 374 & 2.8 & 0.84 & 103 \\
\hline & J2-619-IGT8 & 1.59 & 6.0 & 6.5 & 546 & 16 & 83 & 0.45 & 1.3 & 80 \\
\hline Endmember & & 0.0 & 6.9 & 6.7 & 557 & 36 & 235 & 1.7 & 1.1 & 94 \\
\hline \multirow[t]{2}{*}{ Beebe Vent 5 (2012) } & J2-613-IGT3 & 2.15 & 5.4 & 6.1 & 534 & 80 & 130 & 0.021 & 0.93 & 82 \\
\hline & J2-613-IGT4 & 1.29 & 6.4 & 6.4 & 540 & 66 & 203 & 0.095 & 1.1 & 88 \\
\hline Endmember & & 0.0 & 6.1 & 6.5 & 555 & 75 & 172 & 0.094 & 1.0 & 88 \\
\hline \multirow[t]{2}{*}{ Beebe Woods (2012) } & J2-618-IGT2 & 2.95 & 6.7 & 13 & 525 & 35 & 616 & 0.31 & 17 & 50 \\
\hline & J2-618-IGT8 & 2.97 & 9.0 & 10 & 525 & 52 & 640 & 0.40 & 11 & 48 \\
\hline Endmember & & 0.0 & 8.3 & 13 & 556 & 46 & 666 & 0.40 & 15 & 52 \\
\hline \multirow[t]{2}{*}{ Hot Chimlet \#1 (2012) } & J2-619-IGT6 & 35.4 & 5.0 & 0.85 & 244 & 1.4 & 15 & 0.11 & 0.27 & 3.9 \\
\hline & J2-619-IGT3 & 33.4 & 3.8 & 0.15 & 270 & 0.047 & 0.38 & - & - & - \\
\hline \multirow[t]{2}{*}{ Hot Chimlet \#2 (2012) } & J2-620-IGT4 & 45.4 & 3.8 & 0.15 & 97 & 2.4 & 22 & 0.17 & 0.10 & 4.6 \\
\hline & J2-620-IGT8 & 47.8 & 4.3 & 0.16 & 66 & 2.5 & 14 & 0.10 & 0.17 & 3.0 \\
\hline \multirow[t]{2}{*}{ Shrimp Gulley \#1 (2012) } & J2-620-IGT1 & 42.4 & 8.4 & 1.9 & 114 & 5.2 & 21 & 0.30 & 0.19 & 7.5 \\
\hline & J2-620-IGT2 & 44.8 & 1.9 & 1.6 & 91 & 5.3 & 209 & 0.12 & 2.9 & 9.7 \\
\hline \multirow[t]{2}{*}{ Shrimp Gulley \#2 (2012) } & J2-618-IGT1 & 47.4 & 1.3 & 0.091 & 45 & 1.3 & 7.8 & 0.077 & 0.12 & 1.3 \\
\hline & J2-618-IGT3 & 48.9 & 4.7 & 0.11 & 44 & 6.3 & 40 & 0.49 & 0.029 & - \\
\hline Bottom Seawater & - & 52.5 & 0 & 0 & 0 & 0 & 0 & 0 & 0 & 0 \\
\hline
\end{tabular}

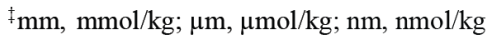

$\|$ ' - ' not determined 

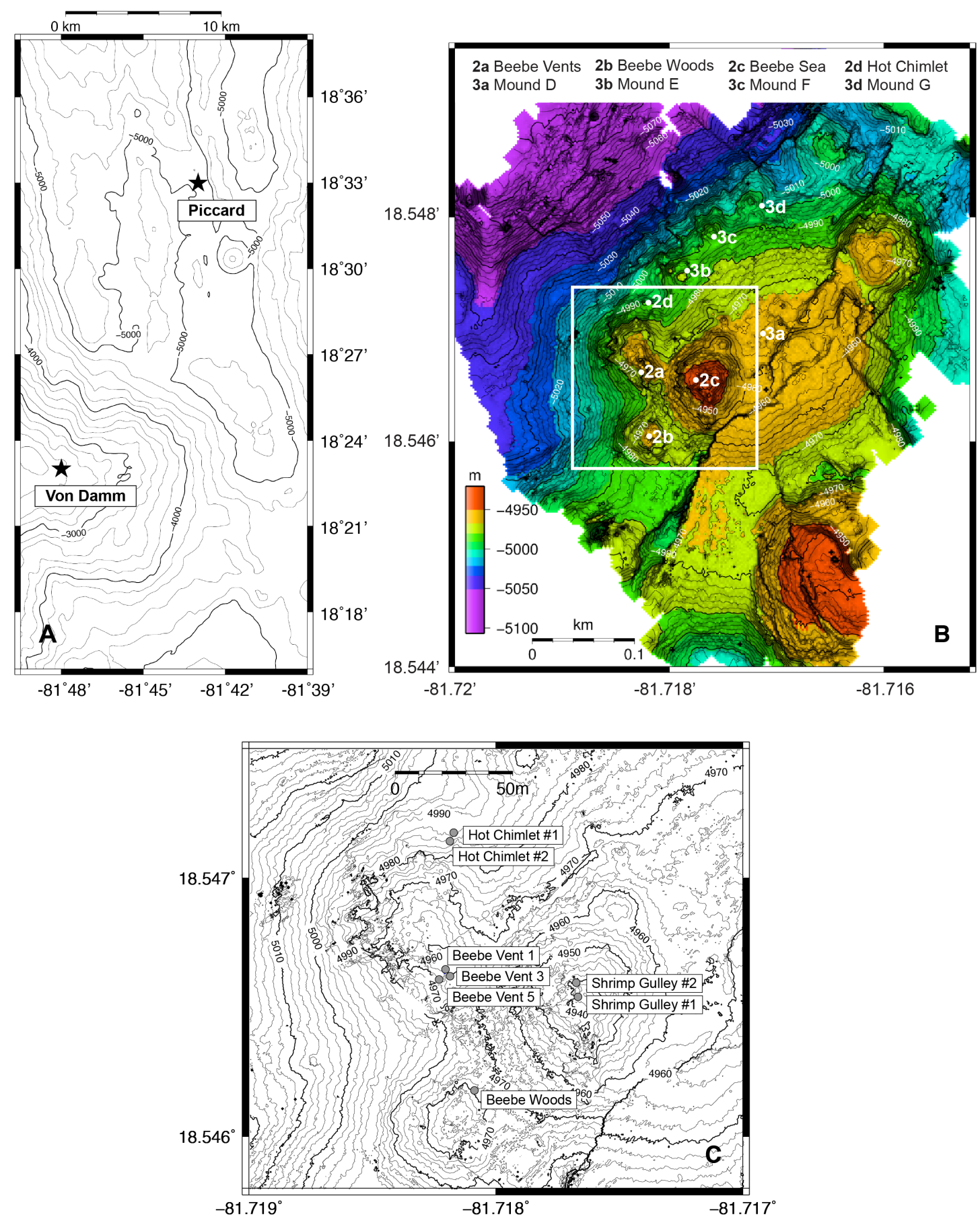

Figure 1. Map of the Mid-Cayman Rise (A), with the Von Damm and Piccard vent fields indicated by stars. Maps of the Piccard vent field (B and C), with actively venting and inactive sulfide mounds (Mounds D, E, F, G) identified (B, modified after KinsEY AND GERMAN, 2013) and inset from B with fluid sampling locations sampled in 2012 marked (C). 

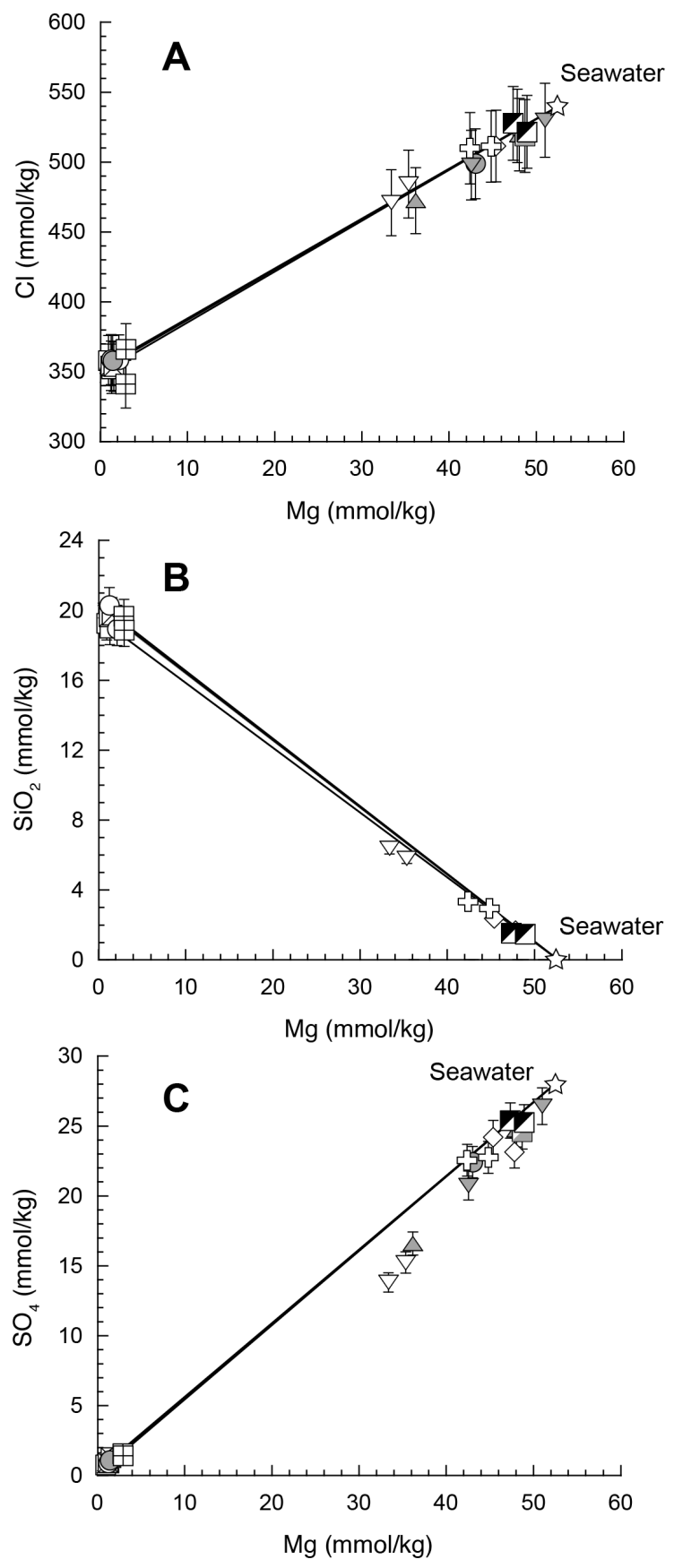

$\begin{array}{lll}\square \text { Beebe Vent } 1 \text { (2012) } & \boxplus \text { Beebe Woods (2012) } & \triangle \text { Hot Chimlet \#3 (2012) } \\ \square \text { Beebe Vent 3 (2012) } & \nabla \text { Hot Chimlet \#1 (2012) } & \text { ऍ Shrimp Gulley \#1 (2012) } \\ \bigcirc \text { Beebe Vent } 5 \text { (2012) } & \nabla \text { Hot Chimlet \#1 (2013) } & \square \text { Shrimp Gulley \#2 (2012) } \\ \bigcirc \text { Beebe Vent } 5 \text { (2013) } & \diamond \text { Hot Chimlet \#2 (2012) } & \square \text { Shrimp Gulley \#3 (2013) }\end{array}$

Figure 2. Measured $\mathrm{Mg}$ versus measured $\mathrm{Cl}(\mathrm{A}), \mathrm{Si}(\mathrm{B})$ and $\mathrm{SO}_{4}(\mathrm{C})$ for all fluids sampled at the Piccard vent field in 2012 (open symbols) and 2013 (shaded symbols). The extrapolated zero$\mathrm{Mg}$ endmembers for the high temperature fluids are indicated by the lines. $2 \sigma$ errors are shown. 

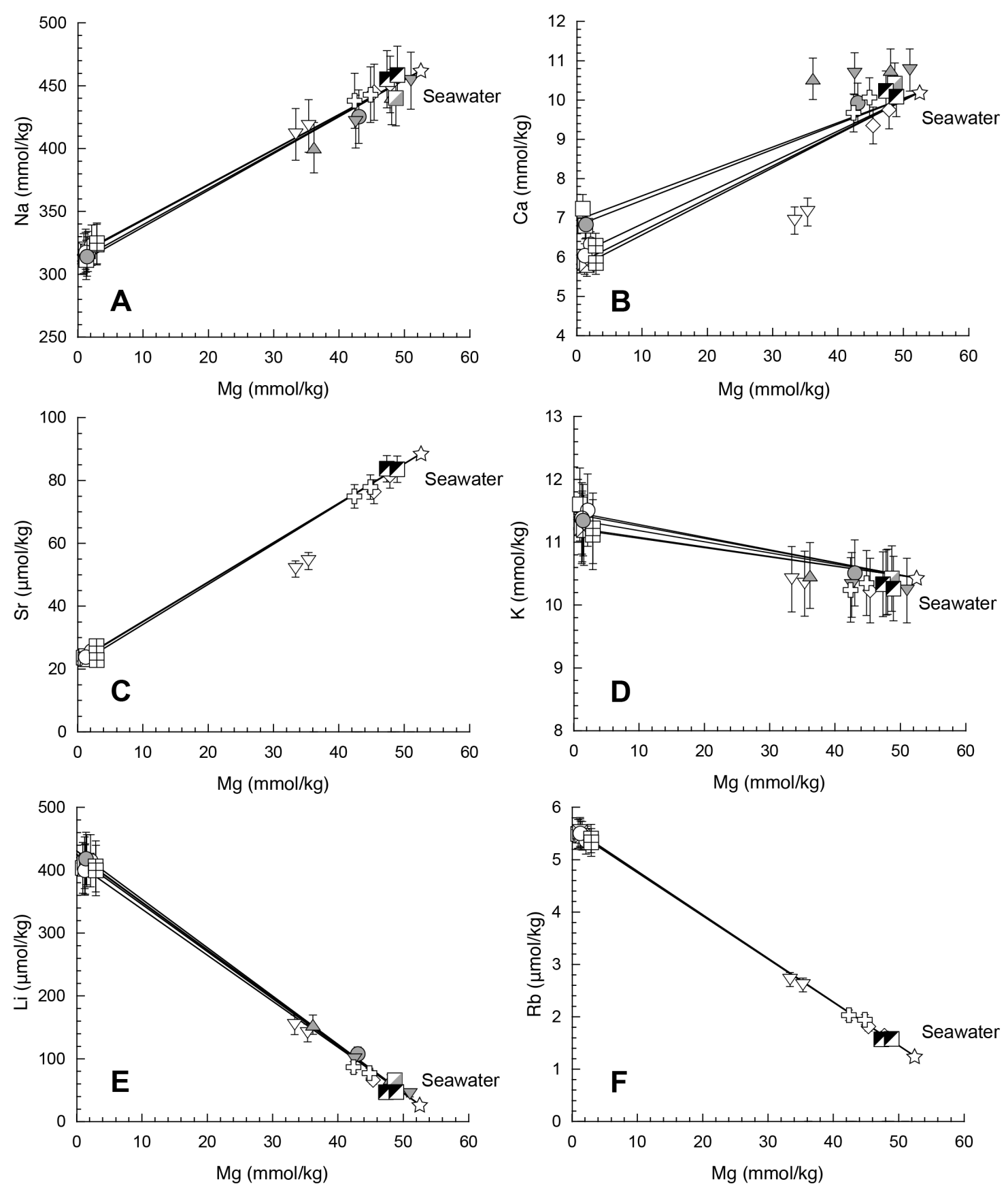

\begin{tabular}{|lll|}
\hline$\square$ Beebe Vent 1 (2012) & $\boxplus$ Beebe Woods (2012) & $\triangle$ Hot Chimlet \#3 (2012) \\
$\square$ Beebe Vent 3 (2012) & $\nabla$ Hot Chimlet \#1 (2012) & ß Shrimp Gulley \#1 (2012) \\
$\bigcirc$ Beebe Vent 5 (2012) & $\nabla$ Hot Chimlet \#1 (2013) & $\square$ Shrimp Gulley \#2 (2012) \\
$\bigcirc$ Beebe Vent 5 (2013) & $\diamond$ Hot Chimlet \#2 (2012) & $\square$ Shrimp Gulley \#3 (2013) \\
\hline
\end{tabular}

Figure 3. Measured $\mathrm{Mg}$ versus measured $\mathrm{Na}(\mathrm{A}), \mathrm{Ca}(\mathrm{B}), \mathrm{Sr}(\mathrm{C}), \mathrm{K}(\mathrm{D}), \mathrm{Li}(\mathrm{E})$ and $\mathrm{Rb}(\mathrm{F})$ for all fluids sampled at the Piccard vent field in 2012 (open symbols) and 2013 (shaded symbols). The extrapolated zero-Mg endmembers for the high temperature fluids are indicated by the lines. $2 \sigma$ errors are shown. 


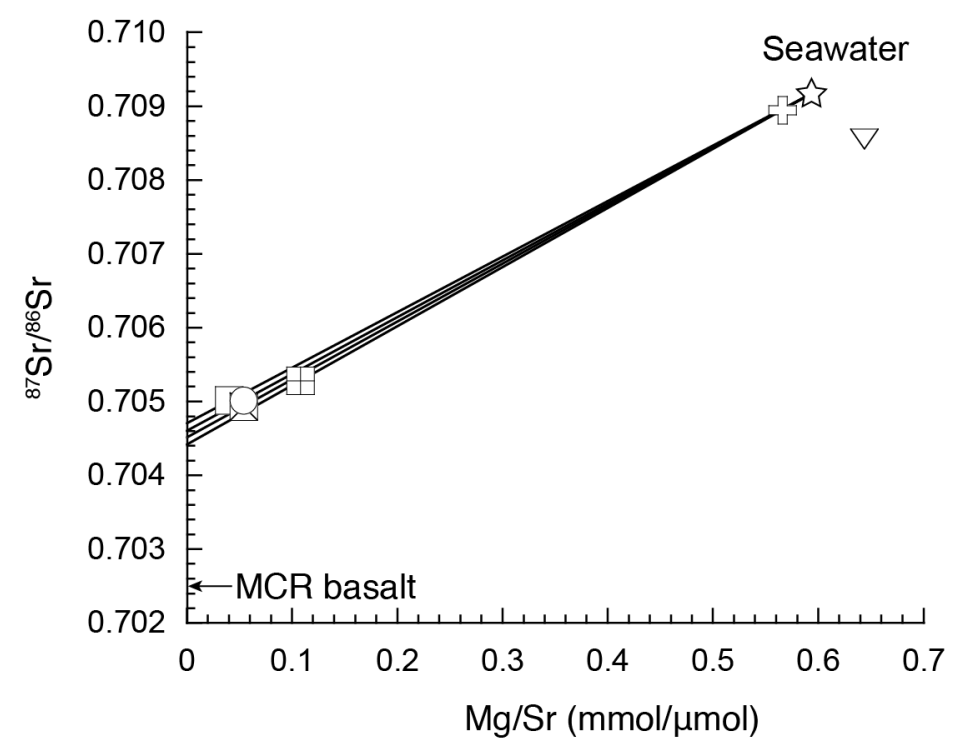

$$
\begin{array}{ll}
\square \text { Beebe Vent } 1 \text { (2012) } & \boxplus \text { Beebe Woods (2012) } \\
\square \text { Beebe Vent } 3(2012) & \nabla \text { Hot Chimlet \#1 (2012) } \\
\bigcirc \text { Beebe Vent } 5 \text { (2012) } & \text { ß Shrimp Gulley \#1 (2012) }
\end{array}
$$

Figure 4. Measured Mg/Sr vs. ${ }^{87} \mathrm{Sr} /{ }^{86} \mathrm{Sr}$ ratio for selected fluids at the Piccard vent field (ALBARÈDE ET AL., 1981). The extrapolated zero-Mg/Sr endmembers for the high temperature fluids are indicated by the lines. The average ${ }^{87} \mathrm{Sr} /{ }^{86} \mathrm{Sr}$ ratio determined in basalt from the MidCayman Rise is shown for comparison (COHEN and O'NIONS, 1982). 2 $\sigma$ errors are smaller than symbols. 


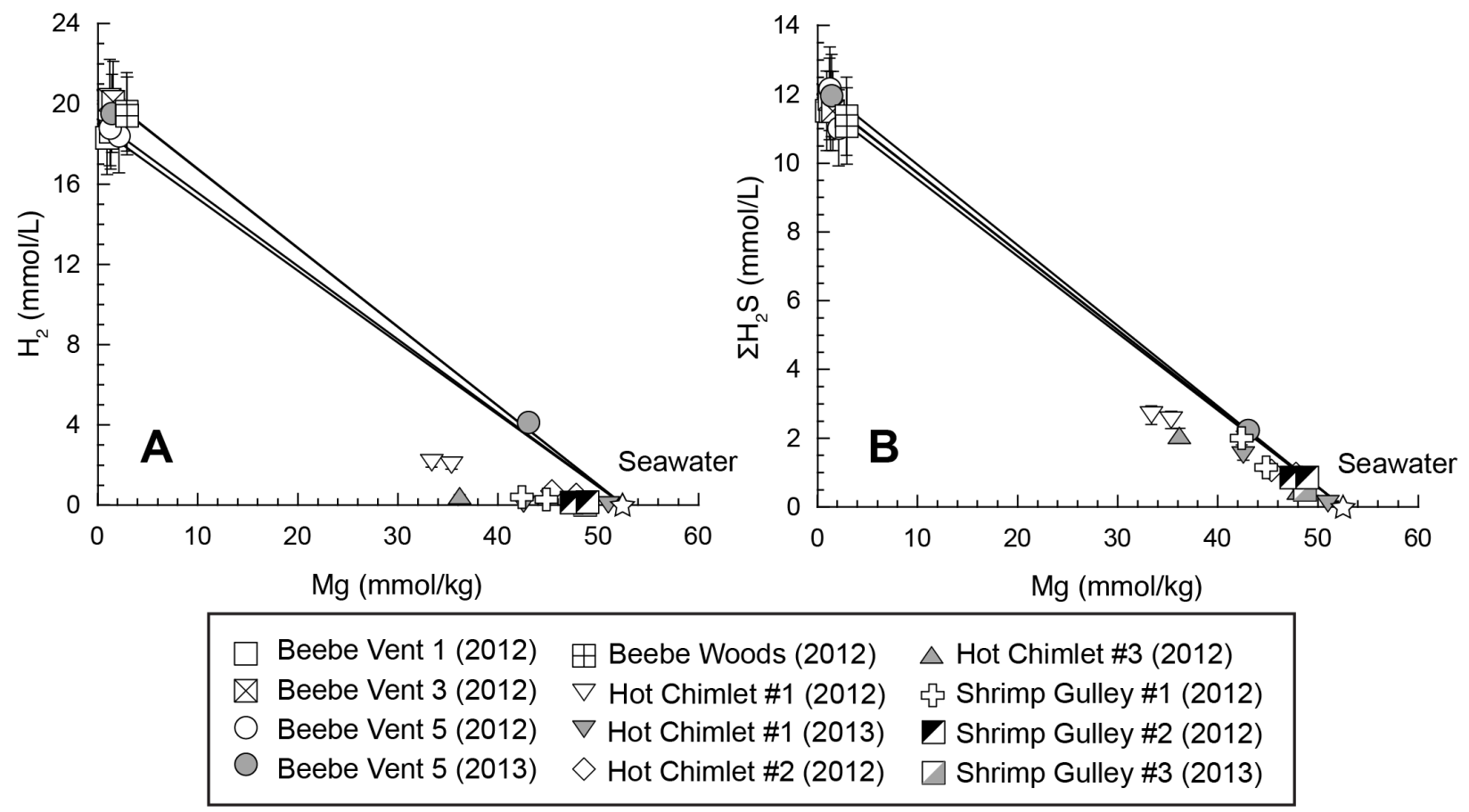

Figure 5. Measured $\mathrm{Mg}$ versus measured $\mathrm{H}_{2}$ (A) and $\Sigma \mathrm{H}_{2} \mathrm{~S}$ for all fluids sampled at the Piccard vent field in 2012 (open symbols) and 2013 (shaded symbols). The extrapolated zero-Mg endmembers for the high temperature fluids are indicated by the lines. $2 \sigma$ errors are shown. 

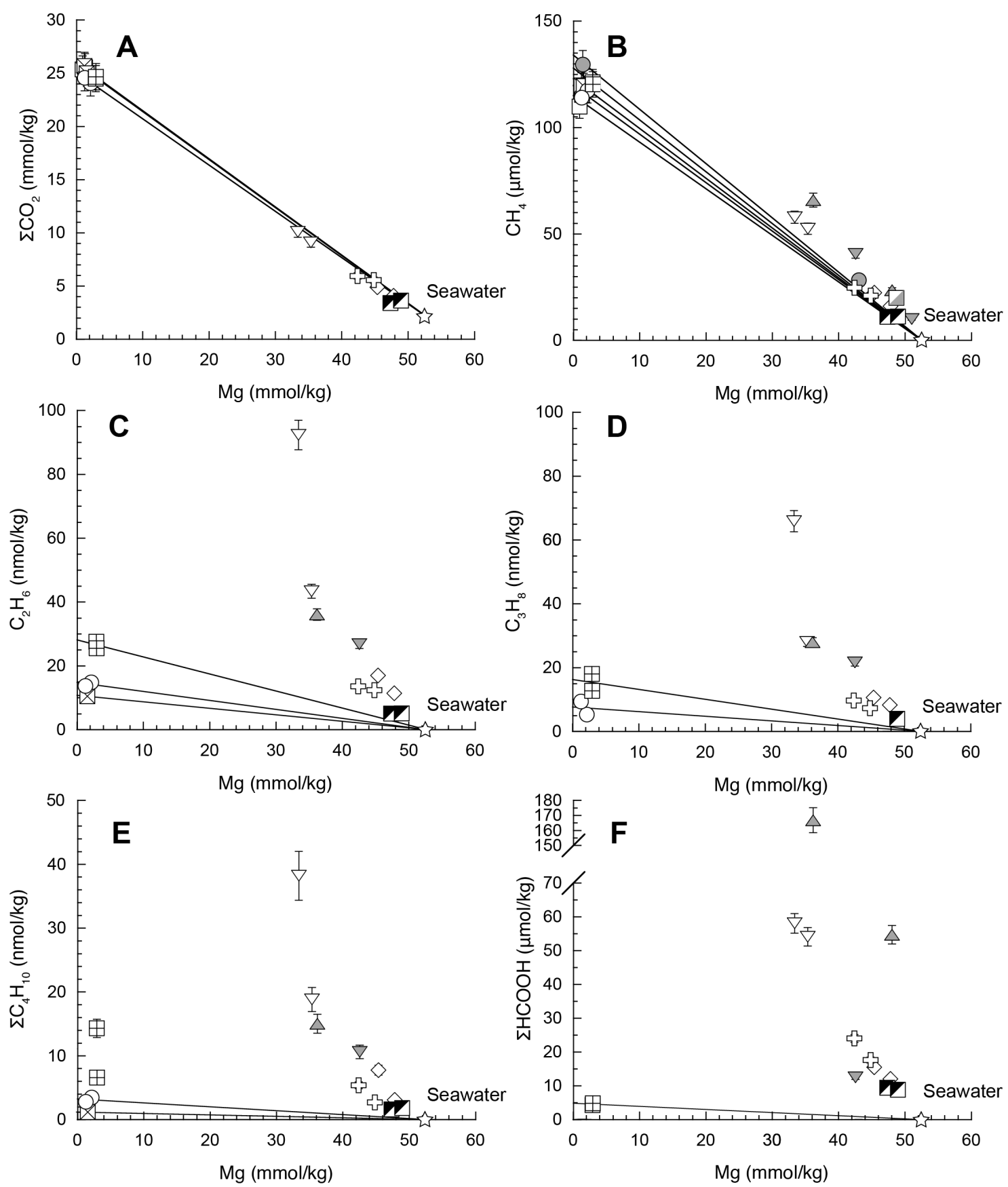

$\begin{array}{llll}\square \text { Beebe Vent } 1(2012) & \boxplus \text { Beebe Woods (2012) } & \triangle \text { Hot Chimlet \#3 (2012) } \\ \square \text { Beebe Vent } 3(2012) & \nabla \text { Hot Chimlet \#1 (2012) } & \text { Ґ Shrimp Gulley \#1 (2012) } \\ \bigcirc \text { Beebe Vent } 5(2012) & \nabla \text { Hot Chimlet \#1 (2013) } & \square \text { Shrimp Gulley \#2 (2012) } \\ \square \text { Beebe Vent } 5(2013) & \diamond \text { Hot Chimlet \#2 (2012) } & \square \text { Shrimp Gulley \#3 (2013) }\end{array}$

Figure 6. Measured $\mathrm{Mg}$ versus measured $\Sigma \mathrm{CO}_{2}(\mathrm{~A}), \mathrm{CH}_{4}(\mathrm{~B}), \mathrm{C}_{2} \mathrm{H}_{6}(\mathrm{C}), \mathrm{C}_{3} \mathrm{H}_{8}(\mathrm{D}), \Sigma_{4} \mathrm{H}_{10}(\mathrm{E})$ and $\mathrm{SHCOOH}(\mathrm{F})$ for all fluids sampled at the Piccard vent field in 2012 (open symbols) and 2013 (shaded symbols). The extrapolated zero-Mg endmembers for the high temperature fluids are indicated by the lines. $2 \sigma$ errors are shown. 

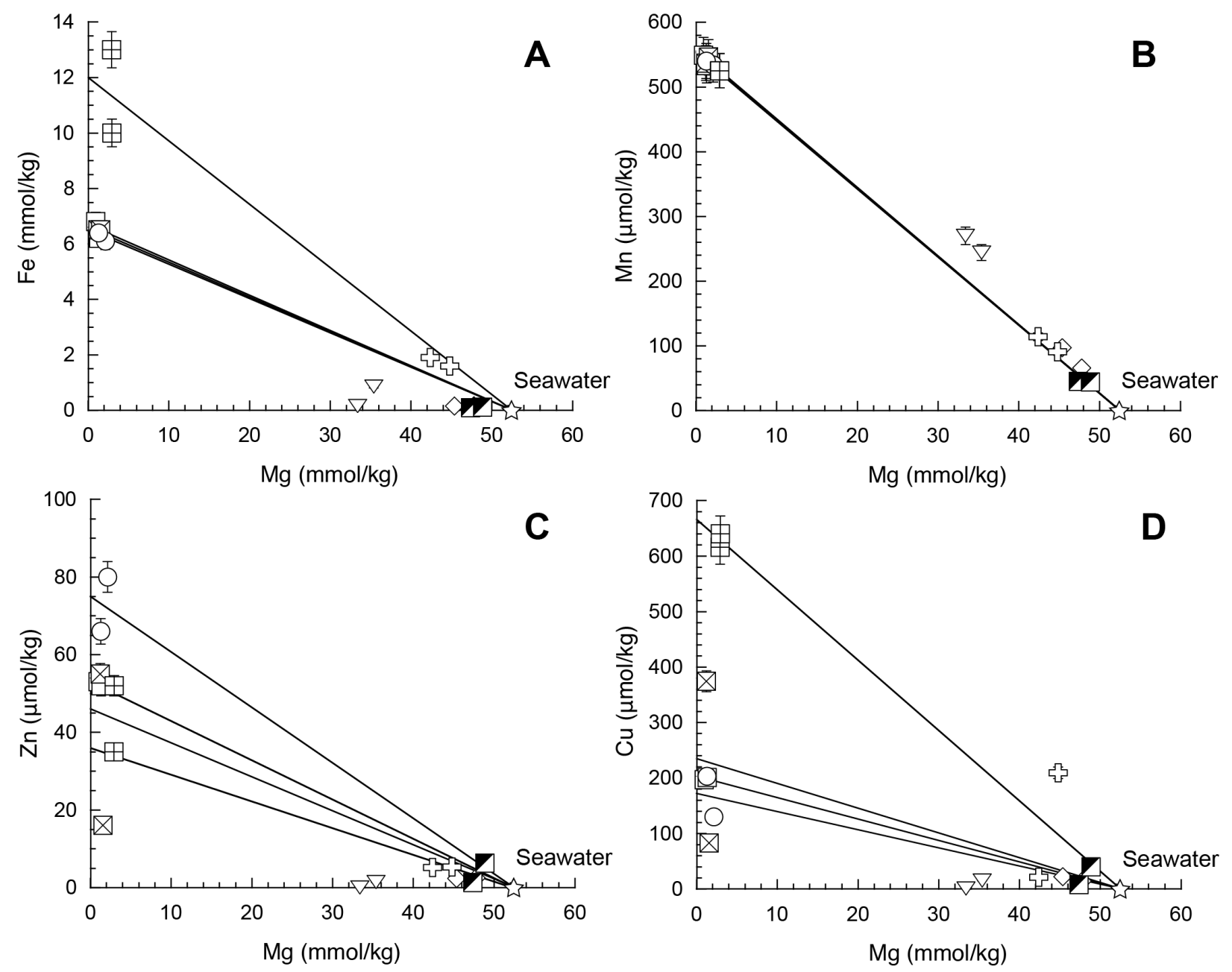

$\begin{array}{ll}\square \text { Beebe Vent } 1 \text { (2012) } & \nabla \text { Hot Chimlet \#1 (2012) } \\ \square \text { Beebe Vent } 3 \text { (2012) } & \diamond \text { Hot Chimlet \#2 (2012) } \\ \bigcirc \text { Beebe Vent } 5 \text { (2012) } & \wp \text { Shrimp Gulley \#1 (2012) } \\ \boxplus \text { Beebe Woods (2012) } & \square \text { Shrimp Gulley \#2 (2012) }\end{array}$

Figure 7. Measured Mg versus measured Fe (A), Mn (B), Zn (C) and Cu (D) for fluids sampled at the Piccard vent field in 2012. The extrapolated zero-Mg endmembers for the high temperature fluids are indicated by the lines. $2 \sigma$ errors are shown. 

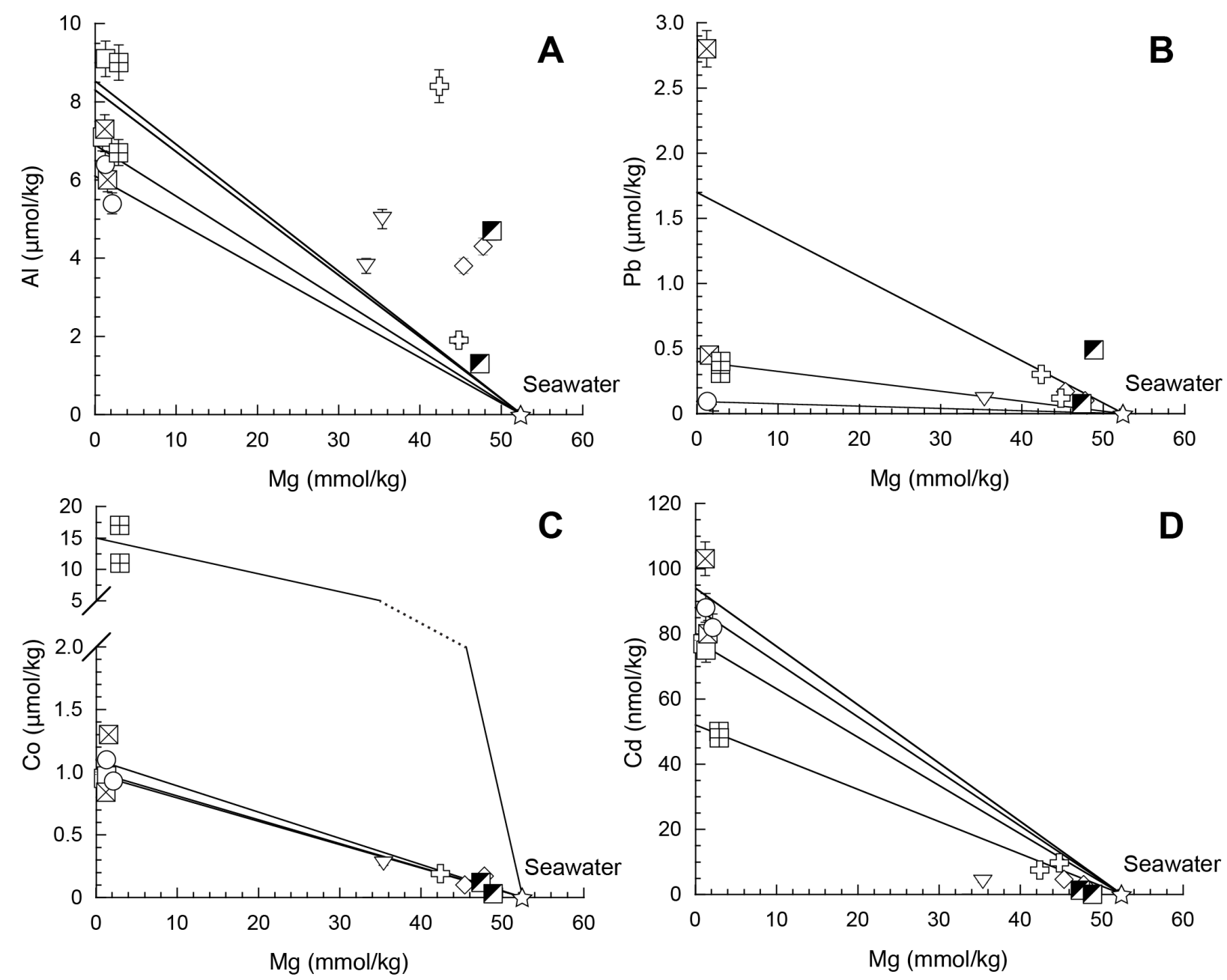

$\square$ Beebe Vent 1 (2012) $\nabla$ Hot Chimlet \#1 (2012)

$\triangle$ Beebe Vent 3 (2012) $\diamond$ Hot Chimlet \#2 (2012)

$\bigcirc$ Beebe Vent 5 (2012) § Shrimp Gulley \#1 (2012)

$\boxplus$ Beebe Woods (2012) \ Shrimp Gulley \#2 (2012)

Figure 8. Measured $\mathrm{Mg}$ versus measured $\mathrm{Al}(\mathrm{A}), \mathrm{Pb}(\mathrm{B}), \mathrm{Co}(\mathrm{C})$ and $\mathrm{Cd}(\mathrm{D})$ for fluids sampled at the Piccard vent field in 2012. The extrapolated zero-Mg endmembers for the high temperature fluids are indicated by the lines. $2 \sigma$ errors are shown. 

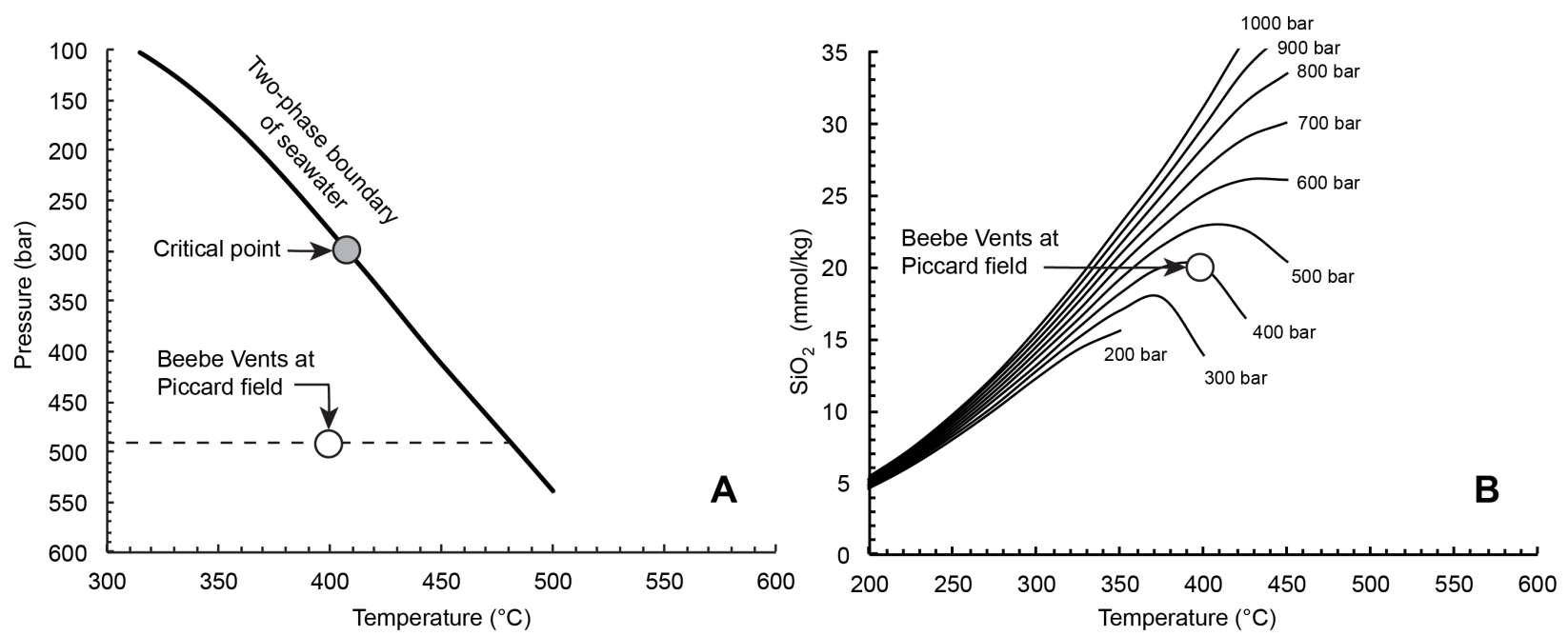

Figure 9. Plot of maximum sampled temperature and pressure conditions at the Piccard vent field (A). The curve represents the two-phase boundary of seawater (from BISCHOFF AND RosenbaUer, 1985), and the dashed line represents seafloor pressure at Piccard. Plot of endmember $\mathrm{SiO}_{2}$ content of the Beebe Vents 1, 3, 5 endmember fluid (B). Curves represent quartz saturation in seawater as a function of temperature and pressure (VON DAMM et al., 1991). 


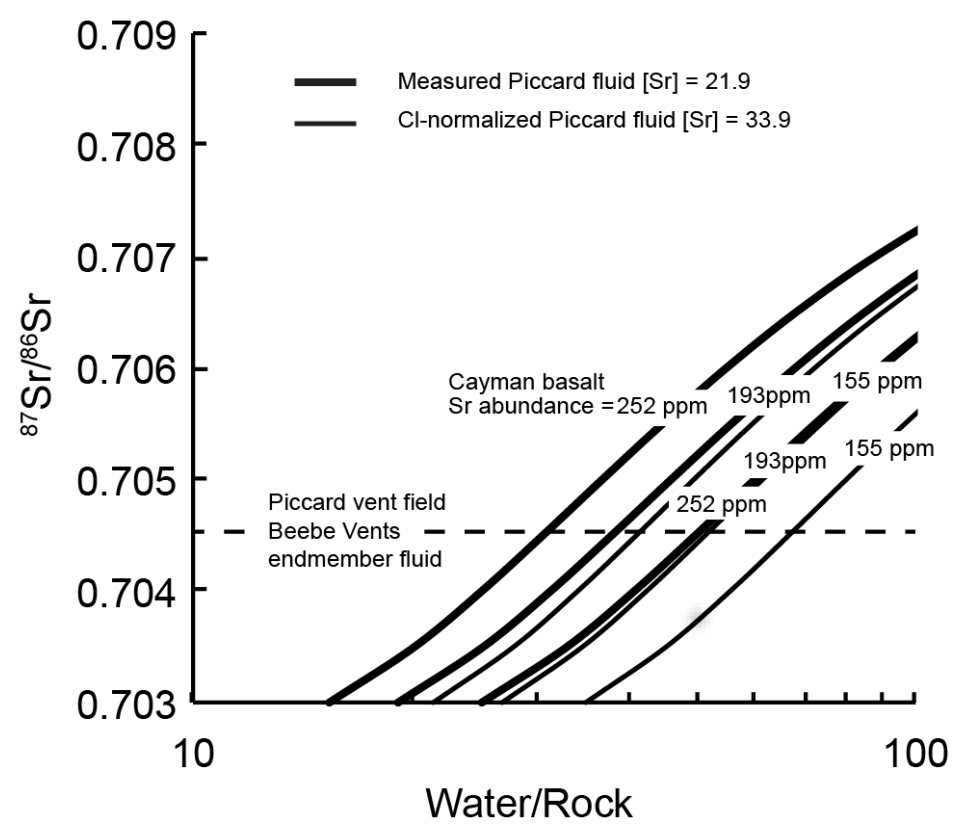

Figure 10. Curved lines indicate estimated $\mathrm{w} / \mathrm{r}$ mass ratios as a function of the fluid $\mathrm{Sr}$ isotope content and bulk $\mathrm{Sr}$ abundance in the Mid-Cayman Rise basalt protolith (COHEN and O'NIONS, 1982; ElthON et al., 1995). At Piccard, dissolved Sr abundances and ${ }^{87} \mathrm{Sr} /{ }^{86} \mathrm{Sr}$ ratios in the Beebe Vents endmember fluid indicate a w/r mass ratio between 20 and 60 . This variability is due to variation of bulk $\mathrm{Sr}$ in the basalt, which can range from 155 to $252 \mathrm{ppm}$, and averages 193 ppm, and variation in measured versus Cl-normalized endmember fluid $\mathrm{Sr}$ abundance. 


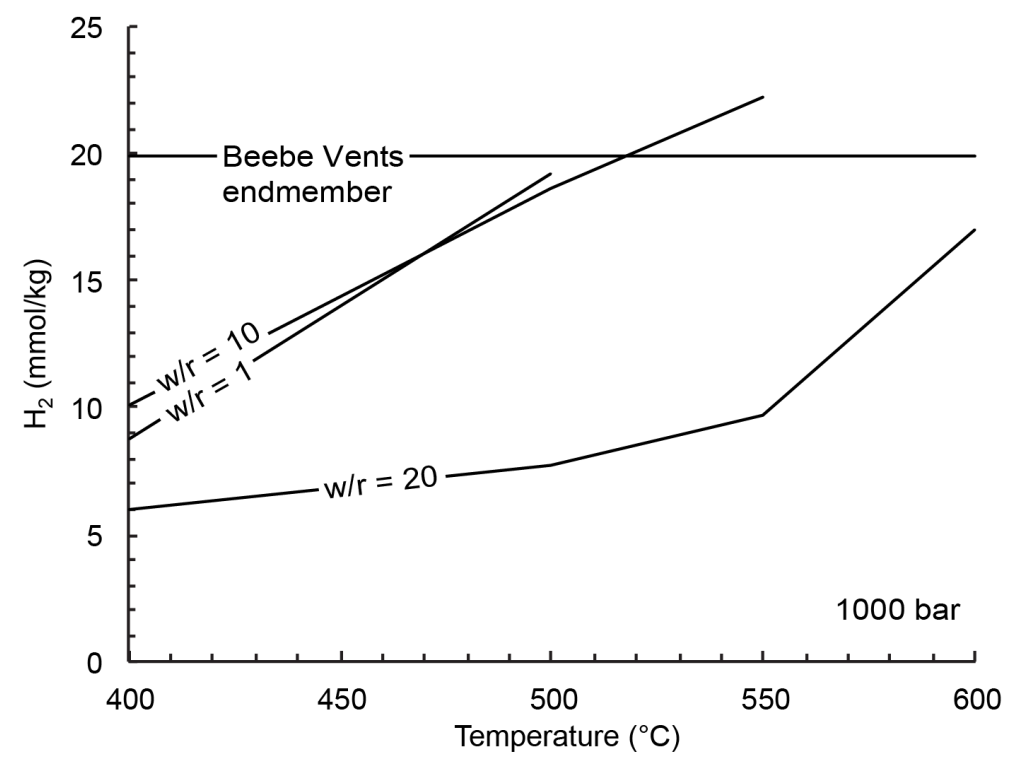

Figure 11. Modeled equilibrium fluid $\mathrm{H}_{2}$ contents as a function of temperature and water/rock $(\mathrm{w} / \mathrm{r})$ ratio at 1000 bar. Thermodynamic equilibrium model conditions are as described in the text. 


\section{APPENDiX}

Metal concentrations and dissolved $\mathrm{Mg}, \mathrm{Rb}, \mathrm{Sr}$, and $\mathrm{SiO}_{2}$ species were determined with inductively-coupled plasma mass spectrometry using a ThermoElectron Element 2 instrument at WHOI. Dissolved species were analyzed on filtered dissolved samples only (Table 1), while metals were determined separately on dissolved, filter, and dregs fractions (Table A1, Table A2, and Table A3). Masses analyzed included ${ }^{25} \mathrm{Mg},{ }^{59} \mathrm{Co},{ }^{85} \mathrm{Rb},{ }^{88} \mathrm{Sr},{ }^{114} \mathrm{Cd},{ }^{208} \mathrm{~Pb}$, (low resolution) and ${ }^{27} \mathrm{Al},{ }^{28} \mathrm{Si},{ }^{56} \mathrm{Fe},{ }^{66} \mathrm{Zn},{ }^{65} \mathrm{Cu}$ (medium resolution) on 5000x diluted aliquots for the dissolved fraction. Masses analyzed included ${ }^{27} \mathrm{Al},{ }^{28} \mathrm{Si},{ }^{55} \mathrm{Mn},{ }^{56} \mathrm{Fe},{ }^{66} \mathrm{Zn},{ }^{65} \mathrm{Cu}$ (medium resolution) on undiluted, 100x, 1000x, and 10,000x diluted aliquots for the dissolved, dregs, and filter fractions (as needed for each element).

Multi-element 5 point standards ( $0.2 \mathrm{ppb}, 1 \mathrm{ppb}, 10 \mathrm{ppb}, 100 \mathrm{ppb}, 500 \mathrm{ppb}$ ) were prepared in $5 \mathrm{wt} \%$ Optima $\mathrm{HNO}_{3}$ using Specpure ${ }^{\circledR}$ certified stock solutions. Three sets of standards were prepared, including one set in Milli-Q water and two sets that were matrix matched to the $100 \mathrm{x}$ and $1000 \mathrm{x}$ diluted aliquots using $\mathrm{NaCl}$ (i.e. $\mathrm{Cl}=6 \mathrm{mmol} / \mathrm{kg}$ and 0.6 $\mathrm{mmol} / \mathrm{kg}$, respectively). All samples and standards were spiked to $1 \mathrm{ppb}$ with ${ }^{45} \mathrm{Sc},{ }^{115} \mathrm{In}$, and ${ }^{209} \mathrm{Bi}$ and the intensity of elemental signals were normalized to those of ${ }^{45} \mathrm{Sc},{ }^{115} \mathrm{In}$, and ${ }^{209} \mathrm{Bi}$ in low or medium resolution (whichever spike was nearest in mass to the isotope measured) throughout the course of the run. Ambient $2300 \mathrm{~m}$ bottom seawater collected from a Niskin bottle on the CTD rosette was analyzed as an unknown sample. A working blank was collected for each of the three fractions, and samples were blank-corrected during offline processing. The detection limit for each species is defined as $50 \%$ of the sum of the blank signal $+0.2 \mathrm{ppb}$ standard signal. 
Table A1. Measured metal concentrations in the 'dissolved' fraction of Piccard fluids.

\begin{tabular}{|c|c|c|c|c|c|c|c|c|c|c|}
\hline Vent (Year) & Sample & $\begin{array}{c}\mathrm{Mg} \\
\mathrm{mm}^{\dagger}\end{array}$ & $\begin{array}{c}\mathrm{Al} \\
\mu \mathrm{m}^{\dagger}\end{array}$ & $\begin{array}{l}\mathrm{Mn} \\
\mu \mathrm{m}\end{array}$ & $\begin{array}{l}\mathrm{Fe} \\
\mu \mathrm{m}\end{array}$ & $\begin{array}{l}\mathrm{Zn} \\
\mu \mathrm{m}\end{array}$ & $\begin{array}{l}\mathrm{Cu} \\
\mu \mathrm{m}\end{array}$ & $\begin{array}{l}\mathrm{Pb} \\
\mu \mathrm{m}\end{array}$ & $\begin{array}{l}\text { Co } \\
\mu \mathrm{m}\end{array}$ & $\begin{array}{r}\mathrm{Cd} \\
\mu \mathrm{m} \\
\end{array}$ \\
\hline J2-613-IGT1 & Beebe Vent 1 (2012) & 0.96 & 5.6 & 544 & 6136 & 2.5 & 0.81 & $\mathrm{BD}$ & 0.00016 & $\mathrm{BD}$ \\
\hline J2-613-IGT8 & Beebe Vent 1 (2012) & 1.34 & 9.0 & 530 & 5877 & 1.1 & $\mathrm{BD}$ & $\mathrm{BD}$ & 0.000085 & $\mathrm{BD}$ \\
\hline J2-619-IGT4 & Beebe Vent 3 (2012) & 1.26 & 5.6 & 535 & 6001 & 0.13 & $\mathrm{BD}$ & $\mathrm{BD}$ & 0.000079 & $\mathrm{BD}$ \\
\hline J2-619-IGT8 & Beebe Vent 3 (2012) & 1.59 & 6.0 & 541 & 5968 & 12 & 22 & 0.33 & 0.000090 & BD \\
\hline J2-613-IGT3 & Beebe Vent 5 (2012) & 2.15 & 5.4 & 532 & 5748 & 1.2 & $\mathrm{BD}$ & 0.021 & 0.000038 & $\mathrm{BD}$ \\
\hline J2-613-IGT4 & Beebe Vent 5 (2012) & 1.29 & 6.3 & 534 & 6083 & 16 & 40 & 0.095 & 0.00010 & $\mathrm{BD}$ \\
\hline J2-618-IGT2 & Beebe Woods (2012) & 2.95 & 5.4 & 519 & 5656 & 0.15 & BD & $\mathrm{BD}$ & BD & $\mathrm{BD}$ \\
\hline J2-618-IGT8 & Beebe Woods (2012) & 2.97 & 5.7 & 518 & 5614 & 22 & $\mathrm{BD}$ & 0.072 & $\mathrm{BD}$ & $\mathrm{BD}$ \\
\hline J2-619-IGT6 & Hot Chimlet \#1 (2012) & 35.4 & 1.3 & 241 & 122 & 0.17 & $\mathrm{BD}$ & $\mathrm{BD}$ & $\mathrm{BD}$ & $\mathrm{BD}$ \\
\hline J2-619-IGT3 & Hot Chimlet \#1 (2012) & 33.4 & 3.3 & 268 & 100 & $\mathrm{BD}$ & BD & BD & BD & BD \\
\hline J2-620-IGT4 & Hot Chimlet \#2 (2012) & 45.4 & 1.9 & 96 & 42 & $\mathrm{BD}$ & $\mathrm{BD}$ & $\mathrm{BD}$ & $\mathrm{BD}$ & $\mathrm{BD}$ \\
\hline J2-620-IGT8 & Hot Chimlet \#2 (2012) & 47.8 & 0.39 & 65 & 31 & 0.29 & $\mathrm{BD}$ & $\mathrm{BD}$ & $\mathrm{BD}$ & $\mathrm{BD}$ \\
\hline J2-620-IGT1 & Shrimp Gulley \#1 (2012) & 42.4 & 0.46 & 101 & 40 & 1.0 & $\mathrm{BD}$ & BD & BD & $\mathrm{BD}$ \\
\hline J2-620-IGT2 & Shrimp Gulley \#1 (2012) & 44.8 & $\mathrm{BD}^{\ddagger}$ & 88 & 52 & 0.11 & $\mathrm{BD}$ & $\mathrm{BD}$ & $\mathrm{BD}$ & $\mathrm{BD}$ \\
\hline J2-618-IGT1 & Shrimp Gulley \#2 (2012) & 47.4 & 0.33 & 44 & 26 & 0.16 & $\mathrm{BD}$ & $\mathrm{BD}$ & $\mathrm{BD}$ & $\mathrm{BD}$ \\
\hline J2-618-IGT3 & Shrimp Gulley \#2 (2012) & 48.9 & 3.4 & 43 & 24 & 1.9 & $\mathrm{BD}$ & $\mathrm{BD}$ & $\mathrm{BD}$ & $\mathrm{BD}$ \\
\hline
\end{tabular}

${ }^{\dagger} \mathrm{mm}, \mathrm{mmol} / \mathrm{kg} ; \mu \mathrm{m}, \mu \mathrm{mol} / \mathrm{kg}$

'BD' below detection limit of the method 
Table A2. Measured metal concentrations in the 'filter' fraction of Piccard fluids.

\begin{tabular}{|c|c|c|c|c|c|c|c|c|c|c|}
\hline Vent (Year) & Sample & $\begin{array}{c}\mathrm{Mg} \\
\mathrm{mm}^{\dagger}\end{array}$ & $\begin{array}{c}\mathrm{Al} \\
\mu \mathrm{m}^{\dagger}\end{array}$ & $\begin{array}{l}\mathrm{Mn} \\
\mu \mathrm{m}\end{array}$ & $\begin{array}{l}\mathrm{Fe} \\
\mu \mathrm{m}\end{array}$ & $\begin{array}{l}\mathrm{Zn} \\
\mu \mathrm{m}\end{array}$ & $\begin{array}{l}\mathrm{Cu} \\
\mu \mathrm{m}\end{array}$ & $\begin{array}{l}\mathrm{Pb} \\
\mu \mathrm{m}\end{array}$ & $\begin{array}{l}\text { Co } \\
\mu \mathrm{m}\end{array}$ & $\begin{array}{l}\mathrm{Cd} \\
\mu \mathrm{m}\end{array}$ \\
\hline J2-613-IGT1 & Beebe Vent 1 (2012) & 0.96 & 1.5 & 3.7 & 49 & 1.7 & 9.1 & BD & 0.024 & 0.0043 \\
\hline J2-613-IGT8 & Beebe Vent 1 (2012) & 1.34 & 0.051 & 1.9 & 27 & 0.70 & 3.4 & $\mathrm{BD}$ & 0.010 & 0.0018 \\
\hline J2-619-IGT4 & Beebe Vent 3 (2012) & 1.26 & $\mathrm{BD}^{\ddagger}$ & $-\ddagger$ & 52 & - & 27 & 0.11 & - & - \\
\hline J2-619-IGT8 & Beebe Vent 3 (2012) & 1.59 & 0.027 & 4.2 & 70 & 2.7 & 11 & 0.12 & 0.066 & 0.0056 \\
\hline J2-613-IGT3 & Beebe Vent 5 (2012) & 2.15 & 0.011 & 0.87 & 16 & 0.90 & 3.9 & $\mathrm{BD}$ & 0.013 & 0.0018 \\
\hline J2-613-IGT4 & Beebe Vent 5 (2012) & 1.29 & 0.069 & 4.5 & 68 & 5.1 & 10 & $\mathrm{BD}$ & 0.057 & 0.0094 \\
\hline J2-618-IGT2 & Beebe Woods (2012) & 2.95 & 0.020 & 4.1 & 47 & 0.05 & $\mathrm{BD}$ & $\mathrm{BD}$ & 0.0022 & $\mathrm{BD}$ \\
\hline J2-618-IGT8 & Beebe Woods (2012) & 2.97 & 0.12 & 3.1 & 95 & 3.7 & 5.2 & $\mathrm{BD}$ & 0.11 & 0.014 \\
\hline J2-619-IGT6 & Hot Chimlet \#1 (2012) & 35.4 & 0.14 & 1.1 & 14 & 0.10 & 0.88 & $\mathrm{BD}$ & $\mathrm{BD}$ & $\mathrm{BD}$ \\
\hline J2-619-IGT3 & Hot Chimlet \#1 (2012) & 33.4 & 0.46 & 2.0 & 46 & 0.047 & 0.38 & $\mathrm{BD}$ & $\mathrm{BD}$ & $\mathrm{BD}$ \\
\hline J2-620-IGT4 & Hot Chimlet \#2 (2012) & 45.4 & 0.019 & 0.35 & 7.4 & 0.13 & 0.55 & $\mathrm{BD}$ & 0.0025 & $\mathrm{BD}$ \\
\hline J2-620-IGT8 & Hot Chimlet \#2 (2012) & 47.8 & $\mathrm{BD}$ & 0.16 & 3.7 & 0.048 & $\mathrm{BD}$ & $\mathrm{BD}$ & $\mathrm{BD}$ & $\mathrm{BD}$ \\
\hline J2-620-IGT1 & Shrimp Gulley \#1 (2012) & 42.4 & 0.034 & 1.0 & 36 & 0.45 & 0.58 & $\mathrm{BD}$ & 0.0063 & $\mathrm{BD}$ \\
\hline J2-620-IGT2 & Shrimp Gulley \#1 (2012) & 44.8 & $\mathrm{BD}$ & 0.70 & 2.6 & 0.10 & $\mathrm{BD}$ & $\mathrm{BD}$ & 0.0023 & $\mathrm{BD}$ \\
\hline J2-618-IGT1 & Shrimp Gulley \#2 (2012) & 47.4 & $\mathrm{BD}$ & 0.20 & 3.3 & 0.030 & 0.28 & $\mathrm{BD}$ & 0.0029 & $\mathrm{BD}$ \\
\hline J2-618-IGT3 & Shrimp Gulley \#2 (2012) & 48.9 & $\mathrm{BD}$ & 0.56 & 0.5 & 0.17 & 0.72 & $\mathrm{BD}$ & $\mathrm{BD}$ & $\mathrm{BD}$ \\
\hline
\end{tabular}


Table A3. Measured metal concentrations in the 'dregs' fraction of Piccard fluids.

\begin{tabular}{|c|c|c|c|c|c|c|c|c|c|c|}
\hline Vent (Year) & Sample & $\begin{array}{c}\mathrm{Mg} \\
\mathrm{mm}^{\dagger}\end{array}$ & $\begin{array}{c}\mathrm{Al} \\
\mu \mathrm{m}^{\dagger}\end{array}$ & $\begin{array}{l}\mathrm{Mn} \\
\mu \mathrm{m}\end{array}$ & $\begin{array}{l}\mathrm{Fe} \\
\mu \mathrm{m}\end{array}$ & $\begin{array}{l}\mathrm{Zn} \\
\mu \mathrm{m}\end{array}$ & $\begin{array}{l}\mathrm{Cu} \\
\mu \mathrm{m}\end{array}$ & $\begin{array}{l}\mathrm{Pb} \\
\mu \mathrm{m}\end{array}$ & $\begin{array}{l}\text { Co } \\
\mu \mathrm{m}\end{array}$ & $\begin{array}{l}\mathrm{Cd} \\
\mu \mathrm{m}\end{array}$ \\
\hline J2-613-IGT1 & Beebe Vent 1 (2012) & 0.96 & $\mathrm{BD}^{\ddagger}$ & 1.9 & 570 & 49 & 187 & - & 0.92 & 0.073 \\
\hline J2-613-IGT8 & Beebe Vent 1 (2012) & 1.34 & $\mathrm{BD}$ & 1.1 & 264 & 50 & 197 & - & 0.96 & 0.073 \\
\hline J2-619-IGT4 & Beebe Vent 3 (2012) & 1.26 & 1.7 & 2.3 & 464 & 55 & 347 & 2.6 & 0.84 & 0.10 \\
\hline J2-619-IGT8 & Beebe Vent 3 (2012) & 1.59 & $\mathrm{BD}$ & 1.2 & 424 & 0.42 & 50 & - & 1.3 & 0.075 \\
\hline J2-613-IGT3 & Beebe Vent 5 (2012) & 2.15 & $\mathrm{BD}$ & 0.82 & 343 & 78 & 126 & - & 0.91 & 0.081 \\
\hline J2-613-IGT4 & Beebe Vent 5 (2012) & 1.29 & $\mathrm{BD}$ & 1.4 & 224 & 45 & 152 & - & 1.0 & 0.079 \\
\hline J2-618-IGT2 & Beebe Woods (2012) & 2.95 & 1.367 & 2.4 & 7500 & 35 & 616 & 0.31 & 17 & 0.050 \\
\hline J2-618-IGT8 & Beebe Woods (2012) & 2.97 & 3.18 & 4.0 & 4759 & 26 & 635 & 0.33 & 11 & 0.035 \\
\hline J2-619-IGT6 & Hot Chimlet \#1 (2012) & 35.4 & 3.54 & 2.2 & 719 & 1.1 & 14 & 0.11 & 0.27 & 0.003 \\
\hline J2-619-IGT3 & Hot Chimlet \#1 (2012) & 33.4 & $-\ddagger$ & - & - & - & - & - & - & - \\
\hline J2-620-IGT4 & Hot Chimlet \#2 (2012) & 45.4 & 1.860 & 0.57 & 97.6 & 2.2 & 21 & 0.17 & 0.098 & 0.0046 \\
\hline J2-620-IGT8 & Hot Chimlet \#2 (2012) & 47.8 & 3.93 & 0.90 & 126 & 2.1 & 14 & 0.10 & 0.17 & 0.0030 \\
\hline J2-620-IGT1 & Shrimp Gulley \#1 (2012) & 42.4 & 7.883 & 12 & 1815 & 3.7 & 21 & 0.30 & 0.18 & 0.0075 \\
\hline J2-620-IGT2 & Shrimp Gulley \#1 (2012) & 44.8 & 1.925 & 2.0 & 1529 & 5.1 & 208 & 0.12 & 2.9 & 0.0097 \\
\hline J2-618-IGT1 & Shrimp Gulley \#2 (2012) & 47.4 & 0.92 & 0.46 & 62.3 & 1.1 & 7.5 & 0.077 & 0.11 & 0.0013 \\
\hline J2-618-IGT3 & Shrimp Gulley \#2 (2012) & 48.9 & 1.3 & 0.61 & 88.7 & 4.2 & 39 & 0.49 & $\mathrm{BD}$ & 0.011 \\
\hline
\end{tabular}




\section{REFERENCES}

Albarède, F., Michard, A., Minster, J.F., Michard, G. (1981) ${ }^{86} \mathrm{Sr} /{ }^{87} \mathrm{Sr}$ ratios in hydrothermal waters and deposits from the East Pacific Rise at $21^{\circ} \mathrm{N}$. Earth and Planetary Science Letters 55, 229-236.

American Public Health Association (1980) Standard methods for the examination of water and wastewater $15^{\text {th }}$ ed., Washington, DC, p. 448.

Beaulieu, S.E., BaKer, E.T., German, C.R., Maffei, A. (2013) An authoritative global database for active submarine hydrothermal vent fields. Geochemistry Geophysics Geosystems 14, 4892-4905.

Berndt, M.E., Seyfried, J., William E (2002) Calcium and sodium exchange during hydrothermal alteration of calcic plagioclase at $400^{\circ} \mathrm{C}$ and 400 bars. Geochimica et Cosmochimica Acta 57, 4445-4451.

Berndt, M.E., Seyfried, J., William E, Janecky, D.R. (1989) Plagioclase and epidote buffering of cation ratios in mid-ocean ridge hydrothermal fluids: Experimental results in and near the supercritical region. Geochimica et Cosmochimica Acta 53, 2283-2300.

Berndt, M.E., Seyfried, W.E., Beck, J.W. (1988) Hydrothermal Alteration Processes at Midocean Ridges: Experimental and Theoretical Constraints from Ca and Sr Exchange Reactions and Sr Isotopic Ratios. Journal of Geophysical Research 93, 4573-4583.

Bischoff, J.L. (1991) Densities of Liquids and Vapors in Boiling NaCl- $\mathrm{H}_{2} \mathrm{O}$ Solutions - a Pvtx Summary From $300^{\circ} \mathrm{C}$ to $500^{\circ} \mathrm{C}$. American Journal of Science 291, 309-338.

BisCHOFF, J.L., DiCKSON, F. (1975) Seawater-basalt interaction at $200^{\circ} \mathrm{C}$ and 500 bars: implications for origin of sea-floor heavy-metal deposits and regulation of seawater chemistry. Earth and Planetary Science Letters 25, 385-397.

BisCHOFF, J.L., RosenBAUER, R. (1988) Liquid-vapor relations in the critical region of the system $\mathrm{NaCl}-\mathrm{H} 2 \mathrm{O}$ from 380 to $415^{\circ} \mathrm{C}$ : A refined determination of the critical point and two-phase boundary of seawater. Geochimica et Cosmochimica Acta 52, 2121-2126.

Bischoff, J.L., RosenBAUER, R.J. (1985) An empirical equation of state for hydrothermal seawater (3.2 percent $\mathrm{NaCl}$ ). American Journal of Science 285, 725-763.

Bown, J.W., WhiTE, R.S. (1994) Variation with spreading rate of oceanic crustal thickness and geochemistry. Earth and Planetary Science Letters 121, 435-449. 
Charlou, J.L., Donval, J.P., Fouquet, Y., Jean-Baptiste, P., Holm, N. (2002) Geochemistry of high $\mathrm{H}_{2}$ and $\mathrm{CH}_{4}$ vent fluids issuing from ultramafic rocks at the Rainbow hydrothermal field (36 $14^{\prime}$ N, MAR). Chemical Geology 191, 345-359.

Charlou, J.L., Donval, J.P., Konn, C., Ondreacuteas, H., Fouquet, Y., Jean-Baptiste, P., FOURR, E., 2010. High production and fluxes of $\mathrm{H}_{2}$ and $\mathrm{CH}_{4}$ and evidence of abiotic hydrocarbon synthesis by serpentinization in ultramafic-hosted hydrothermal systems on the Mid-Atlantic Ridge, Diversity of Hydrothermal Systems on Slow Spreading Ocean Ridges. AGU, Washington, DC, pp. 265-296.

COHEN, R.S., O'NiOns, R.K. (1982) The lead, neodymium and strontium isotopic structure of ocean ridge basalts. Journal of Petrology 23, 299-324.

Connelly, D.P., Copley, J.T., Murton, B.J., Stansfield, K., Tyler, P.A., German, C.R., Van Dover, C.L., Amon, D., Furlong, M., Grindlay, N., Hayman, N., Hnerbach, V.H.u., Judge, M., Le Bas, T., McPhail, S., Meier, A., Nakamura, K.-I., Nye, V., Pebody, M., Pedersen, R.B., Plouviez, S., Sands, C., Searle, R.C., Stevenson, P., TAws, S., WiLCOX, S. (2012) Hydrothermal vent fields and chemosynthetic biota on the world's deepest seafloor spreading centre. Nature Communications 2, 1-9.

Craig, H., Lupton, J.E. (1976) Primordial neon, helium, and hydrogen in oceanic basalts. Earth and Planetary Science Letters 31, 369-385.

CRuse, A., SeEwALD, J. (2006) Geochemistry of low-molecular weight hydrocarbons in hydrothermal fluids from Middle Valley, northern Juan de Fuca Ridge. Geochimica et Cosmochimica Acta 70, 2073-2092.

Des Marais, D.J., Stallard, M.L., Nehring, N.L., Truesdell, A.H. (1988) Carbon isotope geochemistry of hydrocarbons in the Cerro Prieto geothermal field, Baja California Norte, Mexico. Chemical Geology 71, 159-167.

Douville, E., Charlou, J., Oelkers, E., Bienvenu, P., Colon, C., Donval, J., Fouquet, Y., Prieur, D., APPriou, P. (2002) The rainbow vent fluids ( $\left.36^{\circ} 14^{\prime} \mathrm{N}, \mathrm{MAR}\right)$ : the influence of ultramafic rocks and phase separation on trace metal content in Mid-Atlantic Ridge hydrothermal fluids. Chemical Geology 184, 37-48.

Druffel, E.R.M., Williams, P.M., BAuer, J.E., ErTel, J.R. (1992) Cycling of dissolved and Particulate Organic Matter in the Open Ocean. Journal of Geophysical Research: Oceans 97(C1), 15,639-15,659. 
Elthon, D., Ross, D.K., MeEn, J.K. (1995) Compositional variations of basaltic glasses from the Mid-Cayman Rise spreading center. Journal of Geophysical Research: Solid Earth (1978-2012) 100, 12497-12512.

Ewing, J., Antoine, J., EwIng, M. (1960) Geophysical measurements in the western Caribbean Sea and in the Gulf of Mexico. Journal of Geophysical Research: Solid Earth (19782012) $65,4087-4126$.

FOURNIER, R.O. (1983) A method of calculating quartz solubilities in aqueous sodium chloride solutions. Geochimica et Cosmochimica Acta 47, 579-586.

Galimov, E., Posyagin, V., Prokhorov, V. (1972) Carbon isotope fractionation as a function of temperature in the $\mathrm{CH}_{4}-\mathrm{C}_{2} \mathrm{H}_{6}-\mathrm{C}_{3} \mathrm{H}_{8}-\mathrm{C}_{4} \mathrm{H}_{10}$ system. Geokhimiya $\mathbf{8}, 977-987$.

Gallant, R.M., VON DAMM, K.L. (2006) Geochemical controls on hydrothermal fluids from the Kairei and Edmond Vent Fields, $23^{\circ}-25^{\circ} \mathrm{S}$, Central Indian Ridge. Geochemistry Geophysics Geosystems 7, Q06018.

GaO, X., Thiemens, M.H. (1991) Systematic study of sulfur isotopic composition in iron meteorites and the occurrence of excess 33S and 36S. Geochimica et Cosmochimica Acta 55, 2671-2679.

German, C.R., Bowen, A., Coleman, M., Honig, D., Huber, J., Jakuba, M., Kinsey, J., Kurz, M., Leroy, S., McDermott, J.M., Mercier de LéPinay, B., NAKamura, K., Seewald, J.S., Smith, J.L., Sylva, S.P., VAn Dover, C.L., Whitcomb, L.L., Yoerger, D.R. (2010) Diverse styles of submarine venting on the ultraslow spreading Mid-Cayman Rise. Proceedings of the National Academy of Sciences 107, 14020.

German, C.R., Seyfried JR, W.E. (2014) Hydrothermal Processes, in: Holland, H.D., Turekian, K.K. (Eds.), Treatise on Geochemistry (Second Edition). Elsevier, Oxford, pp. 191-233.

Hansell, D.A. CARlson, C.A. (1998) Deep-ocean gradients in the concentration of dissolved organic carbon. Nature 395, 263-266.

Hayman, N.W., Grindlay, N.R., Perfit, M.R., Mann, P., Leroy, S., De LéPinay, B.M. (2011) Oceanic core complex development at the ultraslow spreading Mid-Cayman Spreading Center. Geochemistry Geophysics Geosystems 12.

Helgeson, H., JM, D., HW, N., DK, B. (1978) Summary and critique of the thermodynamic properties of rock-forming minerals. American Journal of Science 278A, 1-229. 
Horita, J. (2001) Carbon isotope exchange in the system $\mathrm{CO}_{2}-\mathrm{CH}_{4}$ at elevated temperatures. Geochimica et Cosmochimica Acta 65, 1907-1919.

James, R.H., Elderfield, H., PAlmer, M.R. (1995) The chemistry of hydrothermal fluids from the Broken Spur site, 29 N Mid-Atlantic Ridge. Geochimica et Cosmochimica Acta 59, 651-659.

Johnson, J., OelKers, E., Helgesen, H. (1992) SUPCRT92: a software package for calculating the standard molal thermodynamic properties of minerals, gases, aqueous species, and reactions from 1 to 5000 bar and 0 to $1000^{\circ} \mathrm{C}$. Computational Geoscience 18, 899-947.

Joyce, T.M., Hernandez Guerra, A., Smethie, W.M. (2001) Zonal circulation in the NW Atlantic and Caribbean from a meridional World Ocean Circulation Experiment hydrographic section at $66^{\circ} \mathrm{W}$. Journal of Geophysical Research: Solid Earth (19782012) 106, 22095-22113.

KInSEY, J.C., GERMAN, C.R. (2013) Sustained volcanically-hosted venting at ultraslow ridges: Piccard Hydrothermal Field, Mid-Cayman Rise. Earth and Planetary Science Letters 380, $162-168$.

KLEIN, E.M., LANGMUIR, C.H. (1987) Global correlations of ocean ridge basalt chemistry with axial depth and crustal thickness. Journal of Geophysical Research: Solid Earth (19782012) 92, 8089-8115.

Koschinsky, A., Garbe-Schönberg, D., SAnder, S., Schmidt, K., Gennerich, H.-H., STRAUSS, H. (2008) Hydrothermal venting at pressure-temperature conditions above the critical point of seawater, $5^{\circ} \mathrm{S}$ on the Mid-Atlantic Ridge. Geology 36, 615.

Lorant, F., Prinzhofer, A., Behar, F., Huc, A.-Y. (1998) Carbon isotopic and molecular constraints on the formation and the expulsion of thermogenic hydrocarbon gases. Chemical Geology 147, 249-264.

LOTT, D.E. (2001) Improvements in noble gas separation methodology: A nude cryogenic trap. Geochemistry Geophysics Geosystems 2.

LuPTON, J.E., CRAIG, H. (1975) Excess ${ }^{3} \mathrm{He}$ in oceanic basalts: Evidence for terrestrial primordial helium. Earth and Planetary Science Letters 26, 133-139.

MCCOLlOM, T.M., BACH, W. (2009) Thermodynamic constraints on hydrogen generation during serpentinization of ultramafic rocks. Geochimica et Cosmochimica Acta 73, 856-875. 
Mотть, M.J. (1983) Metabasalts, axial hot springs, and the structure of hydrothermal systems at mid-ocean ridges. Geological Society of America Bulletin 94, 161.

MotTl, M.J., Holland, H.D. (1978) Chemical exchange during hydrothermal alteration of basalt by seawater - I. Experimental results for major and minor components of seawater. Geochimica et Cosmochimica Acta 42, 1103-1115.

Olsson, I. (1970) The use of oxalic acid as a standard, in: Olsson, I. (Ed.), Radiocarbon Variations and Absolute Chronology, Nobel Symposium, 12th Proc. John Wiley \& Sons, New York, p. 17.

OREMLAND, R.S., Des MARAIS, D.J. (1983) Distribution, abundance and carbon isotopic composition of gaseous hydrocarbons in Big Soda Lake, Nevada: an alkaline, meromictic lake. Geochimica et Cosmochimica Acta 47, 2107-2114.

Pester, N.J., Rough, M., Ding, K., Seyfried, J., William E (2011) A new Fe/Mn geothermometer for hydrothermal systems: Implications for high-salinity fluids at $13^{\circ} \mathrm{N}$ on the East Pacific Rise. Geochimica et Cosmochimica Acta 75, 7881-7892.

PIneAU, F., JaVOY, M. (1983) Carbon isotopes and concentrations in mid-oceanic ridge basalts. Earth and Planetary Science Letters 62, 239-257.

Proskurowski, G., Lilley, M., Seewald, J., Fruh-Green, G., Olson, E., Lupton, J., Sylva, S., Kelley, D. (2008) Abiogenic hydrocarbon production at Lost City hydrothermal field. Science 319, 604.

Ravizza, G., Blusztajn, J., Von Damm, K., Bray, A., Bach, W., Hart, S. (2001) Sr isotope variations in vent fluids from $9^{\circ} 46^{\prime}-9^{\circ} 54^{\prime} \mathrm{N}$ East Pacific Rise: evidence of a non-zero-Mg fluid component. Geochimica et Cosmochimica Acta 65, 729-739.

ReEves, E.P., McDermott, J.M., Seewald, J.S. (2014) Methanethiol production in mid-ocean ridge hydrothermal fluids. Proceedings of the National Academy of Sciences 111(15), 5474-5479.

Reeves, E.P., Seewald, J.S., Saccocia, P., Bach, W., Craddock, P.R., Shanks III, W.C., Sylva, S.P., Walsh, E., Pichler, T., Rosner, M. (2011) Geochemistry of hydrothermal fluids from the PACMANUS, Northeast Pual and Vienna Woods hydrothermal fields, Manus Basin, Papua New Guinea. Geochimica et Cosmochimica Acta 75, 1088-1123. 
Reveillaud, J., Reddington, E., McDermott, J.S., Meyer, J., Sylva, S.P., Seewald, J.S., GERMAN, C.R., HuBER, J. (in prep.) Subseafloor microbial communities in hydrogen-rich vent fluids from hydrothermal systems along the Mid-Cayman Rise.

Rooney, M.A., Claypool, G.E., Moses Chung, H. (1995) Modeling thermogenic gas generation using carbon isotope ratios of natural gas hydrocarbons. Chemical Geology 126, 219-232.

Rosencrantz, E., Ross, M., Sclater, J. (1988) Age and Spreading History of the Cayman Trough as Determined From Depth, Heat-Flow, and Magnetic-Anomalies. Journal of Geophysical Research-Solid Earth and Planets 93, 2141-2157.

Schoell, M. (1980) The hydrogen and carbon isotopic composition of methane from natural gases of various origins. Geochimica et Cosmochimica Acta 44, 649-661.

Schoell, M. (1988) Multiple origins of methane in the Earth. Chemical Geology 71, 1-10.

SeEwald, J.S., CRUSE, A., SACCOCIA, P. (2003) Aqueous volatiles in hydrothermal fluids from the Main Endeavour Field, northern Juan de Fuca Ridge: temporal variability following earthquake activity. Earth and Planetary Science Letters 216, 575-590.

SEeWALD, J.S., SEYFRIED JR, W.E. (1990) The effect of temperature on metal mobility in subseafloor hydrothermal systems: constraints from basalt alteration experiments. Earth and Planetary Science Letters 101, 388-403.

Seewald, J.S., Doherty, K.W., Hammar, T.R., Liberatore, S.P. (2002) A new gas-tight isobaric sampler for hydrothermal fluids. Deep Sea Research Part I: Oceanographic Research Papers 49, 189-196.

SEYFRIED JR, W.E., BISCHOFF, J. (1981) Experimental seawater-basalt interaction at 300 C, 500 bars, chemical exchange, secondary mineral formation and implications for the transport of heavy metals. Geochimica et Cosmochimica Acta 45, 135-147.

SEYFried JR, W.E., JANECKY, D.R., MotTL, M.J. (1984) Alteration of the oceanic crust: implications for geochemical cycles of lithium and boron. Geochimica et Cosmochimica Acta 48, 557-569.

SEYFRIED JR, W.E., JANECKY, D.R. (1985) Heavy metal and sulfur transport during subcritical and supercritical hydrothermal alteration of basalt: Influence of fluid pressure and basalt composition and crystallinity. Geochimica et Cosmochimica Acta 49, 2545-2560. 
SEYFRIED JR, W.E. (1987) Experimental and theoretical constraints on hydrothermal alteration processes at mid-ocean ridges. Annual Review of Earth and Planetary.

SEyfried JR, W.E., Ding, K. (1995) Phase Equilibria in Subseafloor Hydrothermal Systems: a Review of the Role of Redox, Temperature, $\mathrm{pH}$ and Dissolved $\mathrm{Cl}$ on the Chemistry of Hot Spring Fluids at Mid-Ocean Ridges, Seafloor Hydrothermal Systems: Physical, Chemical, Biological, and Geological Interactions. American Geophysical Union, pp. $248-272$.

Seyfried JR, W.E., Seewald, J.S., Berndt, M.E., Ding, K., Foustoukos, D.I. (2003)

Chemistry of hydrothermal vent fluids from the Main Endeavour Field, northern Juan de Fuca Ridge: Geochemical controls in the aftermath of June 1999 seismic events. Journal of Geophysical Research: Solid Earth 108, 2429.

SHANKS III, W.C. (2001) Stable isotopes in seafloor hydrothermal systems: vent fluids, hydrothermal deposits, hydrothermal alteration, and microbial processes. Reviews in Mineralogy and Geochemistry 43, 469.

SHOCK, E.L., C, H.H., A, S.D. (1989) Calculation of the thermodynamic and transport properties of aqueous species at high pressures and temperatures: Standard partial molal properties of inorganic neutral species. Geochimica et Cosmochimica Acta 53, 2157-2183.

SHOck, E.L., C, S.D., M, W., A, S.D. (1997) Inorganic species in geologic fluids: Correlations among standard molal thermodynamic properties of aqueous ions and hydroxide complexes. Geochimica et Cosmochimica Acta 61, 907-950.

ShOcK, E.L., Helgeson, N. (1988) Calculation of the thermodynamic and transport properties of aqueous species at high pressures and temperatures: Correlation algorithms for ionic species and equation of state predictions to $5 \mathrm{~kb}$ and $1000^{\circ} \mathrm{C}$. Geochimica et Cosmochimica Acta 52, 2009-2036.

Sourirajan, S., Kennedy, G.C. (2006) The system H2O-NaCl at elevated temperatures and pressures. American Journal of Science 260, 115-141.

Takai, K., Gamo, T., Tsunogai, U., Nakayama, N., Hirayama, H., Nealson, K., Horikoshi, K. (2004) Geochemical and microbiological evidence for a hydrogen-based, hyperthermophilic subsurface lithoautotrophic microbial ecosystem (HyperSLiME) beneath an active deep-sea hydrothermal field. Extremophiles $\mathbf{8}$. 
Takai, K., Nakamura, K., Toki, T., Tsunogai, U., Miyazaki, M., Miyazaki, J., Hirayama, H., Nakagawa, S., Nunoura, T., Horikoshi, K. (2008) Cell proliferation at $122^{\circ} \mathrm{C}$ and isotopically heavy $\mathrm{CH}_{4}$ production by a hyperthermophilic methanogen under highpressure cultivation. Proceedings of the National Academy of Sciences of the United States of America 105, 10949-10954.

TEn Brink, U., Coleman, D., Dillon, W. (2002) The nature of the crust under Cayman Trough from gravity. Marine and Petroleum Geology 19, 971-987.

VON DAMM, K.L. (1990) Seafloor hydrothermal activity: black smoker chemistry and chimneys. Annual Review of Earth and Planetary Sciences 18, 173.

VON DAMM, K.L. (1995) Controls on the chemistry and temporal variability of seafloorhydrothermal fluids. AGU, Washington DC.

VON DAMM, K.L. (2000) Chemistry of hydrothermal vent fluids from 9-10 N, East Pacific Rise: “Time zero," the immediate posteruptive period. J. Geophys. Res 105, 11203-11222.

Von DAmM, K.L., Bischoff, J., RosenbAuer, R. (1991) Quartz solubility in hydrothermal seawater: an experimental study and equation describing quartz solubility for up to $0.5 \mathrm{M}$ $\mathrm{NaCl}$ solutions. American Journal of Science 291, 977-1007.

Von Damm, K.L., Edmond, J.M., Grant, B., Walden, B., Weiss, R.F. (1985) Chemistry of submarine hydrothermal solutions at 21 N, East Pacific Rise. Geochimica et Cosmochimica Acta 49, 2197-2220.

Voss, B.M., Peucker-Ehrenbrink, B., Eglinton, T.I., Fiske, G., Wang, Z.A., Hoering, K.A., Montluçon, D.B., LeCroy, C., Pal, S., Marsh, S., Gillies, S.L., JanmaAt, A., Bennett, M., Downey, B., Fanslau, J., Fraser, H., Macklam-Harron, G., Martinec, M., WieBe, B. (2014) Tracing river chemistry in space and time: Dissolved inorganic constituents of the Fraser River, Canada. Geochimica et Cosmochimica Acta 124, 283-308.

Welhan, J.A. (1988) Origins of methane in hydrothermal systems. Chemical Geology 71, 183198.

White, R., Minshull, T., Bickle, M., Robinson, C. (2001) Melt generation at very slowspreading oceanic ridges: Constraints from geochemical and geophysical data. Journal of Petrology 42, 1171-1196. 
White, R.S., McKenzie, D., O’Nions, R.K. (1992) Oceanic crustal thickness from seismic measurements and rare earth element inversions. Journal of Geophysical Research: Solid Earth (1978-2012) 97, 19683-19715.

Wilson, S.C., Murton, B.J., TAYlor, R.N. (2013) Mantle composition controls the development of an Oceanic Core Complex. Geochemistry Geophysics Geosystems, 1-18.

Wolery, T.J., 1992. EQ3NR, A Computer Program for Geochemical Aqueous SpeciationSolubility Calculations: Theoretical Manual, User's Guide, and Related Documentation (Version 7.0). Lawrence Livermore National Lab.

Wolery, T.J., DAveler, S.A., 1992. EQ6, A Computer Program for Reaction Path Modeling of Aqueous Geochemical Systems: Theoretical Manual, User's Guide, and Related Documents. Lawrence Livermore National Lab. 


\title{
CHAPTER 5
}

\section{Identification of sulfur sources and isotopic equilibria in submarine hot-springs using multiple sulfur isotopes}

(This chapter was submitted to Geochimica et Cosmochimica Acta, April 15 ${ }^{\text {th }}, 2014$, and is currently under revision as a co-authored paper with Shuhei Ono, Margaret K. Tivey, Jeffrey S. Seewald, Wayne C. Shanks III and Andrew R. Solow.)

\begin{abstract}
Multiple sulfur isotopes were measured on metal sulfide deposits, elemental sulfur, and fluid hydrogen sulfide to constrain sulfur sources and the isotopic systematics of precipitation in seafloor hydrothermal vents. Areas studied include the eastern Manus Basin and Lau Basin back-arc spreading centers and the unsedimented basalt-hosted Southern East Pacific Rise (SEPR) and sediment-hosted Guaymas Basin mid-ocean ridge spreading centers. Chalcopyrite and hydrogen sulfide $\left(\mathrm{H}_{2} \mathrm{~S}\right) \delta^{34} \mathrm{~S}$ values range from $-5.5 \%$ to $+5.6 \%$ in Manus Basin samples, $+2.4 \%$ to $+6.1 \%$ in Lau Basin samples, $+3.7 \%$ to $+5.7 \%$ in SEPR samples, and cubic cubanite
\end{abstract}


and $\mathrm{H}_{2} \mathrm{~S}$ range from $-1.4 \%$ to $+4.7 \%$ in Guaymas Basin samples. In contrast with previous

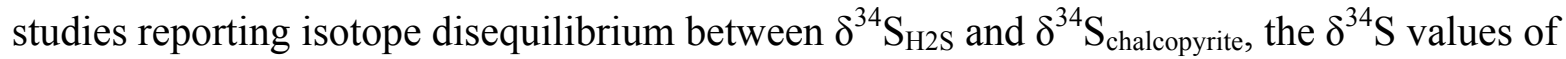
chalcopyrite sampled from the inner $1-2 \mathrm{~mm}$ of a chimney wall are within $\pm 1 \%$ of $\mathrm{H}_{2} \mathrm{~S}$ from the paired vent fluid, suggesting equilibrium fluid-mineral sulfur isotope exchange at $300-400^{\circ} \mathrm{C}$. Limited isotope fractionation between hydrothermal fluid $\mathrm{H}_{2} \mathrm{~S}$ and precipitating chalcopyrite implies that sulfur isotopes in the chalcopyrite lining across a chimney wall may accurately record past hydrothermal activity.

Sulfur isotope systematics in fluid-mineral pairs from the PACMANUS and SuSu Knolls hydrothermal systems in the eastern Manus Basin indicate a significant contribution of sulfur derived from disproportionation of magmatic sulfur dioxide $\left(\mathrm{SO}_{2}\right)$ as evidenced by negative $\delta^{34} \mathrm{~S}$ values and $\Delta^{33} \mathrm{~S}$ values consistent with a disproportionation origin, rather than a biogenic sulfide source. At the sedimented Guaymas hydrothermal system, negative $\delta^{34} \mathrm{~S}$ values were also measured in some vent fluid $\mathrm{H}_{2} \mathrm{~S}$ and a fluid-mineral pair. Further, $\delta^{34} \mathrm{~S}$ values of hydrogen sulfide correlate with the $\delta^{13} \mathrm{C}$ values of ethane and ratios of methane to longer hydrocarbons, suggesting that fluid interaction with fresher, less-altered sediment supplies ${ }^{34}$ S-enriched sulfur to vent fluid hydrogen sulfide by thermochemical sulfate reduction. 


\section{INTRODUCTION}

In deep-sea hydrothermal systems, circulating seawater extracts heat from young oceanic crust while undergoing a variety of water-rock reactions and entraining magmatic gases. The resultant hot, buoyant and chemically altered fluids are discharged as metal-rich vent fluids on the seafloor, precipitating metal-rich mineral deposits during cooling and mixing with ambient seawater. Collectively, these processes substantially influence global heat budgets, chemical fluxes, and the isotopic composition of seawater (EDMOND et al., 1979; ELDERFIELD et al., 1993; ELDERFIELD AND SCHULTZ, 1996; FARQUHAR et al., 2010; JAFFRÉs et al., 2007; STAUDIGEL and HART, 1983; VON DAMM, 1995; VON DAMM et al., 1985).

As the subsurface of active hydrothermal systems is rarely accessible to direct observation, inferences from vent fluid and mineral deposit chemistry are an important means of characterizing processes occurring in the shallow subsurface and at depth. In particular, the sulfur isotope signatures of hydrothermal vent fluids and associated mineral deposits can be used to identify sulfur sources and examine metal sulfide mineral precipitation processes in active deep sea hydrothermal systems. As metal- and sulfide-rich, high-temperature $\left(350\right.$ to $\left.400^{\circ} \mathrm{C}\right)$ 'black smoker' vent fluids ascend toward the seafloor and cool, metal sulfides may precipitate at and below the seafloor. Because metal sulfide deposits record the isotopic composition of hydrothermal fluids responsible for their formation, they can be used to assess temporal evolution within a hydrothermal system, provided that isotope systematics during mineral precipitation are well understood.

Sulfur sources in hydrothermal systems may include sulfide present in crustal host rocks, bacterial or thermochemical reduction of seawater-derived sulfate $\left(\mathrm{SO}_{4}\right)$ to hydrogen sulfide $\left(\mathrm{H}_{2} \mathrm{~S}\right)$, magmatic volatiles $\left(\mathrm{H}_{2} \mathrm{~S}\right.$ or $\left.\mathrm{SO}_{2}\right)$, and, at sedimented spreading centers, sedimentary pyrite 
and organic-derived S. Studies over the last thirty years have utilized the two major stable sulfur isotopes $\left({ }^{34} \mathrm{~S}\right.$ and $\left.{ }^{32} \mathrm{~S}\right)$ to identify sources of sulfur and fluid-mineral interaction during hydrothermal circulation. Previous studies have recognized that vent fluid $\mathrm{H}_{2} \mathrm{~S}$ and co-existing metal sulfides are often not in isotopic equilibrium at measured vent temperatures (KERRIDGE et al., 1983; Bluth and Ohmoto, 1988; WoodrufF and Shanks, 1988; Shanks, 2001; Ono et al., 2007; RouXEL et al., 2008). Some authors have suggested that kinetic isotope effects occur during rapid precipitation, while others have suggested that temporal variations in vent fluid $\delta^{34} \mathrm{~S}$ produce micro-layers of precipitated sulfide that are difficult to correlate to concurrently sampled fluids, however the cause of disequilibrium in these systems remains enigmatic.

Recent advances in multiple stable isotope analytical techniques now enable the precise determination of the four stable isotopes of $\mathrm{S}:{ }^{32} \mathrm{~S},{ }^{33} \mathrm{~S},{ }^{34} \mathrm{~S}$, and ${ }^{36} \mathrm{~S}$, with natural terrestrial abundances of approximately $95.02 \%, 0.75 \%, 4.21 \%$, and $0.02 \%$, respectively (MACNAMARA and THODE, 1950). Multiple sulfur isotope studies have shown that many modern biologicallymediated processes, particularly those involving reaction intermediates or branched reactions (e.g. microbial metabolism), are characterized by mass-dependent fractionation that is discernibly different than equilibrium predictions (FARQUHAR et al., 2003; JOHNSTON et al., 2005; SIM et al., 2011). Temperature-dependent equilibrium isotopic exchange between Scontaining species (e.g. $\mathrm{SO}_{4}-\mathrm{H}_{2} \mathrm{~S}$ ) also generates differences in multiple sulfur isotope signatures, making it possible to distinguish between mixing and isotope exchange processes. For example, ONO et al. (2007) used multiple sulfur isotopes to demonstrate that fluid $\mathrm{H}_{2} \mathrm{~S}$ and metal sulfide deposits at the $9^{\circ} \mathrm{N}$ East Pacific Rise hydrothermal field may be impacted by various degrees of isotope exchange with subsurface seawater-derived $\mathrm{SO}_{4}$ or anhydrite. 
Since high-temperature hydrothermal processes facilitate equilibrium isotope fractionations, high-precision measurements of ${ }^{33} \mathrm{~S}$ may provide additional information identifying biogenic sulfide sources when $\delta^{34} \mathrm{~S}$ values are inconclusive (ONO et al., 2007). In the present study multiple sulfur isotopes of inner-wall chalcopyrite, fluid $\mathrm{H}_{2} \mathrm{~S}$, and elemental sulfur $\left(\mathrm{S}^{0}\right)$ were determined to examine the systematics of fractionation during mineral precipitation and identify sulfur sources in a broad spectrum of deep sea hydrothermal systems.

\section{SAMPLE DESCRIPTION}

The collection of vent fluids and mineral deposits through which they flow (fluid-mineral pairs) allows evaluation of the degree to which fluid temperature and chemistry influences the mineralogy and isotope composition of a deposit. This study includes well-characterized fluidmineral pairs from a variety of deep sea hydrothermal systems, including two back-arc spreading centers at Lau Basin and Manus Basin, the mid-ocean ridge spreading center at the Southern East Pacific Rise (SEPR), and Guaymas Basin, a sediment-covered spreading center in the Gulf of California (Table 1).

In the three bare-rock systems chalcopyrite $\left(\mathrm{CuFeS}_{2}\right)$ was collected from the inner 1-2 $\mathrm{mm}$ of active sulfide chimney walls from which high temperature black-smoker fluids were sampled. Chimney samples were characterized using thin section petrography, and those with chalcopyrite-dominant linings (and two with inter-grown chalcopyrite and pyrite, Table 2) were selected for study. Approximately $10 \mathrm{mg}$ of chalcopyrite (or chalcopyrite with trace pyrite) from each sample was handpicked using a binocular microscope to minimize incorporation of trace anhydrite and pyrite. Because chalcopyrite chimney linings do not form at the sediment-covered Guaymas Basin, cubic cubanite $\left(\mathrm{CuFe}_{2} \mathrm{~S}_{3}\right)$ precipitated onto a titanium-sheathed thermocouple 
array during a 72 day coupled mineral and microbial growth experiment (PAGÉ et al., 2008) was used for this study. This mineral coating along with a concurrently-sampled fluid are included as a single fluid-cubic cubanite pair, as well as several fluid samples from Guaymas Basin that were collected in 2003 and 2008 without corresponding mineral pairs.

All Manus, Lau, and Guaymas Basin fluid samples were collected using titanium isobaric gas-tight (IGT) samplers (SEEWALD et al., 2002), while the SEPR fluids were collected using non-gas-tight titanium syringe-type 'major' samplers (VON DAMM et al., 1985). In most instances, fluids were collected immediately after sampling the associated chimney structure. During collection of all fluids, vent temperature was monitored in real-time using thermocouple probes mounted on the bottle snorkels. Maximum measured temperatures are reported for each vent (Table 1). Metal-rich black smokers were sampled at most locations. At North Su and the nearby DESMOS caldera in the Eastern Manus Basin, lower temperature, lower metal, and very low $\mathrm{pH}$ 'acid-sulfate' type fluids were also sampled directly from the dome flanks (SEEWALD et al., in review) (Table 1). The acid spring fluids contain $\mathrm{S}^{0}$ particles, and molten $\mathrm{S}^{0}$ deposits surround the vents. In addition to sampling aqueous $\mathrm{H}_{2} \mathrm{~S}$ and sulfide minerals in the black

smoker fluids, $\mathrm{S}^{0}$ precipitates were filtered from acid-spring type fluids collected on the flanks of North Su and the neighboring DESMOS caldera, and $\mathrm{S}^{0}$ deposits were also collected on the seafloor at each acid spring location.

\section{AnAlytical Methods}

\subsection{Sulfide minerals}

Picked chalcopyrite grains were placed in $\mathrm{HCl}$-cleaned Teflon ${ }^{\circledR}$ vials and cleaned in $1 \mathrm{~N}$ $\mathrm{HCl}$ for several hours to remove surface tarnish before grinding to a fine powder in ethanol. Following established methods, chalcopyrite was dissolved in $5 \mathrm{~mL}$ aqua regia to oxidize sulfur 
and evaporated to dryness at $150^{\circ} \mathrm{C}$ (RouXEL et al., 2008; SHANKS, 2001). The dry residue was re-dissolved in water, and a $0.4 \mathrm{M} \mathrm{BaCl}_{2}$ solution was added to precipitate $\mathrm{BaSO}_{4}$. After drying overnight at $80^{\circ} \mathrm{C}, \mathrm{BaSO}_{4}$ was reduced to $\mathrm{Ag}_{2} \mathrm{~S}$ via the Thode solution procedure (FORREST and NeWMAN, 1977; ThODE et al., 1961). $\mathrm{S}^{0}$ samples were reduced to $\mathrm{Ag}_{2} \mathrm{~S}$ using the chromium reduction method (CANFIELD et al., 1986), with increased $\mathrm{Cr}^{2+}$ solution volume and longer boiling time to increase yield. Yields for Thode solution and chromium reduction conversions were $>90 \%$. Precipitated $\mathrm{Ag}_{2} \mathrm{~S}$ was heated in an $\mathrm{AgNO}_{3}$ solution before rinsing with deionized water and drying at $80^{\circ} \mathrm{C}$.

\subsection{Hydrothermal Fluids}

Gas-tight fluid samples were acidified at sea with phosphoric acid and evolved $\Sigma \mathrm{H}_{2} \mathrm{~S}$ $\left(\mathrm{H}_{2} \mathrm{~S}+\mathrm{S}^{2-}\right.$, hereafter abbreviated $\left.\mathrm{H}_{2} \mathrm{~S}\right)$ was bubbled through a 5 wt. \% $\mathrm{AgNO}_{3}$ solution to precipitate $\mathrm{Ag}_{2} \mathrm{~S}$ for gravimetric determination of concentration and isotopic analysis. The SEPR fluids were collected in 'majors' samplers, and SEPR $\mathrm{H}_{2} \mathrm{~S}$ was converted to $\mathrm{Ag}_{2} \mathrm{~S}$ following the methods described by SHANKS (2001), which involve injection of $\mathrm{H}_{2} \mathrm{~S}$-bearing fluid samples into

evacuated glass vessels containing $\mathrm{Zn}^{2+}$ to precipitate $\mathrm{ZnS}$ that was later converted to $\mathrm{Ag}_{2} \mathrm{~S}$ in a shore-based laboratory.

Due to pre-filling of fluid sampler dead volume with bottom seawater, and occasional inadvertent entrainment of ambient seawater during sample collection, seawater always comprises some volume of a hydrothermal fluid sample. Based on laboratory studies that show $\mathrm{Mg} \approx 0 \mathrm{mmol} / \mathrm{kg}$ during high temperature fluid-rock and fluid-sediment interaction (e.g. SEYFRIED and BISCHOFF, 1981), $\mathrm{Cl}$ and $\mathrm{H}_{2} \mathrm{~S}$ 'endmember' fluid concentrations are calculated for each high temperature vent fluid using a least-squares regression of an individual chemical species versus $\mathrm{Mg}$ for all samples from one vent, assuming passage through the ambient bottom 
seawater composition and extrapolating to $0 \mathrm{mmol} / \mathrm{kg} \mathrm{Mg}$. For calculation of endmember $\mathrm{Cl}$ concentrations, all samples were included in the regression (major and gastight bottles, Table 1), while just gas-tight samples were used to determine $\mathrm{H}_{2} \mathrm{~S}$ concentrations. Fluid $\mathrm{pH}\left(25^{\circ} \mathrm{C}\right)$ is measured shipboard immediately following recovery using a $\mathrm{Ag} / \mathrm{AgCl}$ combination reference electrode. Endmembers are not calculated for $\mathrm{pH}\left(25^{\circ} \mathrm{C}\right)$ because $\mathrm{pH}$ does not behave conservatively during mixing with seawater. Minimum $\mathrm{pH}\left(25^{\circ} \mathrm{C}\right)$, which typically corresponds to a low-Mg $(<5 \mathrm{mmol} / \mathrm{kg})$ sample, is reported for each vent. The concept of an endmember composition, as applied for high temperature black smoker-type fluids, does not apply to the acid spring fluids venting on the flanks of North Su and at DESMOS. In contrast, the composition of these fluids is consistent with the subsurface mixing of low salinity volatile-rich $\left(\mathrm{H}_{2} \mathrm{O}, \mathrm{CO}_{2}, \mathrm{SO}_{2}\right.$, $\mathrm{HCl}$, and $\mathrm{HF}$ ) magmatic fluids with seawater prior to venting at the seafloor (SEEWALD et al., in review).

\subsection{Isotopic Measurements}

Multiple sulfur isotope values were determined via isotope ratio mass-spectrometry (Thermo-electron MAT 253) at MIT by a procedure similar to that described in ONO et al. (2006) (Table 2). Powdered $\mathrm{Ag}_{2} \mathrm{~S}(2 \mathrm{mg}$ ) was heated in an elemental fluorine atmosphere overnight to generate $\mathrm{SF}_{6}$, which was purified using gas chromatography and transferred into the mass spectrometer for simultaneous measurement of masses 127, 128, 129, and 131

(corresponding to ${ }^{32} \mathrm{SF}_{5}{ }^{+},{ }^{33} \mathrm{SF}_{5}{ }^{+},{ }^{34} \mathrm{SF}_{5}{ }^{+}$, and ${ }^{36} \mathrm{SF}_{5}{ }^{+}$). Isotope ratios are presented in the common $\delta$ notation in per mil (\%o): 


$$
\delta^{x} \mathrm{~S}=\left(\frac{{ }^{x} \mathrm{R}_{\text {sample }}}{{ }^{x} \mathrm{R}_{\mathrm{VCDT}}}-1\right) \times 1000(\% \text { o })
$$

where ${ }^{x} \mathrm{R}$ is the isotope ratio, ${ }^{x} \mathrm{~S} /{ }^{32} \mathrm{~S}(x=33,34$, or 36), of sample and Vienna Cañon Diablo Troilite (VCDT). The VCDT reference scale is defined by IAEA S-1 (artificially prepared $\operatorname{Ag}_{2} \mathrm{~S}$ ) with $\delta^{34} \mathrm{~S}_{\mathrm{VCDT}}$ equal to -0.3 (COPLEN and Krouse, 1998). Capital delta notation is defined as the deviation of a minor isotope ratio from a mass-dependent fractionation line (GAO and THIEMENS, 1991):

$$
\begin{aligned}
& \Delta^{33} S=\delta^{33} S-0.515 \times \delta^{34} S \\
& \Delta^{36} S=\delta^{36} S-1.90 \times \delta^{34} S
\end{aligned}
$$

Because most of the sources of analytical error are mass-dependent, the precision of $\Delta^{33} \mathrm{~S}$ measurements is higher than that of $\delta^{33} \mathrm{~S}$ and $\delta^{34} \mathrm{~S}$ measurements (i.e. errors in $\delta^{33} \mathrm{~S}$ and $\delta^{34} \mathrm{~S}$ are related). Replicate analysis of IAEA S-1 indicate $1 \sigma$ reproducibilities of $\pm 0.007 \%$ for $\Delta^{33} S$ and $\pm 0.095 \%$ for $\Delta^{36} \mathrm{~S}$ (ONO et al., 2012). Sufficient significant digits are reported in Table 2 to allow inter-conversion between linear and logarithmic capital delta definitions. The $\Delta^{36} \mathrm{~S}$ measurements do not provide additional information within the range of $\Delta^{33} \mathrm{~S}$ measured in this study and are not discussed here.

\section{RESULTS}

The values of $\delta^{34} \mathrm{~S}_{\mathrm{H}_{2} \mathrm{~S}}$ and $\delta^{34} \mathrm{~S}_{\text {chalcopyrite }}$ for all measured fluids and minerals (-5.5\%o to $+6.1 \%$ ) span the range of previously measured values at deep-sea hydrothermal vents (Fig. 1) 
(SHANKS, 2001). All measured fluids and minerals are characterized by $\Delta^{33} \mathrm{~S}$ values equal to zero within error (Fig. 1).

Among the five sites in this study, the back-arc PACMANUS vent field in the eastern Manus Basin shows the largest isotopic variability, with vent chimney $\delta^{34} \mathrm{~S}_{\text {chalcopyrite }}$ values ranging from $-0.8 \%$ o to $+5.6 \%$ and vent fluid $\delta^{34} \mathrm{~S}_{\mathrm{H}_{2} \mathrm{~S}}$ values ranging from $+0.5 \%$ to $+5.4 \%$ (Fig. 1a). At PACMANUS, Roger's Ruins vent fluid $\mathrm{H}_{2} \mathrm{~S}$ and chalcopyrite are the most ${ }^{34} \mathrm{~S}$-enriched, followed by the Roman Ruins and Satanic Mills vents (Fig. 1a), consistent with $\delta^{34} \mathrm{~S}_{\mathrm{H}_{2} \mathrm{~S}}$ values reported by REEVES et al. (2011).

At the SuSu Knolls vent field, also located in the eastern Manus Basin, vent chimney $\delta^{34} \mathrm{~S}_{\text {chalcopyrite }}$ values range from $-5.5 \%$ to $-4.1 \%$ and vent fluid values range from $-5.0 \%$ o to $4.5 \%$, while $\delta^{34} \mathrm{~S}_{\mathrm{S}^{0} \text { particle }}$ values for filtered $\mathrm{S}^{0}$ particles range from $-3.6 \%$ to $-1.4 \%$, similar to values of $-2.5 \%$ and $-3.7 \%$ or two adjacent seafloor $\mathrm{S}^{0}$ deposits (Fig. 1b). The $\mathrm{S}^{0}$ samples at DESMOS are generally more ${ }^{34} \mathrm{~S}$-depleted than SuSu Knolls, with $\delta^{34} \mathrm{~S}_{\mathrm{S}^{0} \text { particle }}$ values ranging from $-7.7 \%$ to $-4.8 \%$ that are slightly more ${ }^{34} \mathrm{~S}$-enriched than $\delta^{34} \mathrm{~S}_{\mathrm{S}^{0} \text { deposit }}$ values of $-7.6 \%$ and $8.2 \%$ for two nearby seafloor $\mathrm{S}^{0}$ deposits (Fig. 1b).

At Lau Basin, vent chimney $\delta^{34} \mathrm{~S}_{\text {chalcopyrite values range from }+3.1 \% \text { o to }+5.3 \% \text { and vent }}$ fluid $\delta^{34} \mathrm{~S}_{\mathrm{H}_{2} \mathrm{~S}}$ values range from $+2.4 \%$ to $+6.1 \%$ (Fig. 1c). The Mariner vent is the most ${ }^{34} \mathrm{~S}$ enriched, followed by ABE and Tui Malila. Vents at SEPR exhibit the smallest spread in sulfur isotope values in comparison with Manus, Lau, and Guaymas Basins, with vent chimney $\delta^{34} \mathrm{~S}_{\text {chalcopyrite values ranging from }+3.7 \% \text { to }}+4.7 \%$ and vent fluid $\delta^{34} \mathrm{~S}_{\mathrm{H}_{2} \mathrm{~S}}$ values ranging from $+3.7 \%$ to $+5.7 \%$ o (Fig. $1 \mathrm{~d})$. 
Vents at the sediment-covered Guaymas Basin hydrothermal system display nearly as broad a range in $\delta^{34} \mathrm{~S}$ values as at PACMANUS, with a single vent deposit $\delta^{34} \mathrm{~S}_{\text {cubic cubanite value }}$ of $-1.4 \%$ and vent fluid $\delta^{34} \mathrm{~S}_{\mathrm{H}_{2} \mathrm{~S}}$ values from $-0.6 \%$ to $+4.7 \%$ (Fig. 1e). The fluid-cubic cubanite pair from Busted Mushroom and fluid $\mathrm{H}_{2} \mathrm{~S}$ from Rebecca's Roost are more ${ }^{34} \mathrm{~S}$-depleted with $\delta^{34} \mathrm{~S}$ values between $-1.4 \%$ and $-0.4 \%$, while $\mathrm{H}_{2} \mathrm{~S}$ in Cathedral Hill and Theme Park vent fluids

are more ${ }^{34} \mathrm{~S}$-enriched, with $\delta^{34} \mathrm{~S}$ values between $+2.3 \%$ and $+4.7 \%$. These results fall within the $-4 \%$ o to $+4 \%$ o $\delta^{34} \mathrm{~S}$ range previously observed in pyrrhotite, sphalerite, and cubic cubanite deposits at Guaymas Basin (PETER and SHANKS, 1992).

\section{DisCUSSION}

\subsection{Fractionation during sulfide precipitation}

Previous sulfur isotope studies of ridge-crest hydrothermal systems have recognized that vent $\mathrm{H}_{2} \mathrm{~S}$ is typically enriched in ${ }^{34} \mathrm{~S}$ by +1.0 to $+1.5 \%$ o relative to co-existing inner chimney lining metal sulfides, and in some samples enrichments up to $+4 \%$ o have been observed (BLUTH and OHMOto, 1988; KerRidGe et al., 1983; Ono et al., 2007; RouXEL et al., 2008; SHANKS, 2001; WoODRUFF and SHANKS, 1988). These differences are substantially greater than the $<1 \%$ o equilibrium isotope fractionation predicted between chalcopyrite and fluid $\mathrm{H}_{2} \mathrm{~S}$ (KAJIWARA and KROUSE, 1971; Li and LIU, 2006), and are somewhat unexpected at the high-temperature, acidic conditions in black smoker vent fluids (Онмото and LASAGA, 1982). Several explanations have been invoked to account for the observed disequilibria, including kinetic fractionation during precipitation (KERRIDGE et al., 1983), or changes in the sulfur isotopic composition of vent fluid $\mathrm{H}_{2} \mathrm{~S}$ over time due to variations in the relative proportions of basalt-derived versus seawater $\mathrm{SO}_{4}$ 
reduction-derived $\mathrm{H}_{2} \mathrm{~S}$ (Bluth and OHmoto, 1988; WoodrufF and Shanks, 1988; Shanks et al., 1998).

The present study focuses on comparing isotope signatures of fluid $\mathrm{H}_{2} \mathrm{~S}$ to copper iron sulfide minerals at fine scale (1-2 $\mathrm{mm}$ into the lining), to directly address the question of fractionation systematics during precipitation. An experimental study indicates that chalcopyrite is ${ }^{34} \mathrm{~S}$-depleted by $\sim 0.1 \%$ with respect to the $\mathrm{H}_{2} \mathrm{~S}$ from which it precipitates and the equilibrium fractionation factor $\Delta^{34} \mathrm{~S}_{\mathrm{CuFeS}_{2}-\mathrm{H}_{2} \mathrm{~S}}$ is insensitive to temperature in the $200^{\circ} \mathrm{C}$ to $350^{\circ} \mathrm{C}$ range (KAJIWARA and KROUSE, 1971) (Fig. 2). A more recent study (Li and LiU, 2006) reports a calculated $\Delta^{34} \mathrm{~S}_{\mathrm{CuFeS}_{2}-\mathrm{H}_{2} \mathrm{~S}}$ of the same magnitude but with opposite sign, such that chalcopyrite is ${ }^{34} \mathrm{~S}$-enriched with respect to $\mathrm{H}_{2} \mathrm{~S}$ by $\sim 0.1 \%$.

Fluid-mineral pair chalcopyrite and $\mathrm{H}_{2} \mathrm{~S} \delta^{34} \mathrm{~S}$ values co-vary and are similar to abundances predicted for isotopic equilibrium (Fig. 2). To determine whether the sulfur isotopic compositions of coexisting fluids and minerals are consistent with isotopic equilibrium, we used a statistical model (see Appendix) to estimate the value of $A$, the unknown fractionation factor of primary interest, from the data in Fig. 2. The model explicitly accounts for uncertainties in the measurement of $\delta^{34} \mathrm{~S}_{\text {chalcopyrite }}$ and arising from analytical error and other errors associated with sample collection and processing. The basic statistical model is:

$$
Y_{j k l}=\mu_{1 k}+A T_{k}^{-2} I_{2}(j)+\varepsilon_{j k l}
$$

Here, $Y_{j k l}$ is the $\delta^{34} \mathrm{~S}$ measurement of sample type $j\left(j=1\right.$ for $\mathrm{H}_{2} \mathrm{~S}, j=2$ for chalcopyrite) at vent $k(k=1,2, \ldots, 15)$ for sample $l$. The subscript $l$ runs from 1 to the number of measurements of 
type $j$ at vent $k$. The $\mu_{j k}$ term is the unknown mean value of $\delta^{34} \mathrm{~S}_{\mathrm{H}_{2} \mathrm{~S}}$ at vent $k, A$ is the unknown fractionation factor of primary interest, $T_{k}$ is the maximum temperature measured at vent $k$, $I_{2}(j)$ is a binary indicator taking value 1 if $j=1$ and 0 otherwise, and $\varepsilon_{j k l}$ is a normal error with mean 0 comprising both analytical error of known variance and other uncertainty of unknown variance.

Regression of the data presented here yields an estimated value for $A$ of $-0.11 \times 10^{-6}$ $\pm 0.12 \times 10^{-6}$ at the 0.95 confidence limit. This value suggests that the sulfur isotopic compositions of fluid-pairs are consistent with equilibrium fractionation according to the experimental model of KAJIWARA and KROUSE (1971), but not with the theoretical model of LI and LIU (2006).

The ${ }^{34} \mathrm{~S}$ content of fluid-mineral pairs suggests that hydrothermal vent fluid $\mathrm{H}_{2} \mathrm{~S}$ and inner lining chalcopyrite reach isotopic equilibrium during precipitation. This result contrasts with previous studies that show disequilibria, and may be attributed to our careful efforts to subsample only the inner 1-2 mm of mono-mineralic chimney linings. This inner lining would have been in contact with active fluid flow, and therefore likely represents mineral precipitating directly from the fluid at the time of sampling.

Results of this study suggest that the sulfur isotopic composition of coexisting fluids and inner-wall chalcopyrite in these hydrothermal vents are not isotopically modified within the samplers or chimney environment, respectively, and can be used as a robust interpretive tool to constrain hydrothermal processes. Time-series observations of a black smoker vent fluid (site Aa) at $9^{\circ} 46.5^{\prime} \mathrm{N}$ EPR by SHANKS (2001) showed that vent fluid $\delta^{34} \mathrm{~S}_{\mathrm{H} 2 \mathrm{~S}}$ increased from $+3 \%$ to $+5 \%$ over the course of three years following a volcanic eruption. Such variability appears to be recorded in sulfide deposits where laser microprobe studies have shown fine-scale $\delta^{34} \mathrm{~S}$ 
variability of up to $4.2 \%$ in across-wall transects in chalcopyrite chimney linings at $21^{\circ} \mathrm{N}$ EPR and $9^{\circ} 50.7^{\prime} \mathrm{N}$ EPR (SHANKS et al., 1998). The results of the present study also support the use of chalcopyrite inner chimney linings in recently inactive chimneys as a record of sulfur source fluctuations during past hydrothermal activity (SHANKS et al., 1998).

\subsection{Multiple sulfur isotopes applied to natural systems}

A number of physical and chemical processes influence the abundance and isotopic composition of sulfur species during the chemical evolution of submarine hot-spring fluids. The major contributors to $\mathrm{H}_{2} \mathrm{~S}$ in vent fluids and associated mineral deposits at unsedimented midocean ridge hydrothermal systems are host rock sulfide, with an average $\delta^{34} \mathrm{~S}$ value of $+0.1 \pm 0.5 \%$ o for mid-ocean ridge basalt (SAKAI et al., 1984), and reduced seawater $\mathrm{SO}_{4}$, with a $\delta^{34} \mathrm{~S}$ value of $+21.0 \pm 0.2 \%$ (REES et al., 1978).

At mid-ocean ridges, black smoker fluid circulation begins in the recharge zone (Fig. 3a), where the heating of seawater to temperatures $>150^{\circ} \mathrm{C}$ results in precipitation of anhydrite due to its retrograde solubility. Precipitation of magnesium hydroxysulfates removes $\mathrm{Mg}$ and $\mathrm{SO}_{4}$. In high temperature reaction zones $\left(\sim 350-400^{\circ} \mathrm{C}\right)$ (Fig. 3b), remaining $\mathrm{SO}_{4}$ is reduced to $\mathrm{H}_{2} \mathrm{~S}$ via oxidation of basaltic pyrrhotite to pyrite, and dissolution of sulfide adds $\mathrm{H}_{2} \mathrm{~S}$ to the fluid, generating $\delta^{34} \mathrm{~S}_{\mathrm{H}_{2} \mathrm{~S}}$ values of approximately +1 to $+1.5 \%$ (SEYFRIED and SHANKS, 1987;

WOODRUFF and SHANKS, 1988). Additional $\mathrm{SO}_{4}$ may be reduced by reaction with Fe-bearing silicates, producing $\delta^{34} \mathrm{~S}_{\mathrm{H}_{2} \mathrm{~S}}$ with values up to $+6.1 \%$ in these samples. The fluid will phase separate into a vapor $\left(\mathrm{Cl}_{\text {fluid }}<\mathrm{Cl}_{\text {seawater }}\right)$ or brine $\left(\mathrm{Cl}_{\text {fluid }}>\mathrm{Cl}_{\text {seawater }}\right)$ phase if it reaches the twophase boundary for seawater $\left(2390^{\circ} \mathrm{C}\right.$ at a seafloor pressure of 250 bars $)$ (Fig. 3d). In the shallow 
subsurface (Fig. 3e) seawater ingress may result in anhydrite deposition and reworking of sulfide deposits via zone refinement. Within the chimney conduit (Fig. 3f) chalcopyrite precipitates.

\subsubsection{Unsedimented mid-ocean ridge}

The effects of the processes discussed above are apparent in the sulfur isotopic composition of vent fluid $\mathrm{H}_{2} \mathrm{~S}$ and chalcopyrite from the bare basalt-hosted SEPR (Fig. 1d; Table 2), where $\delta^{34} \mathrm{~S}$ values fall within the range of +3.7 to $+5.7 \%$. This range of values is observed for vent fluids and deposits in other basalt-hosted systems (SHANKs, 2001) where sulfur sources are limited to a balance between basaltic sulfide and reduced seawater $\mathrm{SO}_{4}$. A two-component mixing model suggests that seawater $\mathrm{SO}_{4}$ reduction contributes $17 \%$ to $27 \%$ of the sulfur in fluid $\mathrm{H}_{2} \mathrm{~S}$ and inner lining chalcopyrite at SEPR. During fluid circulation, reduction of seawater $\mathrm{SO}_{4}$ occurs within the high-temperature reaction zone (Fig. 3b) and possibly also within the shallow subsurface in the upflow zone, if $\mathrm{SO}_{4}$ is re-introduced to the fluid via ambient seawater entrainment (Fig. 3e).

The magnitude of mass-dependent isotope fractionation is proportional to mass differences, and can be predicted based on quantum mechanical equilibrium isotope fractionation theory (UREY, 1947). For sulfur isotopes, ${ }^{33} \mathrm{~S} /{ }^{\beta 2} \mathrm{~S}$ fractionates about half as much as ${ }^{34} \mathrm{~S} /{ }^{32} \mathrm{~S}$, and careful examination of this relationship can provide additional process information. Massdependent fractionation of ${ }^{33} \mathrm{~S}$ can be related to the abundance of ${ }^{34} \mathrm{~S}$ by the relationship $\delta^{33} \mathrm{~S}={ }^{33}$ $\theta \times \delta^{34} \mathrm{~S}$, where ${ }^{33} \theta$ is the thermochemical equilibrium fractionation:

${ }^{33} \theta=\ln \left({ }^{33} \alpha\right) / \ln \left({ }^{34} \alpha\right)$, and 


$$
{ }^{x} \alpha=\frac{{ }^{x} \mathrm{R}_{\mathrm{H}_{2} \mathrm{~S}}}{{ }^{x} \mathrm{R}_{\mathrm{SO}_{4}}}(x=33,34)
$$

As previously discussed in the definition of $\Delta^{33} \mathrm{~S}$, the mass-dependent reference value of ${ }^{33} \theta$ is 0.515. Biological metabolic processes, however, involve multiple fractionation steps and incomplete transfer of S-containing material that result in discernably different mass-dependent fractionation laws and thus are characterized by values of ${ }^{33} \theta$ that are not equal to 0.515 . Accordingly, many biological processes are characterized by non-zero $\Delta^{33} \mathrm{~S}$ values (e.g. FARQUHAR et al., 2003; ONO et al., 2006). For example, several recent studies have documented positive $\Delta^{33} \mathrm{~S}$ values for $\mathrm{H}_{2} \mathrm{~S}$ generated by bacterial $\mathrm{SO}_{4}$ reduction (FARQUHAR et al., 2007) and in a variety of hydrothermal environments thought to have been affected by biological processes, including ancient sedimentary sulfides (ONO et al., 2007), modern hydrothermal sediments (Peters et al., 2010; Peters et al., 2011), S ${ }^{0}$, and barite (KIM et al., 2011; Peters et al., 2011), and secondary pyrite in altered oceanic crust (ONO et al., 2012; RouXEL et al., 2008). The temperature-dependent equilibrium fractionation between two S-containing species can also range in ${ }^{33} \theta$ value, although to a smaller extent than in biological processes (JOHNSTON, 2011; ONO et al., 2006). For example, in hydrothermal systems, equilibrium isotopic exchange between hydrothermal $\mathrm{H}_{2} \mathrm{~S}$ and seawater $\mathrm{SO}_{4}$ can result in $\Delta^{33} \mathrm{~S}$ values up to $+0.04 \%$, while $\mathrm{SO}_{4}$ reduction to $\mathrm{H}_{2} \mathrm{~S}$ would generate near-zero $\Delta^{33} \mathrm{~S}$ values (ONO et al., 2007). Therefore multiple sulfur isotopes may be applied in hydrothermal systems as a tracer to distinguish between sulfide sourced from igneous rock, biogenic pyrite remobilization, seawater $\mathrm{SO}_{4}$ reduction, or magmatic degassing, even when the sources produce indistinguishable $\delta^{34} \mathrm{~S}$ ratios. Furthermore, signatures from equilibrium isotopic exchange between sulfur species may also identify sources and 
important processes (ONO et al., 2007). At SEPR, near-zero $\Delta^{33} \mathrm{~S}$ values (-0.02 to $-0.01 \%$ ) indicate a minimum influence of $\mathrm{SO}_{4}-\mathrm{H}_{2} \mathrm{~S}$ isotope exchange and thus, limited influence of shallow seawater entrainment on SEPR vent fluid sulfur budgets.

\subsubsection{Back-arc mid-ocean ridges}

The sulfur isotope systematics in fluids from the central Eastern Lau Spreading Center in the north (ABE vent) and the Valu Fa Ridge to the south (Tui Malila and Mariner vents) are similar to those at SEPR in that they are also affected by seawater and host rock-derived sulfur inputs. However, host rock composition at Lau includes dacite, andesite, basaltic-andesite, and basalt (FOUQUET et al., 1993; ESCRIG et al., 2009). Studies indicate a general increase in the proportion of felsic rocks with increasing proximity of the spreading center to the active Tofua arc to the South (MARTINEZ and TAYLOR, 2002; EsCRIG et al., 2009; MOTTL et al., 2011). More arc-influenced rocks are potentially enriched in ${ }^{34} \mathrm{~S}$ relative to basalt (TAYLOR, 1986), and greater ${ }^{34} \mathrm{~S}$-enrichment may therefore be anticipated in the southernmost vent fields, closer to the arc. Although the $\delta^{34} \mathrm{~S}$ values of fluid $\mathrm{H}_{2} \mathrm{~S}$ from the Mariner vent field, located furthest to the south, are enriched relative to the $\mathrm{ABE}$ and Tui Malila vent fields, the northernmost $\mathrm{ABE}$ fluids are enriched relative to Tui Malila suggesting heterogeneity in subseafloor crustal composition, or, most likely, variation in the relative contributions of seawater and host-rock derived sulfur sources (Fig. 1c).

The Lau results are generally consistent with a previous study that determined sulfur isotopes in bulk mixed phase sphalerite-chalcopyrite mineralization at several vents, including the inactive White Church deposit, which ranged from $+2.7 \%$ to $+4.6 \%$ (avg. $4.7 \%, \mathrm{n}=10$ ), and the active Vai Lili field, that ranged from $+7.1 \%$ to $+9.3 \%$ (avg. $8.0 \%, \mathrm{n}=5)($ HerZIG et 
al., 1998). The Tui Malila $\delta^{34} \mathrm{~S}$ results group with nearby White Church, while Mariner is more similar to the nearby Vai Lili vent (Fig. 1c).

Hydrothermal activity in back-arc and arc environments can be substantially influenced by the presence of magma bodies that are more oxidizing and silicic relative to mid-ocean ridge environments. Degassing of $\mathrm{SO}_{2}$ from volatile-rich magmas can play a critical role in regulating sulfur speciation in hydrothermal systems (Fig. 3c). Upon cooling below $\sim 400^{\circ} \mathrm{C}, \mathrm{SO}_{2}$ derived from degassing of felsic magma undergoes hydration and disproportionation reactions (GAMO et al., 1997; Holland, 1965; KUSAKABE et al., 2000; REEVES et al., 2011) as follows:

$$
\begin{aligned}
& 3 \mathrm{SO}_{2}+2 \mathrm{H}_{2} \mathrm{O}=2 \mathrm{HSO}_{4}{ }^{-}+\mathrm{S}^{0}+2 \mathrm{H}^{+} \\
& 4 \mathrm{SO}_{2}+4 \mathrm{H}_{2} \mathrm{O}=3 \mathrm{HSO}_{4}{ }^{-}+\mathrm{H}_{2} \mathrm{~S}+3 \mathrm{H}^{+}
\end{aligned}
$$

$\mathrm{S}^{0}$ is more stable under more oxidizing, lower temperature and higher total sulfur conditions while $\mathrm{H}_{2} \mathrm{~S}$ is more stable under more reduced, higher temperature and lower total sulfur conditions (KUSAKABE et al., 2000). Experiments by KUSAKABE et al. (2000) show that the $\mathrm{SO}_{2}$ disproportionation reaction results initially in a $\delta^{34} \mathrm{~S}$ kinetic isotope effect, followed by temperature-dependent equilibrium that produces ${ }^{34}$ S-enriched $\mathrm{HSO}_{4}{ }^{-}$and ${ }^{34} \mathrm{~S}$-depleted $\mathrm{H}_{2} \mathrm{~S}$ (or $\mathrm{S}^{0}$ ) relative to the initial $\mathrm{SO}_{2}$ composition. Chemical species derived from $\mathrm{SO}_{2}$ disproportionation are readily apparent in the chemistry of acid-sulfate fluids formed by the subsurface mixing of magmatic fluids and seawater (Fig. 3g) (REEVES et al., 2011; SEEWALD et $a l$. , in review) and may also be entrained by seawater-derived black smoker fluids undergoing convective circulation (Fig. 3c). 
All of the samples from the Eastern Lau Spreading Center presented in this study are characterized by positive $\delta^{34} \mathrm{~S}$ values and therefore do not show direct evidence for magmatic $\mathrm{SO}_{2}$ disproportionation as a source of reduced sulfur species. However, at the Hine Hina vent field, located $40 \mathrm{~km}$ south of Mariner and closer to the Tonga arc, $\delta^{34} \mathrm{~S}$ values of $-4.0 \%$ and 5.7\%o for mixed phase sphalerite-chalcopyrite and $-3.4 \%$ for chalcopyrite have been attributed to input of isotopically-depleted $\mathrm{H}_{2} \mathrm{~S}$ derived from disproportion of magmatic volatile $\mathrm{SO}_{2}$ (HERZIG et al., 1998).

Similarly, vent fluids and chimney linings from the PACMANUS back arc vent field show a wide spectrum in $\delta^{34} \mathrm{~S}$ values consistent with a significant contribution of magmatic $\mathrm{SO}_{2}$ to some venting fluids. Values of $\delta^{34} \mathrm{~S}$ for fluid $\mathrm{H}_{2} \mathrm{~S}$ and chimney chalcopyrite at Roman Ruins and Roger's Ruins are positive and fall within the range observed at unsedimented mid-ocean ridges (Fig. 1a), while chalcopyrite samples from Satanic Mills are characterized by negative $\delta^{34} \mathrm{~S}$ values, indicating a contribution of sulfur derived by $\mathrm{SO}_{2}$ disproportionation. The presence of magmatic sulfur sources at Satanic Mills confirms previous studies that implicate $\mathrm{SO}_{2}$ disproportionation as an isotopically important contributor to anhydrite (CRADDOCK and BACH, 2010) and vent fluid $\mathrm{H}_{2} \mathrm{~S}$ (CRADDOCK et al., 2010; REEVES et al., 2011) at PACMANUS.

The dominance of mass-dependent thermochemical fractionation revealed by the isotopic measurements in this study $\left(\Delta^{33} \mathrm{~S}=0\right)$ indicates that abiogenic, inorganic mixing processes control sulfur transformations between oceanic crust and seawater in high temperature vent fluids and inner lining chalcopyrite in many cases. In addition, near-zero $\Delta^{33} \mathrm{~S}$ values suggest that isotopic exchange between fluid $\mathrm{H}_{2} \mathrm{~S}$ and $\mathrm{SO}_{4}$ in seawater or anhydrite as reported by ONO et al. (2007) does not significantly impact the back-arc vents in this study. Although the rate of $\mathrm{H}_{2} \mathrm{~S}-\mathrm{SO}_{4}$ isotopic exchange is fast (hours to days) at the low $\mathrm{pH}$ and high temperature 
conditions of SEPR, Lau, and PACMANUS vents (OHмOTO and LASAGA, 1982), black smoker fluids exiting a chimney at $\sim 1-2 \mathrm{~m} / \mathrm{s}$ flow rates may reflect a transport-dominated system that is not significantly affected by isotope exchange with relatively smaller volumes of $\mathrm{SO}_{4}$ that may be encountered within shallow subsurface conduits prior to expulsion of fluids at the seafloor.

Fluid-mineral pairs and $\mathrm{S}^{0}$ precipitates from dacitic-hosted black smokers and acidsulfate fluids at SuSu Knolls and the DESMOS caldera are characterized by negative $\delta^{34} \mathrm{~S}$ values indicating significant ${ }^{34} \mathrm{~S}$-depleted sulfur inputs relative to mantle and host rock $\delta^{34} \mathrm{~S}$ sources (Fig. 1b). These results are consistent with previous studies that have observed negative $\delta^{34} \mathrm{~S}$ signatures in $\mathrm{H}_{2} \mathrm{~S}$ and sulfides in acid sulfate and black smoker fluids and concluded that $\mathrm{SO}_{2}$ disproportionation is occurring at these locations (GAMO et al., 1997; GENA et al., 2006; KIM et al., 2004; REEVES et al., 2011). Although negative $\delta^{34} \mathrm{~S}$ values could be derived from biogenic pyrite in abundant surface sediment less than one kilometer away (HRISCHEVA et al., 2007), the low abundance of $\mathrm{CH}_{4}$ (an expected thermogenic sedimentary alteration product) in acid-sulfate fluids with the most negative $\delta^{34} \mathrm{~S}$ values suggests sedimentary sulfur sources are not signficant. (SEEWALD, et al., submitted).

Measurements of $\Delta^{33} \mathrm{~S}$ provide additional evidence that suggests $\mathrm{SO}_{2}$ disproportion is the source of depleted $\mathrm{H}_{2} \mathrm{~S}$ to the $\mathrm{SuSu}$ Knolls black smokers, as well as North $\mathrm{Su}$ and DESMOS acid-sulfate $\mathrm{S}^{0}$ precipitates and deposits (Fig. 4). The zones of potential biogenic sulfide influence on hydrothermal fluid $\mathrm{H}_{2} \mathrm{~S} \delta^{34} \mathrm{~S}$ and $\Delta^{33} \mathrm{~S}$ values in Figure 4 are based on biogenic pyrite measurements from the Logatchev deep-sea hydrothermal field on the Mid-Atlantic Ridge and the shallow Tyrrhenian Sea island arc off western Italy (Fig. 4a) (PETERS et al., 2010; PETERS et al., 2011). The meshed fields define the equilibrium multiple sulfur isotope compositions of $\mathrm{H}_{2} \mathrm{~S}$ and $\mathrm{SO}_{4}$ (Fig 4a) and $\mathrm{S}^{0}$ and $\mathrm{SO}_{4}$ during disproportionation of magmatic 
$\mathrm{SO}_{2}$ at a range of temperatures (Fig. 4b) using known fractionation factors for ${ }^{33} \mathrm{~S}$ and ${ }^{34} \mathrm{~S}$ and the temperature dependence of ${ }^{33} \theta$ (Онмото and LASAGA, 1982; KUSAKABE et al., 2000; ONO et al., 2007; OTAKE et al., 2008). Although the isotopic composition of magmatic sulfur at $\mathrm{SuSu}$ Knolls is unknown, it is likely ${ }^{34} \mathrm{~S}$-enriched relative to basalt as is observed in island arc volcanic rocks (e.g. TAYLOR, 1986; ALT et al., 1993). Thus, for construction of Figure 4, a value of +5\%o was assumed. In general the calculation is relatively insensitive to small variation in host rock sulfur isotope signature, and does not affect our interpretations. The measured sulfur isotope values for SuSu Knolls $\mathrm{H}_{2} \mathrm{~S}$ plot within or near the meshed disproportionation field (Fig. 4a), supporting $\mathrm{SO}_{2}$ disproportionation as a source for ${ }^{34} \mathrm{~S}$-depleted reduced sulfur in the high temperature black smokers. These results are consistent with other evidence for $\mathrm{SO}_{2}$ disproportionation inputs to SuSu Knolls black smokers, including chimney barite $\delta^{34} \mathrm{~S}_{\mathrm{SO} 4}$ isotope signatures that are ${ }^{34} \mathrm{~S}$-depleted relative to seawater $\mathrm{SO}_{4}$ (KIM et al., 2004). Analogous to the $\mathrm{H}_{2} \mathrm{~S}$ results, sulfur isotope values for low temperature acid-spring fluid $\mathrm{S}^{0}$ plot near the disproportionation field, implicating $\mathrm{SO}_{2}$ disproportionation as the ${ }^{34} \mathrm{~S}$-depleted sulfur source to acid-spring fluids at PACMANUS. Although minor sediment inputs are not precluded, there are no elevations in $\Delta^{33} \mathrm{~S}$ that would support significant input of biogenic sulfide.

\subsubsection{Sedimented mid-ocean ridge}

Hydrothermal fluid interaction with sediments can also impact sulfur isotopes in sediment-covered systems, or in systems with buried sediment. Marine sediments contain ${ }^{34} \mathrm{~S}-$ depleted biogenic sedimentary pyrite with values as low as -50\% (CANFIELD, 2001; CANFIELD and Teske, 1996; KAPlAn et al., 1963; KAPLAN and RitTENBERG, 1964; Sim et al., 2011). In addition to ${ }^{34} \mathrm{~S}$-depletions, bacterial sulfate reduction produces positive $\Delta^{33} \mathrm{~S}$ values relative to 
the starting $\mathrm{SO}_{4}$ (FARQUHAR et al., 2007; FARQUHAR et al., 2003). At temperatures $>100^{\circ} \mathrm{C}$, nonbiological, thermochemical $\mathrm{SO}_{4}$ reduction can also generate abundant $\mathrm{H}_{2} \mathrm{~S}$ (MACHEL et al., 1995).

At sediment-covered hydrothermal systems such as Guaymas Basin, fluids may incorporate ${ }^{34} \mathrm{~S}$-depleted sulfur via dissolution of microbially produced sulfide minerals and/or degradation of S-bearing organic compounds (PETER and SHANKs, 1992; SEEWALD et al., 1994). Due to high surface ocean productivity, the spreading center at Guaymas Basin is overlain by $\sim 500 \mathrm{~m}$ of organic-rich (2\% to 4\% organic carbon) sediment (CALVERT, 1966; VON DAMM et al., 1985) that contains abundant bacteriogenic pyrite (BERNER, 1964; JøRGENSEN et al., 1990). In addition to microbially generated sulfide, potential sulfur sources at Guaymas also include basalt sulfide and sulfide derived from thermochemical $\mathrm{SO}_{4}$ reduction. The sulfur isotopic composition of hydrothermal fluids and minerals from Guaymas Basin show a systematic relationship between the extent of seawater $\mathrm{SO}_{4}$ reduction and the degree of fluid interaction with fresh, lessaltered sediment. In general, fluids with the most positive values of $\delta^{34} \mathrm{~S}$ (Cathedral Hill and Theme Park) contain higher concentrations of $\mathrm{C}_{2+}$ hydrocarbons resulting in lower $\mathrm{CH}_{4} / \mathrm{C}_{2+}$ ratios that are indicative of lower thermal maturity (Table 3, Fig. 5b). Moreover, fluids with low $\mathrm{CH}_{4} / \mathrm{C}_{2+}$ ratios are characterized by relatively depleted values of $\delta^{13} \mathrm{C}_{\text {ethane }}$ (Table 3, Fig. 5a) that also suggest exposure of these hydrocarbons to lower thermal maturity. Thermogenic ethane generally becomes more ${ }^{13} \mathrm{C}$-enriched with increasing thermal maturity of the sedimentary organic source material (LORANT et al., 1998; RoONEY et al., 1995). High abundances of relatively immature $\mathrm{C}_{2+}$ hydrocarbons in the Cathedral Hill and Theme Park fluids suggests interaction with fresh sediment during upflow from high temperature deep-seated reaction zones. Fluid flow through fresh sediment will contact a greater abundance of reactant organic 
compounds and $\mathrm{SO}_{4}$-containing pore fluid, sourced from solid anhydrite under the high temperature reaction conditions (SEEWALD et al., 1994). Ongoing hydrothermal alteration of sediments will deplete organic matter content and progressively seal the walls of fluid conduits, reducing permeability and access to porewater $\mathrm{SO}_{4}$. Thus, relatively ${ }^{34} \mathrm{~S}$-depleted fluid $\mathrm{H}_{2} \mathrm{~S}$ along with the lower abundance of $\mathrm{C}_{2+}$ hydrocarbons and the relatively enriched carbon isotopic composition of ethane in the Rebecca's Roost and Busted Mushroom vent fluids suggest a more mature stage of hydrothermal activity that has extensively altered sediment surrounding fluid flow paths.

Near-zero $\Delta^{33} \mathrm{~S}$ values are observed in all the Guaymas Basin samples despite negative $\delta^{34} \mathrm{~S}$ values for some samples that indicate inputs of diagenetic pyrite (Fig. 1e). This result suggests that there is insufficient incorporation of biogenic pyrite, relative to basalt host-rock input, to elevate vent fluid $\Delta^{33} \mathrm{~S}_{\mathrm{H}_{2} \mathrm{~S}}$ values, or that the diagenetic pyrite mixing endmember may not have elevated $\Delta^{33} \mathrm{~S}$ signatures, in contrast with what is observed in primary biogenic sulfide from other locations. Further interpretation will require multiple sulfur isotopic characterization of Guaymas sediments, diagenetic pyrite, and $\mathrm{SO}_{4}$-containing porewater.

\section{SUMMARY}

Multiple sulfur isotope analysis of chalcopyrite and cubic cubanite from inner lining chimney and corresponding fluid $\mathrm{H}_{2} \mathrm{~S}$ in a spectrum of deep sea hydrothermal systems indicates equilibrium isotope fractionation at temperatures $>270^{\circ} \mathrm{C}$. Enrichments in vent $\mathrm{H}_{2} \mathrm{~S}$ of $>1 \%$ relative to co-existing inner chimney lining metal sulfides were not observed in this study, in contrast with results from previous studies at other localities on the seafloor. This demonstrates that chalcopyrite $\delta^{34} \mathrm{~S}$ signatures can be used to infer sulfur isotope dynamics within active vents, 
including processes occurring below the seafloor. In addition, chalcopyrite chimney linings may record information documenting past episodes of active hydrothermal activity.

Fluid $\mathrm{H}_{2} \mathrm{~S}$, chalcopyrite, and $\mathrm{S}^{0}$ samples from two back arc systems, an unsedimented mid-ocean ridge, and a sedimented mid-ocean ridge show $\Delta^{33} \mathrm{~S}$ values close to zero, which implicates the abiotic processes of $\mathrm{SO}_{4}$ reduction, leaching of host rock $\mathrm{S}$, and $\mathrm{SO}_{2}$ disproportionation as the major contributors to sulfur content in high temperature and acid spring-type hydrothermal fluid circulation, with lesser contributions of biogenic pyrite. At the heavily sedimented Guaymas vent field, fluid flow through fresh sediment supplies an increased quantity of reactant organic compounds that may reduce ${ }^{34} \mathrm{~S}$-enriched $\mathrm{SO}_{4}$, while fluid interaction with more highly-altered sediments results in $\mathrm{H}_{2} \mathrm{~S}$ characterized by a small, but isotopically-significant input of ${ }^{34} \mathrm{~S}$-depleted diagenetic sulfides.

The inclusion of the minor ${ }^{33} \mathrm{~S}$ isotope in hydrothermal vent sulfur isotope studies provides additional information that differentiates between sediment and magmatic sulfur sources that would otherwise be indistinguishable based on $\delta^{34}$ S signatures alone. In black smoker and acid-spring-type fluids at the SuSu Knolls site, $\mathrm{S}^{0}$ deposits and precipitates, vent fluid $\mathrm{H}_{2} \mathrm{~S}$, and inner lining chalcopyrite show similar ${ }^{34} \mathrm{~S}$-depletions relative to mantle isotopic sulfur values, and are not well-explained mixing host rock and biogenically-mediated endmembers, lending further support to $\mathrm{SO}_{2}$ disproportionation as a source of ${ }^{34} \mathrm{~S}$-depleted sulfur in some vents at Manus Basin. 
Table 1. Vent fluid and mineral deposit sample information and chemical compositions.

\begin{tabular}{|c|c|c|c|c|c|c|c|c|c|}
\hline $\begin{array}{l}\text { Location } \\
\text { Vent field: Area: VENT }\end{array}$ & Latitude & Longitude & $\begin{array}{l}\text { Depth } \\
\text { (m) }\end{array}$ & Date & $\begin{array}{l}\mathrm{T}_{\max } \\
\left({ }^{\circ} \mathrm{C}\right)\end{array}$ & $\begin{array}{l}\mathrm{Mg}_{\text {min }} \\
(\mathrm{mm})\end{array}$ & $\begin{array}{c}\mathrm{pH}_{\min } \\
\left(25^{\circ} \mathrm{C}\right)\end{array}$ & $\begin{array}{l}\mathrm{EM} \mathrm{Cl} \\
(\mathrm{mm})\end{array}$ & $\begin{array}{c}\mathrm{EM} \Sigma \mathrm{H}_{2} \mathrm{~S} \\
(\mathrm{mM})\end{array}$ \\
\hline \multicolumn{10}{|l|}{ Manus Basin ${ }^{\mathrm{ab}}$} \\
\hline \multicolumn{10}{|l|}{ PACMANUS: Roman Ruins } \\
\hline $\operatorname{RMR} 1\left(314^{\circ} \mathrm{C}\right)$ & $3^{\circ} 43.233^{\prime} \mathrm{S}$ & $151^{\circ} 40.509^{\prime} \mathrm{E}$ & 1677 & 2 Aug 2006 & 314 & 7.26 & 2.3 & 632 & 7.5 \\
\hline RMR3 $\left(278^{\circ} \mathrm{C}\right)$ & $3^{\circ} 43.284^{\prime} \mathrm{S}$ & $151^{\circ} 40.470^{\prime} \mathrm{E}$ & 1660 & 7 Aug 2006 & 278 & 6.39 & 2.5 & 731 & 4.4 \\
\hline RMR4 $\left(341^{\circ} \mathrm{C}\right)$ & $3^{\circ} 43.231^{\prime} \mathrm{S}$ & $151^{\circ} 40.492^{\prime} \mathrm{E}$ & 1680 & 17 Aug 2006 & 341 & 3.63 & 2.6 & 658 & 6.8 \\
\hline \multicolumn{10}{|l|}{ PACMANUS: Roger's Ruins } \\
\hline $\operatorname{RGR} 1\left(320^{\circ} \mathrm{C}\right)$ & $3^{\circ} 43.284^{\prime} \mathrm{S}$ & $151^{\circ} 40.470^{\prime} \mathrm{E}$ & 1660 & 7 Aug 2006 & 320 & 4.24 & 2.7 & 648 & 3.6 \\
\hline \multicolumn{10}{|l|}{ PACMANUS: Satanic Mills } \\
\hline $\operatorname{SMl}\left(295^{\circ} \mathrm{C}\right)$ & $3^{\circ} 43.603^{\prime} \mathrm{S}$ & $151^{\circ} 40.322^{\prime} \mathrm{E}$ & 1685 & 3 Aug 2006 & 295 & 8.16 & 2.6 & 517 & 9.4 \\
\hline $\mathrm{SM} 3\left(288^{\circ} \mathrm{C}\right)$ & $3^{\circ} 43.589^{\prime} \mathrm{S}$ & $151^{\circ} 40.324^{\prime} \mathrm{E}$ & 1682 & 8 Aug 2006 & 288 & 9.72 & 2.5 & 503 & 10.2 \\
\hline \multicolumn{10}{|l|}{ Su Su Knolls: North Su } \\
\hline NS2 $\left(215^{\circ} \mathrm{C}\right)$ & $3^{\circ} 48.072 ' \mathrm{~S}$ & $151^{\circ} 06.026^{\prime} \mathrm{E}$ & 1257 & 16 Aug 2006 & 215 & 39.2 & 0.87 & 152 & b.d. \\
\hline $\mathrm{NS} 3\left(300^{\circ} \mathrm{C}\right)$ & $3^{\circ} 48.011 ' \mathrm{~S}$ & $151^{\circ} 06.054^{\prime} \mathrm{E}$ & 1157 & 18 Aug 2006 & 300 & 1.62 & 3.4 & 674 & 3.4 \\
\hline NS5 $\left(296^{\circ} \mathrm{C}\right)$ & $3^{\circ} 48.000^{\prime} \mathrm{S}$ & $151^{\circ} 06.0577^{\prime} \mathrm{E}$ & 1153 & 22 Aug 2006 & 296 & 7.42 & 3.2 & 550 & 6.6 \\
\hline \multicolumn{10}{|l|}{ Su Su Knolls: South Su } \\
\hline $\mathrm{SS} 2\left(288^{\circ} \mathrm{C}\right)$ & $3^{\circ} 48.566^{\prime} \mathrm{S}$ & $152^{\circ} 6.323^{\prime} \mathrm{E}$ & 1327 & 19 Aug 2006 & 288 & 6.77 & 2.7 & 609 & 8.1 \\
\hline \multicolumn{10}{|l|}{ DESMOS } \\
\hline $\mathrm{D} 1\left(117^{\circ} \mathrm{C}\right)$ & $3^{\circ} 41.488^{\prime} \mathrm{S}$ & $151^{\circ} 52.715^{\prime} \mathrm{E}$ & 1908 & 15 Aug 2006 & 117 & 44.9 & 1.0 & 209 & 0.03 \\
\hline \multicolumn{10}{|l|}{ Lau Basin ${ }^{\mathrm{b}}$} \\
\hline ABE North $\left(312^{\circ} \mathrm{C}\right)$ & $20^{\circ} 45.8^{\prime} \mathrm{S}$ & $176^{\circ} 11.5^{\prime} \mathrm{W}$ & 2139 & 04 Jul 2009 & 312 & 2.05 & 3.9 & n.m. ${ }^{\mathrm{c}}$ & 3.9 \\
\hline Tui Malila $\left(315^{\circ} \mathrm{C}\right)$ & $21^{\circ} 59.35^{\prime} \mathrm{S}$ & $176^{\circ} 34.06^{\prime} \mathrm{W}$ & 1870 & 23 Jun 2009 & 315 & 1.08 & 3.8 & n.m. & 2.8 \\
\hline Mariner $\left(338^{\circ} \mathrm{C}\right)$ & $22^{\circ} 10.82^{\prime} \mathrm{S}$ & $176^{\circ} 36.09^{\prime} \mathrm{W}$ & 1910 & 17 Jun 2009 & 388 & 3.19 & 2.3 & n.m. & 8.9 \\
\hline \multicolumn{10}{|l|}{ Southern EPR ${ }^{\mathrm{d}}$} \\
\hline $\operatorname{Simon}\left(336^{\circ} \mathrm{C}\right)$ & $21^{\circ} 26.508^{\prime} \mathrm{S}$ & $114^{\circ} 16.659^{\prime} \mathrm{W}$ & 2799 & 18 Oct 1998 & 336 & 3.37 & 3.4 & 751 & 3.5 \\
\hline Wally $\left(314^{\circ} \mathrm{C}\right)$ & $17^{\circ} 37.790^{\prime} \mathrm{S}$ & $113^{\circ} 15.337^{\prime} \mathrm{W}$ & 2596 & 27 Oct 1998 & 314 & 3.08 & 3.4 & 751 & 6.4 \\
\hline Hobbes $\left(347^{\circ} \mathrm{C}\right)$ & $17^{\circ} 35.223^{\prime} \mathrm{S}$ & $113^{\circ} 14.741^{\prime} \mathrm{W}$ & 2595 & 30 Oct 1998 & 347 & 2.40 & 3.2 & 482 & 9.0 \\
\hline \multicolumn{10}{|l|}{ Guaymas Basin $^{\mathrm{b}}$} \\
\hline Busted Mushroom $\left(302^{\circ} \mathrm{C}\right)$ & $27^{\circ} 00.65^{\prime} \mathrm{N}$ & $111^{\circ} 24.4^{\prime} \mathrm{W}$ & 1998 & 5 Mar 2003 & 302 & 1.50 & 6.6 & 596 & 6.9 \\
\hline Rebecca's Roost $\left(299^{\circ} \mathrm{C}\right)$ & $27^{\circ} 00.671^{\prime} \mathrm{N}$ & $111^{\circ} 24.414^{\prime} \mathrm{W}$ & 1990 & 22 Oct 2008 & 299 & 3.12 & 6.1 & 600 & 8.0 \\
\hline Cathedral Hill $\left(169^{\circ} \mathrm{C}\right)$ & $27^{\circ} 00.706^{\prime} \mathrm{N}$ & $111^{\circ} 24.268^{\prime} \mathrm{W}$ & 2011 & 6 Mar 2003 & 169 & 24.7 & 6.2 & 592 & 7.7 \\
\hline Theme Park $\left(249^{\circ} \mathrm{C}\right)$ & $27^{\circ} 00.708^{\prime} \mathrm{N}$ & $111^{\circ} 24.305^{\prime} \mathrm{W}$ & 2014 & 18 Oct 2008 & 249 & 3.46 & 5.7 & 599 & 6.8 \\
\hline \multicolumn{4}{|c|}{$\begin{array}{l}\mathrm{mm}, \mathrm{mmol} / \mathrm{kg} \text { fluid; } \mathrm{mM}, \mathrm{mmol} / \mathrm{L} \text { fluid } \\
{ }^{\mathrm{a}} \mathrm{PACMANUS} \mathrm{Mg}_{\min } \mathrm{pH}_{\operatorname{mix}} \text { endmember } \mathrm{Cl} \text { and endmember } \Sigma \mathrm{H}_{2} \mathrm{~S} \text { from Reeves et al. (2011). }\end{array}$} & (2011) & & & & & \\
\hline
\end{tabular}


Table 2. Multiple-S isotope compositions of modern hydrothermal vent fluid $\mathrm{H}_{2} \mathrm{~S}$, coexisting chalcopyrite and cubic cubanite chimney linings, and acid spring $\mathrm{S}^{0}$ particles and deposits, normalized to VCDT.

\begin{tabular}{|c|c|c|c|c|c|c|c|c|c|c|c|c|}
\hline $\begin{array}{l}\text { Location: Vent field } \\
\text { Area: VENT }\left(\mathrm{T}_{\max }\right)\end{array}$ & Sample $^{\mathrm{a}}$ & Type $^{b}$ & $\begin{array}{l}\delta^{33} \mathrm{~S} \\
(\%)\end{array}$ & $\begin{array}{l} \pm 1 \sigma \\
(\%)\end{array}$ & $\begin{array}{l}\delta^{34} \mathrm{~S} \\
(\%)\end{array}$ & $\begin{array}{l} \pm 1 \sigma^{\mathrm{c}} \\
(\%)\end{array}$ & $\begin{array}{l}\delta^{36} \mathrm{~S} \\
(\%)\end{array}$ & $\begin{array}{l} \pm 1 \sigma \\
(\%)\end{array}$ & $\begin{array}{l}\Delta^{33} S \\
(\%)\end{array}$ & $\begin{array}{l} \pm 1 \sigma \\
(\%)\end{array}$ & $\begin{array}{l}\Delta^{36} S \\
(\%)) \\
\end{array}$ & $\begin{array}{l} \pm 1 \sigma \\
(\%)\end{array}$ \\
\hline \multicolumn{13}{|l|}{ Manus Basin } \\
\hline \multicolumn{13}{|l|}{ PACMANUS } \\
\hline \multicolumn{13}{|l|}{ Roman Ruins } \\
\hline \multirow[t]{2}{*}{$\operatorname{RMR} 1\left(314^{\circ} \mathrm{C}\right)$} & J2-208-IGT8 & $\mathrm{H}_{2} \mathrm{~S}(\mathrm{aq})$ & 1.505 & 0.023 & 2.991 & 0.014 & 5.47 & 0.15 & -0.033 & 0.023 & 0.014 & 0.133 \\
\hline & J2-208-1-R1 & cpy & 1.443 & 0.006 & 2.818 & 0.015 & 5.13 & 0.11 & -0.006 & 0.006 & 0.000 & 0.103 \\
\hline \multirow[t]{2}{*}{$\mathrm{RMR} 3\left(278^{\circ} \mathrm{C}\right)$} & J2-213-IGT7 & $\mathrm{H}_{2} \mathrm{~S}(\mathrm{aq})$ & 0.714 & 0.027 & 1.392 & 0.021 & 2.26 & 0.20 & 0.001 & 0.027 & -0.149 & 0.199 \\
\hline & J2-213-3-R1A & cpy & 1.321 & 0.010 & 2.557 & 0.005 & 4.59 & 0.08 & 0.007 & 0.010 & -0.041 & 0.085 \\
\hline \multirow{3}{*}{$\operatorname{RMR} 4\left(341^{\circ} \mathrm{C}\right)$} & J2-222-IGT1 & $\mathrm{H}_{2} \mathrm{~S}(\mathrm{aq})$ & 1.977 & 0.013 & 3.851 & 0.015 & 7.04 & 0.09 & -0.003 & 0.013 & -0.052 & 0.085 \\
\hline & J2-222-4-R1-SO & cpy & 1.851 & 0.012 & 3.610 & 0.009 & 6.56 & 0.04 & -0.006 & 0.012 & -0.070 & 0.050 \\
\hline & $\mathrm{J} 2-222-4-\mathrm{R} 1-\mathrm{SP}$ & cpy & 1.982 & 0.012 & 3.896 & 0.010 & 7.13 & 0.09 & -0.021 & 0.015 & -0.042 & 0.092 \\
\hline \multicolumn{13}{|l|}{ Roger's Ruins } \\
\hline RGR1 $\left(320^{\circ} \mathrm{C}\right)$ & J2-213-1GT3 & $\mathrm{H}_{2} \mathrm{~S}(\mathrm{aq})$ & 2.792 & 0.019 & 5.411 & 0.011 & 9.92 & 0.13 & 0.012 & 0.019 & -0.091 & 0.142 \\
\hline & $\mathrm{J} 2-213-6-\mathrm{R} 1$ & cpy & 2.912 & 0.007 & 5.640 & 0.010 & 10.43 & 0.07 & 0.008 & 0.007 & -0.058 & 0.068 \\
\hline Satanic Mills & & & & & & & & & & & & \\
\hline $\operatorname{SM} 1\left(295^{\circ} \mathrm{C}\right)$ & J2-209-1GT6 & $\mathrm{H}_{2} \mathrm{~S}(\mathrm{aq})$ & 0.283 & 0.009 & 0.545 & 0.010 & 0.76 & 0.11 & 0.007 & 0.009 & -0.033 & 0.116 \\
\hline & J2-209-1-R1 (1) & cpy & -0.383 & 0.012 & -0.740 & 0.005 & -1.65 & 0.07 & -0.003 & 0.012 & -0.007 & 0.079 \\
\hline & $\mathrm{J} 2-209-1-\mathrm{R} 1$ (2) (repl) & cpy & -0.177 & 0.011 & -0.368 & 0.005 & -0.94 & 0.06 & 0.014 & 0.011 & -0.010 & 0.061 \\
\hline & J2-209-1-R1 (2) (rep2) & cpy & -0.391 & 0.010 & -0.792 & 0.005 & -1.77 & 0.04 & 0.018 & 0.010 & -0.029 & 0.045 \\
\hline SM3 $\left(288^{\circ} \mathrm{C}\right)$ & J2-214-1GT8 & $\mathrm{H}_{2} \mathrm{~S}(\mathrm{aq})$ & 0.431 & 0.011 & 0.838 & 0.014 & 1.27 & 0.09 & 0.005 & 0.011 & -0.083 & 0.092 \\
\hline & J2-214-3-R1A (rep1) & cpy & 0.255 & 0.012 & 0.498 & 0.025 & 0.69 & 0.05 & 0.000 & 0.012 & -0.029 & 0.062 \\
\hline & J2-214-3-R1A (rep2) & cpy & 0.222 & 0.008 & 0.431 & 0.006 & 0.54 & 0.06 & 0.002 & 0.008 & -0.045 & 0.053 \\
\hline Su Su Knolls & & & & & & & & & & & & \\
\hline North Su & & & & & & & & & & & & \\
\hline $\mathrm{NS} 2\left(215^{\circ} \mathrm{C}\right)$ & J2-221-IGT5 & $\mathrm{S}^{0}$ particles & -1.830 & 0.016 & -3.568 & 0.008 & -7.08 & 0.05 & -0.019 & 0.016 & -0.061 & 0.055 \\
\hline & J2-221-IGT6 & $\mathrm{S}^{0}$ particles & -0.762 & 0.013 & -1.476 & 0.020 & -3.06 & 0.07 & 0.001 & 0.013 & -0.019 & 0.074 \\
\hline & J2-221-M2 & $\mathrm{S}^{0}$ particles & -0.716 & 0.012 & -1.395 & 0.007 & -2.92 & 0.06 & -0.010 & 0.012 & -0.024 & 0.069 \\
\hline & J2-221-13-R1A & $\mathrm{S}^{0}$ deposit & -1.885 & 0.011 & -3.700 & 0.010 & -7.26 & 0.08 & 0.014 & 0.012 & -0.025 & 0.062 \\
\hline & J2-221-13-R1B & $\mathrm{S}^{0}$ deposit & -1.278 & 0.010 & -2.480 & 0.010 & -4.91 & 0.10 & -0.003 & 0.012 & 0.025 & 0.089 \\
\hline NS3 $\left(300^{\circ} \mathrm{C}\right)$ & J2-223-IGT7 & $\mathrm{H}_{2} \mathrm{~S}(\mathrm{aq})$ & -2.552 & 0.027 & -4.887 & 0.017 & -9.70 & 0.19 & -0.035 & 0.027 & -0.178 & 0.180 \\
\hline & J2-223-1-RIA (1) & cpy & -2.278 & 0.008 & -4.431 & 0.006 & -8.70 & 0.10 & 0.005 & 0.008 & -0.024 & 0.098 \\
\hline & $\mathrm{J} 2-223-1-\mathrm{R} 1 \mathrm{~A}(2)$ & cpy & -2.124 & 0.013 & -4.131 & 0.008 & -8.08 & 0.09 & 0.004 & 0.013 & 0.010 & 0.081 \\
\hline $\operatorname{NS} 5\left(296^{\circ} \mathrm{C}\right)$ & J2-227-IGT1 & $\mathrm{H}_{2} \mathrm{~S}(\mathrm{aq})$ & -2.572 & 0.011 & -5.016 & 0.012 & -9.76 & 0.07 & 0.011 & 0.011 & 0.012 & 0.065 \\
\hline & $\mathrm{J} 2-227-\mathrm{IGT} 2$ & $\mathrm{H}_{2} \mathrm{~S}(\mathrm{aq})$ & -2.295 & 0.011 & -4.459 & 0.008 & -8.84 & 0.08 & 0.002 & 0.011 & -0.128 & 0.079 \\
\hline & J2-227-10-R1-TS & cpy & -2.829 & 0.018 & -5.477 & 0.008 & -10.68 & 0.09 & -0.008 & 0.018 & -0.033 & 0.083 \\
\hline South Su & & & & & & & & & & & & \\
\hline $\mathrm{SS} 2\left(288^{\circ} \mathrm{C}\right)$ & J2-224-IGT1 & $\mathrm{H}_{2} \mathrm{~S}(\mathrm{aq})$ & -1.404 & 0.012 & -2.746 & 0.007 & -5.55 & 0.06 & 0.010 & 0.012 & -0.102 & 0.053 \\
\hline & $\mathrm{J} 2-224-12-\mathrm{R} 1$ & cpy & -1.495 & 0.008 & -2.925 & 0.010 & -5.85 & 0.08 & 0.012 & 0.008 & -0.058 & 0.073 \\
\hline DESMOS & & & & & & & & & & & & \\
\hline $\mathrm{D} 1\left(117^{\circ} \mathrm{C}\right)$ & J2-220-IGT2 & $\mathrm{S}^{0}$ particles & -2.689 & 0.010 & -5.197 & 0.005 & -10.12 & 0.05 & -0.012 & 0.010 & -0.008 & 0.056 \\
\hline & J2-220-M4 (rep1) & $\mathrm{S}^{0}$ particles & -2.474 & 0.012 & -4.776 & 0.005 & -9.31 & 0.08 & -0.014 & 0.012 & 0.000 & 0.084 \\
\hline & J2-220-M4 (rep2) & $\mathrm{S}^{0}$ particles & -3.967 & 0.014 & -7.686 & 0.012 & -14.88 & 0.06 & -0.009 & 0.014 & -0.031 & 0.058 \\
\hline & $\mathrm{J} 2-220-11-\mathrm{R} 1$ & $\mathrm{~S}^{0}$ deposit & -3.932 & 0.009 & -7.640 & 0.010 & -14.70 & 0.09 & -0.005 & 0.012 & 0.034 & 0.071 \\
\hline & $\mathrm{J} 2-220-5-\mathrm{R} 2$ & $\mathrm{~S}^{0}$ deposit & -4.238 & 0.010 & -8.190 & 0.010 & -15.75 & 0.09 & -0.025 & 0.013 & 0.038 & 0.089 \\
\hline Lau Basin & & & & & & & & & & & & \\
\hline $\mathrm{ABE}$ North $\left(312^{\circ} \mathrm{C}\right)$ & J2-449-IGT6 & $\mathrm{H}_{2} \mathrm{~S}(\mathrm{aq})$ & 2.271 & 0.011 & 4.417 & 0.009 & 8.24 & 0.08 & -0.001 & 0.011 & 0.074 & 0.089 \\
\hline & J2-449-6-R1 (1) & cpy, trace pyr & 1.983 & 0.008 & 3.861 & 0.007 & 7.10 & 0.08 & -0.003 & 0.008 & -0.006 & 0.076 \\
\hline & J2-449-6-R1 (2) & cpy, trace pyr & 2.143 & 0.011 & 4.198 & 0.017 & 7.73 & 0.11 & -0.016 & 0.011 & -0.021 & 0.102 \\
\hline & J2-449-6-R1 (3) & cpy, trace pyr & 2.090 & 0.011 & 4.080 & 0.005 & 7.59 & 0.06 & -0.009 & 0.011 & 0.065 & 0.063 \\
\hline Tui Malila $\left(315^{\circ} \mathrm{C}\right)$ & J2-442-IGT4 & $\mathrm{H}_{2} \mathrm{~S}(\mathrm{aq})$ & 1.227 & 0.014 & 2.414 & 0.013 & 4.26 & 0.16 & -0.014 & 0.014 & -0.097 & 0.161 \\
\hline & J2-442-4-R2 (1) (rep1) & cpy, trace pyr & 1.803 & 0.013 & 3.516 & 0.006 & 6.39 & 0.06 & -0.005 & 0.013 & -0.059 & 0.058 \\
\hline & J2-442-4-R2 (1) (rep2) & cpy, trace pyr & 1.799 & 0.012 & 3.517 & 0.008 & 6.43 & 0.06 & -0.010 & 0.012 & -0.024 & 0.069 \\
\hline & $\mathrm{J} 2-442-4-\mathrm{R} 2(2)$ & cpy, trace pyr & 1.634 & 0.016 & 3.180 & 0.016 & 5.84 & 0.11 & -0.002 & 0.016 & 0.026 & 0.111 \\
\hline Mariner $\left(338^{\circ} \mathrm{C}\right)$ & J2-437-IGT5 (rep1) & $\mathrm{H}_{2} \mathrm{~S}(\mathrm{aq})$ & 3.156 & 0.019 & 6.108 & 0.010 & 11.49 & 0.04 & 0.014 & 0.019 & 0.110 & 0.047 \\
\hline & J2-437-IGT5 (rep2) & $\mathrm{H}_{2} \mathrm{~S}(\mathrm{aq})$ & 3.072 & 0.021 & 5.938 & 0.017 & 11.15 & 0.06 & 0.017 & 0.021 & 0.091 & 0.074 \\
\hline & J2-437-IGT6 & $\mathrm{H}_{2} \mathrm{~S}(\mathrm{aq})$ & 3.039 & 0.016 & 5.944 & 0.005 & 11.01 & 0.05 & -0.019 & 0.016 & -0.061 & 0.055 \\
\hline & $\mathrm{J} 2-437-3-\mathrm{R} 3$ & cpy & 2.737 & 0.007 & 5.299 & 0.006 & 9.84 & 0.08 & 0.011 & 0.007 & -0.008 & 0.073 \\
\hline Southern EPR & & & & & & & & & & & & \\
\hline Simon $\left(336^{\circ} \mathrm{C}\right)$ & $3288-1 \mathrm{C}$ & $\mathrm{H}_{2} \mathrm{~S}(\mathrm{aq})$ & 2.584 & 0.014 & 5.042 & 0.005 & 9.46 & 0.06 & -0.010 & 0.014 & 0.109 & 0.057 \\
\hline & $3288-5-1 \mathrm{a}$ & cpy & 1.905 & 0.011 & 3.709 & 0.017 & 6.78 & 0.09 & -0.003 & 0.011 & -0.037 & 0.095 \\
\hline Wally $\left(314^{\circ} \mathrm{C}\right)$ & $3296-12 \mathrm{C}$ & $\mathrm{H}_{2} \mathrm{~S}(\mathrm{aq})$ & 2.842 & 0.016 & 5.538 & 0.008 & 10.39 & 0.05 & -0.019 & 0.016 & -0.061 & 0.055 \\
\hline & $3296-4$ & cpy & 2.376 & 0.012 & 4.644 & 0.006 & 8.65 & 0.03 & -0.013 & 0.012 & 0.055 & 0.029 \\
\hline Hobbes $\left(347^{\circ} \mathrm{C}\right)$ & $3299-9 \mathrm{C}$ & $\mathrm{H}_{2} \mathrm{~S}(\mathrm{aq})$ & 2.927 & 0.012 & 5.707 & 0.009 & 10.68 & 0.07 & -0.010 & 0.012 & -0.024 & 0.069 \\
\hline & $3299-6-1 \mathrm{e}$ & cpy & 2.404 & 0.013 & 4.697 & 0.011 & 8.70 & 0.08 & -0.012 & 0.013 & 0.006 & 0.076 \\
\hline Guaymas Basin & & & & & & & & & & & & \\
\hline Busted Mushroom $\left(302^{\circ} \mathrm{C}\right)$ & IGT-T525-4-H ${ }_{2} \mathrm{~S} 1$ & $\mathrm{H}_{2} \mathrm{~S}(\mathrm{aq})$ & -0.238 & 0.012 & -0.419 & 0.010 & -1.04 & 0.06 & -0.021 & 0.012 & -0.013 & 0.060 \\
\hline & T591-TA4-28a & icb & -0.699 & 0.010 & -1.350 & 0.011 & -2.79 & 0.06 & -0.003 & 0.010 & 0.004 & 0.055 \\
\hline Rebecca's Roost $\left(299^{\circ} \mathrm{C}\right)$ & 4462-IGT1- $\mathrm{H}_{2} \mathrm{~S} 1$ & $\mathrm{H}_{2} \mathrm{~S}(\mathrm{aq})$ & -0.303 & 0.008 & -0.574 & 0.007 & -1.32 & 0.09 & -0.006 & 0.008 & 0.003 & 0.096 \\
\hline Cathedral Hill $\left(169^{\circ} \mathrm{C}\right)$ & IGT-T526-4- $\mathrm{H}_{2} \mathrm{~S} 1$ & $\mathrm{H}_{2} \mathrm{~S}(\mathrm{aq})$ & 1.178 & 0.012 & 2.315 & 0.006 & 4.19 & 0.05 & -0.013 & 0.012 & 0.022 & 0.057 \\
\hline Theme Park $\left(249^{\circ} \mathrm{C}\right)$ & 4458-IGT1- $\mathrm{H}_{2} \mathrm{~S} 2$ (rep1) & $\mathrm{H}_{2} \mathrm{~S}(\mathrm{aq})$ & 2.130 & 0.006 & 4.153 & 0.008 & 7.68 & 0.05 & -0.006 & 0.006 & 0.015 & 0.054 \\
\hline & 4458-IGT1- $\mathrm{H}_{2} \mathrm{~S} 2$ (rep2) & $\mathrm{H}_{2} \mathrm{~S}(\mathrm{aq})$ & 2.430 & 0.012 & 4.749 & 0.006 & 8.86 & 0.06 & -0.013 & 0.012 & 0.059 & 0.064 \\
\hline
\end{tabular}


Table 3. Endmember hydrocarbon abundances and carbon isotopic composition at the Guaymas Basin hydrothermal system in 2003.

\begin{tabular}{lcccccc}
\hline Vent field $\left(\mathrm{T}_{\max }\right)$ & $\begin{array}{c}\text { Endmember } \\
\mathrm{CH}_{4} \\
(\mathrm{mM})\end{array}$ & $\begin{array}{c}\text { Endmember } \\
\text { ethane } \\
(\mathrm{mm})\end{array}$ & $\begin{array}{c}\text { Endmember } \\
\text { propane } \\
(\mathrm{mm})\end{array}$ & $\begin{array}{c}\text { Endmember } \\
\text { n-butane } \\
(\mathrm{mm})\end{array}$ & $\begin{array}{c}\text { Endmember } \\
\mathrm{CH}_{4} / \mathrm{C}_{2+} \text { ratio }\end{array}$ & $\begin{array}{c}\text { Measured } \\
\delta^{13} \mathrm{C}_{\text {ethane }} \\
(\%)\end{array}$ \\
\hline Busted Mushroom $\left(302^{\circ} \mathrm{C}\right)$ & 57 & 450 & 34 & 1.7 & 118 & -11.6 \\
Rebecca's Roost $\left(299^{\circ} \mathrm{C}\right)$ & 54 & 444 & 31 & 1.4 & 112 & -11.8 \\
Cathedral Hill $\left(169^{\circ} \mathrm{C}\right)$ & 40 & 412 & 95 & 33 & 74 & -15.5 \\
Theme Park $\left(249^{\circ} \mathrm{C}\right)$ & 41 & 733 & 282 & 116 & 36 & -18.8 \\
\hline
\end{tabular}



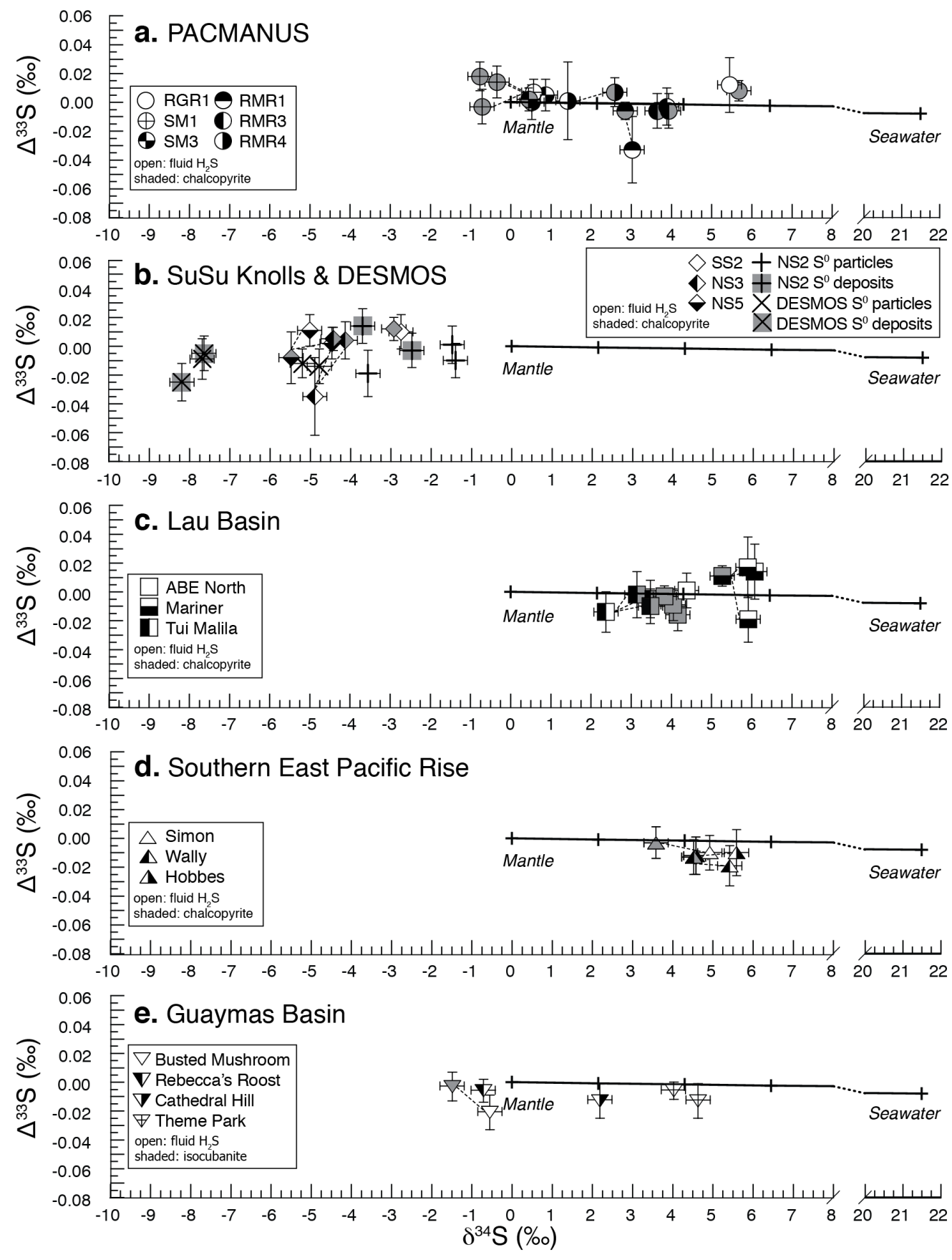

Figure 1. Plot of $\delta^{34} \mathrm{~S}$ ratios versus $\Delta^{33} \mathrm{~S}$ for $\mathrm{H}_{2} \mathrm{~S}$ (open symbols) and corresponding mineral lining (shaded symbols) from PACMANUS (a), SuSu Knolls (b), Lau Basin (c), SEPR (d), Guaymas Basin (e). $\delta^{34} \mathrm{~S}$ ratios are also plotted versus $\Delta^{33} \mathrm{~S}$ for $\mathrm{S}^{0}$ at $\mathrm{SuSu}$ Knolls and DESMOS (b). Dotted lines connect fluid-mineral pairs. The mixing line between mantle sulfur and seawater $\mathrm{SO}_{4}$ is represented by black solid line, with relative mass fraction in 0.1 increments marked with crosses. 


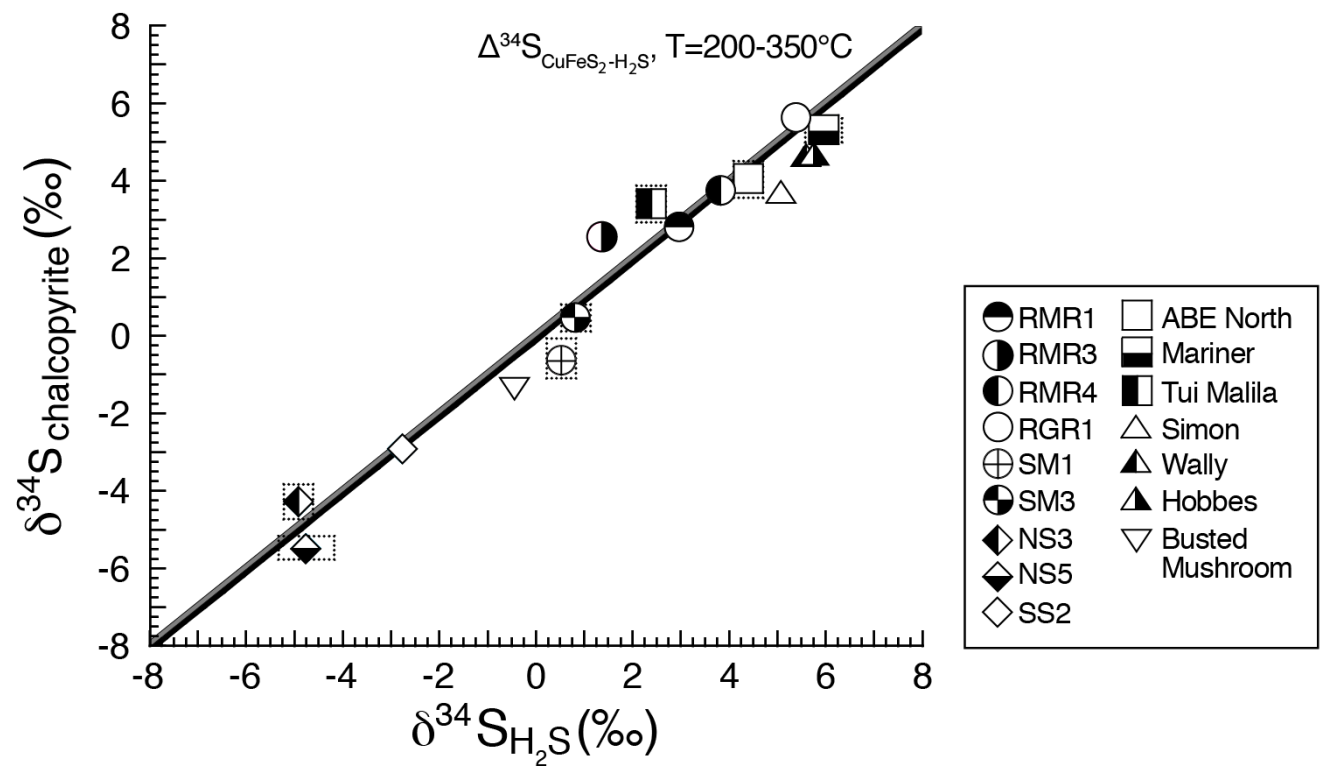

Figure 2. Plot of $\delta^{34} \mathrm{~S}_{\mathrm{H}_{2} \mathrm{~S}}$ versus $\delta^{34} \mathrm{~S}_{\text {chalcopyrite }}$ for mineral-solid pairs from black smokers at PACMANUS (circles), SuSu Knolls (diamonds), Lau Basin (squares), SEPR (up-pointing triangles), and Guaymas Basin (down-pointing triangle). Dotted boxes indicate the range of values for replicate samples from a given location; in these cases the symbol represents the average value. The fractionation factors determined experimentally by KAJIWARA and KROUSE (1971) and calculated by LI and LIU (2006) are represented by black and gray lines, respectively. 


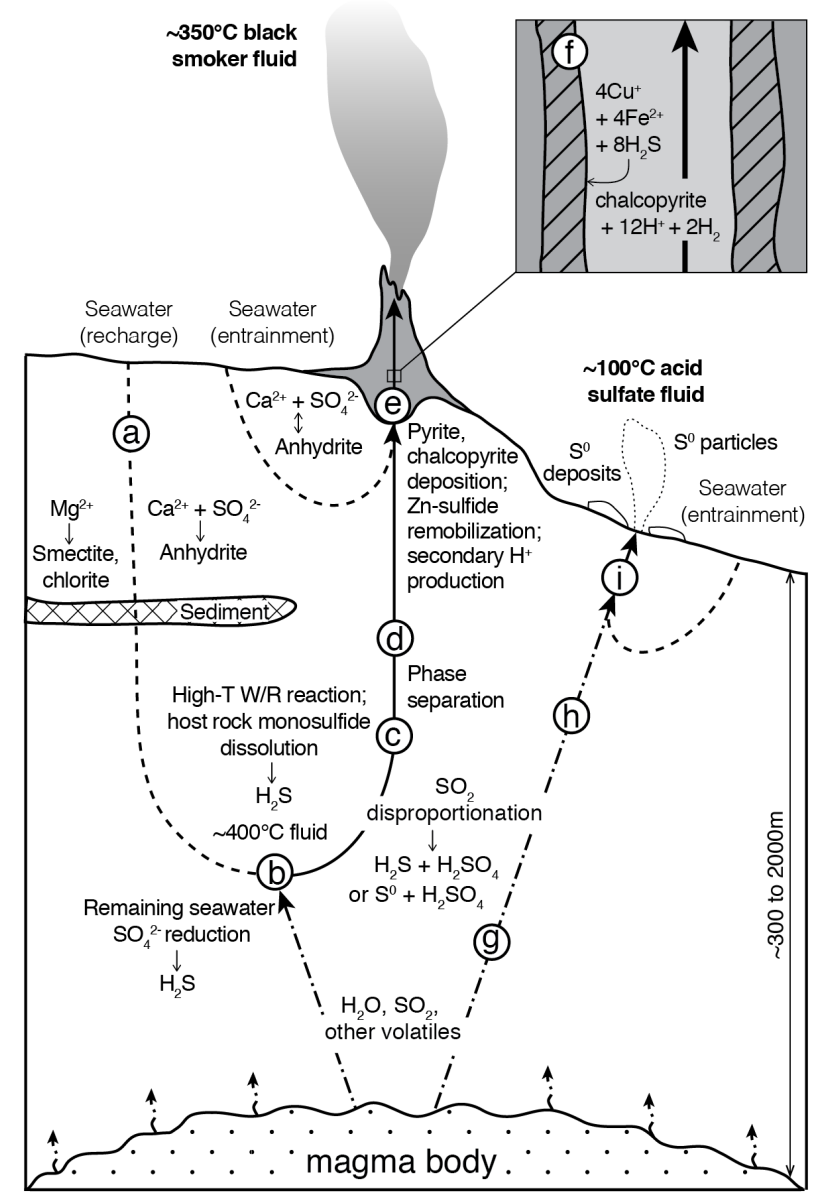

Figure 3. Summary of processes affecting sulfur isotope ratios in black smoker and acid-sulfate fluids (see text). 

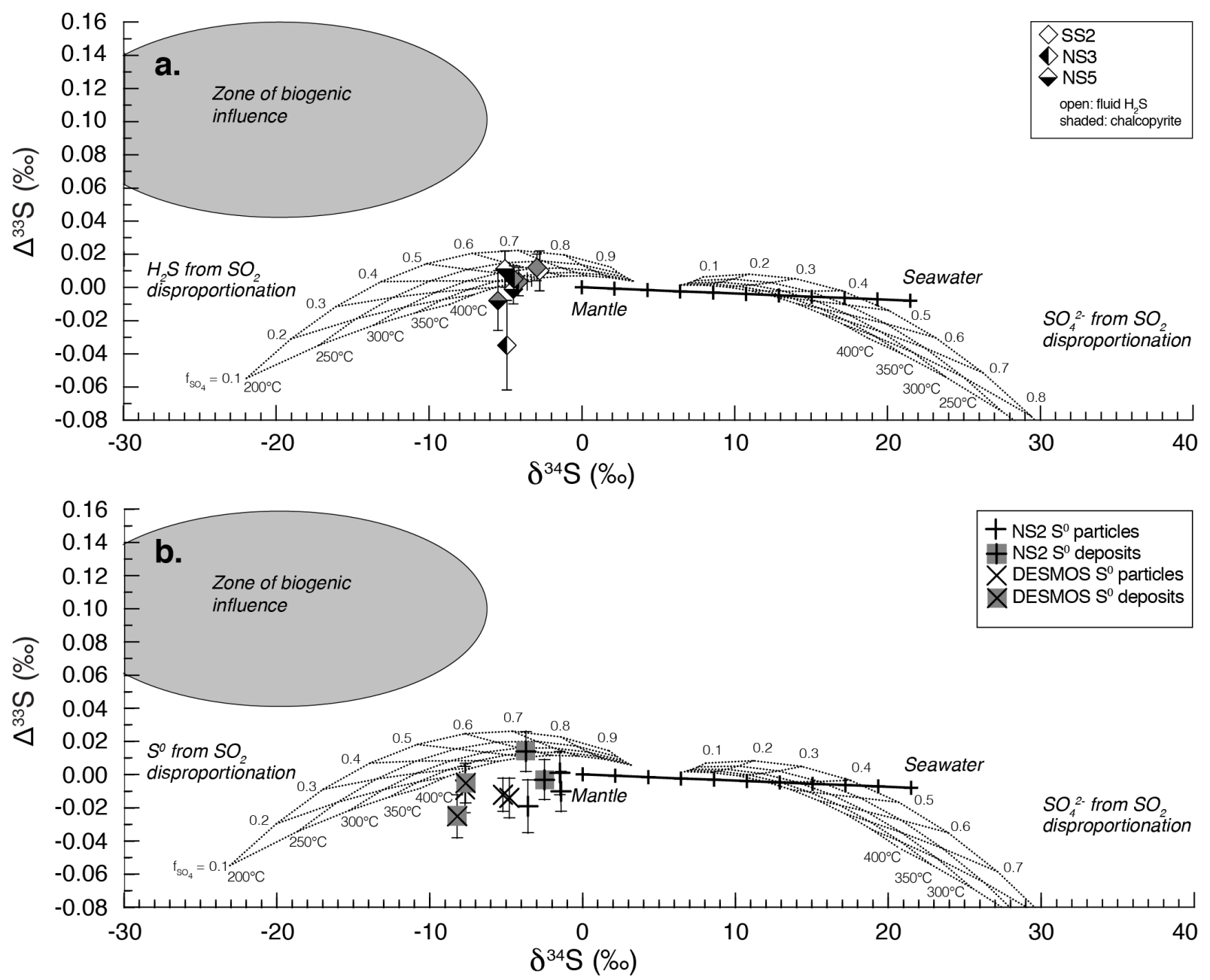

Figure 4. Plots of $\delta^{34} \mathrm{~S}$ versus $\Delta^{33} \mathrm{~S}$ for $\mathrm{H}_{2} \mathrm{~S}$ (open symbols) and chalcopyrite (half-tone symbols) for black smokers at SuSu Knolls (diamonds) (a) and for $\mathrm{S}^{0}$ precipitates and deposits from acidspring fluids at both North $\mathrm{Su}$ (crosses; open symbols are particles filtered from fluids, half-tone are seafloor deposits) and DESMOS Caldera (b) (Xs). In both (a) and (b) the mixing line between mantle sulfur and seawater $\mathrm{SO}_{4}$, is represented by a black line marked with crosses corresponding to relative mass fraction in 0.1 increments. A zone of biogenic influence indicates the elevation in $\Delta^{33} \mathrm{~S}$ observed in biogenic sedimentary pyrite and $\mathrm{S}^{0}$. Meshed fields indicate the equilibrium sulfur isotope compositions of $\mathrm{H}_{2} \mathrm{~S}$ and $\mathrm{SO}_{4}$ (a) and $\mathrm{S}^{0}$ and $\mathrm{SO}_{4}{ }^{2-}$ (b) expected from a magmatic $\mathrm{SO}_{2}$ source (see text). 

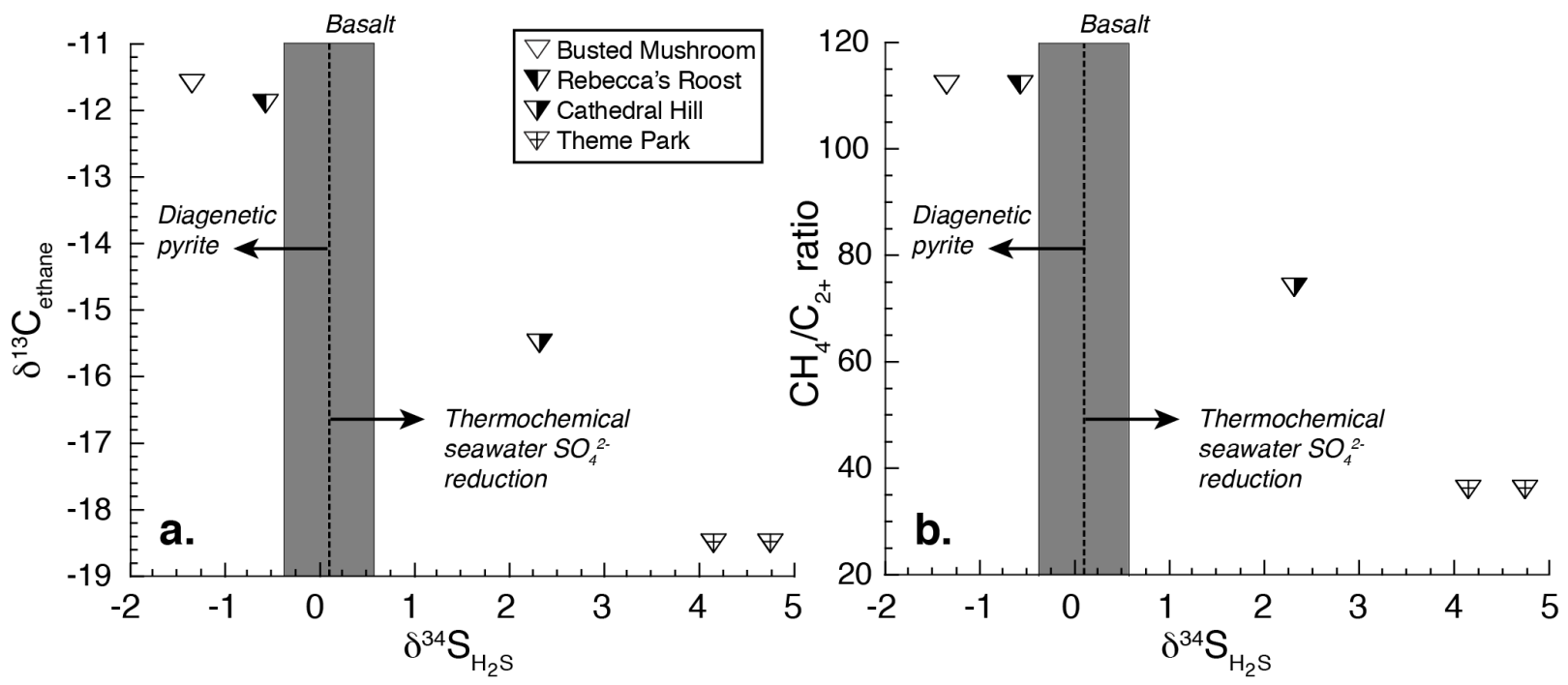

Figure 5. Plot of Guaymas Basin fluid $\delta^{34} \mathrm{~S}_{\mathrm{H}_{2} \mathrm{~S}}$ versus $\delta^{13} \mathrm{C}_{\text {ethane }}$ (a) and versus the ratio of methane to longer chain alkane abundance (b). Basaltic $\delta^{34} \mathrm{~S}$ is represented by a dotted line, with shaded bar showing natural variability. Arrows indicate the relative ${ }^{34} \mathrm{~S}$ depletion or enrichment in fluid $\mathrm{H}_{2} \mathrm{~S}$ that would result following leaching of diagenetic pyrite from sediments or seawater $\mathrm{SO}_{4}$ reduction. 


\section{REFERENCES}

Alt, J.C., Shanks III, W.C., JACKSOn, M.C. (1993) Cycling of sulfur in subduction zones: the geochemistry of sulfur in the Mariana Island Arc and back-arc trough. Earth Planet. Sci. Lett. 119(4), 477-494.

BERNER, R.A. (1964) Distribution and diagenesis of sulfur in some sediments from the Gulf of California. Mar. Geol. 1(2), 117-140.

BinNs, R.A., SCOTT, S.D. (1993) Actively forming polymetallic sulfide deposits associated with felsic volcanic rocks in the eastern Manus Back-Arc Basin, Papua New Guinea. Econ. Geol. 88(8), 2226-2236.

Bluth, G.J., Онмото, H. (1988) Sulfide-sulfate chimneys on the East Pacific Rise, $11^{\circ}$ and $13^{\circ} \mathrm{N}$ latitudes; Part II, Sulfur isotopes. Can. Mineral. 26(3), 505-515.

CAlvert, S.E. (1966) Accumulation of diatomaceous silica in the sediments of the Gulf of California. Geol. Soc. Am. Bull. 77(6), 569-596.

CANFIELD, D.E. (2001) Isotope fractionation by natural populations of sulfate-reducing bacteria. Geochim. Cosmochim. Acta 65(7), 1117-1124.

CAnfield, D.E., Teske A. (1996) Late Proterozoic rise in atmospheric oxygen concentration inferred from phylogenetic and sulphur-isotope studies. Nature 382(6582), 127-132.

Canfield, D.E., Raiswell, R., Westrich, J.T., Reaves, C.M., Berner, R.A. (1986) The use of chromium reduction in the analysis of reduced inorganic sulfur in sediments and shales. Chem. Geol. 54(1-2), 149-155.

Coplen, T.B., Krouse, H.R. (1998) Sulphur isotope data consistency improved. Nature $392(6671), 32$.

CradDOCK, P.R., BACH, W. (2010) Insights to magmatic-hydrothermal processes in the Manus Back-Arc Basin as recorded by anhydrite. Geochim. Cosmochim. Acta 74(19), 5514 5536.

Craddock, P.R., Bach, W., Seewald, J.S., Rouxel, O.J., Reeves, E.P., Tivey, M.K. (2010) Rare earth element abundances in hydrothermal fluids from the Manus Basin, Papua New Guinea: Indicators of sub-seafloor hydrothermal processes in back-arc basins. Geochim. Cosmochim. Acta 74(19), 5494-5513. 
CRuse, A.M., SEewALD, J.S. (2006) Geochemistry of low-molecular weight hydrocarbons in hydrothermal fluids from Middle Valley, northern Juan de Fuca Ridge. Geochim. Cosmochim. Acta 70(8), 2073-2092.

Edmond, J.M., Measures, C., McDuff, R.E., Chan, L.H., Collier, R., Grant, B. (1979) Ridge crest hydrothermal activity and the balances of the major and minor elements in the ocean: The Galapagos data. Earth Planet. Sci. Lett. 46(1), 1-18.

Elderfield, H., Mills, R.A., Rudnicki, M.D. (1993) Geochemical and thermal fluxes, hightemperature venting and diffuse flow from mid-ocean ridge hydrothermal systems: the TAG hydrothermal field, Mid-Atlantic Ridge $26^{\circ}$ N. Geol. Soc. Lond. Spec. Publ. 76, 295-307.

ElDERFIELD, H., Schultz, A. (1996) Mid-ocean ridge hydrothermal fluxes and the chemical composition of the ocean. Annu. Rev. Earth Planet. Sci. 24, 191-224.

Escrig, S., Bézos, A., Goldstein, S.L., Langmuir, C.H., Michael, P.J. (2009) Mantle source variations beneath the Eastern Lau Spreading Center and the nature of subduction components in the Lau basin-Tonga arc system. Geochem. Geophys. Geosys. 10, Q04014, doi:10.1029/2008GC002047.

Farquhar, J., Wu N., CANField, D.E., Oduro, H. (2010) Connections between sulfur cycle evolution, sulfur isotopes, sediments, and base metal sulfide deposits. Econ. Geol. 105(3), $509-533$.

FARQUHAR, J., JOHNSTON, D.T., WING, B.A. (2007) Implications of conservation of mass effects on mass-dependent isotope fractionations: Influence of network structure on sulfur isotope phase space of dissimilatory sulfate reduction. Geochim. Cosmochim. Acta 71(24), 5862-5875.

Farquhar, J., Johnston, D.T., Wing, B.A., Habicht, K.S., CAnfield, D.E., Airieau, S., THIEMENS, M.H. (2003) Multiple sulphur isotopic interpretations of biosynthetic pathways: implications for biological signatures in the sulphur isotope record. Geobiology 1(1), 27-36.

FORREST, J., NEWMAN L. (1977) Silver-110 microgram sulfate analysis for the short time resolution of ambient levels of sulfur aerosol. Anal. Chem. 49(11), 1579-1584. 
Fouquet, Y., von Stackelberg, U., Charlou, J.L., Erzinger, J., Herzig, P.M., Mühe, R., WiEDICKE, M. (1993) Metallogenesis in back-arc environments: the Lau Basin example. Econ. Geol. 88(8), 2154-2181.

Gamo, T., Okamura, K., Charlou, J.L., Urabe, T., Auzende, J.M., Ishibashi, J., Shitashima, K., CHIBA, H. (1997) Acidic and sulfate-rich hydrothermal fluids from the Manus BackArc Basin, Papua New Guinea. Geology 25(2), 139-142.

GaO, X., Thiemens, M.H. (1991) Systematic study of sulfur isotopic composition in iron meteorites and the occurrence of excess ${ }^{33} \mathrm{~S}$ and ${ }^{36} \mathrm{~S}$. Geochim. Cosmochim. Acta 55(9), $2671-2679$.

Gena, K.R., Chiba, H., Mizuta, T., Matsubaya, O. (2006) Hydrogen, oxygen and sulfur isotope studies of seafloor hydrothermal system at the Desmos caldera, Manus Back-Arc Basin, Papua New Guinea: an analogue of terrestrial acid hot crater-lake. Resour. Geol. 56(2), 183-190.

Holland, H. (1965) Some applications of thermochemical data to problems of ore deposits; Part 2, Mineral assemblages and the composition of ore forming fluids. Econ. Geol. 60(6), 1101-1166.

Hrischeva, E., Scott, S.D., Weston, R. (2007) Metalliferous sediments associated with presently forming volcanogenic massive sulfides: The SuSu Knolls hydrothermal field, Eastern Manus Basin, Papua New Guinea. Econ. Geol. 102(1), 55-73.

JAfFRÉs, J.B.D., Shields, G.A., Wallmann, K. (2007) The oxygen isotope evolution of seawater: A critical review of a long-standing controversy and an improved geological water cycle model for the past 3.4 billion years. Earth Sci. Rev. 83(1-2), 83-122.

Johnston, D.T. (2011) Multiple sulfur isotopes and the evolution of Earth's surface sulfur cycle. Earth Sci. Rev. 106(1-2), 161-183.

Johnston, D.T., Wing, B.A., Farquhar, J., Kaufman, A.J., Strauss, H., Lyons, T.W., Kah, L.C., CANFIELD, D.E. (2005) Active microbial sulfur disproportionation in the Mesoproterozoic. Science 310(5753), 1477-1479.

Jørgensen, B.B., ZAWACKI, L.X., JANNASCH, H.W. (1990) Thermophilic bacterial sulfate reduction in deep-sea sediments at the Guaymas Basin hydrothermal vent site (Gulf of California). Deep-Sea Res. I 37(4), 695-710. 
KajIWARA, Y., Krouse, H.R. (1971) Sulfur isotope partitioning in metallic sulfide systems. Can. J. Earth Sci. 8(11), 1397-1408.

Kaplan, I.R., EMERY, K.O., RitTenberG, S.C. (1963) The distribution and isotopic abundance of sulphur in recent marine sediments off southern California. Geochim. Cosmochim. Acta 27, 297-331.

KAPLAN, I.R., RitTEnBERG, S.C. (1964) Microbiological fractionation of sulphur isotopes. $J$. Gen. Microbiol. 34(2), 195-212.

Kerridge, J.F., HAYMOn, R.M., KASTner, M. (1983) Sulfur isotope systematics at the $21^{\circ}$ N site, East Pacific Rise. Earth Planet. Sci. Lett. 66, 91-100.

KIM, J., LEE, I., LEE, K.-Y. (2004) S, Sr, and Pb isotopic systematics of hydrothermal chimney precipitates from the Eastern Manus Basin, western Pacific: Evaluation of magmatic contribution to hydrothermal system. J. Geophys. Res.: Solid Earth 109(B12), B12210, doi:10.1029/2003JB002912.

KIM, J., LEE, K.-Y., KIM, J.-H. (2011) Metal-bearing molten sulfur collected from a submarine volcano: Implications for vapor transport of metals in seafloor hydrothermal systems. Geology 39(4), 351-354.

Kusakabe, M., Komoda, Y., Takano, B., Abiko, T. (2000) Sulfur isotopic effects in the disproportionation reaction of sulfur dioxide in hydrothermal fluids: implications for the $\delta^{34} \mathrm{~S}$ variations of dissolved bisulfate and elemental sulfur from active crater lakes. $J$. Volcanol. Geoth. Res. 97(1-4), 287-307.

LI, Y., LIU, J. (2006) Calculation of sulfur isotope fractionation in sulfides. Geochim. Cosmochim. Acta 70(7), 1789-1795.

Lilley, M.D., ButTerfield, D.A., Olson, E.J., Lupton, J.E., Macko, S.A., McDuff, R.E. (1993) Anomalous $\mathrm{CH}_{4}$ and $\mathrm{NH}_{4}{ }^{+}$concentrations at an unsedimented mid-ocean-ridge hydrothermal system. Nature 364(6432), 45-47.

Lorant, F., Prinzhofer, A., Behar, F. Huc, A.-Y. (1998) Carbon isotopic and molecular constraints on the formation and the expulsion of thermogenic hydrocarbon gases. Chem. Geol. 147, 249-264.

Machel, H.G., Krouse, H.R., SAssen, R. (1995) Products and distinguishing criteria of bacterial and thermochemical sulfate reduction. Appl. Geochem. 10(4), 373-389. 
MacNamara, J., Thode, H.G. (1950) Comparison of the isotopic constitution of terrestrial and meteoritic sulfur. Phys. Rev. 78(3), 307-308.

Martinez, F., TAYloR, B. (2002) Mantle wedge control on back-arc crustal accretion. Nature 416(6879), 417-420.

Mottl, M.J., Seewald, J.S., Wheat, C.G., Tivey, M.K., Michael, P.J., Proskurowski, G., McCollom, T.M., Reeves, E.P., Sharkey, J., You, C.-F., Chan, L.-H., Pichler, T. (2011) Chemistry of hot springs along the Eastern Lau Spreading Center. Geochim. Cosmochim. Acta 75(4), 1013-1038.

Онмото, H., LASAGA, A.C. (1982) Kinetics of reactions between aqueous sulfates and sulfides in hydrothermal systems. Geochim. Cosmochim. Acta 46(10), 1727-1745.

Ono, S., Keller, N.S., Rouxel, O.J., Alt, J.C. (2012) Sulfur-33 constraints on the origin of secondary pyrite in altered oceanic basement. Geochim. Cosmochim. Acta 87, 323-340.

OnO, S., Shanks III, W.C., Rouxel, O.J., Rumble D. (2007) S-33 constraints on the seawater sulfate contribution in modern seafloor hydrothermal vent sulfides. Geochim. Cosmochim. Acta 71(5), 1170-1182.

Ono, S., Wing, B., Johnston, D., FArquhar, J., Rumble, D. (2006) Mass-dependent fractionation of quadruple stable sulfur isotope system as a new tracer of sulfur biogeochemical cycles. Geochim. Cosmochim. Acta 70(9), 2238-2252.

OtAke, T., LAsaga, A.C., Онмото H. (2008) Ab initio calculations for equilibrium fractionations in multiple sulfur isotope systems. Chem. Geol. 249(3-4), 357-376.

Pagé, A., Tivey, M.K., Stakes, D.S., Reysenbach A.-L. (2008) Temporal and spatial archaeal colonization of hydrothermal vent deposits. Environ. Microbiol. 10(4), 874-884.

Peter, J.M., Shanks III, W.C. (1992) Sulfur, carbon, and oxygen isotope variations in submarine hydrothermal deposits of Guaymas Basin, Gulf of California, USA. Geochim. Cosmochim. Acta 56(5), 2025-2040.

Peters, M., Strauss, H., Farquhar, J., Ockert, C., Eickmann, B., Jost, C.L. (2010) Sulfur cycling at the Mid-Atlantic Ridge: A multiple sulfur isotope approach. Chem. Geol. 269(3-4), 180-196.

Peters, M., Strauss, H., Petersen, S., Kummer, N.-A., Thomazo, C. (2011) Hydrothermalism in the Tyrrhenian Sea: Inorganic and microbial sulfur cycling as revealed by geochemical and multiple sulfur isotope data. Chem. Geol. 280(1-2), 217-231. 
ReEs, C.E., Jenkins, W.J., Monster, J. (1978) The sulphur isotopic composition of ocean water sulphate. Geochim. Cosmochim. Acta 42(4), 377-381.

Reeves, E.P., Seewald, J.S., Saccocia, P., Bach, W., Craddock, P.R., Shanks III, W.C., Sylva, S.P., Walsh, E., Pichler, T., Rosner, M. (2011) Geochemistry of hydrothermal fluids from the PACMANUS, Northeast Pual and Vienna Woods hydrothermal fields, Manus Basin, Papua New Guinea. Geochim. Cosmochim. Acta 75(4), 1088-1123.

Rooney, M.A., Claypool, G.E., Moses Chung, H. (1995) Modeling thermogenic gas generation using carbon isotope ratios of natural gas hydrocarbons. Chem. Geol. 126, 219-232.

Rouxel, O., Ono, S., Alt, J., Rumble, D., Ludden, J. (2008) Sulfur isotope evidence for microbial sulfate reduction in altered oceanic basalts at ODP Site 801. Earth Plan. Sci. Lett. 268(1-2), 110-123.

Rouxel, O., Shanks III, W. C., BACH, W., EdWARds, K.J. (2008) Integrated Fe- and S-isotope study of seafloor hydrothermal vents at East Pacific Rise $9-10^{\circ} \mathrm{N}$. Chem. Geol. 252(3-4), $214-227$.

Sakai, H., Des Marais, D.J., Ueda A., Moore, J.G. (1984) Concentrations and isotope ratios of carbon, nitrogen and sulfur in ocean-floor basalts. Geochim. Cosmochim. Acta 48(12), 2433-2441.

SeEWALd, J.S., SeYFried JR., W.E., Shanks III, W.C. (1994) Variations in the chemical and stable isotope composition of carbon and sulfur species during organic-rich sediment alteration: An experimental and theoretical study of hydrothermal activity at Guaymas Basin, Gulf of California. Geochim. Cosmochim. Acta 58(22), 5065-5082.

SeEwald, J.S., SeYfried JR., W.E., ThORnton, E.C. (1990) Organic-rich sediment alteration: An experimental and theoretical study at elevated temperatures and pressures. Appl. Geochem. 5(1-2), 193-209.

Seewald, J.S., DoherTy, K.W., Hammar, T.R., Liberatore, S.P. (2002) A new gas-tight isobaric sampler for hydrothermal fluids. Deep Sea Res. Part I 49(1), 189-196.

SHANKS III, W.C. (2001) Stable isotopes in seafloor hydrothermal systems: vent fluids, hydrothermal deposits, hydrothermal alteration, and microbial processes. In Stable Isotope Geochemistry (eds. J. W. Valley and D. R. Cole), Rev. Min. Geochem., Min. Soc. Amer., Washington, D.C., 43(1), 469-525. 
Shanks III, W.C., Crowe, D.E., Johnson, C. (1998) Sulfur Isotope Analyses Using the Laser Microprobe. In Applications of Microanalytical Techniques to Understanding Mineralizing Processes (eds. M. McKibben, W. C. Shanks III, and W. I. Ridley) Rev. Econ. Geol., Soc. Econ. Geol., Littleton, Colorado, 7, pp. 141-153.

SIM, M.S., BosaK, T., ONO, S. (2011) Large sulfur isotope fractionation does not require disproportionation. Science 333(6038), 74-77.

Sinton, J.M., Ford, L.L., Chappell, B., McCullough, M. T. (2003) Magma genesis and mantle heterogeneity in the Manus Back-Arc Basin, Papua New Guinea. J. Petrol. 44(1), $159-195$.

Staudigel, H., HART, S.R. (1983) Alteration of basaltic glass: Mechanisms and significance for the oceanic crust-seawater budget. Geochim. Cosmochim. Acta 47(3), 337-350.

TAYLOR, B.E. (1986) Magmatic volatiles: Isotopic variation of C, H, and S. Rev. Miner. Geochem. 16, 185-225.

Thode, H.G., Monster, J., Dunford, H.B. (1961) Sulphur isotope geochemistry. Geochim. Cosmochim. Acta 25, 159-174.

ThOrnton, E.C., SEYFrIED JR., W.E. (1987) Reactivity of organic-rich sediment in seawater at $350^{\circ} \mathrm{C}, 500$ bars: Experimental and theoretical constraints and implications for the Guaymas Basin hydrothermal system. Geochim. Cosmochim. Acta 51(7), 1997-2010.

UEDA, A., SAKAI, H. (1984) Sulfur isotope study of quaternary volcanic rocks from the Japanese Islands Arc. Geochim. Cosmochim. Acta 48(9), 1837-1848.

UREY, H.C. (1947) The thermodynamic properties of isotopic substances. J. Chem. Soc., 562581.

VON DAMM, K.L. (1995) Controls on the chemistry and temporal variability of seafloor hydrothermal systems. In Seafloor Hydrothermal Systems: Physical, Chemical, Biological, and Geological Interactions, vol. 91 (eds. S. E. Humphris, R. A. Zierenberg, L. S. Mullineaux and R. E. Thompson). AGU Monograph, American Geophysical Union, pp. 222-247.

Von Damm, K.L., EDMOnd, J.M., Grant, B., MEASURES, C.I. (1985) Chemistry of submarine hydrothermal solutions at $21^{\circ} \mathrm{N}$, East Pacific Rise. Geochim. Cosmochim. Acta 49(11), $2197-2220$. 
WeLhan, J.A., LuPTON, J.E. (1987) Light hydrocarbon gases in Guaymas Basin hydrothermal fluids: Thermogenic versus abiogenic origin. Am. Assoc. Petr. Geol. B. 71(2), 215-223. WOODRUFF, L.G., SHANKS III, W.C. (1988) Sulfur isotope study of chimney minerals and vent fluids from $21^{\circ} \mathrm{N}$, East Pacific Rise: Hydrothermal sulfur sources and disequilibrium sulfate reduction. J. Geophys. Res.: Solid Earth 93(B5), 4562-4572, doi: 10.1029/JB093iB05p04562. 


\section{APPENDIX}

These notes outline three components of the analysis: the basic statistical model, the error model, and inference based on the likelihood.

\subsection{Basic statistical model}

Let $Y_{j k l}$ be the measurement for sample $l$ at vent $k$ of isotope $j$. The basic statistical model is:

$$
Y_{j k l}=\mu_{1 k}+A T_{k}^{-2} I_{2}(j)+\varepsilon_{j k l}
$$

where $\mu_{1 k}$ is the unknown mean for isotope 1 at vent $k$ (Table A1); $A$ is the unknown parameter of interest; $T_{k}$ is temperature at vent $k ; I_{2}(j)$ is a binary indicator taking value 1 if $j=2$ and 0 otherwise; and $\varepsilon_{j k l}$ is an error.

\subsection{Error model}

For a 'single' sample, the error $\varepsilon_{j k l}$ is the sum of a normal measurement error with mean 0 and known variance $\sigma_{j k l}^{2}$ and an independent normal error representing natural variability with mean 0 and unknown variance $\eta_{j}^{2}$ that depends on the type of isotope. The variance of the total error $\varepsilon_{j k l}$ is $\sigma_{j k l}^{2}+\eta_{j}^{2}$. We will treat a 'double' sample as the homogenization of two 'single' samples that is then split and measured twice. It follows that the variance of the total error $\varepsilon_{j k l}$ for a measurement from a 'double' sample is $\sigma_{j k l}^{2}+\eta_{j}^{2} / 2$ and that the covariance between the two measurements from a 'double' sample is $\eta_{j}^{2} / 2$. 


\subsection{Inference about $\beta$}

This model contains 16 unknown regression parameters $A$ and $\mu=\left(\mu_{11} \ldots \mu_{1,15}\right)$ and 2 unknown variance parameters $\eta^{2}=\left(\eta_{1}^{2} \eta_{2}^{2}\right)$. The log likelihood function is:

$$
\log L\left(A, \mu, \eta^{2}\right)=-\frac{1}{2} \log |\Sigma|-\frac{1}{2}(Y-\hat{Y})^{\prime} \Sigma^{-1}(Y-\hat{Y})
$$

where $\Sigma$ is the 42 -by-42 variance matrix of the errors and $(Y-\hat{Y})$ is the vector of length 42 with elements $Y_{j k l}-\left(\mu_{1 j}+A T_{k}^{-2} I_{2}(j)\right)$. It is convenient to base inference about $A$ on the profile log likelihood defined as:

$$
\log L_{\text {prof }}(A)=\log L\left(A, \hat{\mu}(A), \hat{\eta}^{2}(A)\right)
$$

where $\hat{\mu}(A)$ and $\hat{\eta}^{2}(A)$ are the maximum likelihood estimates of $\mu$ and $\eta^{2}$ with $A$ fixed.

Computational efficiency can be gained by noting that, for a fixed value of $\eta^{2}$, the maximum likelihood estimate of $\mu$ can be found by generalized least squares.

The maximum likelihood estimate $\hat{A}$ of $A$ is the value for which $\log L_{\text {prof }}(A)$ is largest and the maximum likelihood estimates of $\mu$ and $\eta^{2}$ are $\hat{\mu}(\hat{A})$ and $\hat{\eta}^{2}(\hat{A})$, respectively. Finally, an approximate $1-\alpha$ confidence interval for $A$ consists of all values satisfying:

$$
2\left(\log L_{\text {prof }}(\hat{A})-\log L_{\text {prof }}(A)\right) \leq \chi_{1}^{2}(\alpha) \quad \text { (4) where }
$$

$\chi_{1}^{2}(\alpha)$ is the upper $\alpha$-quantile of the chi squared distribution with 1 degree of freedom. The maximum likelihood estimate of $A$ is -0.11 with an approximate 0.95 confidence interval of ($0.23,0.01)$. The maximum likelihood estimate of the standard deviations of the non-measurement error for $\mathrm{H}_{2} \mathrm{~S}$ samples $(j=1)$ is 0.71 and is 0.11 
for chalcopyrite samples $(j=2)$.

\subsection{Model sensitivity}

At one vent, Satanic Mills, two replicate analyses of a homogenized 'double' chalcopyrite sample (J2-209-1-R1) are further apart than might be expected from the measurement error variances. The results, however, are insensitive to the exclusion of this double sample. When these two samples are omitted from the model analysis, the overall log likelihood is substantially higher. This reflects the unlikelihood of the results obtained for the double sample - that is, with measurement error variances this small, one would not expect to see such a big difference in measurements from a double sample. However, omitting the double chalcopyrite sample at SM1 only changes the $\mu_{1 k}$ value at this vent from $-0.29 \%$ to $-0.38 \%$. However, when it comes to the model inference about $A$, the exclusion of these data makes no difference to the overall result with the 0.95 confidence for $A$ containing $-0.05 \times 10^{6}$ but not 0.05 $\times 10^{6}$. 


\section{Chapter 6}

\section{Concluding remarks and future research directions}

This thesis has examined the controls on vent fluid organic, inorganic, and volatile geochemistry at two recently discovered hydrothermal vent fields at the ultraslow spreading Mid-Cayman Rise, both of which expand the known range of fluid compositions. This section briefly summarizes the major findings, outstanding questions, and outlines future research directions.

Organic carbon-rich fluids venting at the intermediate temperature Von Damm hydrothermal field present an opportunity to constrain the relative importance of abiotic organic synthesis to fluid budgets, relative to other potential sources of organic species such as microbial production and thermogenic alteration of living or previously living organic material (MCCOllom, 2008). In CHAPTER 2 and CHAPTER 3, the relative timescales and spatial patterns of abiotic organic compound formation from inorganic $\mathrm{CO}_{2}$ are described in detail, and reveal new insights regarding the origins of $\mathrm{CH}_{4}, \Sigma \mathrm{HCOOH}$, and low-molecular weight hydrocarbons in submarine hydrothermal systems.

CHAPTER 2 results demonstrate that $\mathrm{CH}_{4}$ at Von Damm is sourced from leaching of plutonic-hosted volatile-rich crustal inclusions, rather than generated during active reduction of 
$\mathrm{CO}_{2}$ during seawater-derived fluid circulation. Evidence from fluid chemistry strongly implicates the host rock as a source of the hydrocarbons at Von Damm, and perhaps within other hydrothermal systems worldwide. A detailed organic geochemical analysis examining the abundance, speciation, and $\delta^{13} \mathrm{C}$ isotopic characteristics of rocks at the MCR could further reinforce inferences made from fluid chemistry. An extensive collection of dredged gabbroic rocks from the MCR exists in the sample archive at WHOI (BALLARD et al., 1979; STROUP and Fox, 1981). Thus, there remains an opportunity to further examine the abundance and isotopic characteristics of $\mathrm{CH}_{4}$ that has been identified in preliminary Raman spectroscopic analysis of these gabbros (F. Klein, pers. comm). Higher hydrocarbons identified in Von Damm fluids $\left(\mathrm{C}_{2} \mathrm{H}_{6}, \mathrm{C}_{3} \mathrm{H}_{8}, \mathrm{n}-\mathrm{C}_{4} \mathrm{H}_{10}, \mathrm{i}-\mathrm{C}_{4} \mathrm{H}_{10}, \mathrm{C}_{6} \mathrm{H}_{6}\right)$ may also be trapped within gas phase inclusions in these rocks. A study of He abundance and isotope contents in the inclusions would also be useful as a means to constrain the origin of mantle He identified in Von Damm fluids, and determine whether the relative ratios of $\mathrm{He}$ to carbon species match what is observed in the fluids.

Constraining the relative abundances and isotopic nature of volatile species within the gabbros could provide valuable information regarding the extent of variability of hydrocarbons in fluid inclusions at the MCR, their formation mechanisms, and potential links to Von Damm fluid chemistry. Measurements of bulk carbon from MCR gabbros provide an initial estimate of the amount of material needed for abundance and isotopic measurements of $\mathrm{CH}_{4}(\mathrm{KELLEY}$ and FRÜH-GREEN, 1999), and a crushing apparatus similar to that used for noble gas isotopic measurements could be developed to release gases trapped in fluid inclusions (KURZ et al., 1987).

In CHAPTER 2 AND CHAPTER 3, it was shown that the absence of kinetic barriers allows for rapid abiotic synthesis of metastable $\Sigma \mathrm{HCOOH}$ in subsurface mixing zones during circulation 
of submarine hydrothermal fluids at the Von Damm vent field. This finding contrasts with what was seen for the origin of abiotic $\mathrm{CH}_{4}$ at Von Damm, which forms on much longer timescales of thousands to millions of years in fluid inclusions, and is kinetically inhibited from forming during active fluid circulation despite a positive thermodynamic drive. The abundant $\Sigma \mathrm{HCOOH}$ observed in mixed fluids at Von Damm is likely produced by reduction of seawater-derived $\Sigma \mathrm{CO}_{2}$. Greater $\Sigma \mathrm{HCOOH}$ abundances are observed in fluids with the largest degree of ${ }^{13} \mathrm{C}$ enrichment in $\mathrm{\Sigma CO}_{2}$. The source of $\mathrm{\Sigma HCOOH}$ in mixed fluids at Piccard is less clear, due to high background $\Sigma \mathrm{CO}_{2}$ abundances, although an abiotic origin is likely. Determination of $\Sigma \mathrm{HCOOH}{ }^{13} \mathrm{C}$ isotopes in Von Damm and Piccard fluids may reveal whether or not $\Sigma \mathrm{CO}_{2}$ and $\Sigma \mathrm{HCOOH}$ are consistent with isotopic equilibrium. Isotope fractionation factors have not yet been determined for ${ }^{13} \mathrm{C}$ between $\Sigma \mathrm{CO}_{2}$ and $\Sigma \mathrm{HCOOH}$. A theoretical isotope fractionation factor can be derived from characterizing the isotope thermodynamic properties of the compared compounds, and can be calculated using a semiclassical isotope fractionation theory approach, as described by Urey (1947). These results could yield insight into the origin of $\Sigma \mathrm{HCOOH}$ in other reducing natural waters, such as serpentinizing fluids in the Mariana Forearc (HAGGERTY and FISHER, 1992; MotTL et al., 2003) and deep crustal fracture fluids (LIN et al., 2006).

As discussed in CHAPTER 3, questions remain about the lithology of the substrates undergoing fluid/rock reaction in the subsurface underlying the Von Damm vent field. These questions may be addressed by laboratory experiments or thermodynamic reaction-path models designed to react combinations of substrates (e.g. peridotites, gabbros, basalt) with seawater at high temperature and pressure conditions approximating Von Damm reaction conditions. Comparison of experiment or model outputs with the observed fluid chemistry could reveal potential substrate options that could generate Von Damm fluid chemistries. An approach 
analogous to that of ALLEN AND SEYFRIED (2003) and SEYFRIED et al. (2011) that combines experiments, models, and in situ $\mathrm{pH}$ measurements to account for the composition of hydrothermal fluids at the Rainbow vent field could be used for the Von Damm system.

In CHAPTER 4, it was shown that high temperature black smoker fluids emanating from Piccard, the world's deepest vent field, contain $\mathrm{H}_{2}$ abundances that exceed those observed at ultramafic-influenced hydrothermal systems. These $\mathrm{H}_{2}$ abundances are attributed to fluid/rock reaction that occurs at higher temperatures than at other basalt-hosted ridge-crest hydrothermal systems due to higher pressure conditions in the deep MCR.

An alternative possible means of generating the high fluid $\mathrm{H}_{2}$ abundances observed at Piccard is from ultramafic water/rock reaction during serpentinization of olivine-rich rock. Although there is no other indication of an ultramafic influence at Piccard, analysis of dissolved B contents of the fluids may provide evidence to further strengthen the current interpretation of high temperature basalt/water reaction. Serpentinization results in the uptake of B into secondary minerals, as has been shown in field studies of serpentine, chlorite, and amphibole alteration phases that are enriched in B by several orders of magnitude relative to unaltered mantle (BonATTi et al., 1984; SAVOV et al., 2007; THOMPSON and MELSON, 1970), as well as in hydrothermal seawater-peridotite laboratory experiments (SEYFRIED and DIBBLE, 1980). Although the abundant seafloor basalt outcrops and axial location of the vent field support reaction with basaltic substrate as the dominant control on Piccard fluid chemistry, determination of fluid B abundance, and comparison with Von Damm, Lost City (Foustoukos et al., 2008), and Rainbow fluid B contents (SEYFRIED et al., 2012), could identify a possible ultramafic influence at Piccard. The nature of water/rock reaction at Piccard could also be further examined 
by examining $\mathrm{H}_{2}$ production in water/rock reaction experiments conducted at higher temperatures than previous efforts, which are usually run at temperatures $\leq 400^{\circ} \mathrm{C}$.

The origin of $\mathrm{CH}_{4}$ and $\mathrm{C}_{2+}$ hydrocarbons in the Von Damm system is examined in CHAPTER 2 and CHAPTER 3 by coupling observations of inorganic fluid chemistry with carbon species abundance and $\delta^{13} \mathrm{C}$ isotope measurements. $\mathrm{CH}_{4}$ and $\mathrm{C}_{2+}$ hydrocarbons in Von Damm source fluids are thought to originate in fluid inclusions at temperatures of $\sim 350^{\circ} \mathrm{C}$. At Piccard, endmember fluid $\mathrm{CH}_{4}$ is potentially of mantle-derived origin, however the specific nature of its formation remains less clear, i.e. whether it is leached from basalt or generated by direct degassing of magmatic volatiles. In addition, high-temperature fluid $\mathrm{CH}_{4}$ contents at Piccard may be partially derived from thermogensis of dissolved organic carbon that is present in circulating seawater. The study of multiply substituted isotopologues of $\mathrm{CH}_{4}$, or 'clumping,' to elucidate $\mathrm{CH}_{4}$ formation temperatures is an emerging geochemical tool that would be useful to apply in both the Von Damm and Piccard systems (EILER et al., 2014; STOLPER et al., 2014). Clumped $\mathrm{CH}_{4}$ analysis would be able to discern between $350^{\circ} \mathrm{C}$ and higher temperature formation environments to identify controls on hydrocarbon formation. Clumped $\mathrm{CH}_{4}$ measurements could be performed using existing techniques on $\mathrm{CH}_{4}$ in Von Damm fluids and collected from crushed rock samples, as suggested earlier. The Piccard vent field contains lower $\mathrm{CH}_{4}$ abundances than Von Damm, therefore greater fluid and rock volumes would be required.

In Chapter 5, sulfur isotopes in vent fluid $\mathrm{H}_{2} \mathrm{~S}$ and hydrothermal deposits at a sedimented and unsedimented mid-ocean ridge and two back-arc systems were examined to constrain sulfur sources and the isotope systematics of precipitation processes. Inclusion of the minor ${ }^{33} \mathrm{~S}$ isotope in hydrothermal vent sulfur isotope studies provides additional information that differentiates between ${ }^{34}$ S-depleted sediment and magmatic sulfur sources that would otherwise be 
indistinguishable based on $\delta^{34} \mathrm{~S}$ signatures alone. Outstanding questions remain about the relative importance of abiotic, thermogenic versus microbially mediated $\mathrm{SO}_{4}$ reduction in sedimented systems, however. Multiple sulfur isotopic characterization of other inputs to hydrothermal fluids circulating through the sedimented Guaymas hydrothermal system, such as bulk sediments, diagenetic pyrite, and $\mathrm{SO}_{4}$-containing porewater would be useful to address this question. The CHAPTER 5 study focused on chalcopyrite chimney linings within the inner 1-2 $\mathrm{mm}$ of chimney conduits in order to examine the direct effects of precipitation, however interesting disequilibria in $\delta^{34} \mathrm{~S}$ and $\Delta^{33} \mathrm{~S}$ have been shown to occur in pyrite and marcasite (ONO et al., 2007). Multiple sulfur isotope studies of a transect across the wall of a multi-phase chimney lining containing inter-grown pyrite and chalcopyrite would provide interesting insights about longer term chimney evolution. 


\section{REFERENCES}

Allen, D.E., Seyfried, J., W E (2003) Compositional controls on vent fluids from ultramafichosted hydrothermal systems at mid-ocean ridges: An experimental study at $400^{\circ} \mathrm{C}, 500$ bars. Geochimica et Cosmochimica Acta 67, 1531-1542.

Ballard, R.D., Bryan, W.B., Davis, K., DE Boer, J., DeLong, S., Dick, H., EMERY, K.O., Fox, P.J., Hempton, M., Malcolm, F., Melson, W.G., Spydell, K., Stroup, J.B., ThOMPSON, G., Wright, R., UCHUPI, E. (1979) Geological and geophysical investigation of the Mid-Cayman Rise spreading center: Initial results and observations, in: Talwani, M., Harrison, C.G., Hayes, D.E. (Eds.), Deep Drilling Results in the Atlantic Ocean: Ocean Crust. American Geophysical Union, Washington, D.C., pp. 66-93.

Bonatti, E., LAWrence, J.R., Morandi, N. (1984) Serpentinization of oceanic peridotites: temperature dependence of mineralogy and boron content. Earth and Planetary Science Letters 70, 88-94.

Eiler, J.M., Bergquist, B., Bourg, I., Cartigny, P., Farquhar, J., Gagnon, A., Guo, W., Halevy, I., Hofmann, A., Larson, T.E., Levin, N., Schauble, E.A., Stolper, D. (2014) Frontiers of stable isotope geoscience. Chemical Geology 372, 119-143.

Foustoukos, D.I., SAVOV, I.P., JANECKY, D.R. (2008) Chemical and isotopic constraints on water/rock interactions at the Lost City hydrothermal field, $30^{\circ} \mathrm{N}$ Mid-Atlantic Ridge. Geochimica et Cosmochimica Acta 72, 5457-5474.

HagGerty, J.A., Fisher, J.B. (1992) Short-chain organic acids in interstitial waters from Mariana and Bonin forearc serpentines: Leg 125. Proceedings of the Ocean Drilling Program, Scientific Results 125, 387-395.

Kelley, D.S., FrÜH-GreEn, G.L. (1999) Abiogenic methane in deep-seated mid-ocean ridge environments: Insights from stable isotope analyses. Journal of Geophysical Research 104, 10439-10410-10460.

KurZ, M.D., Gurney, J.J., Jenkins, W.J., LotT, I., DeMPSEY E (1987) Helium isotopic variability within single diamonds from the Orapa kimberlite pipe. Earth and Planetary Science Letters 86, 57-68.

Lin, L.H., Wang, P.L., Rumble, D., Lippmann-Pipke, J., Boice, E., Pratt, L.M., Lollar, B.S., Brodie, E.L., Hazen, T.C., Andersen, G.L., DeSantis, T.Z., Moser, D.P., Kershaw, 
D., OnstotT, T.C. (2006) Long-Term Sustainability of a High-Energy, Low-Diversity Crustal Biome. Science 314, 479-482.

MCColLOM, T. (2008) Observational, experimental, and theoretical constraints on carbon cycling in mid-ocean ridge hydrothermal systems, in: Lowell, R., Seewald, J., Metaxas, A., Perfit, M. (Eds.), Magma to Microbe: Modeling Hydrothermal Processes at Oceanic Spreading Centers. AGU Geophysical Monograph, Washington, D.C., pp. 193-213.

Mottl, M.J., Komor, S.C., Fryer, P., Moyer, C.L. (2003) Deep-slab fluids fuel extremophilic Archaeaon a Mariana forearc serpentinite mud volcano: Ocean Drilling Program Leg 195. Geochemistry Geophysics Geosystems 4, n/a-n/a.

Ono, S., Shanks, W.C., III, Rouxel, O., Rumble, D. (2007) S-33 constraints on the seawater sulfate contribution in modern seafloor hydrothermal vent sulfides. Geochimica et Cosmochimica Acta 71, 1170-1182.

SAvov, I.P., RYAn, J.G., D’ANTONIO, M., Fryer, P. (2007) Shallow slab fluid release across and along the Mariana arc-basin system: Insights from geochemistry of serpentinized peridotites from the Mariana fore arc. Journal of Geophysical Research: Solid Earth (1978-2012) 112.

Seyfried, J., W E, DibBle, J., W E (1980) Seawater-peridotite interaction at $300^{\circ} \mathrm{C}$ and 500 bars: implications for the origin of oceanic serpentinites. Geochimica et Cosmochimica Acta 44, 309-321.

Seyfried, J., W E, Pester, N.J., Ding, K. (2012) Ultramafic-hosted Hydrothermal Systems at Mid-Ocean Ridges: Serpentinization, Chloritization and Geochemical Controls on MassTransfer Processes, American Geophysical Union Fall Meeting, San Francisco, CA.

Seyfried JR, W.E., Pester, N.J., Ding, K., Rough, M. (2011) Vent fluid chemistry of the Rainbow hydrothermal system ( $\left.36^{\circ} \mathrm{N}, \mathrm{MAR}\right)$ : Phase equilibria and in situ $\mathrm{pH}$ controls on subseafloor alteration processes. Geochimica et Cosmochimica Acta 75, 1574-1593.

Stolper, D.A., Lawson, M., Davis, C.L., Ferreira, A.A., Neto, E.V.S., Ellis, G.S., Lewan, M.D., Martini, A.M., TAng, Y., Schoell, M., Sessions, A.L., Eiler, J.M. (2014) Formation temperatures of thermogenic and biogenic methane. Science 344, 1500-1503. Stroup, J., Fox, P. (1981) Geologic Investigations in the Cayman Trough: Evidence for Thin Oceanic-Crust Along the Mid-Cayman Rise. Journal of Geology 89, 395-420. 
Thompson, G., Melson, W.G. (1970) Boron contents of serpentinites and metabasalts in the oceanic crust: implications for the boron cycle in the oceans. Earth and Planetary Science Letters 8, 61-65. 